University of New Hampshire

University of New Hampshire Scholars' Repository

Spring 1994

\title{
Islands of Deutschtum: German Americans in Manchester, New Hampshire and Lawrence, Massachusetts, 1870-1942
}

Robert Paul McCaffery

University of New Hampshire, Durham

Follow this and additional works at: https://scholars.unh.edu/dissertation

\section{Recommended Citation}

McCaffery, Robert Paul, "Islands of Deutschtum: German Americans in Manchester, New Hampshire and Lawrence, Massachusetts, 1870-1942" (1994). Doctoral Dissertations. 1790.

https://scholars.unh.edu/dissertation/1790

This Dissertation is brought to you for free and open access by the Student Scholarship at University of New Hampshire Scholars' Repository. It has been accepted for inclusion in Doctoral Dissertations by an authorized administrator of University of New Hampshire Scholars' Repository. For more information, please contact Scholarly.Communication@unh.edu. 


\section{INFORMATION TO USERS}

This manuscript has been reproduced from the microfilm master. UMI films the text directly from the original or copy submitted. Tnus, some thesis and dissertation copies are in typewriter face, while others may be from any type of computer prizter.

The quality of this reproduction is dependent upon the quality of the copy submitted. Broken or indistinct print, colored or poor quality illustrations and photographs, print bleedthrough, substandard margins, and improper alignment can adversely affect reproduction.

In the unlikely. event that the author did not send UMI a complete manuscript and there are missing pages, these will be noted. Also, if unauthorized copyright material had to be removed, a note will indicate the deletion.

Oversize materials (e.g., maps, drawings, charts) are reproduced by sectioning the original, beginning at the upper left-hand corner and continuing from left to right in equal sections with small overlaps. Each original is also photographed in one exposure and is included in reduced form at the back of the book.

Photographs included in the original manuscript have been reproduced xerographically in this copy. Higher quality $6^{\prime \prime} \times 9^{\prime \prime}$ black and whire photographic printi are available for any photographs or illustrations appearing in this copy for an additional charge. Contact UMI directly to order.

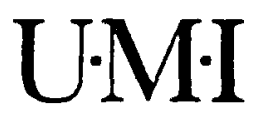

University Microfilms Intematıona!

A Bell \& Howell Information Company

300 North Zeeb Road. Ann Arbor. Ml 48106-1346 USA

$313: 761-4700 \quad 800: 521-0600$ 
Order Number 9506425

Islands of Deutschtum: German Americans in Manchester, New Hampshire and Lawrence, Massachusetts, 1870-1942

McCaffery, Robert Paul, Ph.D.

University of New Hampshire, 1994

Copyright (C)1994 by McCaffery, Robert Paul. All rights reserved.

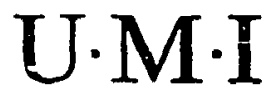

300 N. Zeeb Rd.

Ann Arbor, MI 48106

Reproduced with permission of the copyright owner. Further reproduction prohibited without permission. 


\section{ISLANDS OF DEUTSCHTUM:}

GERMAN-AMERICANS IN

MANCHESTER, NEW HAMPSHIRE AND LAWRENCE, MASSACHUSETTS,

$1870-1942$

BY

ROBERT PAUL MCCAFFERY

B.S.Ed., Duquesne University, 1967

M.A., Duquesne University, 1969

M.B.A., University of New Hampshire, 1980

DISSERTATION

Submitted to the University of New Hampshire
in Partial Fulfillment of
the Requirements for the Degree of
Doctor of Philosophy
in
History

May, 1994 


\section{ALL RIGATS RESERVED}

C 1994

Robert P. McCaffery 
This dissertation has been examined and approved.
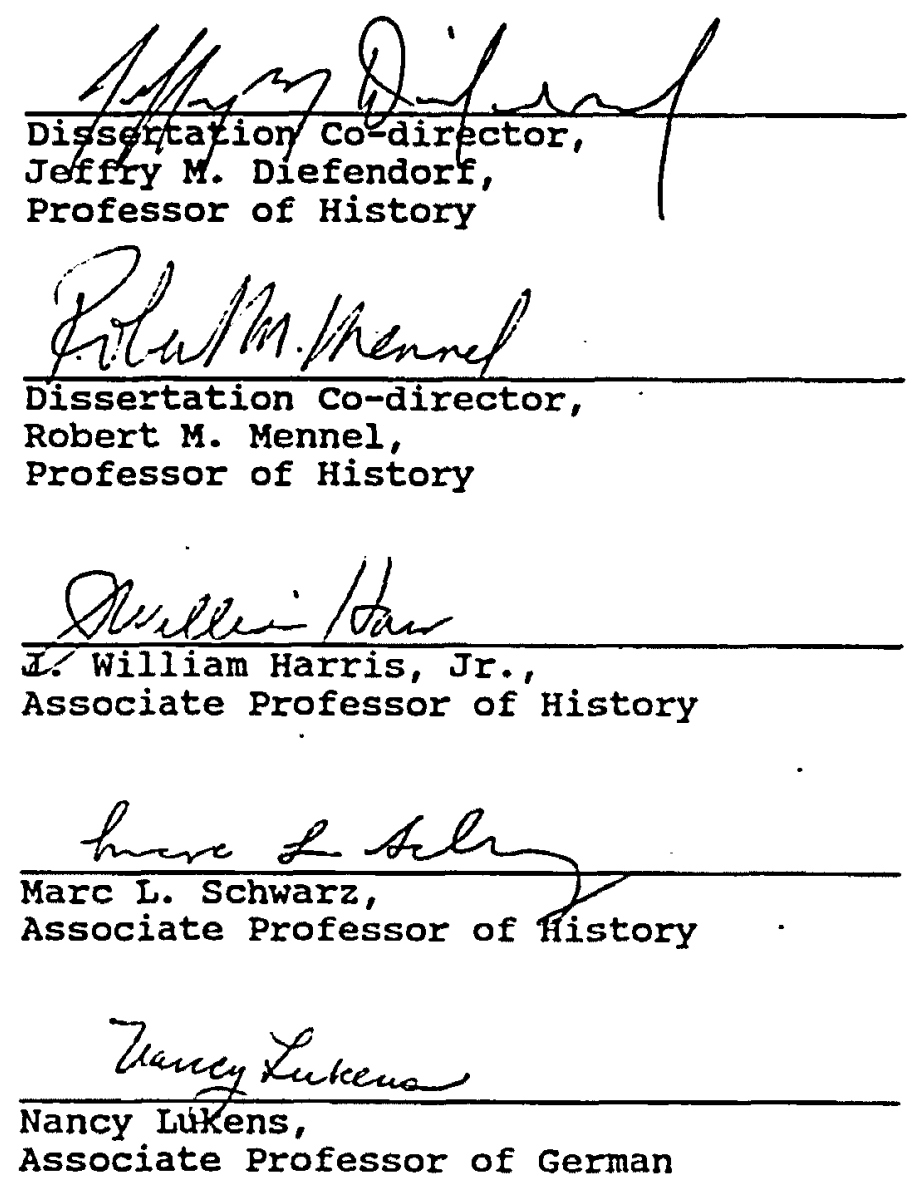

$$
\frac{\text { Cpsil 20,1994 }}{\text { Date }}
$$




\section{ACKNOWLEDGMENTS}

This dissertation could not have been completed without the assistance and support of a great many people who merit acknowledgment and thanks.

First and foremost are the members of my committee. Co-director Robert Mennel encouraged the development of this project and assisted me in numerous ways. He directed and guided me through the historiography of immigration and assimilation. His thoughtful crjtique of my early drafts led to many important improvements and his advice and direction kept me focused on the main issues. Co-director Jeffry Diefendorf also assisted in various ways. Both his contacts at the German Historical Institute, and guidance regarding research in Germany were most beneficial. His careful criticism and evaluation of my work also helped me to improve it. It was in a seminar with William Harris that I first researched Germans in Manchester and discovered the possibilities for further research. Since then his insights on urban and social history have helped in my analysis. Marc Schwarz stressed the importance of the middle class and provided needed encouragement. Nancy Lukens assisted me with the German language and an understanding of German clubs in the United states.

The staff of the James Duncan Philips Library of the Peabody Essex Museum, Salem, MA, deserve special praise. iv 
Library Director William La Moy's knowledge of Essex County and the collections of the institute aided me in my research. Nancy Heywood went out of her way to assist me in obtaining photographic reproductions, and working wonders when one photo went astray in the laboratory, as well as with several other aspects of the project. Jane Ward and Mary Fabiszewski expedited my request for materials and aided my research in a number of ways.

Likewise, the staff of the Immigrant City Archives, Lawrence, MA deserves exceptional praise and thanks. Archive Director, Eartha Dengler, with her knowledge of German, the collections, the city, and resources in the city helped me tremendously. Perhaps no one knows more about Lawrence than, Research Consultant, Ken Skulski who willingly shared his knowledge which provided many insights and avenues for research. And, his good cheer in obtaining materials and in giving information and assistance was most appreciated. Mary Armitage's personal knowledge of Lawrence and its people helped solve a number of problems.

In Manchester, several persons merit acknowledgment. Elizabeth Lessard, Librarian of the Manchester Historic Association, deserves particular thanks. Her knowledge of Manchester was invaluable and in particular her incomparable knowledge of the Amoskeag Records helped me understand that company and textile production. Cindy o'Niel of the Manchester Room of the Manchester Public Library gave me several good leads and suggestions for further research. 
Brother Malachy McCarthy, Archivist of St. Anselm College, arranged accesses to archives of the college and the records of St. Raphael's. Pastor Richard Rhode and the elders of the First Presbyterian Church gave me access to the records and minutes of the church.

In Germany, special thanks go to Falk HUppner who assisted me greatly in many ways, especially during my visit to Leipzig in 1992. In addition he gave invaluable assistance in attempting to locate materials related to saxon emigration in Various archives in Saxony. Also, Gerhard wiesinger unhesitatingly shared his knowledge about saxon emigration to New England.

I am indebted to the individuals who permitted me to interview them throughout the course of this project. Their willingness to welcome a stranger to their homes, to give of their time, and to patiently answer questions is especially appreciated. In Manchester all questions about Germans are referred to Madge Sandmann. Madge has proven to be most kind, knowledgeable, and willing to direct me to many other individuals who, in turn, provided information. She graciously met me a number of times and answered my notes or telephone calls. The Emmert family in Lawrence is a gold mine of information, and they have gladly shared it with me. Finally, I want to thank my wife, Jane, for here understanding and support and my children Tim and Katie for their understanding.

$\mathbf{v i}$ 
TABLE OF CONTENTS

ACKNOWLEDGMENTS......................... iv

IIST OF TABLES.......................... viii

LIST OF MAPS AND ILLUSTRATIONS................ ix

ABSTRACT ................................ $x$

INTRODUCTION............................. 1

CHAPTER I PATTERNS OF GERMAN SETTLEMENT IN THE U.S AND

GERMANS IN NEW ENGLAND............ 21

CHAPTER II GERMANS IN AMERICAN CITIES......... 50

CHAPTER III TEXTILE CITIES:

MANCHESTER AND LAWRENCE........... 99

CHAPTER IV SAXONY IN THE NINETEENTH CENTURY:

FACTORS LEADING TO EMIGRATION........ 118

CHAPTER V ESTABLISHMENT AND EARLY GROWTH OF

GERMAN-AMERICAN COMMUNITIES IN

MANCHESTER

AND LAWRENCE, $1870-1900 \ldots \ldots \ldots \ldots \ldots \ldots 143$

CHAPTER VI HIGH HOPES OF DEUTSCHTUM:

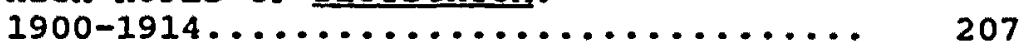

CHAPTER VII REALITIES, 1914-1920: WORLD WAR I AND

THE LOCAL SITUATION .............. 254

CHAPTER VIII BETWEEN THE WORLD WARS:
RE-EMERGENCE, REVIVAL AND SLOW EROSION OF

RE-EMERGENCE, REVIVAL AND SLOW EROSION OF
DEUTSCHTUM, AND A NEW CHALLENGE...... 308

CHAPTER IX END OF DEUTSCHTUM: WORLD WAR II

AND ASSIMILATION............... 359

CONCLUSION $\quad \ldots \ldots \ldots \ldots \ldots \ldots \ldots \ldots \ldots \ldots \ldots \ldots \ldots \ldots \ldots$

APPENDIX MAPS AND ILLUSTRATIONS........... 387

BIBLIOGRAPHY .......................... 400

vii

Reproduced with permission of the copyright owner. Further reproduction prohibited without permission. 
TABLE 4.1 NUMBER OF EMIGRANTS TO U.S FROM SAXONY..... 127

TABLE 4.2 COMPARISON OF SAXON EMIGRATION TO

GERMAN EMIGRATION.................. 128

TABLE 5.1 GERMAN POPULATION OF

MANCHESTER AND LAWRENCE............... 146

TABLE 5.2 TOTAL GERMAN-AMERICANS.............. 146

TABLE 5.3 ORIGING OF GERMAN IMMIGRANTS BY

PROVINCE........................... 151

TABLE 5.4 GERMAN BIRTHPLACES,

MANCHESTER AND LAWRENCE............... 153

TABLE 5.5. ANZEIGER UND POST

CIRCULATION FIGURES.................. 192

TABLE 8.1 ATTENDANCE AT THE

GERMAN LANGUAGE SCHOOLS............... 325

TABLE 8.2 INTERMARRIAGES IN MANCHESTER........... 329

TABLE 9.1 POPULATION SHIFTS, 1920-1960.......... 370 


\section{IIST OF}

MAPS AND ILLUSTRATIONS

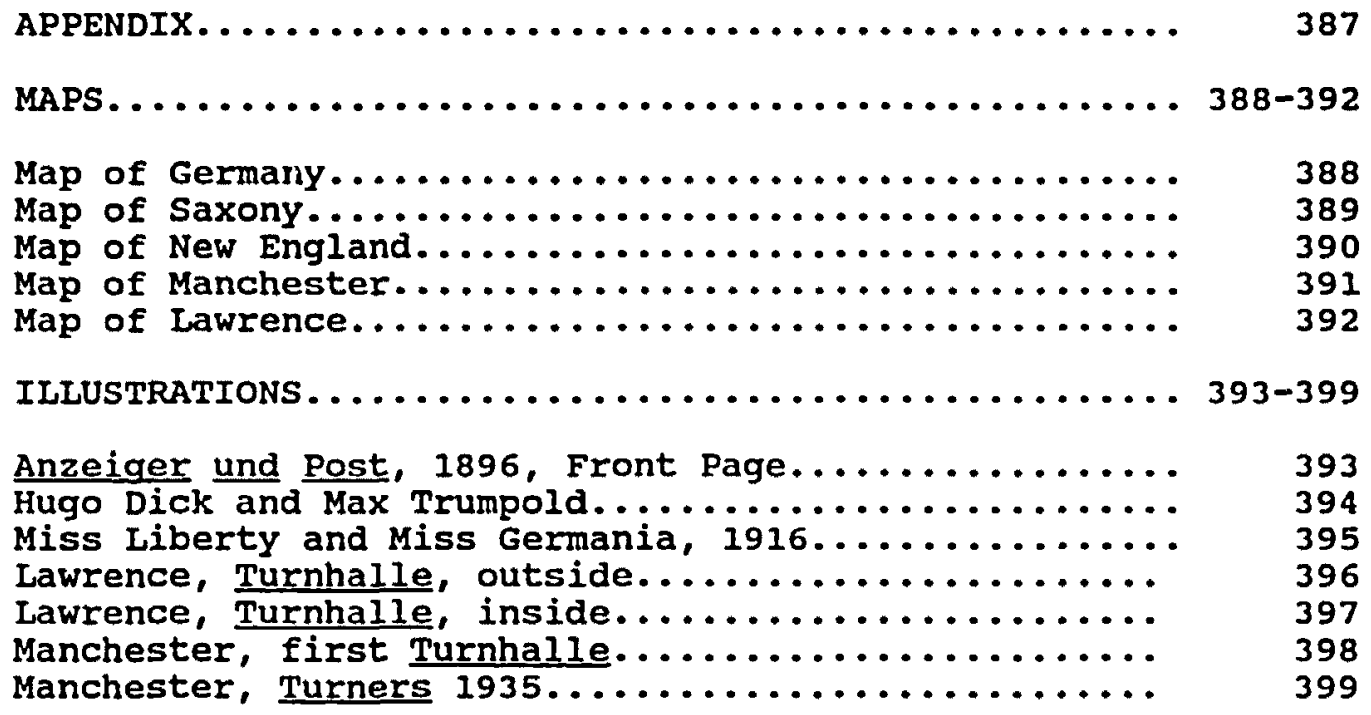




\section{ISIAANDS OF DEUTSCHTUM:}

GERMAN-AMERICANS

IN MANCHESTER, NEW HAMPSHIRE AND LAWRENCE, MASSACHUSETTS, 1870-1942

by

Robert Paul McCaffery

University of New Hampshire, May, 1994

The history of the German-American communities of Manchester, New Hampshire and Lawrence, Massachusetts raises several important issues about German immigration to the United states. Comprising only a small percentage of the population of the two cities German immigrants founded a distinctive culture--islands of Deutschtum--as vibrant as those in the "German belt" of the Midwest. The historiography has generally concluded that German-Americans could not unite in common cause, and that world War I ended German culture in America. However, not only did Germans in Manchester and Lawrence unite, but they maintained Deutschtum through world War I into World War II.

Several factors led to the longevity of these islands of Deutschtuin. Atypical of the majority of German immigrants, one-third of the Germans in Manchester and Lawrence came from Saxony and another seventeen percent came from silesia. America's pre-eminent textile cities attracted textile workers from the small towns of saxony and silesia. Many were acquainted or related to each other, and bonds of family 
and province existed. The small size of the German immigrant community also helped it survive. The immigrants and leaders knew each other, and first-generation leaders remained active into the 1920 s and 1930s. Members of the second-generation continued Deutschtum into the 1940s. A family owned Germanlanguage newspaper supported their efforts from 1883 to 1942. The ability of German Protestants, Catholics, and Vereinsdeutschen to put aside old world animosities and unite in common causes helped preserve ethnicity. German Presbyterian churches and their members played influential roles in Deutschtum in Manchester and Lawrence. The Lutheran denomination, pre-eminent elsewhere in German-American communities, was small or nonexistent, and German Catholic parishes also played less important roles.

During World War I, German-Americans in the two cities maintained active and public expressions of Deutschtum, mostly unthreatened by the larger community. Paradoxically, although German culture proudly continued between the wars, the larger and dominant American culture slowly engulfed it. The shock of World War II submerged German identity, and migration out of the cities after the war finally ended the German enclaves and doomed German ethnicity. 
INTRODUCTION

The population of Northern New England is usually considered to be predominately of English origin, with significant nineteenth century additions of Irish and French Canadians. Germans, on the other hand are perceived to have settled mostly in the Middle Atlantic and Midwestern states, and Italians resided in east coast cities. Although not untrue, these generalizations do not reflect the true ethnic diversity of New England which included Germans among others. Much as seeds are blown across a vast ocean to an island where they land, take root, grow and flourish, but may be overgrown by the more predominant vegetation, the seeds of Deutschtum $^{1}$ were planted, took root, grew and flourished, but were eventually overtaken by the more prominant American culture.

This study examines the German-American communities in Manchester, New Hampshire and Lawrence, Massachusetts. The two cities and their German-American communities are linked together by a number of factors. At the end of the nineteenth century both cities were among the world's greatest textile production centers, and Germans settled in them seeking employment in the textile mills. Not only were most from the same towns in Germany, they were often related. The two communities were also united from 1896 to 1942 through a German language newspaper, the Anzeiger und Post. 
The story of the German-Americans and their enclaves in these textile cities is little known and being lost. Their history both confirms and challenges accepted wisdom about Germans in America.

From the sixteenth through the nineteenth centuries, individuals and families emigrated from Germany for economic or political reasons. 2 up until the middle of the nineteenth century the majority of emigrants left southwestern Germany. In the last third of the nineteenth century the majority of emigrants left northeastern Germany. ${ }^{3}$ scholars have clearly recognized and documented these regional patterns of emigration. However, as will be shown, more than the majority of immigrants to Manchester and Lawrence came from a specific region in southeastern Germany. over one-third came from the Kingdom of saxony, mainly the smaller towns; almost seventeen percent came from Silesia; and fifteen percent from Bavaria, especially from the region near Hof. ${ }^{4}$ Journeying from Hof in Bavaria through Dresden in Saxony to Breslau in silesia, the distance traveled is about 255 miles. This route would take one near many of the small towns from which the emigrants came. Between 1870 and 1890 displaced textile workers transferred job skills from Germany to the textile mills in Manchester and Lawrence. Strong evidence of chain migration exists. Once settled in the textile cities they helped relatives to emigrate and find work in the mills. 
The history of the Germans in America is quite often considered to be the history of total assimilation. Weiting in 1928, H.L. Mencken, himself a German-American, concluded "the children of the German-American are totally American. only the smallest number of them can speak a minimum of German. The melting pot has devoured them, as no other group, not even the Irish." 5 seventy-seven years earlier (1851) F.W. Bogen in his advice book wrote, "We are half Germans and half Americans... for we live no more in the center of German life, and yet we have dissolved the bands that bound us to the old fatherland; and, at the same time, we are not yet real Americans." 6 slightly more than a hundred years later Nathan Glazer and Daniel Patrick Moynihan had concluded that the "Germans as an ethnic group had disappeared."7 Richard 0 'Connor referred to them as the "great white whale," 8 the unseen but large creature known to be under the surface.

The disappearance is remarkable, for in the nineteenth century the German-Americans were the largest minority group in America. Every major city, and many smaller ones also, had a "little Germany" or "over the Rhine" district. In these districts there was a multitude of German shops, clubs, music halls, taverns, and churches. German was the dominant language of the neighborhood. 9 In the early years of the twentieth century immigrant arrivals shifted away from Germany to southern and eastern Europe, leading to a decline 
in the relative strength of German-Americans. Perceiving this, a National German-American Alliance formed to promote German goals, and even the small German communities of Manchester and Lawrence joined the Alliance.

Despite their numbers, and despite the Alliance, and unlike many immigrant groups, Germans never united as a powerful ethnic block. Religious disputes brought from the old country prevented them from uniting in the new. The two strongest denominations, Catholics and Lutherans, could not come together; and the Free Thinkers distrusted and shunned them both. 10 These divisions ran so deep that GermanAmericans could neither unite to fend off attacks engendered by World War I, nor elect German candidates for political office. 11 However, as we shall see, in Manchester and Lawrence German-Americans could unite in common cause. German Presbyterians, Catholics, and Free Thinkers united in 1916 and again after the war to raise money for Germany. Both the small size of the German-American communities and the small sizes of the cities contributed to this unity. Moreover, it is often assumed that the anti-German hysteria during World War I completely destroyed GermanAmerican ethnicity. Not only did sauerkraut become "Liberty Cabbage," but German-Americans ate their sauerkraut behind closed doors and drawn drapes. German-Americans practiced their culture and celebrated their ethnicity, if it survived at all, in private. 12 However, some historians have shown that Deutschtum survived the First World War I in Chicago, 
Cincinnati, and Baltimore. Furthermore, the Yorkville section of New York existed as a distinctive German community into the mid-1950s. ${ }^{13}$ It is suspected that, on closer examination, it could be shown that German ethnicity continued, perhaps weakened, at least to World war II in many American cities. As will be shown, World War I did not destroy Deutschtum in Manchester and Lawrence. In these two cities, German-American activities continued during World war I, through the twenties and thirties, but met their final challenge during and after World War II. In some cities the anti-German hysteria of World War I may have been a convenient cover for socal political battles. For instance, in Cincinnati where German-Americans had gained political control, scholars have suggested that the Anglo-Americans who had lost political influence used patriotism and anti-German feelings to regain political control. ${ }^{14}$ In Manchester and Lawrence, although German-Americans were elected to a number of offices, ${ }^{15}$ they did not challenge the political control of the Anglo-Americans and Irish in Manchester and the Irish in Lawrence. Furthermore, the local English language newspapers did not fan political issues or attack the German-American residents of their cities. In neither city was anti-German hysteria prevalent.

Despite the fact that the Deutschtum of Manchester and Lawrence survived World war I relatively intact, and despite the upsurge of activity in the inter-war years, Germanness was actually being eroded. In fact, the history of the 
German-Americans of Manchester and Lawrence is of their attempts to establish, maintain, and preserve Deutschtum in the face of Americanization. Their dedication in preserving their small islands of Deutschtum for so long surrounded by so many non-Germans will be detailed. In the end, however, their islands were washed over by tile waves of Americanization.

Americanization may depend upon the nature of the emigration itself. Oscar Handlin's classic description was of the individual "uprooted" from a familiar society and transported to an unfamiliar one. From the very moment this individual decided to leave, the process of Americanization started, and it was an individual experience. 16 A contrary view is that the immigrants were "transplanted," and that they came either as a group or to join relatives already in America. The result is that they transplanted relationships, culture, and attitudes from the old country. Transplanted groups would tend to retain the old and resist the new for a longer time. 17 As this study will show, the ability of the immigrants in Manchester and Lawrence to retain their Germanness is, in part, explained by the fact that they were from the same area in Germany and that many joined relatives already living in the cities.

For immigrant groups the ethnic fortress against Americanization had several defenses. The primary defense was language. The national church and worship in the native language held the second line of defense. ${ }^{18}$ In some cities 
and in rural areas denominational schools were established to maintain national language and religion. 19 The ethnic clubs, which fostered group identity and sought to preserve language, formed the third line of defense. The native language press which identified issues particular to the group and attempted to preserve language also held the third line. 20 The Germans of Manchester and Lawrence like GermanAmericans elsewhere used these same defenses, their churches, clubs, and newspaper, to defend Deutschtum. Shortly after settling in Manchester and Lawrence, the German immigrants established their churches. Significantly, the German Presbyterian denomination in both cities had the largest membership, the most influential members, and the most involvement in German activities. Uncharacteristically, the Lutheran denomination was smaller and less influential. German Catholics also formed parishes for worship in German, and inter-Catholic fights over ethnic parishes did not exist since the local hierarchy encouraged the parishes. 21 All denominations had clubs and youth groups which attempted to foster their religion in the German language. As will be shown, the German Presbyterian churches were not insular and took the lead in assisting the local German schools and joining in other German activities. Paradoxically, their members, operators of small businesses and involved in politics, seemed the most likely to be Americanized. The German churches and clubs, the German schools, and

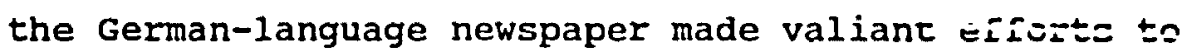


preserve the the language. John Hawgood concludes that the Germans "used their language as a weapon to ward off Americanization, and used every social milieu to preserve the German language even among their children and grandchildren."22 According to another scholar, two facts worked for and against the maintenace of languge in the two cities. The small size of the German communities may have given it some advantages in maintaining the language. 23 However, the urban setting and the much larger non-German community made its decline inevitable. 24 Despite Hawgood's conclusion, the Germans in Manchester and Lawrence recognized very early the primacy of English in employment and commerce. 25 The necessities of working and conducting commerce in overwhelmingly non-German cities meant that knowledge of English was required. Nevertheless, the GermanAmerican leaders of Manchester and Lawrence also attempted to insure that their children and grandchildren would learn German. The children attended public schools and few attended the extra German classes, further eroding the German language.

Like Germans elsewhere in America, those in Manchester and Lawrence founded the multitude of clubs, a practice for which Germans were famous. For the local Germans, these clubs provided entertainment and group identity, and they helped to maintain the language. They continued to function during world war I, through the inter-war years and even after World War II. Their longevity may be attributed to joiners or professional Germans whose livelihood depended 
upon them. The clubs preserved a Germany that existed only in the minds of the first-generation, and a Germany the second-generation did not know. The club world was neither truly German nor truly American. 26 That the clubs represented an ever smaller number of German-Americans is true. However, they did not necessarily follow the Hansen pattern of change over three generations. 27 First-generation German Americans, some of whom arrived in Manchester and Lawrence at young ages between 1880 and 1900, retained leadership roles in the clubs until the 1920 s and 1930s. A number of second-generation club leaders, either through family ties or devotion to the clubs, kept them alive long after one would have suspected that they would have ended. Recent scholarship on ethnicity and Americanization deals with class and mobility issues. The ethnic neighborhood is seen as a working class enclave. The attributes of ethnicity are viewed as working class. Upward mobility is not only a movement from the working class to the middle class but from an immigrant to an American. The neighborhood and mobility investigations of stephan Thernstrom for Newburyport and Boston, Theodore Hershberg for Philadelphia, and oliver zunz for Detroit are among such studies. 28 Herbert Gans suggests that the residents of the "urban village" of Boston exhibited working class characteristics as much as ethnic ones. 29 The chicago studies of Hartmut keil also concentrate on the dual working class and ethnicity aspects of neighborhood life. zunz is 
now willing to consider that much of this analysis placed too much emphasis on the working class and the upper class. 30 Not only is the working class emphasis contrary to the idea of the entrepreneurial, professional German whose livelihood depended upon the continuation of Deutschtum, 31 it is not completely accurate for Manchester and Lawrence. In both cities the majority of Germans were small businessmen, skilled tradesmen, or skilled workers or supervisors in the textile mills. There were working class Germans, to be sure, but the leaders and supporters of Deutschtum were the skilled workers and lower middle class.

The Germans of Manchester and Lawrence, like the Germans and other immigrant groups in other cities, tended to Iive in the same neighborhood. Located there were the German stores, churches, and club houses. In Manchester it was on the "West side," and in Lawrence it was an area north and east of the common, sometimes called "Dutch Gap." (See maps in Appendix.) Although identified as German they were not exclusively so. A German could have as a neighbor an Irishman or a French-Canadian. There was a remarkable stability in these areas up until World War II. Many persons owned small houses, operated small businesses, and remained there. A few, who became more affluent, moved to Methuen or Andover outside Lawrence or to Bedford outside Manchester. There was not the concentric out-migration suggested by Robert Park and Ernest Burgess or Sam Bass Warner for other cities. 32 The movement of Germans out of their enclaves in 
America's largest cities over time greatly reduced their German culture and Iife. ${ }^{33}$ In Manchester and Lawrence the out-migration was most noticeable after World War II. Widened horizons created by military service and the G.I. Bill coupled with the stagnant economies in both cities induced this generation to seek opportunities elsewhere. Although some moved to the surrounding towns, 34 the perception is that many more left the area entirely. This out-movement doomed Deutschtum, even if the end came slowly. World War II assured the end of Deutschtum in Manchester and Lawrence. The German-language newspaper ended publication during its sixtieth year in 1942. The German churches dropped the designation "German" or changed their names entirely. The survival of those clubs which continued into the 1970s depended upon a small number of second- and third-generation members who remained active. No one who remained active considered themselves to be anything but an American.

In fact for years the German-Americans of Manchester and Lawrence considered themselves to be Americans. Through the process of living in America they assumed what Philip Gleason calls the American identity. He further concludes that ethnic identity is easier to develop because of parentage and association, whereas the American identity is more inclusive and general because it expressed the ideals of Americanism. 35 Living in America ultimately resulted in a transformation. Individuals worked and opened businesses where they had 
contact with non-Germans; and they had to learn English to communicate. They became citizens and voted. Parents and siblings were buried here. Children were born and married, sometimes to a non-German. While becoming American they still identified with their German heritage, with each generation more removed from its language and culture.

As early as 1782, Crevecouer assigned to the American a separate identity, a mixture of "English, Scotch, Irish, French, Dutch, Germans and Swedes."36 Early in the twentieth century the idea of the "melting pot," in which all immigrants were transfused to Americans became popular. 37 It remains the popular notion of Americanization. Shortly after the melting pot idea was proclaimed, the idea of cultural pluralism was proposed. The idea here was that even with Americanizers such as the English language, groups maintained their ethnicity. 38 Earlier ideas around assimilation had centered around the "Anglo-conformity" of the immigrant group. 39 Milton Gordon, in his study of assimilation concludes that ethnicity has survived. 40 Individuals adapted to the majority or were acculturated, but they were not assimilated or integrated. There is a paradox. In the case of Manchester and Lawrence many Germans were very proud of their German culture and customs, which they kept vibrant for four decades into the twentieth century. Yet, during that time they considered themselves to be Americans. Finally, their German centers and celebrations of German culture 
ended, and they were more American than German. Perhaps, Mencken was right after all, they were devoured by the melting pot.

The German enclaves, with all their vibrancy, are now gone. In Lawrence a different ethnic enclave has now replaced it. $\mathbf{4 1}$ As will be shown the disappearance of the German enclaves in Manchester and Lawrence happened later than in most other American cities. There are several reasons for this, which will be considered in detail. German immigrants did not arrive in significant numbers until after 1870. They found no existing German enclaves and built one as they saw fit. The first generation led the clubs well into the twentieth century, providing continuity. Since many of the immigrants came from the same region in Germany they had a common identity. Their community was well served by its newspaper, the Anzeiger und Post, for sixty years. The small size of the German communities and their willingness to cooperate assisted them in maintaining their cohesiveness. The story, strengths, character, and contributions of these small German-American communities is important for what it tells us about German-Americans. Their story is being lost and has not been recounted before. 


\section{INTRODUCTION}

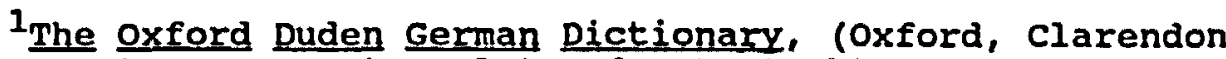
Press, 1990), p. 200, translates das Deutschtum as "Germanness or of German nationality, and the Germans (pl)." Langenscheidt's Concise German Dictionary, (London, Holder \& Stoughton, 1967), p. 146, translates it as "German character, Germanity or the Germans (pi)." Many scholars writing about German immigrants often apply it to all things associated with the German-American community, such as language, newspapers, national churches, foods, wine and beer, and culture especially, theater, music, literature, and so forth. In this study it will be broadly applied to mean the "Germanness" of Manchester and Lawrence.

${ }^{2}$ Several aspects of German emigration must be considered. Until 1871, a number of principalities and kingdoms existed rather than a German nation (or Germany). Prior to 1871, however, a cultural, ethnic, and linguistic concept of "Germany" did exist. Immigrants, speaking German, arrived in the United States from Germany, Alsace, Austria, Luxembourg, Switzerland, Russia, Bohemia, and Poland. At certain times, in the imnigration statistics Austria and Poland were included with Germany. Up until 1871, many emigrants thought of themselves as Bavarians, Rhinelanders, Saxons, Prussians, and Hessians more so than they thought of themselves as Germans. In this study, uniess otherwise identified, Germans will mean from the Germany of 1871, which includes Silesia; but Alsatians will be identified as such.

${ }^{3}$ Klaus J. Bade, "German Emigration to the United states and Continential Immigration to Germany in the Late Nineteenth Century and Early Twentieth Centuries," Central European History, 13 (December, 1980): 348-377. Hans Fenske, "International Migration: Germany in the Eighteenth Century," Central European History, 13 (December, 1980): 332-347. Wolfgang K\&llman and Peter Marschalck, "German Emigration to the Unites states," in Perspectives in American History: Dislocation and Emigratin, the Social Background of American Emigration. VII (1973), 499-534. Peter Marachalk, Deutsche überseeweanderung im 19 Jarhundert: Ein Beitrag sur sociologischer Theorie der Bevolkerung, (stuttgart, Ernest Klett Verlag), 1973. Walter D. Kamphoefner, "At the Crossroads of Economic Development: Background Factors Affecting Emigration from Nineteenth-Century Germany, in Migrations Across Time and Nations: Population Mobility in 
Historical Contexts, eds. Ira Glazer and Luigi De Rosa, 174201, (New York: Holmes and Meier, 1986). Mack Walker, Germany and the Emigration. 1816-1885. (Cambridge, Harvard University Press, 1964).

${ }^{4}$ Information taken from the obituaries in the Anzeiger und post from 1901 through 1942, for those individuals born Germany. The majority of the immigrants came from southeastern Germany especially from Saxony, Silesia, northeastern Bavaria, Thuringia, and Asch in Bohemia. See below Chapters IV and $V$.

Most of the immigrants came between 1870 and 1900 .

5H.L. Mencken, "Die Deutschamerikaner," Neue Rundschau, $39(1928)$ : 488,494 .

${ }^{6}$ F.W. Bogen, The German in America: or Advice and Instruction for the German in the United states of America: also a Reader for Reginners in the English and German Lanquages, (Boston, B.H. Green, 1851, 2nd ed.), p. 17. (This has been reprinted with a preface by Don Heinrich Tolzman, Heritage Books, Bowie, MD, 1992). F.W. Bogan was a minister at the German Evangelical Lutheran Church in Boston, Boston Directory, 1850 and 1851.

${ }^{7}$ Nathan Glazer and Daniel Patrick Monyihan, Beyond the Melting Pot, (Cambridge, M.I.T. Press and Harvard University Press, 2nd ed, 1964), pp. 311-313.

${ }^{8}$ o'Connor, German Americans, pp. 453-464. Leonard Dinnerstein, and David Reimers, Ethnic Americans: $A$ History of Immigration and Assimilation, (New York, Harper and Row, 1975), pp. 140-41, 144-145.

${ }^{9}$ Discussions of German neighborhoods are contained in Conzen, "Immigrants, Immigration and Ethnic Identity:

Historical Issues," Journal of American History, 66 (December 1979): 603-615. Agnes Bretting, "Little Germanies in the United states, in Germans to America," in Germans to America: 300 Years of Immigration, 1683-1983, ed. Günter Moltman, 141151. (Stuttgart: Institute for Foreign Cultural Relations). James Berquist "German Communities in American Cities, Journal of American Ethnic History, 4 (Fall, 1984): 9-30.

${ }^{10}$ Discussions of the disunity of the Germans are many. See, Glazer and Moynihan, Beyond the Melting Pot, pp. 111112. Kathleen Neils Conzen, "Germans," in Harvard Encyclopedia of American Ethnic Groups, ed. Stephen Thernstrom, 405-425, (Cambridge: Harvard University Press, 1980).

${ }^{11}$ Leslie V. Tischauser, The Burden of Ethnicity: The German Question in Chicago, 1914-1941, (New York, Garland 
Publishing, 1990). Tischauser maintains that neither world War I, political questions of importance to Germans, nor German candidates could unite the German-Americans of Chicago.

12 Numerous authors state that World War I essentially destroyed German ethnicity, including: John Higham, Strangers in the Land: Patterns of American Nativism, 1860-1925, (New Brunswick, Rutgers University Press, 2nd. ed. 1988), pp. 194-233. O'Connor, German-Americans. John A. Hawgood, The Tragedy of German America. (New York, Arno Press, 1970). Clifton James Child. German-Americans in Politics, 1914-17. (New York, Arno Press, 1970). Milton M. Gordon, Assimilation in American Life: The Roll of Race, Religion and National origins, (New York, Oxford University Press, 1964), p 137. It is perhaps best summed up by Moses Rischin, ed. Immiaration and the American Tradition, (Indianaplis, BobbsMerrill Co., 1976), p. xxvi, who stated "World War I shattered confidence in everything German, proving nearly fatal for German cultural life."

${ }^{13}$ Two works which acknowledge the continuance of Deutschtum past World War $I$, are Tischauer, Burden of Ethnicity, and Don Heinrich Tolzmann, Cincinnati Germans After the Great War, (New York, Peter Lang, 1987) pp. 19-82, 85-131. See also Dieter Cunz, The Maryland Germans: $A$ History, (Princeton, NJ, Princeton University Press, 1948), pp. 403-417. The Yorkville section of New York City was a famous and long lasting German-American district. See Gerard H. Wilk, "Yorkville, Twenty Years After: The Brownshirts are Gone--and much else." Commentary, 17 (January, 1954): 41-48.

14 Tolzman, Cincinnati Germans, pp. 144-164. For a discussion of Chicago see, Tischauser, Burden of Ethnicity, pp. 36-63, 132-168, and Melvin G. Holli, "Teuton vs Slav: The Great War Sinks Chicago's German Kultur," Ethnicity, 8 (December, 1981): 406-451.

${ }^{15}$ In Manchester and Lawrence German-Americans were elected aldermen or city councilors and to certain elected administrative posts such as Director of Parks; and held appointed positions such as Health Inspector. They were also elected from the local districts to the state legislatures or senates.

16 Oscar Handlin, Uprooted, (Boston, Little, Brown, 1973), and Boston's Immigrants: A Study in Acculturation, (Cambridge: Harvard University Press, 1959).

17John Bodnar, The Transplantod: A History of Immigrants in Urban America, (Bloomington, Indiana University Press, 1985). Walter D. Kamphoefner, "'Entwurzelt oder Verpflanzt?' $\mathrm{Zu}$ bedeutung der Kellenwanderung für die Einwander- 
akulturation in Amerika," in Auswanderer-WanderarbeiterGastarbeiter: Bevblkerung, Arbeitsmarkt, und Wanderung in Deutschland seit der Mitte des 19 Jahrhunderts, ed. Klaus $\mathrm{J}$. Bade, 221-271, (Ostfildern: Scripta Mercatue verlag, 1984). Kamphoefner's Westfalians from Germany to Missouri, (Princeton, Princeton University Press, 1987), is a cogent discussion of the transplantation of Westfalians to two rural counties in Missouri.

${ }^{18}$ Harold Abramson, "Religion," in Harvard Encyclopedia of American Ethnic Groups, ed. Stephan Thernstrom, 899-875, (Cambridge, Harvard University Press, 1980). La Vern Rippley, German Americans, (Boston, Twayne Publshing, 1976).

19Harold Abramson, "Religion," 869-875, Will Herberg, Catholic-Protestant-Jew, (New York, Doubleday, 1955), pp. 2238. H. Richard Niebuhr, The Social Sources of

Denominationalism, (Cleveland and New York: Meridan Books, 1962), pp. 211-213. John E. Hofman, "Mother Tongue Retentativeness in Ethnic Parishes," Nathan Glazer "The Process and Problems of Language-Maintenance: An Intergative Review," 358-368, "German Language Maintenance Efforts," 206252, and Harve-B Lemaire, "Franco-American Efforts on Behalf of the French Language in New England," 252-279, all in Lanquage Loyalities in the United States: Maintenance and Prepetuation of Non-English Mother Tonques by American Ethnic and Religious Groups, ed Joshua A. Fishman, (The Hague: Mouton and Company, 1966).

${ }^{20}$ Carl wittke, The German Lanquage Press in America, (Lexington, University of Kentucky Press, 1957).

${ }^{21}$ For a discussion of the German catholic parishes in Manchester and Lawrence see below, Chapter V. The ethnic and linguistic disputes described by colman J. Barry, The Catholic Church and German Americans, (Milwaukee, The Bruce publishing Company, 1953), are not evident in Manchester ard Lawrence.

${ }^{22}$ John Hawgood, The Tragedy of German-America. (New York, Arno Press, 1970), p. 39.

${ }^{23}$ Kloss, "German Language Maintenance," 211.

${ }^{24}$ Kloss, "German Language Maintenance, 206-252. Hoffman, "Mother Tongue in Parishes," 135. Lemaire, "Franco-American Efforts," 274 .

25 Anzeiger und Post "Lernt English," November 2, 1907. Bogen, The German in America, had concluded that "we are not real Americans because we [are] ignorant of the language," p. 17. 
${ }^{26}$ Gerard H. Wilk, "Yorkville," 41-48. James M. Berquist, "German-America in the 1890's: Illusions and Realities," in Germans in America: Aspects of GermanAmerican Relations in the Nineteenth Century. ed. E. Allen McCormick, 1-14, (New York, Columbia University Press, 1983).

27Marcus Lee Hansen, "The Third Generation in America," Commentary, 14 (November, 1952), 492-500. Hansen asserts that the second generation wants to forget the foreign

experience and that the third generation wants to relearn it. Milton M. Gordon, Assimilation in American Life: The Roll of Race, Religion and National origins, (New York, oxford University Press, 1964), p. 245. Vladimir C. Nahirny and Joshua A. Fishman, "American Immigrant Groups: Ethnic Identification and the Problem of Generations," The Sological Review, (New Series), 13 (November, 1965): 311-326.

${ }^{28}$ oliver zunz The Changing Face of Inequality: Urbanization, Industrial Development, and Immigrants in Detroit, 1880-1920, (Chicago, University of Chicago press, 1982). Theodore Hershberg, ed., et al. Philadelohia: Work, Space, and Group Experience in the Nineteenth Century. (New York: Oxford University Press, 1981). Stephan Thernstrom, The other Bostonians: Poverty and Progress in the American Metropolis, 1880-1970. (Cambridge, Harvard University Press, 1978) and poverty and progress: Social Mobility in a Nineteenth Century City, (Cambridge: Harvard University Press, 1964).

${ }^{29}$ Herbert J. Gans, The Urban Villagers: Group and class in the life of Italian-Americans, (New York, The Free Press, 1982)

${ }^{30}$ oliver Zunz, "American History and the Changing Meaning of Assimilation," Journal of American Ethnic History, 4 (Spring, 1985): 64, 66. Zunz concludes that social historians were "in a hurry to enshrine workers and to condemn robber barons as villans."

${ }^{31}$ James M. Berquist, "German-America in the 1890's: Illusions and Realities," in Germans in America: Aspects of German-American Relations in the Nineteenth Century. ed. E. Allen McCormick, (New York, Columbia University Press,) 1-14.

${ }^{32}$ Robert E. Parik, Ernest $w$. Burgess, and Robert D. Mckenzie, The City, (Chicago, The University of Chicago Press), 1925. Sam Bass Warner, Jr. Streetcar Suburbs: The process of Growth in Boston, (1870-1900), (Cambridge, Harvard University, Press, 1978). 
${ }^{33}$ Audry L. Olsen, St. Louis Germans, 1850-1920: The Nature of an Immigrant Community and its Relation to the Assimilation process, (New York, Arno Press, 1980), pp. 233255. Andrew $P$. Yox, "The Decline of the German-American Community in Buffalo, New York, 1855-1925. PhD Diss, University of Chicago, 1985, p. 319. Stanley Nadel, Little Germany: Ethnicity, Religion, and Class in New York. 184580, (Urbana, University of Illinois Press, 1990) pp. 160-162. Wilk, "Yorkville," 41-48.

${ }^{34}$ Kenneth T. Jackson, crabgrass Frontier: The Suburbanization of the United States, (New York, Oxford University Press, 1985).

${ }^{35}$ Philip Gleason, "American Identity and Americanization," in Dimensions of Ethnicity, ed. Stephan Thernstrom, (Cambridge, Harvard University Press, 1982), 137.

${ }^{36}$ Hector st. John Crevecour, "Letters from an American Farmer," in Immigration and the American Tradition, (Indanapolis, Bobbs-Merrill Co., 1976), p. 23.

37 Milton M. Gordon, Assimilation in Ameican Life, The Roll of Race, Religion and National origins, (New York, Oxford University Press) 1964, pp. 115-131. The melting pot was widely accepted in the early twentienth century because it fit the mood and hope that the newer immigrants could be absorbed by America. The term popularized by Israel Zwangwill's play, The Melting Pot, first performed in 1908. see also, Gleason, "American Identity," 80-83.

${ }^{38}$ Milton M. Gordon, "Assimilation in America: Theory and Reality" Daedalus, 90 (1961): 274-279, and Milton $M$. Gordon, Assimilation in Ameican Life. pp. 132-159. Cultural Pluralism was first put forward in 1915 by Horace Kallen. See also, Gleason "American Identity," 96-109.

${ }^{39}$ Gordon, Assimilation in Ameican Life. pp. 84-114.

40 Ibid., pp. 233-265. Gleason, American Identity," concludes that an American nationality does exist, 140 .

${ }^{41}$ The population of Lawrence is now heavily Hispanic, and it is identified as a Hispanic city. On the other hand, no single ethnic group currently predominates in Manchester.

Glazer and Moyinhan in Beyond the Melting Pot: The Negroes, Puerto Ricans, Jews, Italians, and Irish of New York city, concluded that the melting pot did not work when applied to the ethnic groups listed in the subtitle (p. xcvii). However, they found that the Germans had completely disappeared ( $p .311$ ). This seems contradictory. In the case of the Germans, perhaps they did not look at Yorkville or 
sections of Brooklyn. For the Irish the issue was probably one of political control rather than pure ethnicity. In the case of the Puerto Ricans, Italians, and Jews perhaps they did not consider how additional time and an additional generation born in America would increase assimilation.

The length of time in the country, the number of generations, and the effects of public schooling and television is perhaps evident through a recent observation in Lawrence. That city is now so so Hispanic that signs in public places and buildings are in both English and Spanish. While waiting to enter the Lawrence city Library, the author noticed a group of Hispanic high school students also waiting to enter. They were all female and probably in about the ninth or tenth grade. They were talking among themselves in English. They can probably also speak Spanish or are familiar with it. That they spoke English among themselves, would probably indicate the same dissipation of ethnicity and language as experienced by the Germans in Lawrence years earlier. 


\section{CHAPTER I}

\section{PATTERNS OF GERMAN SETTLEMENT IN THE UNITED STATES \\ AND}

GERMANS IN NEW ENGLAND

Since the arrival in 1683 of thirteen Mennonite families in Philadelphia, over seven million Germans immigrated to the United States. 1 of this number only a small proportion settled in New England, and most came at the end of German mass migration to the United States. In order to understand more fully the distinctive features of the German-American communities of northern New England, the patterns of German settlement within the United states and New England must be discussed. A summary of the causes of emigration, the German regional origins of the emigrants, the time frame of migration and the settlements in the United States will provide a framework for comparisons to the German communities in Manchester and Lawrence.

During the late seventeenth and early eighteenth centuries, the smaller states of southwestern Germany which became the battlegrounds of the religious and dynastic wars of the period contributed the most to the emigration. The Rhine River was the avenue of escape from the Palatinate, Württemberg, and Baden, and neighboring Switzerland. The area had hardly recovered from the Thirty years war (1618-48) 
when the French invaded in 1680 and again in 1688-89. Nineteen years later (1707) the War of Spanish Succession further reduced arable land and displaced many people. Additionally, the peace settlement of the Thirty Years War dictated the status of Lutheranism, Catholicism and the Reformed Church, but left a number of smaller sects, such as Pietists, Mennonites, and Schwenkfelders open to persecution. Consequently they were willing to emigrate to British North America. 2

William Penn visited Germany and actively recruited the Mennonites, who first settled in Pennsylvania in 1683. As a result of the relative religious tolerance in Pennsylvania, increasing numbers of Germans settled there founding the enclave, known appropriately, as Germantown. ${ }^{3}$ Here the settlers became prosperous by spinning flax and established the first center of German culture in America. This attracted other migrants, but even those who did not stay found Germantown a convenient starting point for migration west and south. ${ }^{4}$ Throughout the eighteenth century Germans continued to migrate to the New World, most still settling in Pennsylvania. One historian suggests that between 1749 and 1754 more than 30,000 Germans settled in Pennsylvania. ${ }^{5}$ By the time of the First Census of the United States in 1790 , Pennsylvania's population of 434,000 contained over 160,000 Germans, and in Lancaster County Germans made up seventy percent of the population. 6

In Colonial times, the leaders of Pennsylvania became 
concerned about this concentration of seemingly unassimilable Germans. Even Benjamin Franklin worried not only about their numerical strength but also their penchant for retaining the German language and customs. One of his early gifts to his home city of Boston was a scheme to divert German settlers there, relieving the pressure on Philadelphia. 7

For German immigrants, Philadelphia remained the main port of entry and Pennsylvania the preferred destination, but they also settled in other colonies. In 1708, Palatinate refugees from the War of Spanish Succession were living in England supported by the crown and other persons. To end this expense, the government sent them to the the Hudson River Valley to establish a buffer against the Indians and to help produce stores for the English Navy. Palatines and Swiss Germans also settled in the Carolinas, where the most notable settlement was New Bern. During the eighteenth century Germans had moved into Maryland and virginia, especially the Shenandoah valley. ${ }^{8}$ At the end of the Colonial period most German settlers were concentrated in the Middle Atlantic States. After the American Revolution Germans from Virginia settled areas of Kentucky and Tennessee. Others pushed out from Fort Pitt using the ohio River to settle the territory of ohio, especially around Cincinnati and along the Miami valley. 9

In the early nineteenth century, German immigration shifted to the ports of Baltimore and New orleans as a result of the tobacco and cotton trades. Ships sailing westward to 
obtain cargoes of tobacco or cotton filled empty spaces with people. 10 Thus, immigrants became human ballast. From Baltimore, immigrants moved out into Pennsylvania, Ohio, Virginia, or Tennessee. From New orleans, they moved up the Mississippi River, settling in the St. Louis area. Once New York became a main port of entry, immigrants used the Hudson River and the Erie Canal, and later the parallel railroad routes, to move inland to Buffalo and across the Great Lakes to settle the upper midwest, especially in wisconsin.11 BY 1900 the "German Belt" (Deutscher Gürtel) stretched from New York City through New Jersey and Pennsylvania, Ohio, Indiana, Illinois, Missouri, Kansas, Nebraska, Minnesota, and wisconsin, to the Dakotas.

Although many Germans settled on the rich farm lands of the middle west many more settled in the cities. Around 1900, the number of German immigrants and their children was so large in certain cities that they became identified as "German." In Milwaukee Germans were fifty-two percent of the total population. Cincinnati's Germans were forty-two percent of that city's population. In st. Louis the German inhabitants made up thirty-five percent of the population. In other cities Germans made up a sizable percentage of the population. These included: Buffalo (thirty-two percent), Chicago (twenty-five percent), Allegheny (twenty-nine percent), New York (twenty-two percent), Pittsburgh (twenty percent), Baltimore (eighteen percent), and Philadelphia (fifteen percent). 12 In each of these cities the Germans 
founded churches and clubs, organized social, musical, and cultural events, and engaged in varying degrees in the political life of the cities.

It was during the nineteenth century that the majority of Germans entered the United states. 13 Emigration initially increased immediately following the Napoleonic Wars. Conditions on land and seas during the wars sharply reduced the migration of people. However, after the wars the reopening of routes of migration coupled with bad weather, poor harvests, and a conservative crackdown resulted in an increase in emigration. As in the past, the emigrants came from the Rhineland and southwestern Germany and followed the Rhine to ports in the Netherlands. According to historian Mack Walker, in 1816 officials in Baden had issued emigration passes for 18,000 persons, or two percent of the population of the Duchy. 14 In addition to the small farmers who left, there were a number of liberal exiles including Karl Follen, Franz Lieber, and Karl Beck, who settled in Boston. There was considerable misery associated with this emigration "fever." Word soon filtered back regarding the terrible conditions of emigrants stranded in the Netherlands, shipwrecks, and the need for many of the emigrants to assume contracts of indentured servitude to obtain passage. 15 such factors dampened emigration until the 1830s.16

Walker has noted, "1830 and 1831 in Germany were years of cholera, popular uprisings, and rumors of revolution and war."17 Increased population, an inability of the 
agricultural and production resources to keep up with it, high taxes and inexpensive land in America were motives for emigration. At this time the nascent industries in Germany began to replace the handicraft system with semi-skilled industrial labor, especially in textiles. During this time, there was also migration within Germany with movement from farms to cities, and from province to province. The Kingdom of saxony, due to its relatively advanced industries, gained a number of internal migrants. Many others felt that they had no future in Germany and decided to emigrate. In Walker's estimation the emigrants of this period were probably better educated and more prosperous than at any other time. He classified them as "decidedly" of the lower middle class; small farmers, who cultivated their own land; independent village shopkeepers and artisans; and very few from large towns and big cities. 18 Between 1830 and 1839 over 124,000 Germans emigrated to the United States with over 20,000 arriving in each of the years 1836,1837 , and 1839. A number of of liberals, the so-called Dreissiger, emigrated after the revolutions of 1830. Among the more famous were Gustav Korner, J. Bernhard Stallo, Dr. Konstantin Herring, and Friedrich Münch. 19

The failed German Revolution of 1848 stimulated the emigration of the "Forty-Eighters" who were distinguished in the United States by the leadership of Carl Schurz, Karl Heinzen, and Friedrich Hecker. 20 The famous Forty-Eighters 
were but a small portion of the German emigration between 1848 and 1855 , since over 840,000 emigrated in that period including 215,000 in 1855 . The potato rot which produced the famine in Ireland and the diaspora of the Irish to America also affected Germany, where in 1846 much of the potato crop was ruined. Furthermore, a poor rye crop worsened the situation.21 Additionally, this was a time of industrial depression and unemployment, and those emigrating had less money than their predecessors. Between 1848 and 1851 conditions improved somewhat and emigration declined to pre 1846 ievels. Harvests worsened again between 1850 and 1853 and emigration increased. The situation was not only bad in the farm regions but in the urban centers as well. Theodore Hammerow explains that the depression "had a catastrophic effect on urban living conditions," and "twenty-five percent of the population of cologne was dependent on public assistance."22 According to walker, the more than a half a million Germans who emigrated between 1852 and 1854 represented one and one-half percent of the population of Germany. 23 summarizing this movement Hammerow notes, "the Eigure of the liberal ancestor fleeing tyranny and injustice in Germany to breathe the free air of the United states has become enshrined in millions of hearts in the American Midwest, but the truth is that for every Carl schurz among the immigrants there were hundreds who wanted nothing more than a secure livelihood." 24 Residents of the cities and agricultural regions along the Rhine and the lands of 
southwestern Germany left their homes to seek opportunities in America. 25

Between 1846 and 1860 over one million Germans settled in the United states. The preissigers sometimes called them "greens" meaning newcomers. Among the "greens" the brash liberal revolutionaries conflicted with the more settled and now conservative Dreissigers, derisively called the "grays" by the newcomers. Such conflicts were but another example of disunity among German emigrants. The Forty-Eighters added to the decided German flavor of many of the cities and states of the Midwest. It seemed as if every revolutionary was a newspaper editor, for the German-language press doubled in these years. The exploits of the "Forty-Eighters" in saving Missouri for the Union and fighting in the civil war are well known. 26

The attempts between 1830 and 1860 to establish "New Germanies" in America are particularly interesting. One such attempt was made in the early 1830 s by the Giessener Gesellshaft in 1834 in Missouri. Led by Paul Follen and Friedrich Münch the group could be best described as "Latin Farmers." The members soon gave up the ideas of a communal society for more individual ownership of land. However, the town of Hermann remained a German enclave well into the twentieth century. A more ambitious and slightly more successful project was the settlement of Neu Braunfels in Texas by the Adelsverein in 1845. In addition to the harsh conditions on the frontier, and the change in the status of 
Texas (annexation by the United States), the idea of feudalizing Texas for the German nobility proved inappropriate. Thus, the colonizing scheme failed, but the small towns of New Braunfels and Fredericksburg remain Germanic to this day. As Wisconsin became the magnet for large numbers of Germans, thoughts turned to the idea of a "New Germany" within the state. The idea of creating a German Colony in Wisconsin seems to have been the dream of a number of idealists rather than a practical plan. 27

Between 1880 and 1889 the third and largest wave of Germans immigrated to the United states. During those nine years almost a million and a half Germans entered the United states, including over a quarter of a million in 1882 alone. 28 This largest and last significant influx of Germans differed from the previous immigrants in a number of ways.

An important change was a shift in place of origin from southern and western Germany to northern and eastern Germany. Farm laborers displaced from the large estates of the east, particularly in East Prussia, and laborers departing cities predominated during the decade of the eighties. 29 In some instances this was a two step migration; first from the farm to a German city and then to an American city. These immigrants were more likely to settle in New York or the industrial cities of the east and midwest than on farm lands. German industry, although increasing its capacity during this period, was still not able to provide sufficient jobs for all the available workers. Furthermore, the center of industrial 
production was shifting from saxony and silesia to the Ruhr area, displacing workers. Once on the move, they may have decided to move to America rather than to the newly industrializing areas of Germany, which could draw on their own overpopulated hinterlands. At that time Germany experienced high unemployment (15.5\% from 1880-1884 and $11.5 \%$ 1885-1889) 30 which no doubt encouraged workers to seek jobs in America.

once again, the new German immigrants changed the character of the German-American Community. From this group came the labor radicals, so notorious in the labor disputes of the late 1880s and the 1890s. And once again, between 1872 and 1892 the German-language press doubled in order to serve the new German readers. 31 Also, these German immigrants having lived through the triumph of Germany in Europe and the realization of the goal of a unified Germany, tended to view the Imperial Government in a more favorable light than their revolutionary predecessors had viewed the governments of the various kingdoms and duchies. 32 It is this group of immigrants who tried to keep German language and culture alive--to preserve Deutschtum--into the twentieth century.

The turn of the twentieth century marks the high point of German population in the United States. According to John Hawgood over eighty percent of Germany's total emigration to the United States occurred between 1840 and 1900.33 In 1900 German-Americans represented thirty one percent of the total 
population of the United states, which was the highest it would ever reach. Hawgood concludes that 1900 represented the Germans "at their relative numerical zenith, as well, probably, at the zenith of their prestige as an 'element' in the population and life of the United States." 34

\section{German settlement Patterns in New England}

As explained, most of the German immigrants settled in the so called "German Belt" in the Middle Atlantic and Midwestern States. Only about twelve percent of GermanAmericans lived outside this belt, and probably only about one percent in New England. 35 However, this is not to say that Germans were totally absent from New England, since there were German settlers from the eighteenth into the twentieth centuries. Additionally, nineteenth century German intellectual emigrés greatly influenced the intellectual and educational leaders of New England. Before discussing the emigrés, the earlier German settlements will be described.

Vast unsettled spaces, foreign enemies, land speculation, and protestant sympathies resulted in attempts to settle German Protestants on the frontier of New England. Probably, the most ill-fated of these attempts were those made by Samuel waldo. The son of a merchant representing a Hamburg trading house in Boston, Waldo was educated at Harvard and in Germany. While there he entered the Hanoverian military and eventually served in the bodyguard of the Elector, who became George I of England. It can be 
surmised that this connection may have been of assistance to him later in life. In 1724, Samuel returned to Boston to take over his father's business and became involved in land speculation in Maine, then part of Massachusetts. In 1740 , Waldo convinced a number of German families from Brunswick and saxony to found the town of Waldoboro, at the mouth of the Medomak River (about 60 miles north of Portland). 36 Their life on Waldo's land in this remote wilderness was apparently anything but pleasant.

Waldo hired an agent to work in Germany to induce further settlement, and in 1742 approximately 150 more Germans were convinced to settle in Waldoboro. An October arrival in Maine, just before the start of a New England winter, was hardly an auspicious beginning for this second group. By the spring of 1743 the survivors were too poor and weak to improve their conditions or to leave the settlement. They addressed their grievances to the General court of Massachusetts, which assigned blame to all parties, but offered no relief for their miserable condition. 37

Dynastic wars in Europe, begun in 1744, soon involved the northeastern coasts of North America. In 1745 a joint British and Colonial expedition attacked Louisburg in Nova Scotia. Samuel Waldo served as a brigadier-general for the Colonists, and a number of Germans from Waldoboro joined the expedition. However, in 1746, while they were gone, Indians attacked and destroyed the settlement, leaving rew survivors. After the war, Waldo attempted to resettle the town and 
induced some Philadelphia Germans to move to Waldoboro. 38 However, the settlement attracted only a few additional German settlers. It remained merely an outpost with traces of German culture lasting into the nineteenth century. The threats from the French in Nova Scotia, and the perception that Germans were settling in Nova scotia, led to other attempts to settle German Protestants in Massachusetts and Maine. In 1749 Massachusetts approved land in the western part of the state for foreign Protestants. At that time, Joseph Crellius from Philadelphia was employed by Massachusetts as an agent for attracting German settlers into the specified frontier areas. In December, 1751, he landed about twenty or thirty families along the Kennebec River, at what is now known as Dresden, Maine. In 1753 he also succeeded in settling some redemptioners in Western Massachusetts. Meanwhile, Waldo tried to induce more Germans to settle in Waldoboro, and a few more arrived in 1753.39 At best these settlements remained small outposts of minor significance.

About the same time, Benjamin Franklin planned to create a new Germantown in Braintree, outside of Boston. German merchants and trade representatives in Boston may have already formed a small enclave in Braintree. 40 Another explanation is that the German settlement resulted from a land and business speculation scheme and a plan to divert Germans from Philadelphia to Boston. In 1750 John Quincy leased land in Braintree to Benjamin Franklin's brother John 
and Peter Etter, both of Boston, and Joseph Crellius of Philadelphia. Benjamin Franklin was concerned about the large concentration of Germans near Philadelphia and their habit of maintaining the German language. They also tended to vote against his interests. Therefore, he hoped to divert Germans from Philadelphia to Boston, and onto the lots he had purchased in Braintree. Almost half of the lots were to be given free, in order to attract settlers and thereby increase the value of the others. Only German Protestants were eligible to participate in the settlement. In order to provide for an industry a glass works was built and operated by German workers. In 1751, crellius successfully settled fifty families in Boston's "Germantown."41 Apparently, the whole effort folded by the early 1760 's and few Germans remained in the area after that.

German influences on the field of education in nineteenth century Boston were more lasting. Between 1815 and 1819 the first Americans studied at the University of Gottingen. of these, George Ticknor, Edward Everett, George Bancroft, and Joseph Cogswell returned with positive ideas of German educational methods which influenced their careers. They also assisted young scholars fleeing repression in Germany, including Karl Beck, Karl Follen and Franz Lieber who, themselves, influenced education in Boston. 42

Upon their return from Germany, George Bancroft and Joseph Cogswell established the Round Hill School in 
Northampton, Massachusetts, and introduced a number of German and Swiss educational methods. Karl Beck, born in Heidelberg, arrived at the school in 1824, having been recommended to George Ticknor by Lafayette. At Round Hill, Beck taught Latin and also established an indoor gymnasium for physical education, based on the Turner methodology of Friedrich Jahn. He remained at Round Hill until 1830, when he left to run his own school in New York. However, in 1838 he returned to Massachusetts and taught Latin and Literature at Harvard until 1852.43

Karl Follen, a native of Giessen, arrived in New York in 1824 and resided in Philadelphia for almost a year although Lafayette had also recommended him to Ticknor. In 1825, Ticknor offered him a position as instructor of German language at Harvard. Finding no suitable books for instruction, Follen produced an anthology of German literature and a guide to German grammar, which continued to be used at Harvard for years after he left. If nothing else, Follen married well, taking Eliza cabot, daughter of the wealthy Boston trader samuel Cabot, as his bride. Through this family connection, he had access to many of the literary and political luminaries of Massachusetts. In 1830 he was appointed Professor of German Literature at Harvard for a period of five years, at the end of which, his anti-slavery sentiments prevented him from obtaining a reappointment. Follen was impressed by the Turner methods of gymnastics, and he introduced physical training to Harvard and established 
the Tremont Gymnasium, the first public gymnasium in the United states. His early death in a steamship accident in 1840 ended his influences on education. ${ }^{44}$

Franz Lieber, a veteran of the Napoleonic wars and a volunteer in the Greek Revolution, arrived in 1827. Even the patronage of the diplomat and historian Barthold Niebuhr could not keep him out of Prussian prisons. Fortunately, a letter from his patron secured Lieber a position as director of the Tremont Gymnasium. He founded a swimming school in Boston which merited a visit from President John Quincy Adams. Later as a professor of law at Columbia, he became an expert on jurisprudence, and during the civil war he wrote a "Code of War" for the Union Armies. At the time of his death he was serving on a commission for the adjudication of claims with Mexico. 45

The four pioneer New Englanders who attended German universities were the first of many who would influence American education in New England and the United States. Between 1820 and 1920 an estimated nine to ten thousand Americans studied at German Universities. 46 Among the other New Englanders who went to Germany were Henry Baxter Adams, Horace Mann and William Emerson. 47 The latter may have influenced his younger brother Ralph Waldo Emerson, and his Transcendential Philosophy which borrowed from German Romanticism. 48 Horace Mann, who became the first commissioner of Education in Massachusetts in 1837, attempted to introduce a number of European methods into the 
Massachusetts schools. 49

Massachusetts was also at the forefront of modern educational innovation, thanks to the work of the revolutionary "Forty-Eighter," Carl Douai. Sentenced to several prison terms in Germany because of revolutionary writings, he managed to leave in 1852, settling in Neu Braunfels, Texas. There he edited a newspaper, whose editorial content became increasingly anti-slavery. Naturally, this made him unwelcome in Texas and he left in 1856 for Boston. In Boston he founded a school and organized the first kindergarten in the United states. 50

As mentioned before, it often seemed as if almost every radical "Forty-Eighter" was a newspaper editor. One who settled in Boston was Karl Heinzen. Born near Düsseldorf, Heinzen was a life-long revolutionary and radical. In 1850 he fled Germany, settling in Louisville, where he started Der Pionier, which was uncompromisingly liberal in its opinions. Heinzen envisioned Der Pionier as a national paper with a liberal viewpoint. Financial problems caused him to move from city to city and in 1859 he finally settled in Boston. With fewer than 6,000 Germans Boston would hardly seem to be a likely place for a radical German-language newspaper, but Heinzen felt that Boston was the center of freedom. Since Der pionier was to be national, he felt no need to cultivate the small German community and its fledgling clubs in Boston, and he was apparently resented for it. Never successful financially, Heinzen moved his paper and family several 
times, until he received the patronage of a fellow-radical,

Dr. Marie E. Zakrzewska. The Heinzen family moved into Dr. zakrzewska's house in the Roxbury section of the city, a section which later became the center of Boston's small German community. Through Dr. zakrzewska, Heinzen met the radical abolitionists William Lloyd Garrison, Wendell Phillips, Julia Howe, and Lucy Stone. Another of Heinzen's friends was Louis Prang, a "Forty-Eighter," who was operating a successful lithography business in Boston. Heinzen enjoyed the company of the abolitionists of Boston and strongly supported the Union cause during the Civil War. 51

During the nineteenth century German musicians helped turn Boston into a recognized musical center. Hannover born Johann Graupner, and a performer in Haydn's Orchestra, had settled in Boston in 1797. Graupner is credited with organizing an amateur orchestra and founding, in 1815, the Handel and Haydn Society, which has lasted to the present. Carl Zerrahn first visited Boston while on tour in 1849 with the Germania orchestra. A few years later he returned to stay and was very influential in the musical affairs of Boston and eastern Massachusetts. He conducted the Handel and Haydn society from 1854-1894. Meanwhile, German or Austrian musicians conducted the Boston symphony from its founding in 1881 until 1918.52 German music and German musicians helped create a favorable impression of Germany and of German immigrants in the eyes of the citizens of Boston. It is important to note that German music, educational 
methods, and philosophy had positive influences on and were favorably received by the intelligentsia of Massachusetts. This is best described by Barbara Miller Solomon,

Ever since George Ticknor and Edward Everett had gone to study in Germany, in 1815, the country of Goethe, Herder, Schleiermacher, and Ranke had been a symbol of intellectuality and scholarship to cultured Brahmins. So Longfellow and Lowell had drunk deep of German literature, Emerson of its philosophical idealism, while Bancroft and the great train of historians thereafter paid a debt to Teutonist principles and methods of research. Louisa May Alcott's Professor Bhaer in Little Women (published in 1868) depicted the German as a warm, music-loving, intellectual, conversant in philosophical trends with the New England transcendentalist father. 53

Another example of the high regard for Germany and Germans in the late nineteenth century were the theories that ancient Germany was the source of liberty. In 1881 Herbert Baxter Adams argued that the New England town form of government was directly descended from the forests of ancient Germany. He declared in the "Teutoburger Wald and other forests liberty was nurtured."54 Even if wrong, and discredited by other scholarship, the view was widely held for a number of years.

Such views, held by the intellectual leaders of Massachusetts, at least through the nineteenth century led to a relative tolerance of the German immigrant. The German came to be viewed as industrious, intelligent, neat, thrifty, and law abiding. They were perceived relatively positively. In the middle part of the century they were viewed much more favorably than the Irish, then streaming into Boston. At the 
end of the century and into the early twentieth century they were viewed more positively than the Italians, Polish, and other southern and eastern European immigrants.

Eventually there were other German immigrants to New England beside the very well educated revolutionaries and the poor unfortunate souls led to Waldoboro. As a matter of fact, up until the last quarter of the nineteenth century, New England had received relatively few of the average German immigrants. However, during the last thirty years of the nineteenth century, German immigrants settled into the industrial and commercial cities of New England. A majority of these immigrants came from the industrial lands of saxony and Silesia more than from southwestern or northeastern Germany. 55 once settled these immigrants were workers, craftspersons, and tradespersons and small entrepreneurs. Apparently they were neither as poor as the Irish who arrived during potato famine nor as the Italians who would start arriving in the 1890 s. 56

It is the immigrants from the industrial lands of Germany who arrived between 1870 and 1900 who settled in Lawrence, Manchester, and the other mill towns of New England. So many settled in Lawrence that its German population was exceeded only by Boston. Taken together the Germans of Lawrence and Manchester were a significant community. In addition to Lawrence and Manchester, Germans settled in Boston, Holyoke, Clinton, Fitchburg, Adams, Springfield, and Cambridge in Massachusetts and Providence 
and Pawtucket in Rhode Island. 57 In each city they tended to live in neighborhoods with German businesses, churches, and club houses. In each city they established stores and small service businesses, sometimes they founded factories or breweries, and they were prominent in certain professions such as doctors, musicians, and music teachers. They also found jobs in the predominant industries of the cities, such as textiles in Manchester and Lawrence, or in manufacturing companies founded by Germans, such as the Germania Woolen Mills founded in Holyoke by German natives. 58 In Rhode Island they were involved in the jewelry and textile industries. 59 Boston, which was less of a manufacturing and more of a commercial center, the Germans found employment in a number of small manufacturing businesses and in the service trades. 60

Whether in cities of New England or the cities of the Midwest, German-Americans founded distinctive German districts. Within these districts German language and culture were practiced. Despite the German districts, the German-Americans struggled to maintain Deutschtum against the forces of Americanization. This struggle between ethnic preservation and assimilation in several cities, especially in the Midwest, will be detailed in the next chapter in order to better understand the German-Americans in Manchester and Lawrence. 
${ }^{1}$ Albert Bernhardt Faust, The German Element in the United States, (New York: The Arno Press, 1969), Vol I, p. 34. Bernard Bailyn, Voyages to the West, (New York, Knopf, 1987), p. 25, accepts Faust's figures. Stephen Thernstrom, ed. Harvard Encyclopedia of American Ethnic Groups, (Cambridge, Harvard University Press, 1980), Table 3, pp. 1047-1049, which is based on the 1975 Annual Report:

Immigration and Naturalization Service, (Washington, 1976, Table 13, pp. 62-64, totals immigrants from Germany between $1820-1975$ as $6,954,160$. Kathleen Niels Conzen, "Germans" in Encyclopedia of Ethnic Groups, 407, 409, estimates German arrivals during the Colonial Period between 65,000 to 100,000 , and another 20,000 between 1816-1817. This totals over seven million to 1975. Also, between 1820 and 1975 an estimated 348,468 immigrants arrived from Switzerland, many of whom spoke German.

Although there were Germans in America prior to 1683, the arrival of the Mennonites on the Concord is celebrated as the start of mass German immigration.

2 Faust, German Element, Vol I, pp. 30, 53-60, 72-3.

${ }^{3}$ The religious freedom of Pennsylvania attracted a number of religious sects including the Moravians and the Amish. The latter settled heavily in eastern Pennsylvania, have retained many customs of the seventeenth century, and are now commonly known as the "Pennsylvania Dutch." Since they are separated from the mainstream of German-Americans they will not be considered further.

${ }^{4}$ Faust, German Element, Vol I, pp. 31, 37, 47112.

${ }^{5}$ Alfred A. Curran German Immigration to Pennsylvania, 1683-1933. (Columbus, GA., Brentwood University Press, 1986), p. 23. Bailyn, Voyages, pp. 25-27.

6 Faust, German Element, Vol II, p. 14 .

${ }^{7}$ Curran, Pennsylvania Germans, pp. 38-9. Madlyn Allen Jones, American Immigration, (Chicago: University of Chicago, 1960), pp. 48, 107, 110, 133. Karl Arndt, "Franklin's Lost Map of Germantown, Massachusetts," Pennsylvania Folklife, 31 (1981-82), 87-89. Roger Daniels, Comming to America: A History of Immigration and Ethnicity 
in American Life, (New York: Harper Colliers, 1990), pp. 109-110. Daniels sugests that Franklin's ire was generated as much by politics--the Germans tended to vote against his interests-as by ethnic dislike.

${ }^{8}$ Faust, German Element, Vol I, pp. 73-76 163-4, 173, $177 f f$; Curran, Pennsylvania Germans, pp. 57-58. Daniels, Coming to America, pp. 149-150. Conzen, "Germans" in Encyclopedia of Ethnic Groups, 411-413.

${ }^{9}$ Faust, German Element, Vol I, pp. $357 \mathrm{ff,} 391 \mathrm{ff}$.

${ }^{10}$ Philip Taylor The Distant Magnet: European Emigration to the U.S.A., (New York, Harper \& Row, 1971), p. 92 . Daniels, Coming to America, p. 149. Faust German Element, Vol I, pp. 163-4 also suggests that German settlers to Maryland in the Colonial period migrated from Pennsylvania.

11 Faust, German Element, Vol I, pp. 468-490. Daniels, Coming to America, pp. 66, 67-68. Taylor Distant Magnet, pp. 92-93, 141-144.

${ }^{12}$ Some comparative population figures for Germans in selected us cities in 1900 are:

city Total

Population

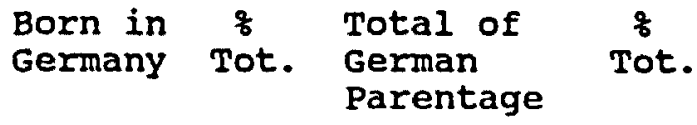

$\begin{array}{lrrrrr}\text { New York } & 3,437,202 & 322,343 & 9.3 & 761,795 & 22.1 \\ \text { Chicago } & 1,698,575 & 170,738 & 10.0 & 416,729 & 24.5 \\ \text { Philadelphia } & 1,293,697 & 71,319 & 5.5 & 190,182 & 14.7 \\ \text { Milwaukee } & 285,315 & 53,854 & 18.7 & 146,846 & 51.4 \\ \text { St Louis } & 575,238 & 58,781 & 10.2 & 199,182 & 36.6 \\ \text { Baltimore } & 598,957 & 33,208 & 5.5 & 107,506 & 17.9 \\ \text { Cincinnati } & 325,902 & 38,219 & 11.7 & 136,807 & 41.9 \\ \text { Buffalo } & 352,387 & 36,720 & 10.4 & 113,102 & 38.8 \\ \text { Pittsburgh } & 321,616 & 21,222 & 6.5 & 64,204 & 19.9 \\ \text { Allegheny } & 129,896 & 12,022 & 9.2 & 37,270 & 28.6 \\ \text { Boston } & 560,892 & 10,523 & 1.8 & 25,119 & 4.4\end{array}$

Source Faust, German Element, Vol I p. 580 from the Twelfth Census of the United States, Vol $I$, (Population) Part I, pp. 878-881, 882-885, 890-893.

By Comparison:

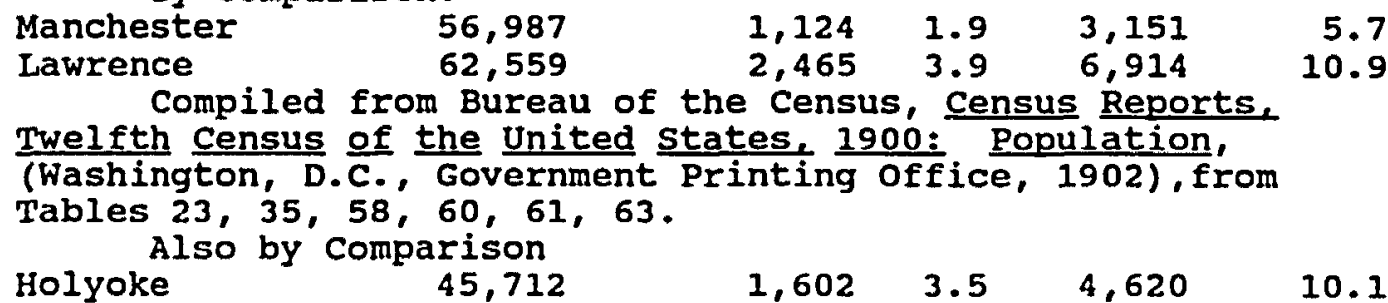
Compiled from the same source. Holyoke is the only other northern New England City whose German community has 
been investigated. Gerhard Hiesinger, "Die deutsche Einwandererkolonie von Holyoke, Massachusetts, 1865-1920," PhD Diss, Universitat München, 1990. To appear under the same title in book form in 1994, stuttgart: Franz steiner Verlag.

${ }^{13}$ Between 1820 and 1910 approximately 5,008,000 Germans immigrated into the United States. U.S. Bureau of the Census, Historical statistics of the United States: Colonial Times to 1970, (Washington, D.C., Government Printing office, 1975), Vol I, p. 120 .

${ }^{14}$ Mack Walker, Germany and the Emigration, 1816-1885, (Cambridge, Havard University Press, 1964), p. 7 .

15 Ibid. . p. 17.

16 Walker, Germany and Emigration, pp. 1-41, and Wittke, We Who Built, pp. 188-191. Theodore S Hamerow. Restoration, Revolution, Reaction: Economics and Politics in Germany, 1815-1871. (Princeton, Princeton University Press, 1967), pp. 3-37. Walter D. Kamphoefner, "At the Crossroads of Economic Development: Background Factors Affecting Emigrantion from vineteenth Century Germany," in Ira Glazer and Luigi De Rosa, eds., Migrtions Across Time and Nations: Population Mobility in Historical Contexts. (New York, Holmes and Meier, 1986) pp. 174-201. Wolfgang K8llman, and Peter Marschalck, "German Emigration to the United States," in Perspectives in American History: Dislocation and Emigration, the Social Background of American Immigration. VII, (1973), 499-534.

${ }^{17}$ Walker, Germany and Emigration, p. 65.

${ }^{18}$ Ibid., p. 51 .

${ }^{19}$ Walker, Germany and Emigration, pp. 46-65. Wittke, We Who Built, pp. $191-2$. statistics are from Historical

Statistics of the United States, p. 106. Hamerow,

Restoration, Revolution, Reaction, pp. 3-37. Kamphoefner,

"At the Crossroads," 174-201.

${ }^{20}$ Carl wittke, we who Built, pp. 193-4.

21 Ibid., p. 72 .

22 Hammerow, Restoration, Revolution, Reaction, p. 80 .

23 Walker, Germany and Emigration, p. 157.

${ }^{24}$ Hammerow, Restoration, Revolution, Reaction, p. 82 . 
25Wittke, We Who Built, pp. 193-4. Walker, Germany and Emigration, pp. $71,72,74,154,157,159-60$. Hamerow, Restoration, Revolution, Reaction, pp. 38-55, 75, 69, 80, 8182, 83-94. Kamphoefner, "At the Crossroads," 174-201.

26 wittke, We Who Built, p. 193. Carl wittlie The GermanLanguage Press in America, (Lexington, University of Kentucky Press, 1957). In 1840 there were about 40 German-language papers in the U.S. : in 1848 there were 70 and by 1852 there 133 such papers, and by 1860 they had nearly doubled again, (p. 76). See also his description of the conflicts between the grays and greens, pp. 78-80. Wittke, We Who Built, pp. 218-219. Richard o'Connor, The German-Americans, (Boston, Iittle Brown, 1968), pp. 129-154. Walter D. Kamphoefner, "Dreissiger and Forty-eighter: The Political Influence of Two Generations of German Political Exiles," in Germany and America: Essays on Problems in International Relations and Immiaration, ed. Hans $L$. Trefousse, (New York, Brooklyn college Press, 1985), 89-102 argues an opposing view, i.e. that the Forty-eighters and the Dreissigers were alike on important issues. Both opposed slavery, for instance. See also, Bruce Levine, The Spirit of 1848: German Immigrants, Labor Conflicts, and the Coming of the Civil War. (Urbana, University of Ilinois Press, 1992), pp. 15-34.

${ }^{27}$ John Hawgood, The Tragedy of German-America, (New York, Arno Press, 1970), pp. 93-136. Walker, Germany and Emigration, pp. 82-87. Marcus L Hansen, German Schemes of Colonization Before 1860, (Northampton Mass, Smith College Press, 1924), pp. 26-35. 106.

${ }^{28}$ Figures compiled from statistical History of US, p.

29 Walker, Germany and Emigration, pp. 181-194. Wolfgang Kollmann and Peter Marschalck, "German Emigration to the United States," Perspectives in American History: Dislocation and Emigration, the Social Background of American Immigration, VII, (1973), 499-552.

${ }^{30} \mathrm{~K} 81 \mathrm{lmann}$ and Marschalk, "German Emigration," p. 541.

${ }^{31}$ Wittke German-Lanquage Press, In 1873 there were 356 German-American newspapers, by 1883 there were 488 , in 1890 there were 727, and in 1894 there were almost 800, pp. 201, 206-208. Wittke, We Who Built, pp. 210, 211.

32 For a discussion of the unification of Germany and the attitudes of German-Americans see LaVern Rippley, "German Assimilation: The Effect of the 1871 Victory on AmericanaGermanica." in Germany and America: Essays on problems of Interantional Relations and Immigration. ed. Hans $\mathrm{I}$. 
Trefousse, 122-136 (New York, Brooklyn College Press, 1980).

${ }^{33}$ Hawgood, Tragedy, p. 58 .

${ }^{34}$ Hawgood, Tragedy, pp. 79-81. Faust, German Element, Vol I, pp. 577-90.

${ }^{35}$ Hawgood, Tragedy, pp. 79-81. Faust, German Element, Vol I, pp. 577-90.

${ }^{36}$ Faust, German Element, Vol I, pp. 247-249. Josef Roggenbauer, "Uber die Schweren Anfange einer deutschen siedlung in Neu-England aus der Mitte des 18. Jahrhunderts" Zeitschrift fur KuIturaustausch, 19 (Oktober-Dezember, 1969): 298-99.

${ }^{37}$ Faust, German Element, Vol I, pp. 250-51. Roggenbauer, "Schweren Anfange," 299.

38 Faust, German Element, Vol I, pp. 251-252. Roggenbauer, "Schweren Anfange," 299-302.

${ }^{39}$ Faust, German Element, Vol I, pp. 253-259. Roggenbauer, "Schweren Anfange," 299. See also Der deutsche Pionier, 14, (1882), 177, 248-49. Erna Risch, "Joseph Crellius, Immigrant Broker," The New England Quarterly, 12 (June, 1939) : 246-53, 261-267.

Redemptioner was used in the seventeenth and eighteenth centuries to designate an individual who redeemed ones passage through service in America, i.e., indentured servitude. Emigrants had often spent, lost, or paid all their money in tolls and tariffs on the way to the Netherlands, and had no choice but to travel as redemptioners.

40 Faust, German Element, 1:260-61. See also Der deutsche Pionier, 15, (1883), 209.

${ }^{41}$ Karl J. R. Arndt, "Franklin's Lost Map of Germantown, Massachusetts," Pennsylvania Folklife, 31 (1981-82): 87-89. Arndt's description gives credence to the plan for both land speculation and the diversion of German Protestants from Philadelphia to Boston. Roggenbauer, "Schwere Anfange," 299. H. Hobart Holly, "Some Germans of Germantown, Massachusetts, New England Historical and Genealogical Register, 138 (July, 1984), 227-230. Holly adds little new information, but lists a number of genealogical references for "Germantown" in Massachusetts.

42 Harold Jantz, "German Thought and Literature in New England, 1620-1820," The Journal of English and German philology, 1 (January, 1942): 1-45. Jantz makes strong 
efforts to show that prior to 1820 New England intellectuals were interested in German scholarship. This is undoubtedly the case, but is not considered significant for this essay.

43 Faust, German Element, Vol II, pp. 211-215. George $W$. Spindler, The Life of Karl Follen, (Chicago, University of Chicago press, 1917), p. 128. Gustav Philip kBrner, Das Deutsche Element in den Vereinigten staten von Nordamerika, 1818-1848, (Frankfurt, Peter Lang, reprint 1986), p. 158 . John Spencer Bassett, "The Round Hill School," Proceedings of the American Antiquarian Society. New Series, 2 (April 1917-0ctober 1917): 18-28, 37-41.

${ }^{44}$ Faust, German Element, Vol II, pp. 215-217. Spindler, Karl Follen, pp. 81-143. Korner, Deutsche Element pp. 158165. Edwin H. Zeydel, "The Teaching of German in the United States from Colonial Times through World War I." in David P. Benseler, Walter F.W. Lohnes, and Valters Nollendorfs, eds., Teaching German in America: Prolegomena to a History, (Madison, University of Wisconsin Press, 1988), 28-34.

${ }^{45}$ Faust, German Element, Vol II, pp. 164-168. Korner, Deutsche Element, pp. 166-175. Spindler, Karl Follen, 135. Frank Freidel, Francis Lieber: Nineteenth Century Liberal, (Glouster, MA, Peter Smith, 1968), pp, 51-62, for Iieber's career.

46 Jürgen, Herbst, The German Historical School in American Scholarship, (Ithaca, Cornell University Press, 1965 , p. 1. Herbst estimates that 9,000 Americans studied in Germany, and in note 1 , he disputs Thwing's higher estimate. Charles Francis Thwing, The American and the German University: one Hundred Years of History, (New York, Macmillan, 1928), p. 40. Thwing's estimate is 10,000.

47 Faust, German Element, Vol II, p. 211 and Appendix, p. 672. Herbst, German Historical School, p. 19.

${ }^{48}$ Herbst German Historical School. See his chapter on German philosophy and Transcendentialism, pp. 53-72.

${ }^{49}$ Faust, German Element, Vol II, pp. 222-224.

50 A.E. Zucker, ed., The Forty-Eighters: Political Refugess of German Revolution, 1848, Biographical Section, p. 288. Faust, German Element, Vol II, p. 237.

${ }^{51}$ Carl Wittke, Against the Current: The Life of Karl Heinzen, 1809-1880), pp. 1-16, 35-81, 82, 93, 99, 100, 102, $103,105,177$. Zucker, Forty-Eighters, Biographical Section, p. 327. For population figures see Der Deutsche Pionier, 2, 1870. The German born population of Boston in 1865 was 6,465 . 
52 Faust, German Element, Vol II, pp. 260-270. Martha $c$. Engler, "Boston's Era of German Music- -1800 to 1918, in Germans in Boston, (Goethe Society of New England, Boston, 1981), 23-26.

${ }^{53}$ Barbara Miller Solomon, Ancesters and Immigrants: A Changing New England Tradition, (Cambridge, Harvard Unversity Press, 1956), p. 156, n. 9, p. 253. She cites Louisa May Alcott, Little Women, (Boston, 1896) pp. 536-537, 541, 559, $568,581-582$.

${ }^{54}$ Henry Baxter Adams, The Germanic origins of New England Towns, (Baltimore, Johns Hopkins University, 1882), pp. 5, 8-13.

55 Kamphoefner, "'Entwurzelt oder Verpflanzt," " discovered a larger concentration of Germans from saxony in the industrial cities of New Enland than in other regions of the United States. Walter D. Westfalians from Missouri, (Princeton, Princenton Unversity Press, 1987), p. 84, states "Especially striking is the fivefold overrepresentation of Saxons in the mill towns of New England. But they were also heavily concentrated all the way down the East coast as far as Baltimore.... This tendency occurred between 1870 and $1880 \ldots$ [while] in the rest of the country, the proportion of Saxons dropped.... The wave... in the 1880 s included fewer reluctant urbanites and more intentional ones...." Gerhard Wiesinger, Gerhard Wiesinger "Die Deutsche Einwandererkolonie von Holyoke Massachusetts, 1865-1920," PhD Diss, Universitat München, 1990, found a large conentration of Saxons in Holyoke.

56 Frederick A. Bushee, Ethnic Factors in the population of Boston., (New York, Arno Press, 1970), p. 14 . Oscar Handlin, Uprooted, (Boston, Little Brown), oscar Handlin Boston's Immigrants: A study in Acculturation. (Cambridge, Harvard University Press 1959). Stephan Thernstrom, The other Bostonians, Poverty and Progress in the American Metropolis, 1880-1970 (Cambridge, Harvard University Press, 1978) .

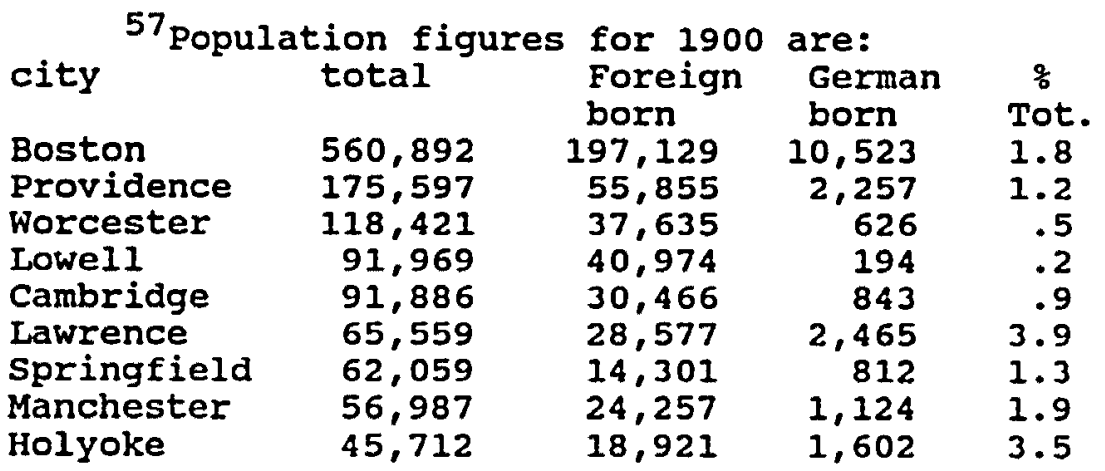




$\begin{array}{lcc}\text { Pawtucket } & 39,123 & 13,087 \\ \text { Fitchburg } & 31,531 & 10,917 \\ & & \\ & \text { German } & \text { f } \\ & \text { parentage } & \text { Tot. } \\ \text { Boston } & 25,119 & 4.4 \\ \text { Providence } & 5,113 & 2.9 \\ \text { Worcester } & 1,706 & 1.4 \\ \text { Lowell } & 464 & .5 \\ \text { Cambridge } & 2,014 & 2.1 \\ \text { Lawrence } & 7,170 & 10.9 \\ \text { Springfield } & 2,021 & 3.2 \\ \text { Manchester } & 3,270 & 5.7 \\ \text { Holyoke } & 4,620 & 10.1 \\ \text { Pawtucket } & 978 & 2.4 \\ \text { Fitchburg } & 484 & 1.5\end{array}$

Source, U.S. Bureau of the Census, Twelfth Census, 1900 , Population, Vol. I, 1901-02. pp. 611-12, 620-23, 627, 641, 796-803, 874-905.

${ }^{58}$ Constance Green, Holyoke Massachusetts: A Case History of the Industrial Revolution in America, (New York Archon Books, 1968), pp. 19-65, 73-74, 106-107. Gerhard Wiesinger "Einwandererkolonie von Holyoke. "In Holyoke's ward 3 the German concentation of $88 \%$ was the highest of any city in Massachusetts. Marianne Pedulla, "Labor in a city of Immigrants: Holyoke 1882-1888," Historical Journal of Massachusetts, 13 (1985): 147-61.

${ }^{59}$ Raymond L Sickinger and John K. Pirmeau, The Germans in Rhode Island: Pride and Perservance, 1850-1985, (Providence, The Rhode Island Heritage Commission, 1985) pp. $4,5,6,14,17,18,20-22,25-27,28-35,36-47$.

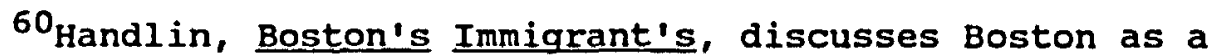
commerical center rather than an industrial or textile center, pp. 54-87. Handiin's figures on the number of Germans, (Table VI, p. 243) shows that German's increased after 1865. Thernstrom, The other Bostonians, p. 131 note 4, with regard to the types of professions of Germans. 
CHAPTER II

\section{GERMANS IN AMERICA'S CITIES}

During the late nineteenth and early twentieth centuries almost every immigrant group settled together in neighborhoods forming the little Germanies, little Italies, little Polands, and Chinatowns which characterized American cities. Since during the nineteenth century, most workers lived within walking distance of their jobs, working class and ethnic neighborhoods developed in cities near the docks, warehouses, and factories. To some scholars these labor and ethnic enclaves were a response to the new situation in America. In them, the immigrants attempted to buffer themselves against outside forces. In the enclaves, they attempted to maintain the old culture and attempted to recreate the support systems of the old villages in an urban setting. 1 Until the end of the nineteenth century, Germans were the largest group speaking a foreign language in the United states. They were among the first to settle together creating distinctive enclaves. 2 In fact in some city wards Germans were seventy percent of the population. 3

From Germantown in Pennsylvania, in 1683, to Manchester and Lawrence, in the 1880s, and in Milwaukee and Chicago in between, Germans "established a distinctive district in almost every American city."4 The resident of this district, 
speaking German, could shop in German stores, eat in German restaurants, drink in German taverns and beer gardens, obtain services from German banks and insurance agencies, have his medical needs cared for by German physicians, dentists, and pharmacies, have any legal problems attended to by German lawyers, work in German companies, attend a German church, and be buried by a German undertaker. He or she could attend German theater, opera or musical performances, and buy German books and newspapers. The resident could join German clubs and mutual aid societies and attend lectures, dances, festivals, and musical performances of a multitude of clubs in their halls. The very nature of the district and the life within it would be expected to preserve German ethnicity. However, the fact of life in a city with its multitude of non-German residents and the necessity to work and conduct commerce in English led to the eventual end of a separate ethnicity and the German neighborhood.

Hermann Hagedorn (1882-1964), the biographer of Theodore Roosevelt, gives a compelling description of the total Germanness of sections of New York. He and his siblings may have spoken English to their mother but they spoke German to their father and at meals. He described both his home and locale as, "a German world...as German as Bingen on the Rhine." It was "German speech, German music, German servants, German food, and German festivals."5 since all social contact was with other Germans, he clearly remembered meeting 
children of a non-German neighbor for the first time. Hagedorn's father was essentially a transplanted German and he tried to create a transplanted family in a transplanted little Germany. It is not hard to imagine others living as transplanted families. However, in 1963 when Glazer and Moynihan studied ethnicity in New York they found that "the Germans as a group are vanished." 6 Another historian concluded that the "impressive [German] urban enclaves are now largely a matter of historical record."7

How could such vibrant ethnic communities disappear? In order to answer this question and to relate it to Manchester and Lawrence, important facts about the major German-American communities must be presented. The growth, strength, and make up of the German-American communities in American cities are relevant to an understanding of those in the two New England cities. The occupational and class levels of the German-Americans in cities can be compared to those in Manchester and Lawrence. The German regional origins of the immigrants influenced many aspects of German life, including the degree of their cooperation within the cities. The effects of outmigration, the events of World War $I$, and the Nazi regime are important for comparisons and contrasts to the Germans in Manchester and Lawrence. In order to understand fully the Germans of Manchester and Lawrence some important factors associated with the Germans in the major American cities will be summarized. In the nineteenth century Milwaukee earned the 
reputation as the most German of cities. By 1860 , Milwaukee had grown from a tiny frontier outpost to a city of 45,000 irhabitants, of whom almost 16,000 , or thirty-five percent were German. In 1900, Milwaukee had 285,000 residents, and German-Americans (those born in Germany and of German parentage) numbered 146,846 or fifty-one percent of the total, 8 giving it the largest percentage of German-Americans of any city in the United States.

Milwaukee's founding and the opening of Wisconsin to settlers coincided with the arrival of the Forty-Eighters. Immigrants attracted to the farm lands of Wisconsin also helped Milwaukee grow. Although many settled the land, others failed as farmers and moved back to the city. Still others either ran out of funds to move further inland or saw opportunities in providing urban services on the frontier. 9 As early as the 1840 s guidebooks published in Germany informed prospective emigrants of the "German 1ife" in the city and the best transportation routes to Milwaukee. Additionally, German churches actively influenced immigration. Reports from leaders of Lutherans to Germany stimulated emigration. During the 1840 s Milwaukee's first Roman Catholic Bishop, Swiss born John Henni, actively recruited Catholic settlers and priests. Finally, the state itself attempted to induce immigration by establishing the office of the Commissioner of Emigration. 10

Milwaukee quickly became a city of ethnic enclaves, since "the Germans avoided the Irish and, almost everyone 
avoided the Germans, and the British and Yankees sought out one another."11 The Germans first settled in the northern and western parts of the city and these sections became increasingly German. Moreover, "German Town," soon became "not so much a single neighborhood as a microcosm of the city as a whole, with its downtown, its central area of mixed shops and residences, its exclusive sections, and its extensive suburbs of small wooden homes and shanties."12 The very Germnan-ness of Milwaukee attracted many German settlers, who consciously chose to live among other Germans in order to ease the transition to American life. Kathleen Neils Conzen also notes that upwardly mobile Germans still tended to live in German areas, unlike upwardly mobile Irish. Further, the relatively few wealthy Germans chose to live among the wealthy natives. In conzen's view the patterns of settlement in Milwaukee did not fit the classic ghetto hypothesis. 13 That is, the Germans did not move out of the German enclave and up into middle class neighborhoods.

Almost as soon as enough Germans arrived in an area, they formed clubs, or Vereine ${ }^{14}$, and Milwaukee was no exception. In Germany, Verein members were mainly the urban middle class and lower middle class. Since, in Conzen's view, the German settlers in Milwaukee were not peasants, but had been the middle and lower middle classes of Germany, they transferred their clubs to America. Furthermore, in Milwaukee the club members were mainly middle class, and their leaders were the professionals, shopkeepers, and 
artisans. ${ }^{15}$

of all immigrant groups, Germans were particularly noted for the number and variety of their societies. One of the first founded, and often the most influential and usually iiberal, was the Turnverein, a gymnastics society. Native Bavarians, or Württembergers, and so forth, often joined together in Landsmannschaften, or provincial societies. Everywhere they went Germans had a reputation for forming singing societies and bands, and there were several in every city. Germans usually joined together in mutual aid--sick relief, old age, or death benefit--societies. The more middle class members joined the fraternal Hermann Sons or the order of the Harugari. The shooting clubs popular in some parts of Germany were also duplicated in America. Additionally, religious denominations usually formed their own societies, and workers and Socialists sometimes formed separate units of these societies. Most clubs had a hall for entertainment, festivals, meetings, eating, and drinking. One of the stated purposes of almost every verein was the preservation of German language, culture, and customs. Conzen also believes that Vereine had a role in the immigrants adjustment to America. The clubs preserved similar forms of social interaction but also eased the immigrant,s transition to America. Paradoxically, in Conzen's view, one cannot correlate the sheer number of German clubs and their events to the strength of the community. She believes that the number and diversity of the clubs could 
hasten the dissolution of the community since a united front was not possible. 16

Perhaps, no immigrant group had so many divisions as the Germans. Many immigrants thought of themselves as Rhinelanders, Bavarians, or Württemburgers, rather than as Germans. Furthermore, Germans divided along religious lines. Catholics and Lutherans brought animosities from Germany to America. The smaller Protestant sects avoided both. Jewish Germans also separated from others on the basis of religion. Free Thinkers disdained religious groups of all kinds. The Free Thinkers fell into several categories; the anticlerical, those who practiced a form of secular or rationalist religion, and the complete non-believers. often the Free Thinkers were the organizers and leaders of many of the Vereine, especially the Turnverein.

For example in Milwaukee, Catholics, Protestants, and Jews formed their own separate societies, singing clubs, and mutual benefit associations. The catholics, under the direction of Bishop Henni, established hospitals and orphanages. The Protestants concentrated on operating a German school.17

In the secular arena, other associations attempted to foster a German community identity. A German fire company and the German Association for Education and Entertainment formed. A city wide relief society, the Deutsche Unterstützungs-Verein, was founded in 1846. The more freethinking members of the community formed the Freie 
Gemeinde, which later merged with the Workers' Reading and Educational Society, and the Sozialer Turnverein. By the mid 1850s, the rather progressive Turnverein, which had gymnastics classes for girls, became the center of intellectual life for the German citizens. In 1857, the Milwaukee Turners hosted a midwest Turnfest. 18 such regional competitions became common among Turner and singing societies. Even those in the industrial cities of New England organized regional competitions and events. The German clubs in Milwaukee were representative of German Vereine.

Two particular features of mid-nineteenth century Milwaukee deserve mention. Not only did the Lutherans and Catholics operate parochial schools, but the city's Free Thinkers also formed their own school, the Milwaukee-schulVerein in 1851. The positive aspects of Deutschtum were overshadowed by the virulent anticlericism of the period. Forty-eighters were blamed for a number of bitter attacks on clerics and church practices.19 such attacks further divided the German community of Milwaukee.

The divisions among Milwaukee's Germans may have hastened their assimilation. According to another scholar "by the 1880s [Milwaukee's] Germans were usually thought of as separate from other immigrant groups--almost as if they had gained the stature of native Americans."20 Also by the end of the century they had moved into most areas of the city. In spite of their numbers the Germans were 
"influential," but not "leaders in Milwaukee's economic, political, religious, or social life."21 conversely the Germans dominated the labor movement in the city. ${ }^{22}$ At the start of World War I, Milwaukee's Germans supported strict neutrality. The wives of a number of industrial leaders organized bazaars to raise funds for German war relief. After the United States entered the War, German-Americans served as members of the Council of Defense and on Liberty Bond drives. Despite the acceptance of the German-Americans in Milwaukee, the prominence of several in local industry, and their involvement in patriotic activities, Milwaukee experienced war-related superpatriotism. This included such silliness as the group of patriots who set up a machine gun in front of the Pabst Theater to prevent a performance of Wilhelm Tell. 23

Chicago also became identified with German-Americans. Growing from a small frontier settlement it became the major industrial, commercial, and transportation center of the Midwest. In 1850 when the population of Chicago was 29,963 there were 4,757 German-born residents, or about sixteen percent of the total. By 1860 Chicago's population had grown to 109,206 of which 22,230 were German-born, or about twenty percent of the total. In 1900 the city's population of $1,698,575$ contained 170,738 German born, or almost exactly ten percent. However, in 1900 the total German-American population, (those born in Germany and those born in America of German parents) was 440,000 or almost twenty-six percent 
of the population of the city. 24

By the 1840s a German neighborhood had developed on Chicago's North side. Initially those living there were mainly Bavarians and Württembergers. By the 1880 s German neighborhoods began to develop on the northwest and southwest sides. Immigrants from Mecklenburg, Pomerania, West Prussia and Brandenburg settled mainly in the northwest neighborhood. Apparently the origins of those settling in the southwest neighborhood have not been as exactly determined. At the same time the North side became the neighborhood of the more professional and middle-class Germans. Additionally, according to Hartmut Keil and John Jentz, skilled workers tended to live in close proximity to each other, irrespective of nationality, whereas unskilled workers and individuals from rural areas tended to cluster by nationality or region. 25

In many cities Germans often held-high skilled jobs and operated small business, but in Chicago the proportion of unskilled workers among the Germans was very high. For instance, in 1900 over twenty-five percent of all German heads of household were unskilled. Conversely, the skilled German workers dominated such crafts as shoemaking, tailoring, cabinetmaking, carpentry, blacksmithing, wagonmaking, butchering, baking, and brewing. over they years, mechanization forced a number of the skilled workers into semi-skilled factory jobs. There was a definite regional correlation to the skill levels of the German 
workers. Only fifteen percent of immigrants from the northeastern provinces of Germany were skilled workers, whereas almost two thirds from the industrialized regions of Silesia and Saxony were skilled workers; and the skilled cigarmakers who had learned their trades in Germany came from the southwestern and northern parts of Germany. Also important to the development of the neighborhood and adding to the growing lower middle class, were the small-business people and retailers. 26

Chicago's German societies divided along definite class lines and by neighborhood. For instance, both the middle class and the working class had their own Turnverein. In Chicago, the working class tended to join the fraternal orders of Harugari and the order of the Sons of Hermann, while middle class Germans tended to join the more Americanized Free Masons and the order of Redmen. 27 Duplicate German societies developed in each of the German neighborhoods--the North side, the northwest and the southwest. The small entrepreneurs, who were far fewer than the workers dominated the clubs. The apparent strength of the German community was partially an illusion, since the number, class divisions, and neighborhood base of the societies made real unity difficult.

The religious, political, and social differences among Chicago's Germans were well defined. In 1880 there were several Roman Catholic parishes, Lutherans (with several divisions), Baptists, Adventists, Methodists, a Jewish 
congregation, and free thinkers. Germans belonged to the Democratic and Republican parties, as well as to the Social Democrats, Socialists, and anarchists. By one estimate Catholic Germans outnumbered German Lutherans almost two to one. These two major denominations had their own Vereine separate from the secular Vereine. ${ }^{28}$

In addition to the already recognized divisions among Germans, there was perhaps yet another group, the Kneipendeutschen, or tavern Germans. The numerous taverns became centers of neighborhood communication, job referrals, and meeting places, especially for labor groups too poor to afford their own hall. For instance, two of the larger taverns, Neff's Hall and Grief's Halls had separate meeting rooms for the workers. During the week the beer halls and meeting rooms were frequented by the men. On the weekends they became classic beer gardens complete with bands, and catered to the entire family. The importance of the taverns is illustrated by the fact that in 1880 , forty-three percent of the city's saloon keepers and bartenders were German. According to Klaus Ensslen the saloon became an important gathering place for the working-class family, ${ }^{29}$ those who may have been too poor to pay dues to the more established Vereine. Therefore, temperance crusades assumed threatening importance to the German-American community. Temperance became an ethnic and a class issue.

The richness and diversity of Chicago's German culture in the early Twentieth Century was quite extensive. Chicago 
had two daily German language newspapers, a German orchestra and opera house, and over 400 German societies and clubs. Despite such strength, Leslie V. Tischauser concludes that between 1914 and 1919 this German culture was all but destroyed and that attempts to revive it between 1919 and 1941 were unsuccessful. 30

According to Tischauser, war tensions compounded by internal divisions manifested in local politics fractured the German community of Chicago at the very time it needed to be united. In the mayoral election of 1915, Democrat Robert Sweitzer managed to get only thirty-four percent of the German vote in his loss to william Hale Thompson. Sweitzer, a Catholic, could not get the vote of the Missouri synod Lutherans, for whom "religion was far more important...than ethnicity."31 According to Tischauser the election was proof that nothing--not the war, not German ethnic pride, nor political power could unite Chicago's German-Americans.

World War I was a curious time in Chicago. Mayor William Hale Thompson, who in the 1915 election was perceived as pro-British, now appeared pro-German, and allowed chicago to become a center of anti-war activity. At the same time, the nativist American Protective League gained strength in Chicago. Public pressure on Germans to display complete loyalty increased. Leaders of the Chicago branch of the German-American Alliance urged loyalty as a means of preserving Germanism for the future. The German club changed its name to the American Unity Club and the Germania club 
changed its name to the Lincoln club of Chicago. Cardinal Mundelein, a third-generation German-American, used the war to Americanize his diocese and demonstrate the loyalty of Catholics. The Lutherans were more intransigent, refusing to teach "Americanism" in their schools, and conducting services in the German language. 32 In those trying times, the denominations still went their separate ways.

Melvin C. Holli presents a contrasting analysis of the German-Americans and the anti-German attacks in Chicago. A pro-German demonstration on August 5, 1914 attracted a crowd of 4,000 to 5,000 who listened to boisterous speakers, pledged funds for Germany, and loudly paraded. This display left non-Germans uneasy. Some of Chicago's Germans followed up with ethnic slurs about slavs and proclaimed general support of Germany's war aims in Eastern Europe. Later, such sentiments would harm them greatly. Harvard Professor Hugo Munsterberg increased tensions by veiled references to undesirable immigrant groups at the unveiling of the Goethe statue in Chicago in 1914.33 In Holli's view the "GermanAmericans failed to draw a distinction between intrinsic German culture and the German Empire of Wilhelm II."34 If the Germans alienated the eastern Europeans, they found a new ally in the sometimes formerly disliked Irish. German and Irish groups joined in common cause. According to Holli, "in Chicago's multiethnic mosaic, the combination of these two ethnic superpowers, celt and Teuton, was enough to make any 
Anglophile quail with trepidation." 35 After the entry of the United states into the war, the Poles, Bohemians, Czechs, and other ethnics got back at the Germans. They led the efforts to de-Germanize Chicago from the changing of street names to the ending of German language instruction in the public schools. They were quietly supported by Anglo-Americans. Chicago's wartime Americanization campaigns had not touched the Slavic, Southern, and Eastern European citizens. 36

After the war local politics mirrored pre-war campaigns and Germans were still not a powerful voting block. The 1919 mayoral election was a replay of the 1915 election between Republican Thompson against Robert Sweitzer, who now claimed to have been born Irish. He claimed that his mother, widowed when he was an infant, married a German who adopted him. It did not matter, for he still lost the election. Again the "German vote" was divided along religious lines. 37

After that experience, apathy characterized Chicago's German-Americans during the 1920s rather than political or cultural activity. In the 1923 mayoral election the German candidate again could not garner a majority of the German vote. The German-Americans remained divided by class, religion, and politics, and could find no common foundation to rebuild their ethnic identity. Later in the decade German leaders seeking to improve their image became involved in political fights over the content of school textbooks. Convoluted hearings regarding the pro-British and anti-German bias of history books soon involved Mayor Thompson for his 
political purposes, and the other immigrants, such as the Italians, who objected to the way they were portayed in the texts. According to Tischauser, this only accomplished a further reaffirmation of the "caricature of a stubborn 'Teuton. " 138

Meanwhile, according to Tischauser, at the end of the war, the German Verein had little difficulty re-establishing themselves, and the smart ones stockpiled liquor before prohibition went into effect. This, undoubtedly, helped liven up social events. It is also Tischauser's view that the German-American leaders were determined not to allow their community to disappear, since their very economic survival and leadership positions depended on the GermanAmerisan community. Also in the early 1920 s relief efforts for Germany revived the German clubs and renewed hopes for unity among German-Americans. The first "German-Day" after the war was held in 1921 organized by the German-American citizens League. The successes of this day led to plans for a city-wide German Federation. After the United States and Germany signed their separate peace treaty in 1922 , the American Unity club changed its name back to the German club of Chicago. The Missouri synod of the Lutheran Church rejected calls for unity, attempting to preserve religious doctrines and German language. 39

Nazi rule in Germany continued the splits in Chicago's German-American community. The Missouri synod of the Lutheran church apparently was favorably disposed toward 
Hitler. According to Tischauser, the anti-Nazis were associated with the Turner movement or the more liberal Germans. Attempts were made by the more pro-Nazi groups and the Missouri Synod to support Landon over Roosevelt in the 1936 election. Such attempts failed as Roosevelt received over 658 of the German vote in Chicago. In 1937, Cardinal Mundelein spoke out against the German government. However, the independent, German-language newspaper, Abendpost, refused to attack Germany's internal policies. GermanAmerican leaders in Chicago were reluctant to attack Hitler but were unwilling to join the Nazi German-American Bund. The Chicago, the renamed Germania Club, under the leadership of Dr. George Scherger, a Lutheran minister, publicly praised Hitler. On balance, the German-Americans of Chicago were unwilling to suffer a repeat of 1917-1918. In 1940, feeling the possibility of renewed attacks Chicago Germans created a united front, Einheitsfront. only two Chicago groups, the German-American League for Culture and the German-Americans for Democracy, publicly fought against Nazism. The nomination of Wendell Wilkie, a German-American, gave the leaders hope against the seemingly more pro-British Roosevelt. Once more, Chicago's German-American voters overwhelmingly supported Roosevelt with seventy percent of their votes. Tischauser concludes that the German-American leaders were out of touch with the average German-American citizen. Tischauser suggests that the pro-Hitler support of some of the leaders was an embarrassment to the average 
German-American citizen. 40 This would further suggest that the German community--as a place apart--no longer existed. Chicago experienced an attempted revival of Germandom in the 1960s and 1970s when the German-American-National Congress (D.A.N.K.), headquartered in Chicago, planned celebrations. Most of the leaders of this group were Germanborn, had emigrated after 1945, and had little association with other German-Americans. of all contemporary ethnic revivals in Chicago, the Germans have been the least successful. Tischauser concludes that the want nothing more to do with their German heritage. 41 In a sense they had truly been devoured by the melting pot.

Cincinnati also became associated with German-Americans. By 1890 the German population (c. 170,000) of Cincinnati was more than fifty-seven percent of the city's total population of 296,908. Thereafter, the proportion of Germans to the total population declined, but in 1910 one-half of the population was German or German descent, and one-third spoke German. Mirroring German emigration patterns, at the start of the nineteenth century most Cincinnati Germans were from southwestern Germany, but by 1900 most German-born residents of the city were from northeastern Germany. 42

Within the city, Germans were settled in an area known as "Over-the-Rhine," named for an old barge canal, a tributary of the ohio River, locally called the "Rhine."43 According to one historian, an immigrant arriving directly in Cincinnati from Germany would feel almost at home--hardly in 
a strange new land at all. He might even find that his own dialect was spoken. The religious life of the Germans was exceptionally diverse (11 German Protestant Churches, 12 German Evangelical, 3 Lutheran, 6 Methodist, 4 Presbyterian, 2 United Brethren, 1 German Baptist, and 34 Catholic parishes, which were mainly German). 44 In addition there was a multitude of clubs and every saloon-keeper hosted at least one German society. 45

The lasting power of the German societies is sometimes questioned. In the opinion of Guido Dobbert, they seldom lasted longer than the generation which founded them. The astonishing diversity of the Vereine may have been a factor. There were over one hundred Vereine before the first World War. only the churches were considered strong enough to last. In cincinnati, however, there were two powerful and long lasting clubs, the Turnverein and the Deutsche-pionierVerein von cincinnati. The latter, established in 1869 , published the historical journal Der Deutsche pionier from 1869-1887. It attracted the most prominent of cincinnati's Germans, and it boasted up to 1,000 members just before World War I. 46

Germans in cincinnati had been particularly effective in introducing German language instruction in public schools. First made available in 1840, there were still 17,000 students studying German under the tutelage of 175 teachers in 1915. 47 Despite that seemingly impressive number, there were actually fewer students than in earlier times. Dobbert 
concludes that there was a "near-hysterical defense of the mother-tongue and an equally indifferent and apathetic attitude toward it."48 To Dobbert, there was a logical explanation. The language that was being defended:

was the language of the educated and the upper classes: the university graduate, the higher government official, the financier, the nobleman, and the commissioned officer. It was the language of Goethe and Schiller, more written and read than actually spoken, and spoken only by those to whom, by virtue of their training, tongue and pen it had become interchangeable... The vast majority of the German people, and especially the ones customarily filling the steerage of trans-Atlantic liners, spoke an infinite variety of colorful and earthy dialects....

In Germany Hochdeutsch had been a necessity. In the United States it became a luxury, though not always an entirely useless one.... In all likelihood the average immigrant could ill afford to spend his time and energy in acquiring a faultless

Hochdeutsch and at the same time learn the

English essential for his making a living. 49

Dobbert further suggests that the average German communicated with Germans from other regions in a mixture of Hochdeutsch and English. Dobbert believes that the average German immigrant realized that the only way for him and his children to get ahead was to learn English. The attempts of the selfappointed leadership to preserve a language that the average German considered dead, was an indication of how out of touch those leaders were. 50 It is important to note that the leadership is most likely to leave records of its thinking through neswpapers, speeches, or cultural or political functions. The average German-American left very little documentation. Only the number attending the events or voting records may show how they were acting or thinking. 
In the early years of the twentieth century the Germans of Cincinnati attempted to become more united. Two newer, supposedly more all-encompassing German Societies gained prominence, the Deutsche Tag-gesellschaft (German Day Association) and the Deutsche stadtverband (The German city union). They joined the older Pionierverein, Deutsche Literarischer KIub, and the cincinnati Turngemeinde, a federation of the Turner societies. Their common thread was to criticize prohibition, which was considered an attack on personal liberty and the financial success of the Vereine. This common goal could not prevent jockeying for power and influence between the various organizations. 51

With the outbreak of World War I, Cincinnati's Germans reacted much the same as Chicago's. There was initial enthusiasm, followed by efforts to sway public opinion to the German cause. The clubs organized war widow and orphan relief events for Germany, and encouraged efforts to deliver votes to the Republican presidential candidate, Hughes. But, Wilson carried the state in 1916, which damaged the prestige of cincinnati's organized "Germandom." However, Cincinnati's German community achieved its greatest unity during 1916 when it set raised funds for relief in East Prussia. Dobbert estimates that the hard-core "Germandom" was probably a little more than eight thousand or about one-fourth of cincinnati's adult males of German stock. The majority $(79.4 \%)$ of the officers of the various German societies had a decidedly lower middle-class background. Yet Cincinnati's upper class 
Germans assumed leadership of the Kriegshilfe activities of 1916. Among those represented were Mrs. Howard Wurlitzer of the famous musical manufacturers, Edward Brunhoff, president of the Brunhoff Manufacturing Company, John Shearr, president of the Ohio Mechanic Institute, and Judge A.K. Nippert, who was married to Maude Gamble of the Proctor \& Gamble Soap Company. It was also at this time that German Catholics and protestants united for the first time to found an orphan society. Such German unity did not prevent the Catholic Archbishop Moller from reducing the use of German in the parishes and catechisms. 52

Despite the fact that the city had once been over half German, World War I did not spare the Germans from indignities. In 1918 German language instruction in the public schools ended and the teachers were fired. Street names changed; Bismarck to Montreal, Berlin to Woodrow, Bremen to Republic, and Brunswick to Edgecliff. The German Mutual Insurance Company thought it better to be known as the Hamilton County Insurance Company and the German National Bank thought depositors would find Lincoln National Bank more appealing. The Altenheim became the cincinnati old Mens' Home. The majority of non-German Cincinnatians approved the anti-German hysteria of the extremists. 53 Tolzmann strongly suggests that this hysteria was used by certain AngloAmerican political elements to regain political control of the city from Germans. 54

According to Dobbert, the anti-Germanism left the 
Vereine and cincinnati's Germans dispirited and disrupted. Another blow to club activities was the influenza epidemic of 1919-1920 and Prohibition. Further, the respected volksblatt ceased publication in 1919.34

Historian Don Heinrich Tolzmann takes the opposite view that the German-American community continued and was active after World War I. The German clubs not only continued to operate, but they actually gained members, and pre-war club officers continued to lead them after the war. In 1926 the American Citizens League (ACL) which emerged from the dissolved German-American Alliance sponsored a German Day celebration, German language instruction, and a Kinderchor. The Turngemeinde remained as a strong organization and supported a German Sunday School and German language instruction. The venerable pionier-Verein continued to be the premier German-American organization. Membership was extended to German-Americans (not just natives of Germany) with a command of German. During the 1920 s membership averaged about 925 per year with some years over 1,000 members. However, membership was declining toward the end of the decade. 55

During the 1920s, Cincinnati's Germans supported sixtyfour different Vereine. Additionally, recently arriving immigrants formed new Vereine. Most numerous among them were Danube Swabians, groups of Germans who had lived in small communities outside of Germany in southeastern Europe. Coming from isolated and closed communities in Europe they 
infused new ideas of preserving the German heritage in Cincinnati. Also arriving were the Reichsdeutsche, individuals from Germany who were escaping the bleak economic conditions there. 56 otherwise, Prohibition reduced both attendance at Verein-Hallen and Feste, and the income of the clubs. 57

However, the clubs associated with religious denominations thrived the best. For instance, clubs associated with the Catholic church continued to flourish, and there were eighty Catholic Vereine with about 12,000 members. By the 1930s, however, the language of these organizations was English. The German-Jewish community in Cincinnati was rather large and strong. After World War I, the German Jews remained active both in their various Vereine and especially in the pionier-Verein and the German Literary Club. 58 Tolzmann concludes that "the German-American Community along with its various institutions survived the war almost fully intact, but altogether less vocal and visible than before the war." 59

The leadership of Cincinnati's German-Americans remained relatively constant from 1914 into the 1920s. Bavarian born John Schwab associated with the Cox Republican political machine was later appointed a judge. He always maintained his connection to the German clubs and was an officer in a number of them. Alfred Nippert, born in Frankfurt am Main, who earned an L.L.B from the University of Cincinnati and later served on its board, became a judge 
of the Common Pleas court. His wife, Maude Gamble, was the daughter of James B. Gamble of the soap company. Lübeck born, H.H. Fick was the cultural leader of the German community. He became the supervisor of German instruction in the Public schools in 1903 and gained a national reputation in education. These pre-war leaders of cincinnati's Germans continued to lead them after the war. For instance, it was Schwab's idea to resurrect the German-American Alliance as the American Citizens club. 60 The continued leadership of these three shows a remarkable continuity in the GermanAmerican Community.

Tolzmann concludes that the German-Americans "survived the war but had been deeply hurt," resulting in a "redefinition of German-Americana ethnicity."61 There were four major factors of this redefinition. First, the status of the German-Americans had been reduced by the war, and a stigma was associated with everything German. This began to fade toward the end of the 1920s. Secondly, German-Americans began to privatize and subdue their ethnicity. Third, the war had diminished and diluted the political influence of the German-Americans. They lost access to the machine and the German-American leadership became politically neutral. Finally, the German language lost its importance. Cincinnati's German leaders now accepted both English and German. 62 Tolzmann's conclusions show a tension between continued Deutschtum and Americanization. It would appear that by the end of the 1920 s some of cincinnati's Germans 
were Americanized, some, especially the newer immigrants were still German, and some were still between the two. Finally, residents moving out of the "Over-the-Rhine" district hastened the decline of that German enclave. Tolzmann warns against false conclusions about diffusion through the city. He attempts to show that those who moved out retained ties to the old district and returned at times to partake of German culture. He also argues that many resettled in particular neighborhoods, especially on the west side of the city, thereby transferring Deutschtum. 63 In fairness, these arguments are not fully developed, but they seem tenuous. The outmigration plus the four points he elaborates eventually doomed Deutschtum in the "Over-the-Rhine" district.

Attention will now be turned from a German city in which Deutschtum survived the war to one in which two historians consider it to have been totally eliminated. Furthermore, those historians consider that the only thing German about st. Louis was beer, and that not even all the beer in st. Louis could save its Deutschtum.

The common contemporary association of "German" st. Louis may come from the Busch brewing interests, but historians also remember the vigorous campaigns of the Germans, especially the Turners, to save Missouri for the Union. 64 As an outpost of New France, st. Louis first had a strong French character, but after the Louisiana purchase it attracted Yankee traders and speculators, the Irish, and the 
Germans. By 1900, the 199,182 Germans made up approximately thirty-five percent of the 575,238 residents of St. Louis. 65

Unlike other cities, however, Germans were not concentrated into one ethnic enclave. 66 According to Audry L. Olson, the German immigrants were found in neighborhoods on both the north and south of st. Louis, and in these neighborhoods the Germans were interspersed with natives and other immigrant groups. Consequently, there was never any homogeneous German community in St. Louis. She further concludes that the only community that may have existed was perhaps a community of culture and custom. German language classes in St. Louis schools were designed to hasten assimilation, unlike cincinnati's which fostered divisions. Furthermore, the separate classes were eliminated in the 1880s, well before the crisis of World War I. The introduction of German classes on Saturdays around 1909 proved to be unsuccessful. ${ }^{67}$ Therefore, disinterest in the German language hastened assimilation.

other facets of German life in St. Louis confirmed this trend. In their churches English overtook German, and only two German language newspapers remained in 1915 even though the German population may been about 200,000. Typically, among Germans numerous religious denominations existed. Additionally, there were over 300 clubs just prior tc World War I. Olson concludes that the clubs were too numerous, too small, and too weak to be effective. Further, the clubs were duplicated in each of the neighborhoods. Membership in the 
clubs by and large represented the middle class. Of the various clubs, only the Turnbezirk was large enough to organize and represent the other groups. In 1911, the st. Louis Turnbezirk had about 5,000 members. But, the clubs were growing weaker, especially since the second and third generation German-Americans were not joining. Consequently, they were unable to transmit Deutschtum.. Furthermore, the very success of the Turners in introducing gymnastics into the public school curriculum, reduced the attractiveness of the Turner classes, usually held after school or on Saturdays. 68

According to both olson and David Detjen das Deutschtum of st. Louis centered around a keg of beer. According to Olson:

A large keg of beer...helped to make a success of German celebrations. It may seem unlikely that a way if life would resolve around a $\mathrm{keg}$ of beer, but without it the Deutschtum lacked a rallying point to which it could adhere.

The Germans in St. Louis enjoyed a celebration. Most of them were probably not consciously thinking of cementing Germang unity, but just enjoying Gemütlichkeit.

or as Detjen reports:

The average German-American was undoubtedly more concerned about preserving his Verein's and his local tavern's right to serve beer on sunday than with the performance of schiller in the local theater or the publishing of local German-American histories. 78

Olson concludes:

The preservation of the mother tongue was not ordinately sought by the average German American.... There was no unanimity in political affiliation, no single religious denomination, and a multiplicity of 
societies.... But the societies did provide proof of the only type of German community that existed in the city. The Germans could talk with pride about their way of life, meaning their penchant for joining societies and enjoying Gemutlichkeit.... They were ready to support the only thing they valued... Gemütlichkeit. 71

If the assessments of such limited perspective are true, then there was little of substance in the German-American community in st. Louis. It could neither adjust to opportunity nor survive challenges.

Not even World War I united the German-American Community in st. Louis, according to olson. Widows and orphans funds and collections did not generate much support. In October, 1915, st. Louis German-Americans united for the only time and for their largest event, a bazaar to raise funds for Germany. The Busch family booth, which was the most elaborate, attracted considerable attention. The unity of the bazaar, according to olson, "vanished with the last piece of crepe paper on the bazaar booths."72 At the same time, however, both the Verein life and German life continued during the war. 73

After the war, however, Prohibition "touched the Germans where it hurt the most... in their enjoyment of Gemütlichkeit...giving them their only cause for unity."74 or as Detjen phrases it, "Prohibition...gave German-Americans a common foe, which created a solidarity... within the GermanAmerican Community that had never existed before."75 In addition, the brewery interests of the city had much to fear from Prohibition. In 1910 twenty-three breweries employed 
over 5,000 workers and sold over twenty-three million dollars worth of beer. Prohibition adversely effected the GermanAmerican community in St. Louis. In 1924, one German language newspaper folded, probably partially as the result of lost advertising revenues, while the other struggled until 1938. The Vereine began to have problems. Membership declined due to a lack of new immigrants, the deaths of older ones, and the disinterest of younger German-Americans. Gemütlichkeit, the "only unifying aspect of st. Louis Deutschtum withered away with the drying up of beer."76

The historians of st. Louis concluded that the city's Germans had been assimilated as the result of several factors. There very disunity meant that each separate subgroup was detached from the whole and assimilated. Since the Germans did not reside in a single enclave, they could not collectively ward off assimilation. The events of World War I and the uninspired leadership of the German-American National Alliance hastened the demise of the city's Germans. Finally, their only sense of unity was Gemütlichkeit, which was a weak foundation upon which to base ethnic pride. 77 In these analyses there seems to be too much emphasis on the keg of beer and not enough on the other assimilating factors.

In addition to midwestern cities, Germans settled in eastern cities, especially the two largest cities in New York state. Certain characteristics of the Germans in Buffalo and New York City merit discussion.

One route from the port of New York to the Midwest went 
through Buffalo. Many Germans settled in Buffalo, either to take advantage of available opportunities, or because they had exhausted their travel funds. In 1855 the approximately 18,000 Germans in Buffalo's population of 74,000 lived mainly on the east side of the city in a one and one half square mile area. By the 1880 s German-Americans comprised about half of the city's population, and its "monolithic German village...gave it a type of insular cohesiveness not found in other major centers of German immigration."78

As early as 1855 the German population of Buffalo was large enough to support three German language newspapers, one of which Die Aurora was Catholic. ${ }^{79}$ According to Andrew Yox, the Catholics were the largest and best organized of the subgroups. They had a branch of the Catholic central Verein and five parishes. 80 This could be expected since in the 1850s, Bavarians and other southwestern Germans were predominant among the Germans. 81 They were so numerous that Yox states that "Bavarians represented the German village" 82 Soon, however, Germans from the north and east began to take control of Deutschtum in Buffalo, setting off regional and religious conflicts. The founding of the freie presse, in 1860, by a Thuringian family heralded the change. In 1871, neither Catholics nor Lutherans participated in a parade honoring German unification, 83 indicating conflicts between church and club Germans, between the denominations, and between Germans from different regions.

Being typical Germans they soon formed Vereine. Certain 
facts about the clubs in Buffalo bear mentioning. The leaders of the Vereine were all born and educated in Germany. Interestingly, a set of brothers who had lived most of their lives in Buffalo but who had been educated in Germany led every Verein except the Turnverein. Likewise, the German language newspapers passed from father to son. 84 The familial patterns and the involvement of young, German born and educated leaders, would give the Vereine long lasting consistency. Buffalo's Germans became increasingly successful in politics and in business. Holding the political balance of power between the Irish and the AngloAmericans, Germans were able to be elected to city offices. Meanwhile, many Germans became prosperous and owned most of the businesses on the east side by the 1880s. The more influential Germans joined the Buffalo club, the Chamber of Commerce and The Board of Trade, which elected a German president in 1883. The skilled German workers tended to be more conservative. For instance, they did not join in the 1877 railroad strike. However, in the late 1880 s the more recent German immigrants were leaders of a number of strikes in Buffalo. At about the same time, Germans began to use nativist arguments against the Polish. However they neither joined the the American Restrictive crusade in the 1880s, nor did they actually unite against the Poles. 85 The above would indicate that many of Buffalo's Germans were becoming Americanized.

One indication was the fact the German-Americans were 
losing the younger generations. The German language

newspapers made few attempts to interest younger readers with special columns and the Vereine and the churches showed little interest in establishing youth groups. Over one half of the students were in public schools, not in the schools of the German churches. Yox notes the increasing tendency to marry natives from different provinces, which he concludes was an assimilating factor since it ended centuries old differences among Germans. Furthermore, Yox estimates that at the turn of the century nine out of ten German-born adults could speak English making the preservation of German difficult. Thereafter, the German community became selfconscious and began to celebrate its Germanness. In 1904 the first German Day was celebrated in Buffalo and plans were made for an elaborate Schiller festival in 1905. However, according to Yox, the "self-appointed leaders of Deutschtum lacked grass-roots popularity, but they often proved more trustworthy than the elite spokesmen of (the prosperous) Germans."85 In essence, this was a strong ethnic community dissolving slowly through Americanization.

The conflict over language and education illustrates the change. The teaching of German and English in Buffalo had been an issue from the beginning. There had been struggles over the teaching of German language in 1837-39, in 18501851, and again in 1873-74. Initially the disputes dealt with the parochial schools but shifted to the public schools, were German was introduced in the elementary grades in 1866 . 
The 1873 school budget contained no funds for German instruction, causing a political uproar among Germans. At the next election the German vote helped defeat the Republican mayoral candidate, Frank Sears, by electing German, Philip Becker, and replacing four Republican Germans with four Democratic Germans on the city council. According to David Gerber, the struggle to teach German was an attempt to introduce standard German as a means to overcome dialects, especially those of northern and southern Germany. 86 The projects were probably doomed, since at the same time that language maintenance was essential to preserving German culture, Buffalo's Germans recognized that English was necessary for the economic advancement and prosperity of their children.

World War I checked the decline for a while, but also pushed it along. The outbreak of the war in Europe came two days prior to the German Day celebration. In that festive mood, the rallies attracted 30,000 participants, or about twenty-two percent of Buffalo's German population of 135,000. This made it the largest celebration ever held by the GermanAmerican community. In an ugly turn of events, German gangs terrorized the Polish sections of the city. The circulation of the German-language press rose to its highest levels--as it had in several other cities discussed. German Days continued to attract large crowds--about 20,000 in 1915 and 25,000 in 1916. Buffalo's Germans were united as never before. of course, such euphoria soon turned to despair. 
After April 1917, German clubs were dropped from the city directories, the German-American Bank changed its name to Liberty Bank. The three German-language newspapers, Die Demokrat, Freie Presse, and Arbeiter zeitung all stopped printing. Despite eliminating German in the elementary school (while retaining it in the high school), the school board and "superpatriot" mayor Buck otherwise worked hard not to irritate the German-Americans. 87 Perhaps they still recognized the importance of the German vote.

Movement out of the German east side between 1915 and 1925 compounded the effects of the war. This suburban migration negatively affected the old neighborhood. The seventy-year old stangerbund dissolved in 1922. Also, intermarriages with non-Germans began to increase in the 1920s. However, in 1920 and 1921 the Bavarian Alliance revised the summer Peoples Festival, with a heavy emphasis against prohibition. German brewer, Schwab, who would be elected mayor in 1921, was raided by Federal agents, and the Irish rallied to the cause. A German Day was organized in 1922, attended by Mayor Schwab, but it drew only 10,000 participants. This was a respectable attendance, but well below that of 1914. It is important to note that German festivities were being held so soon after the end of the war. However, the German community was much diminished. Yox concludes that the decline of the community was inevitable. 88 This is undoubtedly correct. Those Germans who became influential in business or politics, i.e. became the elite of 
the city, rapidly Americanized. The second and third generations were lost both to the German language and the German Vereine. Finally, as this generation moved to the suburbs from their small enclave, its end was sealed.

New York City, which became the main entry point for immigrants in the nineteenth century, soon became the home for immigrants of all nationalities, including Germans. In fact, it is estimated that between 1855 and 1880 only Berlin and Vienna had more German-speaking residents than New York. By 1880 there were 168,225 German-born persons living in New York City, or about fourteen-percent of the total population. That same year the German-American population was 370,095 or about thirty-one percent of the total. By 1900 there were 322,000 persons born in Germany living in New York, or about nine percent of the population; and the 761,795 GermanAmericans living in the city represented about twenty-two percent of the total. 89 over time a number of German enclaves developed in New York city. One of the earliest and most densely packed was a section of the lower east side which became known as kleindeutschland--"little Germany." The German-American community of New York deserves our consideration. Those who settled in New York tended to represent the patterns of German emigration, with some differences. Bavarians were overrepresented in New York city, i.e. their numbers in New York were as a proportion of the local German population higher than in other cities and rural areas. Hessians were over represented in early years 
but under represented by the 1880s. Both Prussians and Hannoverians made up a large portion of the Germans living in New York. In 1850 there were apparently few Saxons among New York's Germans, but by 1880 they were four percent of the German population. Based on this data, stanley Nadel concludes that the German emigrants to New York were from those locations in Germany with many artisans, shopkeepers, or skilled workers. Those urbanized areas facilitated the transition to New York. 90

Despite the overwhelming numbers of Germans in Kleindeutschland it was a fragmented community much as the case in the other cities we have studied. One form of fragmentation was by Land. For instance Bavarians tended to marry other Bavarians, or residents of the other states in southeastern Germany, which were Catholic. 91 German religious and regional splits continued in the New World. The German Jewish community of kleindeutschland may have been the largest in America; but it too was split between rcligious liberals and conservatives. The German Jews formed their own Vereine duplicating those of the other denominations or the secular Germans. 92 Furthermore, Socialists and workers formed their separate units of the various Vereine, further splitting the community.

Economic life in Kleindeutschland was varied. German workers dominated certain trades including tailors, boot and shoemakers, cabinetmakers and upholsterers, bakers, tobacconists and cigarmakers, butchers, and brewers. Former 
residents of Bremen and Hamburg succeeded in clerical jobs. Germans opened all kinds of stores to serve the needs of the residents of the district. Others started specialty manufacturing companies, of which the steinway piano company was most famous. Germans in kleindeutschland developed a small professional class, including doctors, pharmacists, opticians ministers, and teachers. Conversely, Kleindeutschland became a nurturing ground for trade unionism. Samuel Gompers, a non-German resident of Kleindeutschland, led The Cigar Makers Union and American Federation of Labor. By the 1870 s and 1880 s wealthier German families began to move out of this thriving district to uptown neighborhoods. By 1910 the area was mostly Jewish. Brooklyn and Yorkville became the new German areas. 93

The numerical strength of the New York's Germans apparently did not result in political strength. The political machine, mostly Irish, and Reformers, mostly AngloAmericans, dominated political battles late in the nineteenth century. In the twentieth century the Irish and Italians fought to control the mayor's office. By the 1920s, the Germans' greatest successes were the election of a German to the Board of Aldermen and in 1926 the election of GermanAmerican Robert Wagner to the U.S. Senate. According to Richard Bayor, in the 1920s the Germans were "not trying to protect a political empire--like the Irish, but to elect enough representation to protect themselves from an outbursts of anti-German hysteria."94 In the mayoral elections of 1937 
and 1941, Germans voted for the Democratic candidate. However, during the 1937 election Democrat Mahoney attempted to use a dispute over a parade permit for the Nazi GermanAmerican Bund against La Guardia. Germans still voted for the Democrat, but by the smallest margin of the two campaigns.95 It is possible that Mahoney's use of the Bund issue backfired, since most German-Americans wanted nothing to do with it and resented its use in the campaign.

To some observers during the 1930s, it appeared as if European politics were being transferred to New York. The Italian language newspaper was pro-Fascist. The Nazi German American Bund was strident and published its own newspaper. New York's Jews organized a boycott of German goods provoking the Bund into a boycott of Jewish stores. 96 In the 1930s, Yorkville on the east side, was the new "little Germany" of the city. Many of the German immigrants who arrived during the 1920s lived there and Yorkville soon became the center of activity for the Bund in New York. 97 . The Ridder Brothers, owners of the New Yorker staats-Zeitung, although personally involved in blocking the Bund's bid to control the German clubs and to gain influence in their paper, did not criticize Nazi Germany in the paper. 98 During the 1930 s the GermanAmerican leadership of New York, while not favoring the Nazis, were also reluctant to publicly criticize the government of Germany. At the outbreak of war in Europe the staats-zeitung called for American neutrality. At the same time it avoided praising Hitler but understood the basis of German foreign 
and military policy.99 Despite the loud displays of the Bund in New York, and the ambivalent feelings of the GermanAmerican leadership toward them, the majority of GermanAmericans were more concerned with proving their loyalty and making a living to be involved in such activities. According to Bayor once the war started there was a "greater reluctance to be associated with anything German."100 The GermanAmericans were on their way to becoming the vanished group that Glazer and Moynihan could not find in New York, or the disinterested individual that wilk found in Yorkville.101 During the nineteenth century, German enclaves existed in a number of American cities. Each of the enclaves was a miniature city with shops, theaters, and club halls all catering to a German-speaking population. The pervasive character of Germanness plus the efforts of the community leaders to maintain Deutschtum appeared to present a monolithic picture to outsiders. Yet the communities were split on religious, provincial, political, and class lines. Despite the protective nature of the enclave, the very nature of living and working in a city led to a breakdown in ethnicity. One had to work and do business with non-Germans, which required the use of English starting the assimilation process. The majority of the children attended public schools furthering assimilation. Hysterical anti-German attacks during World War I did not entirely destroy Deutschtum, as is often thought, but it undoubtedly hastened its end, in most cities. Over the course of years, residents 
moved away from the enclaves. Some returned on occasion to partake of the culture, but this gave false illusions of continued Deutschtum. The outmigration finally ended the German neighborhoods. These events occurred at different times in different cities, depending to a great extent on the date of arrival and number of newly arriving immigrants. The discussion of the major American cities with their large German-American enclaves, is relevant for the the study of Manchester and Lawrence and their German-American communities. As will be shown, the much smaller German population of Manchester and Lawrence developed a Vereinsleben as extensive as that of the larger cities discussed. It will be shown that they maintained Deutschtum and a stronger version of it longer than the other cities, because many of the immigrants came from the same regions of southeastern Germany, especially Saxony. But Deutschtum, was also lost to Americanization and the end of the enclaves through out migration. Manchester and Lawrence did not grow naturally as cities but grew from nothing into textile production centers. As a result employment opportunities in vast textile mills in the cities attracted immigrants, and, in particular, textile workers from southeastern Germany. In order to understand more fully the German-Americans in the two textile cities, the history and development of Manchester and Lawrence must be presented. 
${ }^{1}$ Herbert $J$ Gans. The Urban Villagers: Group and Class in the Iife of Italian Americans, (New York, The Free Press, 1982). Oscar Handlin, Uprooted, (Boston, Little Brown, 1951) Ward, cities and Immigrants: $A$ Geography of Change in Nineteenth-century America, (New York, Oxford University Press, 1971). Stanley Liebrson, Ethnic Patterns in American cities, (New York, The Free Press of Glencoe, 1963). Kenneth T. Jackson, crabgrass Frontier: The Surburbanization of the United States, (New York, Oxford University Press, 1985).

${ }^{2}$ Conzen "Immigrant Neighborhoods, and Ethnic Identity: Historical Issues," Journal of American History, 66 (December 1979): 603-615. James Berquist, "German Communities in American Cities: An Intrepretation of the Nineteeth-Century Experience," Journal of American Ethnic History, 4 (Fall 1984): $9-30$.

${ }^{3}$ Conzen. "Immigrant Neighborhoods," 608-09.

${ }^{4}$ Berquist, "German Communities in American Cities," 9.

${ }^{5}$ Hermann Hagedorn, The Hypehnated Family: An American Saga, (New York, Macmilian, 1960), pp. 43, 81, 88 .

${ }^{6}$ Glazer and Moynihan, Beyond the Melting Pot, p. 311.

7 Berquist, "German Communities in American Cities," 10.

${ }^{8}$ Kathleen Neils Conzen, Immigrant Milwaukee, 1836-1860: Accomodationa and Community in a Frontier City. (Cambridge, Harvard University Press, 1976), pp. 11-13. chart on page 14, and pp. 15-20. Faust, German Element, Vol I, p. 508 .

${ }^{9}$ conzen, Immigrant Milwaukee, p. 34 .

${ }^{10}$ Ibid., pp. $34-35,35161,36$.

${ }^{11}$ Ibid. , p. 127 .

12 Ibid., p. 145.

13Ibid., pp. 127, 135, 148-49, 151-52.

${ }^{14}$ per Verein means club or association and is often 
combined with the type of the club as in Turnverein, gymnastics club or sangerverein, singing society, etc. The plural is Vereine. When combined as a prefix it is Vereins as in Vereinslokal, club meeting room; Vereinskamarad, fellow club member; or Vereinswesen, club character; or Vereinsleben, club life. These are commonly used terms in the German language newspaper of Lawrence, MA the Anzeiger und Post.

${ }^{15}$ Conzen, Immigrant Milwaukee, pp. 154-55.

${ }^{16}$ Ibid., p. 155.

17 Ibid. , pp. 161-163, 165-167.

${ }^{18}$ Ibid., pp. 168-69, 177, 180.

${ }^{19}$ Ibid. , pp. 180-81 182-83, 184 .

${ }^{20}$ Gerd Korman, Industrialization, Immigrants, and Americanizers: The view From Milwaukee, 1866-1921, (Madison, The State Historical Society of Wisconsin, 1967), p. 43.

$2 I_{\text {Ibid., p } 43 .}$

22 Ibid., p. 52 .

${ }^{23}$ Ibid., pp 165, 168, 169, 170, 171. William Tell, written by Italian Rossini and celebrating the Swiss struggle for independence from Austria, is an odd choice for a protest.

${ }^{24}$ Hartmut Keil, John B. Jentz, German workers in Chicgo: A Documentary History of Working class Culture From 1850 to World War I, (Urbana, University of Illinois Press, 1988) pp. 4-5. See also Hartmut Keil "Chicago's German Working Class, in 1900" in German Workers in Industrial Chicago, 1850-1910: A Comparative Perspective, eds. Hartmut Keil and John $B$. Jentz eds, (Urbana, Northern Iliinois University press), 1983, p. 21, Table 1.

$25_{\mathrm{Keil}}$ and Jentz, German Workers Documents, pp. 4-5. Hartmut Keil "Immigrant Neighborhoods and American Society: German Immigrants on Chicago's Northwest side in the Late Nineteenth Century," in German Workers' Culture in the United States, 1850-1920, ed. Hartmut Keil, (Washington, Smithsonian Institution Press, 1988), 29-33.

${ }^{26}$ Keil and Jentz, German Workers, Documents, pp. 5-7. Hartmut Keil "Chicago's German-Working class in 1900" in Industrial Chicago 1850-1910 Comparative Perspective, ed. Keil and Jentz p. 23, Table 2. Hartmut Keil "Immigrant Neighborhoods and American Society: German Immigrants on 
Chicago's Northwest side in the Late Nineteenth Century," in, German Workers'Culture, ed. Hartmut Keil, 29, 37, 38 .

${ }^{27} \mathrm{Keil}$ and Jentz, German Workers, Documents, p. 6. Hartmut Keil "Immigrant Neighborhoods and American Society: German Immigrants on Chicago's Northwest Side in the Late Nineteenth Century," in Hartmut Keil ed, German Workers' Culture 1850-1920, 41-44.

${ }^{28}$ Hartmut Keil "Immigrant Neighborhoods and American Society: German Immigrants on Chicago's Northwest Side in the Late Nineteenth Century," in German Workers' culture 1850-1920, ed. Hartmut Keil, 48-49. Leslie B. Tischauser, The Burden of Ethnicity: The German Question in Chicago, 1914-1941, (New York, Garland Publishing, 1990), p. 1 .

${ }^{29}$ Hartmut Keil "Immigrant Neighborhoods and American Society: German Immigrants on Chicagos's Nortwest Side" in German Workers Culture, 1850-1920, ed. Hartmut Keil, 45. Klaus Ensslen, "German-American Working class saloons in Chicago: Their Social Function in an Ethnic and classSpecific cultural Context," in German Workers culture, 1850-1920, ed. Hartmut Keil, 157-180. The term Kneipendeutschen is used in Kathleen Neils Conzen, "The Paradox of German-American Assimilation, Yearbook of GermanAmerican Studies, 16 (1981): 159.

30 Tischauser, Burden of Ethnicity pp. 1, 2. The figures given are 76,000 Catholics and 40,000 Lutherans. The balance is not accounted for.

${ }^{31}$ Ibid., pp. 14-15.

32 Ibid., pp. $30-32,35-6,38-41,42-43$.

33 Melvin G. Holli, "Teuton vs slav: The Great War sinks Chicago's German Kultur," Ethnicity, 8, (December, 1981): 410-412.

${ }^{34}$ Ibid. , 422.

${ }^{35}$ Ibid. , 413 .

${ }^{36}$ Ibid., 406-451.

37 Tischauser, Burden of Ethnicity, pp. 59. 64, 68-70, 74 .

${ }^{38}$ Ibid., pp. 118-119 132, 140-48, 149.

${ }^{39}$ Ibid., pp. $83-84,87,88$. 


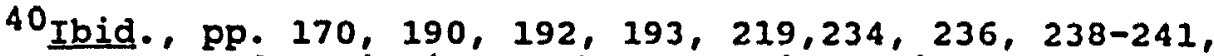
243,244 . For a description of how the Missouri synod of the Luthern church favored Hitler see Kenneth $C$. Barnes, "The Missouri Synod and Hitler's Germany," Yearbook of German American Studies, 24 (1989): 131-148.

41 Tischauser, Burden of Ethnicity, pp. 259-264. A similar conclusion is reached by Holli in "Teuton vs slav," 447.

42 Don Heinrich Tolzmann, The Cincinnati Germans After the Great War, (New York, Peter Lang, 1987), pp. 1-6, 7 . Tolzman gives the birth places, as Prussia, 30.3\%; Bavaria, 19.7\%; Hannover, 17.5\%; Baden 10.4\%; Württemberg, 6.3\%; Oldenberg, 4.78, Hessen, 4.7\%; Saxony 1.9\%; Austria, 1.1\%; and other unidentified states, $3 \%$.

\section{Ibid., p. 7.}

${ }^{44}$ Guido A. Dobbert, The Disintegration of an American Ethnic Community: The cincinnati Germans, 1870-1920, (New York, Arno Press, 1980), pp. 7, 13, 10, This is one of the few references to German Presbyterian churches, which were among the most important German denominations in Manchester and Lawrence.

$45_{\text {Ibid. , pp. 7, } 10 .}$

46 The opinions about the duration of clubs and the importance of the Turnverien are from Dobbert, Disintegration, pp. 22,28 . The Turnverein was often the most important club in many cities but Tolzmann, cincinnati Germans, notes that there were three in Cincinnati, p. 12; The number of clubs is from Tolzman, cincinnati Germans, $p$. 12. Both agree on the pionier Verein, Dobbert, Disintegration pp. 35-36, Tolzman, Cincinnati Germans, p. 13 . Don Heinrich Tolzmann, in his PhD Dissertation, "The Survival of an Ethnic Community: Cincinnati Germans, 1918 through 1932", University of Cincinnati, 1983 discusses the ethnicity and assimilation theories of various authors. Dobbert and Conzen he classifies as from "The Dissapperance School;" Audry olson, PhD Dissertation, "St. Louis Germans," and Richard O'Connor he classifies as the "Assimilation School;" he describes himself and Frederick Luebke as members of the "Ethnic Survival School," pp. 6-27.

$$
\begin{aligned}
& 47 \text { Tolzmann, Cincinnati Germans, p. } 13 . \\
& { }^{48} \text { Dobbert, Disintegration, p. } 59 . \\
& { }^{49} \text { Ibid. , pp. 59-63. }
\end{aligned}
$$


50Ibid., pp. 102-103, 118, 104-147 passim.

51 Ibid., pp 102-147

52 Ibid., pp. 173-217 passim, 233, 256, 280, 297, 303, $307,313,257$. Of the 79.4 who were middle class twothirds were being skilled craftsmen or foremen and the remaining third were in lower-level white-collar jobs such as shopkeepers, clerical workers and salespeople. The laboring class made up about sixteen percent of the club officers.

${ }^{53}$ Tolzmann, Cincinnati Germans, pp. 15 128, 129, 130, 186-202. Dobbert, Disintegration, 352, 407-415, 416-417, 429 .

${ }^{54}$ Tolzmann, cincinnati Germans, pp. 144-51.

55 Ibid., pp. $34,3944,46,47,37,19$.

${ }^{56}$ Ibid., pp. 19-20.

57 Ibid., p. 38 .

58 Ibid. , p. 75 .

${ }^{59}$ Ibid., Catholic Vereine, pp. 79-82. Jews in Veriene, pp. 75,83 .

${ }^{60}$ Tolzmann, cincinnati Germans, pp. 23, 24, 28. Additionally, Maude Gamble's mother was Fanny Nast the daughter of the founder of the German Methodist Church, Wilhelm Nast. These connections helped Nippert to become an influential leader of the German-American Community. pp. 2526. Also Dobbert, Disintegration, pp. 301-315, and passim.

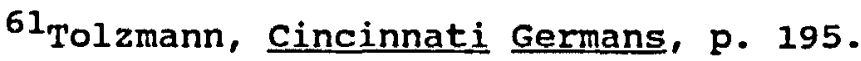

62 Ibid., pp. 195-98.

63 Ibid. , pp. 20-21.

${ }^{64}$ For a discussion of the actions of the Germans, especially the Turners at the beginning of the Civil War, see Faust, German Element, Vol I. pp. 528-542 and Henry Metzner, History of the American Turners, (Rochester, NY: National Council of The American Turners, 1974), pp. 18-19.

${ }^{65}$ For population figures see Faust, German Element, Vol I, p. 580: Audry L. Olson, st. Louis Germans, 1850-1920: Nature of an Immigrant Community and its Relation to the Assimilation Process, (New York, Arno Press, 1980) p. 47; and David $w$. Detjen, Germans in Missouri, 1900-1918: 
Prohibition, Neutrality, and Assimilation, (Columbia, Mo.,University of Missouri Press, 1985), p. 4.

${ }^{66}$ See 0lson, st. Louis Germans, for early settlement 1-7. Both olson, st Louis Germans, p. 19; and Detjen, Germans in Missouri, p. 6, indicate that there was no single German enclave in St. Louis.

6701son, st Louis Germans, pp.90, 96-99, 107-108.

68 olson, St. Louis Germans, pp. 89, 90, 96-99, 111-113, $117,135-145$. Olson divides the clubs into four main groups, not counting the Church Vereine. There were the Unterstützngsvereine, or benevolant aid societies, the largest group; the Iandsmanschaften representing every Province; the Gesanguereine, or singing societies representing the second most numerous kind; and the Turnverein. Detjen, Germans in Missouri, notes the same four types of vereine, p. 15. He also cites in 1910, that there were 186,404 persons born in Germany or had one parent born in Germany. Faust, German Element, Vol $I, p .580$ gives the total of German parentage in 1900 as 199,182 . The middle class makeup of the Vereine is discussed in olson, st. Louis Germans, pp. 255, 265, 267-268.

69 olson, st. Louis Germans, pp. 152, 176.

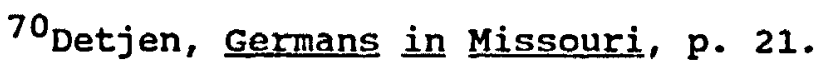

71 olson, st. Louis Germans, p. 168.

72 Ibid., p. $185-86$.

73 Ibid., p. 210-211.

74 Ibid., p. 212.

${ }^{75}$ Detjen, Germans in Missouri, p. 27.

76 olson, st. Louis Germans, pp. 212-216, 233-34, 243, 246. Detjen, Germans in Missouri, p. 27.

77 olson, st. Louis Germans, pp. 281-282. Detjen, Germans in Missouri, pp. 176-187.

78 Andrew P. Yox, "Decline of the German-American Community in Buffalo 1855-1925," PhD Dissertation, University of Chicago, 1983, 24, 9, 16, 8. Lawrence A. Glasco, Ethnicity and Social structure, Irish, Germans and Native Born of Buffalo, New York, (New York, Arno Press, 1980), p. 18. He also gives a figure of about oñe-haif German, and further breaks down the Germans as Bavarians 20\%: Hesse, Baden, Württemberg, $16 \%$ or $36 \%$ from the south; $15 \%$ 
were from the north--9\% from Prussia and $6 \%$ from Hannover, Mecklenberg, and Saxony.

79 yox, "Decline in Buffalo," 54.

${ }^{80}$ Ibid., 76, 72, 73n.

${ }^{81}$ yox, "Decline in Buffalo," 24, Glasco, Ethnicity of Buffalo, p. 18.

${ }^{82}$ Yox, "Decline in Buffalo," 116.

${ }^{83}$ Ibid., 228, 127, 131-132.

${ }^{84}$ Ibid. 49-50, 53 from the Freie Presse, of 3 October $1904,179,117,81,181$.

${ }^{85}$ Ibjd., 197, 199, 200-201, 228, $245255,268$.

86, David A. Gerber, "Language Maintenance, Ethnic Group Formation and Public Schools: Changing Patterns of German Concern, Buffalo, 1837-1874," Journal of American Ethnic History, (Fall, 1984) 31, 46-49, 53. Yox, "Decline in Buffalo," 144 .

${ }^{87}$ Yox, "Decline in Buffalo," 289, 291, 293, 295, 302, 319. The outmovement rate was the highest of any decade since 1855, 224.

${ }^{88}$ Ibid. , 338, 349, 350, 360 .

${ }^{89}$ stanley Nadel, Little Germany: Ethnicity, Religion, and Class in New York City, 1845-1880, (Urbana, University of Illinois Press, 1990), Nadel focuses on the lower east side, but includes other German neighborhoods of the New York City area. pp. 1. 29, 32. For population figures see p. 42. See also, Faust, German Element, Vol I, p. 508.

90 Nadel, Little Germany, pp. 23, 24, 26, also figure 2-A which gives the province from which they emigrated, and figures 3,4 and 5 show age distribution. Nadel does not clearly demonstrate his conclusion about the artisan, shopkeeping or urban origin of the emigrants.

${ }^{91}$ Ibid., 49-51. In 1860, $72 \%$ of married Bavarians were married to other Bavarians, but in 1880 , $55 \%$ of Bavarians were married to Bavarians, but the total was $80 \%$ when it included neigboring states of Baden, Württemberg.

92 Ibid., pp. 99-103.

93 Ibid. , pp. 104-121. 
${ }^{94}$ Richard $н$. Bayor, Neighbors in conflict: The Irish, Germans, Jews, and Italians of New York City, 1929-1941, (Baltimore, The Johns Hopkins University Press, 1978), pp. 53-55. 59-78, 114-118.

GERMAN VOTES

95 Ibid., pp. 130-143.

$\begin{array}{lll}\text { REPUBLICAN (LaGuardia) } & 1937 & 1941 \\ \text { DEMOCRAT (Mahoney) } & 46.4 & 23.9 \\ \text { (O'Dwyer) } & 53.5 & 75.6\end{array}$

96 Bayor, Neighbors in Conflct. pp. 57-76, 114-118. wilk, "Yorkville, Twenty Years After," 41-48. See also Sander Diamond, the Nazi Movement in the Unites States, (Ithica, Cornell University Press, 1974), passim. Some issues connected with the American Nazis will also be discussed in Chapter VII.

97Bayor, Neighbors in Conflict, pp. 64-67.

98 Bayor, Neighbors in Conflict, pp. 65-66. Discussions of the Ridder Brothers and the New Yorker Staats-Zeitung can be found in Stephan Economides, Der Nationalsozialismus und die deutschsprachige Press in New York, 1933-41, (Frankfurt, Peter Lang, 1982), and "The Foreign Language Press, Fortune, 22 (November, 1940), 90-93, 102, 104.

99 Bayor, Neighbors in Conflict, p. 115.

${ }^{100}$ Ibid. , pp. $123,125$.

${ }^{101}$ Glazer and Moynihan, Beyond the Melting Pot, pp. 111112. Wilk, "Yorkville Twenty Years After," 41-48. 
CHAPTER III

TEXTILE CITIES:

MANCHESTER, NEW HAMPSHIRE AND LAWRENCE, MASSACHUSETTS

Originating in the lakes and mountains of New Hampshire and entering the sea at Newburyport, the Merrimack River became the power source for the largest concentration of textile manufacturing in the United states during the nineteenth century. The value of the river was recognized in 1821 when a group of Boston investors created the textile city of Lowell. In this model city New England farm girls, who supplied the labor, lived in company-provided boarding houses under strict supervision. As the mills expanded Irish immigrant workers were employed to build dams, canals, and mill buildings. Some, tired of moving from construction site to construction site, stayed and soon replaced the New England farm girls as employees in the mills. The example of Lowell soon led to the establishment of other industrial cities along the Merrimack, including Nashua and Manchester in New Hampshire and Lawrence and Haverhill in Massachusetts. Even in Newburyport, originally an eighteenth century seaport, a number of small leather and textile mills were built. 1 Manchester and Lawrence, about fifty-five miles apart as the river flows (and about twenty-five by railroad) developed into textile production centers. For a time they were the largest in the United states, if not in the world. 
In 1810 the sleepy colonial village of Derryfield, population 113, was renamed Manchester in honor of the English industrial city. That same year a group of investors organized the Amoskeag cotton and Wool Manufactury, later changed to Amoskeag Manufacturing Company (1825). Little was actually accomplished until about 1838 , when the building of effective dams made water-powered mills possible, and the construction of mills and tenement housing soon followed. Initially, the Amoskeag Company built mills to lease to the stark Manufacturing Company, but in 1840 it began the construction of its own mills. The paternalistic nature of the company was evident from the start by the company owned Amoskeag Bank (1842-1846) where the employees could deposit their wages. 2

The Amoskeag Manufacturing Company continued to grow and diversify. The company built a foundry and a machine shop and began to produce locomotives and fire engines for which it became famous. During the Civil war the shop supplied muskets to the Union Army. Soon, the machine shop turned to the production of looms and other textile machinery for the Amoskeag Company. Meanwhile, the textile mills and dye houses continued to grow, and by 1853 there were nine separate mills. By 1855 the Amoskeag operated 82,846 spindles and 2,145 looms using over nine million pounds of cotton and employing 3,200 workers. By 1875 the nine mills contained 125,000 spindles and 3,500 looms, used 225,000 pounds of cotton a week, but employed only 2,000 workers. 3 
Although in the 1880s, the company still relied on the power of the Merrimack River, conversion to steam power had started.

The sheer size of the Amoskeag was astounding. In 1912 there were 15,500 employees, with an annual pay roll of almost eight million dollars. Those employees worked at 670,000 spindles and 24,400 looms. The mill area covered $5,844,340$ square feet (or 137 acres), and produced $258,930,360$ yards of woven cloth per year, consuming $54,600,000$ pounds of cotton and wool, 131,484 tons of coal, and 75,000 gallons of oil per year. In 1912 , the number of spindles at the Amoskeag was equal to 2.38 of the total spindles in the United States, and $6.39 \%$ of the spindles in Germany. At its height, around 1916, it was the world's largest textile mill, employing up to 17,000 workers in approximately thirty mills. It had seventy-four cloth making departments, three dye houses, twenty-four mechanical and electrical departments, three major steam power plants and one hydroelectric power plant. There were print shops and other related enterprises. A company report in 1920 gave the size as $7,302,734$ square feet of floor space, or 167 acres. That year the company produced 51 miles of woven cloth per hour. 4

The growth of Amoskeag paralleled the growth of Manchester and the Amoskeag Company controlled the city's development. In fact, the mills built the city. The Amoskeag Company, for example laid out the plans for the 
city. Feeling that church attendance was good for workers, the Amoskeag deeded lots to at least twelve different churches between 1839 and 1880. Additionally it deeded land for schools, fire stations, city hall, a court house, bridge access, a library, the city commons, and playgrounds. In 1912, the Company offered to sell house lots to employees with over five years service, at favorable mortgage terms if the employee built a house, lived in it and remained employed. The Amoskeag owned most of the available industrial land, so it could control the type of industry established in Manchester. Unlike some other company towns, the Amoskeag did not control all aspects of life in the town. For instance, there was no single company store, only about fifteen percent of the workers lived in company housing, and there were private shops, places of entertainment, and other factories including a shoe and a cigar factory. 5 Despite these differences from other mill towns, the Amoskeag Company clearly dominated Manchester. In the words of Tamara Hareven and Ralph Lagenbach, "there was hardly a person in Manchester between 1838, when construction began, and 1936, when the mills shut down, whose life was not in some way affected by the company." 6

The Amoskeag influenced its workers and the city in a unique way through the Amoskeag Textile club. Founded in 1910, its purposes included the advancement of managers and better understanding between employers and employees. Established on an outing to Hamption Beach, New Hampshire, 
ostensibly an employee organization, company control was evident when the elected officers were top managers including Superintendent william Parker straw. Numbering over 400 members in 1912, the club was incorporated in Manchester. Its "Amoskeag Bulletin," published from 1912 to 1922, contained company and employee news. The company donated a park which became known as "Textile Field." Over thirty thousand dollars were expended into making this one of the best baseball fields in the area with grandstands and club houses. At the dedication, the Boston Red Sox played the local all-stars. The club took over operation of the Amoskeag Company Store, which was an outlet of the company's products at reduced prices. ${ }^{7}$ The club also formed the Textile School, among whose purpose was to train the "employees [who are] aliens from strange lands... in the practical efforts of manufacturing life.... [To assist] the ambitious ones to rise to the heights...[०f] usefulness and efficiency." 8 It is clear that the purpose of the club was to influence its employees and, either directly or indirectly, life in the city.

There had to be a source of workers for the massive Amoskeag. By and large, immigrants provided the labor. In 1860 the 5,480 foreign-born constituted twenty-seven percent of Manchester's population of 20,109; and of the foreign born, 3,976 were Irish, a number of whom worked in the mills. Over the next several decades, Manchester attracted Swedish, Belgian, Scotch, and German migrants to 
the more skilled positions in the mills. In the 1870 s French-Canadian immigration increased. A combination of worsening economic conditions in Quebec, a rail link from Montreal to Boston (through Manchester and Lawrence), and active recruitment by the Amoskeag and other companies led to this immigration. The mill companies believed that the French-Canadians were both hard workers and not troublemakers. They actively sought French Canadians and aggressively advertised in Quebec Newspapers. By 1910, French Canadians comprised thirty-five percent of the Amoskeag's labor force and thirty-eight percent of the city's population. Early in the twentieth century small numbers of Greeks and Poles began to arrive in Manchester and worked in the Amoskeag. 9

Absentee ownership and control characterized the Amoskeag Company. Boston financiers owned and controlled the company, which was managed in Manchester by a local agent. The straw family held this position for three generations. Ezekiel straw, who became Governor of New Hampshire, was followed by his son Herman straw and his grandson William Parker straw. 10

The fortunes of the company declined after world War I. The Company found that its size was now a detriment. Not only was there too much capacity in the textile industry, but the mills in Manchester were just too big. Attempting to cut costs, the company demanded wage cuts or increased the productivity of the machinery, requiring the employees to 
work faster. An announcement of an increase in working hours and a wage cut in 1922 led to the first long-term strike in the company's history. After the strike, which the Company won, it imposed its own union on the employees. However, relations between the company and the employees were no longer quite the same. In 1933, another labor dispute occurred and the workers dropped the company union for the United Textile Workers Union. Intermittent strikes dragged through 1934 into 1935, when the Company finally shut down. 11 The economic life of Manchester took decades to recover. Meanwhile, Lawrence took shape on waterfalls twelve miles down the Merrimack from Lowell. Their power potential was recognized by a group of investors, who set out to create a planned textile city to rival Lowell. In 1845 , the investors led by Abbott Lawrence formed the Essex Company and began construction of the largest dam on the Merrimack. In 1847 the state of Massachusetts chartered Lawrence, a town totaling about six square miles on both sides of the river, by taking land from Andover and Methuen. This resulted in what later became one of the smallest, most densely packed, and most immigrant cities in the United States. In 1910 over ninety percent of its population was first- or secondgeneration Americans. 12

The Essex Company, a real estate holding and construction company, astutely purchased the water power rights to the river. In addition to the dam, bridge and canal, the Essex also built tenement houses, a foundry, a 
machine shop, and several other buildings. The Essex also constructed mill buildings for the independently chartered Atlantic Cotton Mills, the Pacific Mills Company, the Pemberton and the Duck mills. Abbott Lawrence and the other principals of the Essex company were the major stock holders in those companies. 13 Through this arrangement the Essex earned profits in two ways. First, from the construction of the mill buildings, and, second, from the profits of the companies producing cloth in them.

Additionally, the company owned the Essex Machine Shop produced tools, textile machines, and locomotives, much as its counterpart in Nanchester. Hard hit by the Depression of 1857 the shop closed for two years before being sold to the Everett Company. Around 1917, the Everett was operating 4,680 looms. The Depression also idled the Bay state Mills, which reformed as the Washington Mills in 1858 for the production of worsted wool goods. The Atlantic Cotton Mills was incorporated in 1846 with Abbott Lawrence and Charles Storrow, the engineer of the Lawrence Dam, as principals. By the 1880s it employed about 1,100 workers at over 100,000 spindles and 1,921 looms producing about 500,000 yards of cotton per week. The Pacific Corporation established in 1853 for printing and dyeing cotton and worsted wool. By the 1880 s it had 150,000 combined spindles and 4,600 looms, and also 25 printing machines in 23 buildings covering 44 acres and powered by water and steam. About 1917, it employed 7,700 at 3,833 cotton looms and 3,435 wool looms, and wove 
330 miles of cloth each day. Also formed in the 1850 s was the Lawrence Duck Company, a manufacturer of cotton duck and sail twine. The Everett Mills a producer of ginghams had 33,280 spindles, 1,014 looms and over 1,000 employees in the 1880s. The Arlington Woolen Mills incorporated in 1867 eventually built up to twenty mill buildings along the Spicket River, a small tributary, running from Lawrence through Methuen to Salem, New Hampshire, a distance of about three miles. Around 1917, it employed 6,500 at 117,000 spindles and 2,000 looms. It used 1,000,000 pounds of wool a week to produce 450,000 yards of worsted cloth. By the early twentieth century, The Monomac Spinning company and the Katama Mill typified the smaller worsted companies in Lawrence. At the time of world war I, the former had 350 employees and the latter 300. Lawrence was considered the greatest worsted center in the world. That reputation and an absence of unionism was one of the reasons for the consolidation of seven smaller mills and the Washington Mills in 1899 into the American Woolen Company. In 1905, the American constructed the massive Wood Mills, one of the world's largest woolen mills. It was one-third of a mile long, covered over 30 acres, and contained over 250,000 spindles. It and the company's adjacent Ayer Mill, built in 1910, employed over 16,000 workers. 14 Up until the time of the founding of the American Woolen Company, no one company was so dominant. Although it is true, through the interlocking ownerships the owners of the antecedent 
companies controlled the economic development of the city.

The textile mills in Lawrence also required large numbers of employees. Ardis Cameron states that by 1910 "three-quarters of Lawrence's population was directly dependent on the mills," with well over half "being women and children."15 From her figures it is possible to estimate 38,000 working in the mills. Most of the workers were immigrants, but unlike Manchester, Lawrence attracted both larger numbers and a wider variety of ethnic groups. In 1872, according to Donald Cole, 3,800 of the 4,700 employees at the Pacific and Atlantic Mills were foreign born. And by 1878, only 3,000 natives were employed out of 9,000 workers: and among the foreign-born Irish and English predominated. By this time, the number of skilled workers from Germany, particularly from Saxony, silesia, and Bavaria increased. Like Manchester, French-Canadians emigrated to work in the mills and, by 1900 made up twenty percent of the immigrants in Lawrence. In the 1890 s immigrants from eastern and southern Europe followed. By 1910, 41,319 (or 48.1\%) of the 85,892 persons living in Lawrerce were foreign born. Among the foreign born in descending order of country of birth were: (French) Canada (9498), Italy (6693), Ireland (5943), England (5659), Russia (4366), Germany, (2301), Turkey (2077), Scotland (1336), and France (788). In 1905 Lawrence ranked first in Massachusetts in foreign-born as a percentage of population. 16

The defining event in Lawrence's history was the strike 108 
of 1912, commonly known as the "bread and roses strike." A Massachusetts law, effective in January 1912, reduced the work week from 56 to 54 hours. The mills complied by lowering the hours and the wages proportionally, which meant a weekly reduction of 32 cents. On the first payday in January the workers, led by the women, who said they wanted both bread and roses, walked out of the mills. The women, the initiators of the strike, continued as its main supporters. For the first time, the strike united the different ethnic workers in a common cause. A number of organizers and agitators arrived in Lawrence to assist the strikers. The Industrial Workers of the World sent its colorful and powerful speaker Big Bill Haywood and its strike organizer, Joseph Ettor. Elizabeth Curly Flynn, a well known agitator, and the Socialist poet Arturo Ginovannitti also arrived. A cache of dynamite, later found to have been planted on orders of William Wood, owner of the American Woolen Company, led to the arrest of Ettor and Ginovannitti. Shortly thereafter, a young woman striker and a boy were killed by the militia and police. In what might be called a stroke of genius, it was decided to send the children of the strikers to other cities to be housed and fed. Their arrival in several cities prompted parades by the Socialists. Concerned about the bad publicity, it was decided to stop the departures. Baton-wielding police attempted to block the departure of some children at the train station, and caused a riot. Several women and children 
were injured and a number were arrested, creating even more negative publicity. This prompted a congressional investigation, at which the mothers and children testified, and which the wife of President Taft attended. Meanwhile, the mills had been completely shut down for six weeks. The American Woolen Company negotiated a settlement and the workers returned to the mills two weeks later with substantial wage increases. 17 As a result of the victory of the Lawrence workers, textile workers throughout New England also received wage increases.

Female, male, and child laborers, and immigrant workers remained united, insuring victory. Despite the well publicized I.W.W. presence in Lawrence, a local committee of ten workers was actually in control. The Italians, although deprived of their leaders through arrest, were the backbone of the strike. A tactic of the owners was to pit one ethnic group against another, but when the Italians were unwilling to break the strike it improved the position of the strikers. The Franco-Belgians, Poles, and syrians played important roles in the strike. Germans, except for the socialists, were slow to join the strike, but a majority eventually did. This must have hurt the mills, since many occupied skilled positions. The Irish, now in positions of political power in the city, and some established economically, did not side with the strikers. The women were crucial to the success of the strike, since they planned and organized marches, spread information, controlled 
neighborhoods, attacked "scabs," and provided assistance to children and families. 18

One effect of the strike was to revive anti-nativist sentiments among the leaders of Lawrence. Activities to Americanize the immigrants intensified, starting early as 1912, and Lawrence became famous for its Americanization programs. After World War I, textile production declined. Labor reacted to company demands for wage cuts or increased production by striking in 1919. This helped revive beliefs that certain "immigrants were "un-American," and the strike "gave those who refused to join a chance to show their own loyalty by condemning the strike leaders as Communist."19 cole concludes that as the 1920 s began, Lawrence was "no melting pot," but at the same time the immigrants had become Americans. 20

Between the World Wars, Lawrence's textile companies faced the same problems as the Amoskeag; excess capacity, aging equipment, and high wages. In 1922, striking Amoskeag workers pointed out that northern textile operatives could be making as much as $\$ 4.72$ per week more than their southern counterparts. 21 Rather than reinvest in the old buildings in the North, textile companies began building new plants in the South to take advantage of lower wages and proximity to the cotton fields. 22 They also made poor production decisions such as continuing to "produce blue serge for two years after the market collapsed in 1923, because 'there'11 always be a demand for blue serge."'23 That was the same year that 
gigantic American Woolen made its "last significant profit."24 American Woolen was particularly poor in business judgment. William wood built a modern facility and experimental community for managers at Shawsheen village outside Lawrence. Not only did the company not operate the Shawsheen mills, neither did it build plants in the south. 25 Lawrence, like Manchester, was basically a one-industry town. Unlike Manchester where one massive company dominated the city, and whose closure caused the whole city to collapse, Lawrence's death was more gradual. The mills were running well below capacity and a number had ceased production. Available space, an experienced labor force, and knowledge brought from Germany even gave the opportunity in 1937, for a German Jewish refugee to start a specialized knitting mill in space rented from the Everett Mills. 26 Perhaps this gave one small glimmer of hope of retaining the textile industry and its jobs.

World War II military needs and post-war civilian demand extended the life of those textile mills still in existence. Despite the profits from government contracts, the mills did not modernize nor prepare for new civilian markets. Once the war ended, the mills never operated at anything near fullemployment or capacity. The very nature of the early arrangements of the mills, especially the control of land and water rights, led to stagnation. Control of water rights meant control of hydro-electric capacity and rates. Mill owners wanted to control the local labor and wage rates, and 
often opposed new industries. 27 Their attitude might be typified by the remark of the company official that "American doesn't owe Lawrence a God-damned thing."28 In the end, Lawrence continued to slide into decay--a decay that continues to the present.

One wag in Lowell described his city in 1974, as "the only cemetery with electric lights."29 such a statement could have described both Manchester and Lawrence in 1974, when both cities were in a state of advanced decline and depression. Manchester experienced somewhat of a revival in the 1980s when high-tech and financial companies located there to take advantage of New Hampshire's lack of taxes. However, in 1993 there are still many vacant locations on Elm street (the main street) and in the massive mills. Lowell revived partially as a result of large doses of federal aid arranged by Senator Tsongas, a native; and the location of some high-tech industries in the city. Lawrence, mainly bypassed by the industries, received no federal funds, and remains the most depressed. A curious anomaly of immigration patterns continues in the cities on the Merrimack. In the nineteenth century Germans settled in Lawrence and Manchester and not in Lowell. In the twentieth century, Hispanics settled in Lawrence and South-east Asians in Lowell. In Manchester no single immigrant group dominates, as the Hispanics do in Lawrence and the South-east Asians in Lowell; but it has attracted small numbers of both groups. 
CHAPTER NOTES

\author{
CHAPTER III
}

1Thomas Dublin, Women at Work: Transformation of Work and Community in Lowell, Massachusetts, 1826-1860, (New York, Columbia University Press, 1979), pp. 2-32, 82. Brian C Mitchell, The Paddy Camps: The Irish of Lowell, 1821-1851, (Urbana, University of Illinois Press, 1988), pp. 10-16 and passim. Stephen Thernstrom, Poverty and Progress: Social Mobility in a Nineteenth century city, (Cambridge, Harvard University Press, 1964) Passim. See also steve Dunwell, The Run of The Mill: A Pictorial Narrative of the Expansion. Domination Decline and Enduring Impact of the New England Textile Industry, (Boston: David R. Godine, 1978), pp. 3049. The Irish who labored to build Lowell's mills and canals were also the first immigrants to Manchester and Lawrence, where they also labored as builders. In all cities many of the Irish stayed on to work in the textile mills, where they replaced the Yankee farm girls. See Brian C. Mitchell, The Paddy Camps, for a history of the Irish and their labors and conditions in Lowell, which is applicable to Manchester and Lawrence, On the movement of the Irish from Lowell to Manchester and Lawrence to seek work see p. 79.

${ }^{2}$ Grace H. Blood, Machester on the Merrimack, the story of a City, (Manchester, NH, Lew A. Cummings Co, 1948), pp. $94,96,102,103,134$. George $W$. Browne, comp. . The Amoskeag Manufacturing Company of Manchester, New Hampshire, (Manchester, NH, Amoskeag Co, 1915), pp. 25, 31, 46, 61-63, $71,75$.

${ }^{3}$ Blood, Manchester, pp. 151-154, 185-188. Browne, Amoskeag Manufacturing Co, pp. 77, 81, 83, 97-108,

${ }^{4}$ Browne, The Amoskeag, pp. 114-116, 109. Figures for 1912 are taken from the chart "Statistics of 1912," on page 117. The figures for the peak, estimated to be in 1916, are from Tamara $K$. Hareven and Ralph Langenbach, Amoskeag: Life and Work in an American Factory City, (New York, Pantheon Books, 1978), p. 10. Figures for 1920 are from Amoskeag Manufacturing Co, Views and statistics of the Amoskeag, (Manchester, Amoskeag, 1920), unnumberd pages. See Also, Dunwell, Run of the Mill, pp. 119-128.

${ }^{5}$ Blood, Manchester, 244. Browne, Amoskeag Manufacturing Company, pp. 121-126, 133-134. Hareven and Langenbach, Amoskeag, p. 15, compare Manchester to the Pullman Company's 
control of Pullman Illinois or the control in southern mill villages. Views and statistics of the Amoskeag, contains the mortage offer of for one-half of the purchase price of the lots the company made available. If a house of no more than two tenements were built whithin one year it was interest free. At the end of five years if still in the house and employed at the Amoskeag, the second mortgage would be purchased for $\$ 1.00 ;$ and if after 10 years the same conditions were met the first mortgage was bought for $\$ 1.00$. The provision, although generous, would create property owners who had incentives to remain with the company and loyal to the company.

6 Hareven and Lagenbach, Amoskeag, p. 11.

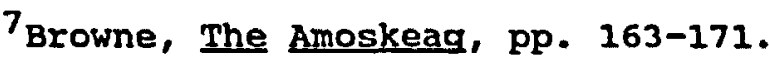

${ }^{8}$ Ibid., p. 170 .

${ }^{9}$ Hareven and and Lagenbach, Amoskeag, pp. 18-21. James P. Hanlan, The Working Population of Manchester, New Hampshire, 1840-1886, (Ann Arbor, University of Michigan Press, 1990), see especially tables 2.8-2.9, 3.1-3.7, 5.15.21, and 6.1-6.9. Figures checked with U.S. Census Population figures.

10 Hareven and Lagenbach, Amoskeag, pp. 16-17.

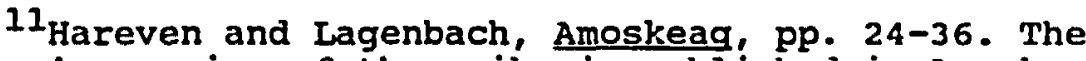
company's version of the srike is published in Amoskeag Manufacturing Comnpany, History of the Amoskeag strike During the Year 1922, Manchester, Amoskeag, Co, 1924.

12 Donald B. Cole, Immigrant city Lawrence, Massachusetts, 1845-1921, (Chapel Hill, The University of North Carolina Press, 1963), pp. 19, viii. Dunwell, Run of the Mill, pp. 82-85, D. Hamilton Hurd, comp. History of Essex County, Massachusetts, (Philadelphia, J.W. Lewis Co, 1888), pp. 861, 866.

${ }^{13}$ Hurd, History of Essex County, pp. 866, 868-871.

${ }^{14}$ Hurd, History of Essex County, pp. 889-897. Maurice B. Dorgan, Lawrence yesterday and Today, 1845-1918, (Lawrence, MA, Dick and Trumpold, 1918), pp. 146-162. Cole, Immigrant City, p. 177. Peter M. Molloy, The Lower Merrimack River Valley: An Inventory of Historic Engineering and Industrial Sites, (North Andover, MA, Merrimack Valley Textile Museum, 1978), pp. 22-44.

${ }^{15}$ Ardis Cameron, "Bread and Roses revisited: Women's Culture and Working-class Activism in the Lawrence strike of 1912," in Ruth Milkman, Women, Work, and Protest: A Century 
of US Women's Labor History, (Boston, Routledge and Kegan Paul, 1985), 46. The figures are arrived at using her population of 85,000 of which she says $75 \%$ were dependent on the mills, or 63,$750 ;$ and she says 608 were in the mills, or 38,250 . It should also be remembered that individuals who lived in Methuen also worked in the mills, most likely the Arlington Mills which stretched through Methuen.

${ }^{16}$ Cole, Immigrant city, p. 13 phrases it differently; In 1912 half of the population fourteen years of age and over worked in the factories and three-quarters of the city depended upon them, 113. In 1878 of the foreign born workers, 2,800 were born in Ireland, 1,400 in England, 700 in Canada, and 400 each in Germany and Scotland, 113. For other immigrants pp. 68-71; for Saxons, Silesians and Bavarians, p. 11. Population figures taken from Table I and Table IV, pp. 209-211. For 1910 the number born in French Canada was 7,698 , U.S Bureau of the Census, Thirteenth Census, 1910 , Population, p. 880 .

${ }^{17}$ Cole, Immiqrant City, pp. 177-183. Some expamples of the wage increases are: workers making $\$ 5.00$ a week were to get more than $\$ 6.00$, and operatives making $\$ 8.00$ were to get \$8.75. Ardis Cameron, "Bread and Roses Revisited," 43-56. William Cahn, Lawrence 1912: The Bread and Roses Strike, (New York, Pilgrim Press, 1977), passim.

${ }^{18}$ Cole, Immigrant City, pp. 184-194, 177-194. Ardis Cameron, "Bread and Roses," 43-57. There are a number of vivid and poignant descriptions of the actions of the women during the Lawrence strike in "Bread and Roses Revisited." The role of the women is further explored in Ardis Cameron, Radicals of the Worst Sort: Women in Lawrence Massachusetts, 1860-1917, (Urbana, University of Illinois Press, 1993).

${ }^{19}$ cole, Immigrant city, 201.

20 Ibid. , 196, 201, 203-05.

${ }^{21}$ Amoskeag Company, History of the Amoskeag Strike During the Year 1922, p. 27. Another description of conditions after World War $I$ and company wage and production policies can be found in George E. Kuhnhardt, Lawrence: $\underline{A}$ Manufacturef's View, (Boston: The Rockwell and Churchill press, 1919). Kuhnhardt, German by birth or origin, arrived in Lawrence from New York about 1885 and operated a specialty wool weaving company, which had good reputation. unfortunately, little is known of him.

22 Dero A Saunders, "The Twilight of American Woolen" Fortune, 49 (March, 1954), 92-96, 198-204. "New England's New Look," Fortune, 48 (October, 1953), 131-132. 
23 "New England's New Look," 131.

${ }^{24}$ Saunders, "Twighlight of American Woolen," 93.

25 Ibid., 92-96, 198-204.

$26 \mathrm{Julius}$ Stern, "From Hergenbock in Germany to Andover, Mass USA: Autobiobraphy of Julius Stern of Marum Knitting Mills, Lawrence Mass, (Unpublished at ICA, 86.17.1), 51-54. Stern operated hosiery mills in Germany and was fortunate to escape and to set up a similar mill in Lawrence.

27 Marc Scott Miller, Irony of Victory, World War II and Lowell, Massachusetts, (Urbana, University of Illinois Press, 1988), pp. 201-209, 134. Although dealing with Lowell, the same issues could be applied to Lawrence and Manchester, since the mills controlled the land and water rights in both cities.

Additional details about the decline of the textile mills in Lawrence can be found in: "Lawrence Revives--Part Way," Business Week, (June 10, 1950), 61-62. "Textile City Gets Along Despite Layoffs," Business Week, (May 7, 1949), 25-26.

28 Saunders, "Twilight of American Woolen," 93.

29 Miller, Irony of victory, quote is from an interview with James Ellis, June 16, 1975, p. 212 . 
CHAPTER IV

\section{SAXONY IN THE NINETEENTH CENTURY \\ FACTORS LEADING TO EMIGRATION}

Lawrence and Manchester, with their massive textile mills, gained reputations in Europe as places where one might find employment. If one were an experienced weaver, dyer, machinist, or loomfixer so much the better. If industries were stagnant or declining at home, perhaps there were opportunities in the two textile cities in America. During the last third of the nineteenth century Saxons and other southeastern Germans sought opportunities in the textile mills of Manchester and Lawrence. In time, Saxons may have made up as much as forty percent of the Germans living in the textile cities. ${ }^{1}$ and, among the saxons, they had previously lived in the smaller cities and towns rather than the Kingdom's major cities, Leipzig and Dresden. The opportunities to be found in Manchester and Lawrence as well as the conditions in saxony led to the emigration. ${ }^{2}$ and it is the socio-economic conditions in saxony that led to this migration which must now be explored.

During the eighteenth century, the kingdom of saxony had industrialized more than the rest of Germany. Textile industries developed first, experienced rapid growth after 1673, and became the dominant industry in the Kingdom. By 
the early 1800s, for example, the district of plauen became a center of printing on calico, cotton, and linen fabrics. 3

The Saxon government, either intentionally or through benign neglect, encouraged industrial growth. Monopolistic restrictions were allowed to break down, which resulted in the creation of corporations, and labor restrictions were eased, permitting workers to seek employment in the new factories. Thus, between 1774 and 1786 employment in muslin manufacturing increased from ten to twenty thousand in the Plauen Region. During the Napoleonic War, English textile machinery could not be imported and Saxon workers began copying the available machinery. After the war, however, Saxon machinery could not compete with England, and there was a gradual shift to the more skilled woolen production. 4

The Saxon ability to copy and build machinery, if not invent it, provided a means for mechanizing textile manufacturing. The earliest mechanized mills were established in Zwickau and the Vogtland around the turn of the nineteenth century. Mechanization of the textile process led to the growth of the metal and machinery industries. These factors led to the development of saxony as one of the early industrial areas of Germany, although this industrialization was based on textiles. For instance, over fifty-five percent of its industrial employment was in textiles. 5

Industrialization did not progress uniformly. Political conflict in the early nineteenth century affected saxon 
development. At the Congress of vienna, Saxony lost more than half of its territory and about three sevenths of its population, 6 and a rather mediocre monarchy was restored. Despite industrialization, many of the looms in the factories were actually hand looms, and as late as 1846 there were as many cotton looms in rural cottages as in the factories. The cottage weavers also farmed the small plots of land they owned. Furthermore, Saxon cloth was less competitive than that of the more mechanically advanced Britain. Therefore, one historian concludes that saxon industries were built on "an uncertain foundation, which could crumble quickly."7 spinning and weaving of textiles had long been a handwork and cottage industry in Saxony. Throughout industrialization, the rural, familial, and handwork character remained. However, as textiles became more mechanized the handwork and the skill levels it required declined, resulting in a lowering of wage rates. The transformation process may have been gradual lasting several generations, 8 especially in the textile industries of Glauchau and Meerane.

The combined rural and industrial nature of the Saxon Oberlausitz serves as an example of the change. The Oberlausitz region in extreme southeastern saxony bordered, Silesia (now in Poland) and Bohemia (now the Czech Republic), had a long history of producing woven cloth which continued to the end of the German Democratic Republic. In the nineteenth century, the largest city in the oberlausitz was 
Zittau, whose population almost tripled between 1834 and 1890. At the same time the the older weaving villages in the region remained stable. According to Jean Quataert, the Oberlausitz industrialized thoroughly without significant urbanization and large concentrations of the urban proletariat. Furthermore, the transition from hand to mechanized textile production had been gradual. 9 In the Oberlausitz, while zittau absorbed the increased population, in the villages weaving was done in the home hand weavers or in small factories. Nevertheless, the shift toward concentrated factory manufacturing in textiles continued. By the end of the nineteenth century almost seventy percent of the industrial work force in the south oberlausitz was employed in textiles. 10

During the middle of the nineteenth century, Saxony continued to industrialize and concentrate in textiles. Between 1849 and 1861, manufacturing employment in Saxony continued to grow much faster than in Germany, but it also continued to be concentrated in textiles. ${ }^{11}$ Although the indistry continued to mechanize, a zollverein tariff on cotton, in effect from 1847-1865, helped prevent thorough modernization. At the same time the traditional culture of work came under stress. In most areas of saxony, the Oberlausitz excluded, the cottage workers were finally forced out, either emigrating or moving to towns and factories. Especially hard hit was the Vogtland, in Saxony, and the Province of Silesia, where the weaver's plight was later 
dramatized by Hauptmann. 12 Workers, began to express antimechanization sentiments, which in a way were similar to those of the Luddites in England forty years earlier.

In the 1870 s and 1880 s the Saxors textile industry continued to mechanize. Even in the Oberlausitz, hand weaving was replaced by mechanized mills and the factory system by the end of the century. Saxon businesses increasingly relied on sufficient labor and water power to operate. The textile industry became more concentrated on weaving high quality woolens. clothing production increased and there was increased weaving of specialty goods of cotton and linen. During the same period the machine industry also grew. The industry which had long supplied textile machinery began to shift production to satisfy the needs of the railways and for export. Mechanization in both the textile and machinery industries began to change the skill levels of the workers. Handicrafts and artisans declined and many workers moved to factories, where there were few skilled positions, many more semi-skilled occupations, and an increasing number of unskilled positions. 13

Industrial jobs in Saxony encouraged in-migration from other parts of Germany. Between 1861 and 1882 the population of Saxony increased forty percent which was about twice the national average. 14 Germans, mainly from the east, moved to saxony to seek employment opportunities, and during those twenty years, 380,000 migrants or their children lived in 
Saxony. 15

Both Germany and Saxony suffered severely during the "Great Depression," which lasted from 1873-1896 in various parts of the industrialized world. Particularly bad were the periods from--1873-1879, 1882-1884, and 1891-93. Saxon textile employment dropped from 254,000 in 1861 to 204,000 in 1875. In Saxony, textiles no longer drove industrialization nor provided sufficient employment. An unanticipated additional factor negatively affecting the Saxon textile industry was the acquisition in 1871 of Alsace by the victorious and newly formed German Empire. Not only did these former French provinces have advanced textile industries, their capacity was almost half as much as the rest of Germany combined. The products of the new provinces were now on equal footing with the products of other German provinces. Tariffs could no longer protect saxon industry from cheaper or better cloth. Alsatian competition seems to have had a particularly disastrous impact on the vogtland region of Saxony. 16

Between 1880 and 1900 , the Ruhr industrial area surpassed Saxony as the industrial center of Germany. During these twenty years the textile industries continued to decline. Saxon population increased but not as rapidly as the industrializing Ruhr. For instance, the population of Saxony rose twenty-one percent, while the population of the Ruhr increased thirty-five percent. Jobs in Saxony still required relatively high skills, and the Ruhr was able to 
absorb the unskilled labor migrating from eastern Prussia. 17 Even though the relatively skilled Saxon workers received daily wages higher than the national average, an industrial worker could improve his conditions by moving to America. Wolfgang Helbich notes that real wages could be as much as three hundred percent higher in America than in Europe for skilled occupations. The cost of lodging in America reduced this differential some, but in America food and clothing were better. 18 As skilled saxon workers came to know this, either through letters they received from America, advertisements, or other means, they connected the opportunities with the the declining or stagnant conditions of their experiences and planned to emigrate.

Therefore, it is not surprising that a high number of German immigrants in Manchester and Lawrence were from Saxony. Further, many of them gained relatively high level jobs in the textile mills, such as weaver, machinist, or loomfixer, very soon after they settled. These immigrants were born in Saxony, and were not migrants to the Kingdom from East Prussia. The immigrants appear to have come from the more rural areas of saxony and not its major cities Dresden, Leipzig, and Chemnitz. They came from the Erzgebirge, and the towns of Annaberg and Schwartzenberg; from the Vogtland and its towns of Aue and Auerbach; they came from Plauen, Zwickau, Glauchau, and the even smaller towns of Hohenstein and Ernstthal and Meerane and Crimmitschau; and from zittau in the oberlausitz.19 such 
facts lend strong credence to Quataert's assertion that Saxony was industrialized but not urbanized.

In an attempt to determine if the textile companies in Manchester and Lawrence were actively recruiting textile workers from Saxony the reports of the U.S. Consulates in Saxony were searched. The representatives of the United States Government proved to be inaccurate, biased and inattentive and accurate, unbiased, and astute observers of the situation in saxony. At various times during the 1880s, the U.S. Government requested from its representatives information about textile manufacturing, conditions of labor, and emigration. 20

Consul James T. Mason, of Dresden, responded on July 27 , 1886 to a circular requesting information on emigration and complained of the difficulty in obtaining it from the departments in Saxony since it was not public. He wrote that obtaining the information required considerable work and research. His conclusion that the Saxons are a "happy contented people, satisfied with little," may be suspect, but his conclusion that the "Saxons are not an emigrating people, less so than other Germans, "21 may have been perceptive. Very perceptively he adds, "the causes of emigration are as various as emigrants are numerous. I should say, they are mostly due to the success of friends who have preceded them, and write for them."22 He reported that the government did not deport the insane or paupers, but provided for them in the kingdom. Neither did the government assist any groups or 
individuals to emigrate. He cites as causes of emigration, "compulsory military service, onerous taxation, strikes, surplus population and a desire of finding a better life."23 Furthermore, according to the Consul, the saxon Government does not "prevent emigration after one has performed his military service." 24 He then gives the number of emigrants to the United states from Saxony, and the chart is given in Table 4.1.

At first glance his figures appear low, but compared to a report from Consul wilson in Bremen they appear reasonably accurate. 25 They seem to show a higher proportion of males to females than is normally believed to be the case of Germans, who tended to emigrate in family units. However, since ages are not given it is hard to determine ratios of adults or children. The increase in emigration between 1871 and 1874 and 1879 and 1884 coincides with the arrival of Saxons in Manchester and Lawrence. The Saxon exodus peaked a year earlier than the highest year of German emigration, 1882 . 
TABLE 4.1

THE NUMBER OF EMIGRANTS TO THE UNITED STATES FROM SAXONY 26

\begin{tabular}{lrcr} 
YEAR & MALES & FEMALES & TOTAL \\
1871 & 1114 & 770 & 1884 \\
1872 & 1534 & 907 & 2441 \\
1873 & 1458 & 957 & 2425 \\
1874 & 628 & 439 & 1067 \\
1875 & 474 & 271 & 745 \\
1876 & 469 & 216 & 685 \\
1877 & 447 & 230 & 677 \\
1878 & 529 & 270 & 799 \\
1879 & 894 & 420 & 1314 \\
1880 & 2474 & 1418 & 3892 \\
1881 & 5701 & 3240 & 8941 \\
1882 & 4294 & 3045 & 7249 \\
1883 & 3564 & 2462 & 6026 \\
1884 & 2685 & 1793 & 4478 \\
\hline
\end{tabular}

Source: Consular Dispatches, Dresden (T383), July 27, 1886, Number 180 .

Consul Mason's figures are an important source of information about emigration from saxony during this period. 27 In 1882, with a population of approximately $3,105,000$, the kingdom of saxony made up about about six percent of the population of the German Empire. 28 The 7,249 Saxon emigrants to the United States in 1882 represented about one-fourth of a percent (0.233) of the population of the Kingdom. The 250,000 German immigrants to the United States represented about one-half a percent $(0.483)$ of the population the German Empire $(51,750,000)$. Emigration from Saxony was slightly less than its proportion of the German population, ranging from about 1.22 to $4.6 \%$ of total German emigration. However, the Saxon emigrants through Bremen represented a slightly higher percentage (3.72 to 5.23$)$ of the 
Germans emigrating through that port. 29 Consul Mason also gave some indication of the occupations of the emigrants, and in both 1883 and 1884 his category of "clerks and skilled laborers" outnumbered his "agricultural and forestry" category ten to one. ${ }^{30}$ The high concentration of saxons in the northern New England textile cities is significant given their proportion to total German emigration to the United States. Comparisons are given in Table 4.2 .

TABLE 4.2

COMPARISON OF SAXON EMIGRATION AND GERMAN EMIGRATION 31

$\begin{array}{lrrr}\text { YEAR } & \text { GERMANS } & \text { SAXONS } & \text { SAXONS } \\ 1871 & & & \\ 1872 & 82,554 & 1,884 & 2,28 \\ 1873 & 141,109 & 2,441 & 1.73 \\ 1874 & 149,671 & 2,425 & 1.62 \\ 1875 & 87,291 & 1,067 & 1.02 \\ 1876 & 47,679 & 745 & 1.56 \\ 1877 & 31,937 & 685 & 2.14 \\ 1879 & 29,298 & 677 & 2.14 \\ 1880 & 34,602 & 799 & 2.73 \\ 1881 & 84,638 & 3,892 & 4.60 \\ 1882 & 210,485 & 8,941 & 4.25 \\ 1883 & 250,630 & 7,249 & 2.89 \\ 1884 & 194,786 & 6.026 & 3.09 \\ & 179,676 & 4,478 & 2.49\end{array}$

Source: Historical statistics of the United States, 1975. Series c89-119, p. 106; and Consular Dispatches, Dresden (T383), JuIy 27, 1886, Number 180 .

In 1888, Consul Mason again responded to a state Department circular regarding emigration. He reported once again that the "Saxons are not an emigrating people," since "the country is very prosperous... [with] manufacturers of all sorts." 32 Unfortunately, he did not include an update of his statistics similar to those in the earlier report. It was 
fortunate for America he added that "the few who come under my notice emigrating to the United states have invariably been desirable." Some were mechanics and others [in] agriculture who were invited to our shores by the success of relatives and friends." 33 In an important observation he notes that:

Such immigration was invariably and entirely free and voluntary, and in no instance I could ever learn, stimulated or encouraged by transport companies, industries, societies or associations, of any kind.

I have never known of any assisted emigration from Saxony. I have made diligent enquiry and investigation and have been unable to discover any such emigration by any individual association or corporation or municipalities.

The importation of labor under contract, thereby evading our laws, does not exist in saxony. on the contrary, it is against the laws here to entice or endeavor to procure emigration by any device, and such conduct would incur prompt arrest and punishment from the Royal Government. 34

Consul Mason further reports that:

Artisans, mechanics, or skilled laborers do not [go] to the United States for the purpose of temporary employment during certain seasons of the year, and return at the expiration of such employment; but go in good faith to become citizens of the United States.

They are good people and will prove beneficial and profitable acquisitiogs to our labor, and become good citizens....

Consul Mason answered several questions in the minds of American policy makers. The emigration from Saxony was free and not assisted by the saxon Government nor by contract labor agents. Saxons were not migrant workers. The Consul 
clearly believed that the Saxons would be good additions to the United states. At that time nativist concerns were being raised about southern and eastern European immigrants. Such beliefs were clearly articulated in a dispatch from a Consular Agent in Gera. 36 Consul Mason could recognize the skilled laborers among the emigrants, but still had some of the late nineteenth century beliefs in the frontier farmer. Consul Mason did recognize what is now called chain-migration through the letters to and assistance to saxons from relatives already in America. Since many of the emigrants may have been from the smaller towns, the Consular office in Dresden may have had no contact with them. This could have led to the presumption that few Saxons were emigrating. During the 1880s, the state Department also requested information from its consuls regarding textile manufacturing, labor, and wages. Apparently, there was concern that Saxon textile mills were selling cloth in the United states below the cost of manufacturing (i.e. "dumping goods"). The U.S. Consuls responded with some very detailed reports, sometimes even including cloth samples. These reports give a glimpse of the capacities and mechanization of the textile industry in saxony, the level of wages, and some of the social and economic conditions, especially during times of depression.

A December, 1881 Circular requested statistical information about cotton and woolen industries. On June 3 , 
1882 Consul J. Egliston Montgomery of Leipzig addressed a report to Assistant Secretary of State John Davis. The Consul apologized for the delay in responding and explains his attempts to obtain the information, which he attempted to get from the Chief Bureau of Statistics in Saxony, the Chamber of Commerce, and from several fricndly manufacturers. He reported that he had not met with much success. The manufacturers felt that to provide the information would somehow lead to an increase in competition or in higher taxes. Moreover:

The principal proprietors cannot be convinced that there is not some ulterior design or purpose in this desire to obtain such a thorough insight into the present system of employment and labor in Germany, the result of which in their opinion can only be to induce an erigration of speratives to America by comparison of wages and advantages furnished. Emigration from this country is now so great that it is scarcely (illegible) that every attempt to secure statistical information concerning labor for publication in the United states should excite suspicion as to its purpose. 37

Montgomery in Leipzig, unlike Mason in Dresden, recognized the extent of the enigration from Saxony. The local mill owners clearly feared that the publication of or implication of better conditions in America would cause them to lose labor. The owners preferred not to have to replace laborers or raise wages to hold them. They recognized that saxon workers were transferring job skills and experiences to textile mills in America.

Consul Montgomery was able to append to his letter a 
report of two woolen factories in the suburbs of Leipzig. The Littel and Krüger worsted was noted for the high quality of its export goods. The firm had attended trade fairs in Vienna, Santiago, Philadelphia, Sydney, and Leipzig. The company's exports to the United States were "limited in quantity, amounting to about $\$ 19,500$ last year."38 $\mathrm{Mr}$. Montgomery continued his report giving information on the steam powered mill, which covered 1,300 square meters in four buildings employing approximately 400, of which 350 were females. The operatives worked eleven hours a day for six days a week. Wages were $\$ 3.10$ to $\$ 4.25$ per week for males and $\$ 1.90$ to $\$ 2.87$ a week for females. The plant used 500,000 pounds of wool per year to produce cloth. 39 Consul Montgomery also visited a large factory, "Kammgaurspinnerei" (sic), which manufactured carded wool. The company had capital stock of $\$ 535,000$ in shares of $\$ 75$ each and paid a thirteen percent dividend for the year. The mill covered an area of $121 / 4$ acres employing 600, of which 150 were males earning $\$ 4.75$ to $\$ 7.10$ week and 450 females earning $\$ 2.15$ to $\$ 2.86$ per week. The mill used ten tons of coal a day to provide steam to 86 combing machines and 38,000 spindles producing $1,650,000$ pounds of finished products a year. 40 In sum, these mills were no Amoskeag, but they compared favorably in size to some of the smaller mills in Lawrence. Moreover, a worker leaving these mills and entering one in Manchester or Lawrence would be in very similar surroundings if at a larger scale. Such a worker could easily transfer 
skills as a weaver, machinist, or loomfixer.

Another Consular report provides additional insights. In 1885, Consul George Tanner of Chemnitz forwarded a report on textile and agricultural labor. Like his counterpart, he also reported difficulties in obtaining information. One reason was that "it is a well known fact that scarcely two manufacturers here pay for labor alike."41 Also the manufacturers "prefer selling below market price to America."42 Consul Tanner visited the Kratz and Bork cotton mill, which covered 4,525 square hectares, and was powered by steam. The power looms, of which there were 218, appeared to have been mostly English imports. Its approximately 230 employees produced 18-20,000 meters of cloth a week. They worked 65 hours a week, and the average weekly payroll was $\$ 833$ (or an average of about $\$ 3.62$ per worker) .43 In size this plant was a dwarf compared to the Amoskeag, but skills could be transferred from Kratz and Bork to the Amoskeag or the Arlington Mill.

While the Consuls gathered such information they made observations about the labor, economic, and social conditions in Saxony.

In 1878 Consul Mason of Dresden sent a dispatch outlining the harsh economic conditions that year. He reported that the cost of living went up with wages, and that the "workers seem improvised..." In the farming communities it was "common to engage in some trade...to earn money, but conditions were so bad that such activities were not 
possible."44 In the cities, the flats were,

...generally very unhealthy and uncomfortable.

[Furthermore],

The food is mostly of potatoes, black rye bread, a coffee made of chicory, gruel or broth, and very little meat, and very seldom too.

The present state of trade is desperately depressed; universal complaint is heard on all sides, and the contraction experienced with us since 1873 had been more severely felt in Germany. 45

Five years later, Consul Tanner enclosed with his report on textiles a report on the conditions in saxony. He noticed that power looms were replacing hand looms, which he considered "cheap labor."46 In his opinion, "...the weavers seem worse off today than they were five years ago... wages here declined owing to the great competition." 47 He interviewed a worker who stated,

I am 62 years old and have worked in one factory about twenty-five years. On average I earned about $\$ 3.00$ a week. For the last five years I have not been able to earn more than $\$ 1.50$ per week, owing to the long ${ }_{8}$ pauses and the work being given to younger men.

The Consul estimated minimum weekly living expenses to be between $\$ 1.17$ to $\$ 3.42$. Despite such economic conditions, "strikes are unknown in this consular district." 49 Here is a clear indication through observation by the consul and a statement of the worker, that conditions were deteriorating for workers in Saxony.

German emigration varied to some degree in the late nineteenth century with the economic conditions in both 
Germany and the United states. It tended to decline during times of recession in America. Departure from Germany was possible by saving from work during the economic upswings, selling the farm to gain passage money, or receiving a prepaid ticket from relatives in America. The conditions in Saxony were such that in the 1870's and 1880's a large number of Saxons were emigrating. In the opinion of Consul Tanner of Chemnitz:

\footnotetext{
...the social class that emigrates is very low... and are full of lice and vermin. They have nothing but a crust of dark bread... and spend all they earn on hard liquors... and live on seven or eight cents a day. [Even the] ... better class of emigrants... who [are] mechanics....are not the best artisans in Germany. The better class of German workmen remain at home, that is a well known fact. 5
}

It would appear that they were well regarded by textile mill owners in America. They were certainly more skilled and apparently better regarded than many other immigrant groups. They were able to transfer the skills learned in the factories of Saxony to the factories and mills of Northern New England. 51

Nineteenth century Saxon industry dominated by textiles and the related machinery industries felt the impact of the Great Depression severely. The decline of the industry displaced a number of workers. Furthermore, even during the short economic upturns there was not enough work for the available laborers. Mechanization had compressed the skill levels leading to more uncertain employment and lower wages. 
Faced with the conditions described by the U.S. Consuls and dramatized by Hauptmann, a number of Saxon weavers, machinists, and loomfixers, packed up and left for work in the famous textile centers of Manchester and Lawrence. 
CHAPTER NOTES

CHAPTER IV

${ }^{1}$ It will be shown that a large number of the immigrants to Manchester and Lawrence came from Saxony and that many held skilled positions in the mills such as weaver, machinists, dyer, with a number advancing to supervisory positions. Full details are in chapter $v$.

See also Kamphoefner, "'Entwurzelt' oder 'Verpflanzt'? 332 ; and Kamphoefner, The Westphalians, p. 84. Kamphoefner states that relatively larger number of Saxons settled in New England, as compared to the general origins of German emigrants.

See also, U.S. Census office, Ninth Census, 1870, Population. In 1870 there were 467 Germans in tawrence of which 174 were from Saxony (37.2\%), from Prussia 154 (32.98), from Baden 34 (7.28\%), and from Bavaria (6.63\%). U.S. Census office, Tenth Census, 1880 , Population, there were 1,117 from Germany, and from Saxony 473 (42.34\%), from Prussia (19.428), from Nassau $44(3.93 \%)$, and from Bavaria (2.86\%). Such a breakdown is not reported for Manchester. From the 1880 Census Manuscript schedule for Manchester similar ratios can be calculated. of appproximately 250 Germans identified, 83 were from Germany and from Saxony 62 , (24.8\%).

2 The conditions in saxony were the "push" factors, and the real or perceived advantages were the "pull" factors of emigration. Philip Taylor, The Distant Magnet, pp. 66-106. Roger Daniels, Coming to America, p. 17.

${ }^{3}$ Frank B. Tipton, Jr. Regional Variations in the Economic Development of Germany During the Nineteenth Century, (Middletown, CT, Wesleyan University Press, 1976), pp. 30-31.

${ }^{4}$ Tipton, Regional Variations, pp. 33-35.

${ }^{5}$ Ibid., p. 38.

6 Tipton, Regional Variations, pp. 30-38. Mack Walker, German Home Towns: Community, State, and General Estate, 1648-1871, (Ithaca, Cornel1 University Press, 1971), pp. 120$25,208-210$.

${ }^{7}$ Walter 0 . Foster, Zion on the Mississippi: The Settlement of the Saxon Lutherans in Missouri, 1839-1854. (St. Louis, Concordia Publishing House, 1953), pp. 6-7, 8-9. 
Saxony, which was a part of the German Confederation created by Napoleon, sided with Napoleon in the Wars. Prussia had made a deal with Russia to get Saxony in exchange for Russia obtaining parts of Poland. At the Congress of Viennia, Prussia received that part of the kingdom which became the Province of Saxony-Anhalt, but it did not get the whole Kingdom.

8Tipton, Regional Variations, p. 38. Similar conditions existed in the textile producing areas of switzerland in the 1820's. Leo Shelbert. "On Becoming an Emigrant: A Structural View of Eighteenth- and NineteenthCentury Data," in Perspectives in American History:

Dislocation and Emigration, the Social Background of American Immigration. VII, (1973), 452-454.

${ }^{9}$ Jürgen Kocka, "Working-class Formation in Germany: The Early Years, 1800-1975," in Working-Class Formation: Nineteenth-Century Patterns in Europe and the United States, eds. Ira Katznelson and Arstride R. Zolberg, (Princenton, Princeton University Press, 1986), 303.

${ }^{10}$ Douglas R. Holmes and Jean H. Quataert, "An Approach to Modern Labor: Worker Peasantries in Historic Saxony and the Fruili Region over Three Centuries," Comparative Studies in Society and History, 28 No. 2 (April, 1986): 191-216; Jean H. Quataert, Combining Agrarian and Industrial Livelihood: Rural Households in the Saxon Oberlausitz in the NineteenthCentury," Journal of Family History, 10 (Summer, 1985): 145-62: and Jean H. Quataert, "Politics of Rural Industrialization: Class, Gender, and collective Protest in the Saxon Oberlausitz of the Late Nineteenth Century," Central Europen History, 20 (June, 1987): 91-124.

${ }^{11}$ Quataert, "Politics of Rural Industrialization," 100, $104,105,98$. Holmes and Quataert, "Worker Peasantries in Saxony," 201.

12 Tipton, Regional Variations, pp. 37-38. saxon textile employment increased from 337,000 in 1849 to 457,000 in 1861. Between 1849 and 1861 , manufacturing employment in Germany increased twenty-one percent, while in Saxony the increase was thirty-five percent: and in Saxony textiles employment rose thirty-four percent.

13 Jürgen Kocka, "Working Class-Formation in Germany," 303. A literary portrayal example of the conditions of the mid-century weavers, although set in silesia but relevant to Saxony, is by Gerhart Hauptmann, The Weavers: A Drama of the Forties, (New York, B.W. Huebisch, 1911), Trans by Mary Morison.

14Tipton, Regional Variations, pp. 48-53. 
15 Ibid., p. 52. Between 1861 and 1882 the population of Saxony rose $44 \%$ or nearly twice the national average. In 1882 about 380,000 migrants, or children of migrants were in Saxony from other regions

${ }^{16}$ Nolan, "Economic-Crisis, state Policy, and Workingclass Formation in Germany," in Katznelson and zolberg, eds, Working-Class Formation, p. 355. Tipton, Regional Variations, pp. 48-49. Gustav Stolper, The German Economy, 1870-Present, (New York, Harcourt, Brace and World, 1967), pp. 19, 36.

17Tipton, Regional Variations, pp. 122, 123, 124, 125.

18 Wolfgang Helbich, "The Letters They sent Home: The Subjective Perspective of German Immigrants in the Nineteenth Century, Yearbook of German American studies, 22 (1987): 9 .

${ }^{19}$ The information about the immigrants and their town of origin and the transfer of skills will be explored in more detail in the next several chapters. Except for 1870 and 1880 when immigrant origin in German Principalities was listed for certain large cities, state origins of Germans cannot be determined for Manchester and Lawrence. Manuscript Census data also proved to be unreliable. Town of origin was gleaned from the obituaries in the Anzeiger und Post from 1886 to 1942 . This information is considered rather reliable. After about the mid 1920's place of birth began to be reported as a province or Germany rather than by town. There is little to indicate that the individuals left their villages or towns to live in Dresden, Leipzig of Chemnitz. It is most likely that they emigrated directly from the village.

${ }^{20}$ In Saxony there were United states Consulates in Annaberg (dates of reports 1882-1906, roll number T529), Chemnitz (1867-1906, T380), Dresden (1837-1906, T383), Glauchau (1891-1906, T572), Leipzig (1826-1906, T215), Plauen (1887-1906, T536), Zittau (1897-1906, T709). Also reviewed between 1875 and 1895 were Berlin (1865-1905, T163), Bremen (1794-1906, T184), Hamburg (1790-1906, T211), and Munich (1833-1906, T261). Also reviewed were Carlsbad (1902-1906, T540) and prague, Czechslovakia (1896-1908 T663).

Charlotte Erickson, American Industry and European Immigration, 1860-18885, (New York, Russell and Russell, 1967), p. 133 states that the textile mills in Lowell and Lawrence were "Said to be using steamship companies to supply them with immigrant workers," including "agents in Hannover and Holstein." Neither location is in Saxony, which had restrictions on agents, and neither was an embarkation city. Hannover could be along the route from saxony and other regions of southern Germany to Bremen or Hamburg.

Amoskeag records searched at the Manchester Historic Association and the Baker Library at Harvard University 
indicate no direct evidence of this. There are fewer

relevant records from the Lawrence mills, but those searched also give no conclusive evidence of such recruitment.

${ }^{21}$ Consular Dispatches, Dresden (T383), July 27, 1886, Number 180 .

22 Ibid.

23 Ibid.

${ }^{24}$ Ibia.

25 Ibid.

${ }^{26}$ Consular Dispatches, Bremen (T184), January 16, 1885, Number 118, from John Wilson gives the following emigration figures:

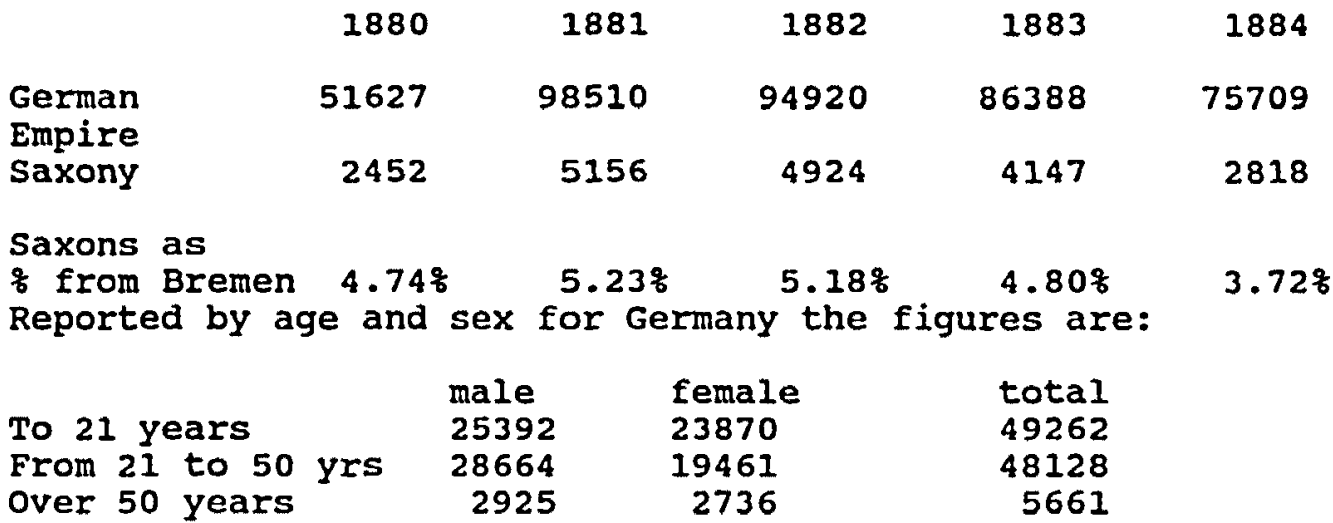

The figures are for Bremen only. It would appear that the figures for Saxony would be relatively accurate, since a number would have embarked in Hamburg. They also show slightly higher number of emigrants in 1881 than in 1882 . Sex ratios are almost identical for the under 21 and over 50 age groups, suggesting family movement. The higher number of males in the 21-50 age range would suggest young men, or family heads moving to establish jobs overseas. Of the 5,156 Saxons reported for $1881,5,092$ went to the United States, 45 to Brazil, and 19 to Argentina.

There is some discrepency in emigration figures from

Germany. Marschalck, Deutsche uberseewanderung im 19

Jahrhundert, p. 36 gives the emigration figure from Germany in 1882 as 220,900 . The Commonly held United States figure is 250,000. See also, Bade, Die Deutschen überseeische Massen Wanderung, pp. 265-269.

27 Much of the material dealing with Saxon emigration end their accounts prior to the 1880s, such as: L. Pohle, 
"Auswanderung und Auswanderungs Politik im Konigreich Sachsen," in Auswanderungs politik in Deutschland: Berichte, (Leipzig, Verlag von Dunder und Hombolt, 1892), 353-386; and Hildegrad Rosenthal, Die Auswanderung aus Sachsen im 19. Jahrhundert (1815-1871), (Stuttgart: Ausland und Heimat Verlags, 1931). Also a letter from Professor Günter Moltmann to the author May 22, 1992 indicated little specific information in the University of Hamburg studies on Saxon emigrants.

28 Tipton, Regional Variation, 170-202. Calculated from his statistical tables.

${ }^{29}$ Consular Dispatches, Bremen (T184), January 16, 1885 , Number 118, from John Wilson.

$\begin{array}{lllll}1880 & 1881 & 1882 & 1883 & 1884\end{array}$

Saxons as

$\begin{array}{llllll}8 & \text { from Bremen } 4.74 \% & 5.23 \% & 5.18 \% & 4.80 \% & 3.72 \%\end{array}$

See footnote 24 above.

${ }^{30}$ Consular Dispatches, Dresden (T383), July 27, 1986, Number 180. In 1883 "Clerks and Skilled Laborers" $=563$, and "Agricultural and Forestry" $=58$; in 1884, skilled $=568$, Agriculture $=54$.

${ }^{31}$ Bureau of the census, Historical statisics of the United States, p. 106, and Consular Dispatches, Dresden (T383), July 27, 1986, Number 180 .

${ }^{32}$ Consular Dispatches, Dresden (T383), September 13, 1888, Number 214 .

${ }^{33}$ Ibid.

${ }^{34}$ Ibid.

35 Ibid.

${ }^{36}$ Consular Dispatches, Leipzig (T215), September 20, 1888. The Consul in Leipzig forwarded a report from Consular Agent Neuer of Gera. Agent Neuer proposes strict control of emigration especially on emigrants from Italy, Bohemia, Poland and Russia.

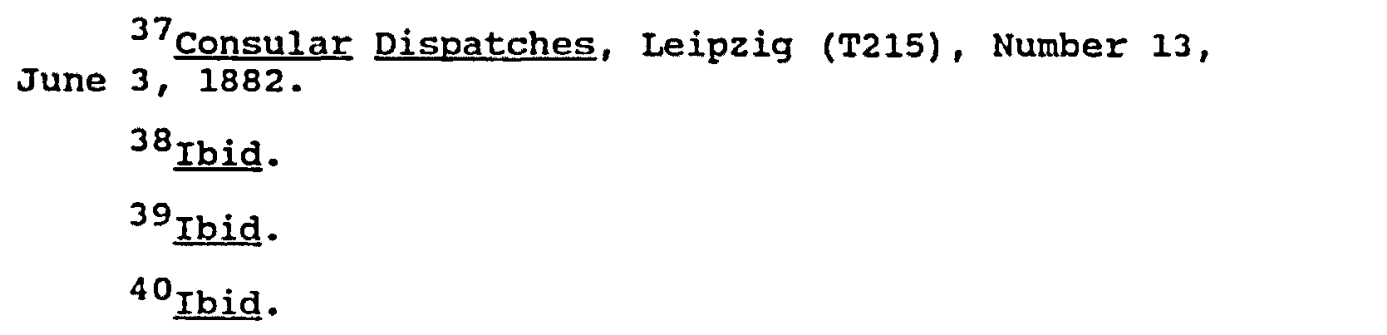


${ }^{41}$ Consular Dispatches, Chemnitz, (T380) Number 38 , December 12, 1885.

42 Ibid.

${ }^{43}$ Ibid.

${ }^{44}$ Consular Dispatches, Dresden (T383), Number 55 ,

July $31,1878$.

45 Ibid.

${ }^{46}$ Consular pispatches, Chemnitz, (T380) Number 38 , December 12, 1885.

47 Ibid.

48 Ibid.

49 Ibid

${ }^{50}$ Consular Dispatches, Chemnitz (T380), Number 52, May 28, 1886.

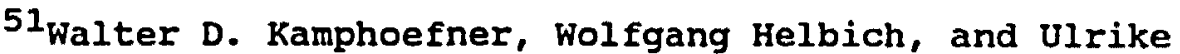
Sommer, eds. News From the Land of Freedom: German Immiqrants Write Home, (Ithaca, Cornell University Press, 1991), trans Susan Carter Vogel, pp. 335-351. The letters of Martin weitz are included. Martin Weitz a wool weaver left Hesse in 1854 and arrived in New York. In 1855 he moved to Rockville in southwestern Connecticut, a famous wool and cashmire center, and obtained a position as a weaver. 
CHAPTER V

ESTABLISHMENT AND EARLY GROWTH OF GERMAN COMMUNITIES IN MANCHESTER AND LAWRENCE, 1870-1899

The Germans who settled in Maine and Massachusetts during the Colonial era, those who came after the Napoleonic Wars, including the intellectual emigrés, the Dreissigers, and the Forty-Eighters--all these hypassed Manchester and Lawrence. Although a few Germans were present in the 1860s, the two textile cities were open territory for whatever Deutschtum the new settlers would establish. Germans began arriving in the 1870s, worked in the mills, established businesses, and started Vereine. Many more would come during the 1880s and the 1890s, expanding Deutschtum in the two textile cities. 1

The German populations of Manchester and Lawrence never comprised a significant proportion of the total population, or even of the foreign born population, as did the Germans who settled in the major cities of the Midwest. They formed, however, important and influential ethnic communities, whose residents made economic, social, and political contributions to the cities, and established active and thriving Vereinsleben. In Manchester, the Germans lived on the West side, in an area known as the "Squog," for the small tributary of the Merrinack River, the Piscataquag. In 
Lawrence they settled north and east of the common, in an area known as "Hallsville," and onto Prospect Hill, and the area was locally called "Dutch Gap." (See maps in Appendix). These neighborhoods remained relatively small and stable. Over time, Germans in Manchester would move further up the hill on the West Side and along the piscataquog. In Lawrence they would fill in Prospect Hill and move into adjacent Methuen. Neither section was exclusively German, however. In Manchester, French Canadians and Irish also Iived on the West side; and in Lawrence in addition to those groups, the Scots Iived in the German area.

The German-Americans in Manchester and Lawrence can be investigated together. In addition to arriving during the same period, many of the immigrants came from the same towns in Germany, especially from Saxony, and in many cases they were related to one another. Individuals moved back and forth between the cities for work or business, and Germans from Manchester and Lawrence intermarried. The Germanlanguage newspaper, Anzeiger und Post served both cities, and the Vereinsleben included mutual visits between the cities. The German-American populations of Manchester and Lawrence are summarized in Tables 5.1 and 5.2. Included in Table 5.1 are the total, the foreign-born, and the Germanborn populations of Manchester and Lawrence. Table 5.2 shows the total German-American population of Manchester and Lawrence, which is calculated by adding the German-born and those of Ge Iman parentage. It does not take into 
consideration the third generation, the children whose grandparents were born in Germany.

Several conclusions can be drawn from these statistics. First, the German population in relation to the total population, or even the foreign-born population of the cities was small. In 1860, the number of German residents of both cities was very small. The number of German born begins to increase particularly after 1880 , confirming the increased immigration during this period. Overall emigration from Germany declined after 1890, but in Manchester and Lawrence the number of German-born continued to rise after 1890, indicating continued immigration. There are strong indications that family members arranged for additional family members to join them in Manchester and Lawrence, and helped them find housing and jobs--a classic pattern of chain migration. Therefore, migration in the 1890 s represents additional family members migrating to the textile cities. After 1910 the number of German-born residents declined, showing that new immigrants did not replace the older immigrants. Since, the total German-American community was relatively small, the ability of Germans to keep Deutschtum alive for so long is quite an achievement.

Several conclusions can be drawn from the relationship between the German ethnic community, the total populaticn, and the foreign born. Although the number of German-born residents reached their highest point in 1910, their highest position in relation to the total population and the foreign 
TABLE 5.1

GERMAN POPULATIONS OF MANCHESTER AND LAWRENCE ${ }^{2}$

MANCHESTER

\begin{tabular}{lllllll} 
Year & Pop & $\begin{array}{l}\text { Foreign } \\
\text { Born }\end{array}$ & $\begin{array}{l}\text { German } \\
\text { Born }\end{array}$ & Pop & $\begin{array}{l}\text { Foreign } \\
\text { Born }\end{array}$ & $\begin{array}{l}\text { German } \\
\text { Born }\end{array}$ \\
1860 & 20109 & 5480 & $105 \star$ & 17639 & $7125 *$ & $256 *$ \\
1870 & 23536 & 7158 & $250 \star$ & 28981 & 12717 & 467 \\
1880 & 32630 & 12479 & $457 \star$ & 38270 & 17266 & 1117 \\
1890 & 44126 & 20091 & 892 & 44654 & 20518 & 1830 \\
1900 & 56987 & 24257 & 1124 & 62559 & 28577 & 2465 \\
1910 & 70063 & 29708 & 1225 & 85892 & 41319 & 2301 \\
1920 & 78384 & 27516 & 1007 & 94270 & 39063 & 1644 \\
1930 & 76834 & 21944 & 832 & 85068 & 28633 & 1330 \\
1940 & 77688 & 17396 & 585 & 84363 & 22939 & 915 \\
$\star$ Estimates. & & & & & \\
\hline
\end{tabular}

Source: U.S. Population Tables from 1860-1940. Estimates calculated from the Manuscript Census Lists.

TABLE 5.2

TOTAL GERMAN-AMERICANS ${ }^{3}$
LAWRENCE

Foreign German $256 *$ 467 117 830 465 2301 644 330 15

\begin{tabular}{|c|c|c|c|c|c|c|}
\hline \\
\hline \multicolumn{7}{|c|}{ TABLE 5.2} \\
\hline \multicolumn{7}{|c|}{ TOTAL GERMAN-AMERICANS ${ }^{3}$} \\
\hline \multicolumn{4}{|c|}{ MANCHESTER } & \multicolumn{3}{|c|}{ LAWRENCE } \\
\hline & $\begin{array}{l}\text { GERMAN } \\
\text { BORN }\end{array}$ & $\begin{array}{l}\text { GERMAN } \\
\text { PARENTS }\end{array}$ & $\begin{array}{l}\text { GERMAN } \\
\text { AMERIC }\end{array}$ & $\begin{array}{l}\text { GERMAN } \\
\text { BORN }\end{array}$ & $\begin{array}{l}\text { GERMAN } \\
\text { PARENTS }\end{array}$ & $\begin{array}{l}\text { GERMAN } \\
\text { AMERIC }\end{array}$ \\
\hline 1890 & 883 & 1366 & 2249 & 1830 & 2930 & 4760 \\
\hline 1900 & 1124 & 2146 & 3270 & 2465 & 4705 & 7170 \\
\hline 1910 & 1225 & 2198 & 3423 & 2301 & 4924 & 7225 \\
\hline 1920 & 1007 & 2330 & 3337 & 1664 & 3979 & 5643 \\
\hline $\begin{array}{l}1940 \\
\text { GERMAN- } \\
\text { generat }\end{array}$ & $\begin{array}{l}585 \\
\text { AMERIC = } \\
\text { ions. }\end{array}$ & $\begin{array}{l}1227 \\
\text { German-Am }\end{array}$ & $\begin{array}{l}1819 \\
\text { ricans, }\end{array}$ & he first- & $\begin{array}{l}1992 \\
-\quad \text { and sec }\end{array}$ & $\begin{array}{l}2907 \\
\text { ond- }\end{array}$ \\
\hline
\end{tabular}

Source: Compiled from U.S. Census Population Tables. 
born population came in 1900. To a certain extent the small size of the German enclaves, and the small number of Germans helps to explain their continued Deutschtum. There was much more contact between Germans from different regions and of different faiths. The leaders and members of the German community likely knew one another. Yet, so few Germans in relation to the total population of the cities meant that their ethnic characteristics gradually wore away.

The gradual downward trend of population in both cities beginning in 1920 is indicative of movement to neighboring towns and the reduced job opportunities occurring at this time. A home in Bedford or Goffstown in New Hampshire, or parts of Methuen or in Andover in Massachusetts was considered more desirable than living in the city. 4 This would indicate upward mobility for those who moved. Although some Germans moved out, many remained since they owned small homes and shops. If not the most exclusive neighborhoods of the cities, theirs were decent residential areas.

It is especially noteworthy that Germans did not settle in Lowell, the famous textile city only twelve miles up river from Lawrence. In 1900, the number of native Germans living in Lowell was only $164 !^{5}$ It would seem that Lowell also should have attracted textile workers from Germany. There is no complete explanation as to why it did not. One reason may be that Lowell developed earlier in the century than Manchester and Lawrence. The result might have been a differential in employment opportunity. The earlier 
immigrants found opportunities in Lowell, whereas the later immigrants found better opportunities in Manchester and Lawrence, at the very time those two cities were growing into textile giants. The skills of the German immigrants in weaving, dyeing, and loomfixing may have been in particular demand in the two newer textile cities. The first immigrants may have written home describing their ability to obtain jobs, encouraging further emigration, and may have sent passage funds home. Manchester and Lawrence were gaining reputations in German towns as textile centers. Confirmation of this reputation may be contained in a Saxon newspaper report:

60 to 70 years ago the weavers and their families suffered greatly from poverty through-out most of Germany's industrial areas. Their numbers were declining. At the first meeting of German weavers in Berlin... [there were] delegates from Werdau and Crimmitschau. The conditions of poverty led the polemicist August Bebel to deliver a powerful speech urging German factory workers to unite in an international effort. Ten years later, in 1881, weavers emigrated to North America for the promises of "golden mountains" They found work in the factories in Masachusetts where the looms were driven by the water of the Massachusetts river. The weavers who had learned their trade in their native country, according to the rules of their fathers' guilds, received nothing for a month's work. Therefore they moved to factories in Pittsfield, Lawrence, and Manchester. They worked for 12 hours without a breakfast or Vesper break for $1 / 2$ a dollar a day. As a result of their shocking letters home, Reichstag delegates Fritsche and viereck travelled to America at the request of the workers party to study American working conditions. It was during this time tht the poet Hauptmann wrote his play "The Weavers" which was based on the conditions at that time in Silesia. 6

Unfortunately, there are no known copies of the letters 
surviving. 7 Bebel and the worker's parties were most interested in improving labor conditions in Germany. Two objectives probably motivated the Reichstag investigation. one was a concern about the workers, who were still considered German citizens. Secondly, it was probably hoped that by showing conditions to be bad in America, emigration would be stopped. However, almost from the beginning of emigration there were reports and investigations about poor conditions in America. Mack Walker concludes that all the official and press reports which were usually unfavorable to America did not stop emigration. 8 The fact was that saxons continued to migrate to Manchester and Lawrence for jobs in the textile mills.

Furthermore, there was work in Manchester and Lawrence as opposed to no work in Saxony, and at wages higher than in Saxony or than those mentioned in the above report. Payroll records of the Amoskeag in 1880 tend to confirm this. The payroll record book of the "New Mills," fancy weaving section (under Augustus Canis, see below) are available. of the German workers, forty-seven worked the full twenty-four day pay period. The lowest daily wage was $\$ 0.84$, the highest $\$ 2.00$, and the average $\$ 1.36 .^{9}$ This is higher than the above report, and also generally higher than the wages reported by the U.S. Consuls for work in Saxony. From their reports, it is possible to calculate daily wages in saxony ranging between $\$ 0.51$ to $\$ 0.78$, and $\$ 0.79$ to $\$ 1.18$ depending on plant. 10 The Saxon weaver may or may not have been able to 
know the relative values of the wages between Manchester and Lawrence and Saxony, but he probably knew that steady work was available in the New England mills at that time.

That weavers emigrated from Saxony and southeastern Germany to Manchester and Lawrence can be verified. One source of verification, U.S. census data, is not particularly reliable in calculating province of origin. After the creation of the German Empire in 1871 the entry is often simply "Germany." Some information is available from the census data for 1870 and 1880. The information is rather incomplete, and Prussia could include in addition to Prussia proper its provinces of the Rhineland, Saxony-Anhalt, and silesia, anong others. Saxony-Anhalt, formerly part of Saxony, and silesia were industrialized regions in southeastern Germany. The census data is given in Table 5.3. 
TABLE 5.3

ORIGINS OF GERMAN IMMIGRANTS BY PROVINCE ${ }^{11}$

LAWRENCE

total Germans

Saxony

Prussia

174 (37.28)

154 (32.98)

Baden

$34(7.288)$

Bavaria

$30(6.638)$

1117

$473 \quad(42.348)$

$216(19.428)$

31 (2.86\%)

$44(3.93 \%)$

250

83

$62(24.7 \%)$

Source: U.S. Census, Population Tables, 1870 and 1880 for Lawrence. U.S. Census, Manuscript List, 1880 for Manchester.

The number is the identified Germans.

A further source of information is the obituaries in the Anzeiger und post. While there are limitations to the use of this data, it often gives the place of birth, approximate date of migration, and occupation. The data in Table 5.4 was calculated from obituaries appearing in the paper from 1901 to 1939 and 1942, only for those persons born in Germany and is combined for both cities. Former residents of Saxony and Saxony-Altenburg made up thirty-six percent of the total. Former silesians accounted for almost seventeen percent. Former natives of Bavaria and its Oberfranken region totaled fifteen percent. Thus, Germans from Saxony, silesia, Thuringia, and Bavaria plus those from Asch in Bohemia make up almost three-quarters of the total. The obituaries may 
overrepresent the former residents of these regions, but it is clear that Saxons and others from southeastern Germany were a substantial number of the total German immigrants in Manchester and Lawrence.

In addition it would appear that saxon immigrants to Manchester and Lawrence first arrived came at two distinct times. A review of 181 obituaries between 1889 and 1917 revealed that twenty-two percent (40 migrants) came between 1870 and 1879 , and thirty-five percent (63 persons) came between 1880-1884.12 This appears to agree with the reports of the U.S. Consuls.

The high concentration of Saxons in the two New England textile cities is remarkable considering the size of the Saxon migration during those decades. Reasons for emigration from Saxony were previously described. Despite those poor conditions Saxons represented, as shown by the consular Reports, about five percent of the total German emigration. From other scholars it is possible to estimate that 
TABLE 5.4

GERMAN BIRTHPLACES, MANCHESTER AND LAWRENCE RESIDENTS 13

PLACE
SAXONY
SAXONY-ALTENBURG
SILESIA
BAVARIA
OBERFRANKEN
GERMANY
THURINGIA
BOHEMIA (ASCH)
HESSE-NASSAU
ALSACE
AUSTRIA
BADEN/WÜRTTEMBERG
BRANDENBURG
PRUSSIA
RHINEIAND
BERLIN
POSNEN
DENMARK (SCHLESWIG)
SWITZERLAND
HANNOVER
POMERIANIA
LUXERMBURG
RUSSIA

TOTAL
NUMBER

354

26

179

146

17

117

42

30

24

24

18

18

12

10

9

8

8

5

5

4

3

1

1

1053
PERCENT

33.68

2.5

16.9

13.8

1.6

11.1

3.9

2.8

2.2

2.2

1.7

1.7

1.1

0.9

0.8

0.7

0.7

0.4

0.4

0.3

0.2

0.0

0.0

*GERMANY = listed as Germany, not given, or unclear. Percents do not add exactly to $100 \%$ due to rounding.

Source: Anzeiger und Post 1901-1939 and 1942, all years not complete.

Saxons may have been between five and nine percent of the total.14 saxons certainly showed a clear preference for New England industrial cities. 15

The Saxons who emigrated to Lawrence and Manchester came from the small towns and villages of the kingdom and not from the large cities. The birthplace of the immigrant was often included in the obituary in the Anzeiger und Post. Between 
1901 and 1942, among Saxons, there were 53 former residents from Glauchau alone. (See map in Appendix). Other, mostly small, towns reported as birth places include Meerane, Werdau, Reichenbach, Plauen, Zwickau, Auerbach, HohensteinErnstthal. Often the reports mention the region of the Vogtland which was particularly hard hit by competition from Alsatian mills. There was only one person born in Dresden. There are no indications, one way or the other, whether the individuals had moved from the villages to the cities of Dresden, Leipzig, or Chemnitz prior to emigration. Since the individuals were born in the villages, they had not migrated into saxony from other areas in Germany for work. Additionally, Asch in Bohemia was mentioned 21 times out of the 30 for Bohemia, and Hof in Bavaria was mentioned 73 times out of the total 163 for Bavaria. Silesia was mentioned 179 times. 16 These were all industrialized areas in southeastern Germany.

Individuals from those industrial areas in Germany did, in fact, transfer job skills from textile mills or machine shops to the mills in Manchester and Lawrence. How this occurred in each city must now be considered in detail.

Even before the the 1870s skilled German workers may have been attracted to the Amoskeag. For example, it has been commonly believed that gunsmiths were recruited from Germany to assist the Amoskeag in filling its order for rifled muskets during the civil war. It is known that there was a small number of Germans in Manchester in the 1860 s and 
that a number worked in the Amoskeag machine shop. 17 However, no definite proof of the claim has been uncovered in the available Amoskeag records that the workers were actually recruited in Germany. 18

clearly, however, the growth of gingham weaving at the Amoskeag owed much to German managers and workers. A key figure was Augustus Canis, born in Saxony in 1827. He immigrated to America in 1849, and settled in Manchester in 1854. His occupation in saxony is not known, but was likely textile related, since his occupation is listed in the 1860 Census as master mechanic, and in the 1866 Manchester Directory as an overseer. ${ }^{19}$ Canis worked in the Amoskeag for forty-one years, most of the time as overseer of gingham weaving, 20 which he is credited with establishing and expanding. He exercised important influence on German immigrant workers and managers. 21 In the Amoskeag Employee Room Register for the years 1871 to 1878 there are 69 Germans listed. Of these 61 listed their department as Fancy Weave Room, while 12 listed their department as "Canis," clearly identifying with their supervisor rather than their occupation.22 Additionally, in the payroll records of 1880 , seventy-four Germans are 1 isted among the over 400 employees of the Fancy Weave Department under Canis' supervision 23

overseer Canis had tremendous influence on other managers of Germanic origin in the Amoskeag. One protege was J. Adam Graf, born in 1849 in Asch, Bohemia, who migrated to Manchester in 1866, already with five years experience in 
weaving. He started in Mill Number 11 under Canis and after a year and a half on the job he was responsible for 200 looms. By 1876 he was a second hand and in 1899 he became overseer of the middle weave room of Mill Number 11 where he remained for the rest of his career. ${ }^{24}$ Graf became active in local Republican politics and served as Alderman and in the New Hampshire Legislature and Senate. He was also served on a number of city and business boards. 25

Canis influenced many others. Fred Artz, born in Germany, worked under Canis in 1899, became an overseer in 1920, and was the holder of several patents on mill machinery. 26 Louis Gersbacher, one of Canis' second hands in 1916, was born in Alsace and came to Manchester in 1871.27 Austrian born Henry Klaubert, another second hand, was hired by Canis shortly after his arrival in New Hampshire in 1891. 28 Likewise, German born Theodore Koehler, who in 1916 was in his twenty-third year as a second hand under $J$. Adam Graf, had been hired by Canis in 1876.29 overseer Andrew Netsch, a native of Austria had been hired by Canis in 1878.30 Several others who became managers under canis included Albert Artz (1882), Fred Simon (1886), and Robert Kointke (1892); and John Brunner (1886) employed by J. Adam Graf. 31

Given the different birthplaces of these men it is highly unlikely that Mr. Canis actively recruited them. Most likely they learned from relatives, probably employed under Canis, or Graf, to apply for positions in 
their departments. It is also likely that relatives vouched for them to their overseers. In several cases this can be documented. For instance, J. Adam Graf had a brother who had worked in the Amoskeag for several years. Albert Artz, who would become a second hand, started in 1882, and his brother Fred who would become an overseer started in 1881.32 on the payroll of the "Fancy Weaving Department" of Mill No. 5 in 1880 were four Hoffmanns, two Poehlmans, Englehardts, Vogts, and Gersbachers. 33 Tamara Hareven clearly demonstrates the family hiring and control system employed by the FrenchCanadians in the mills. The Amoskeag found this system to be in its interests. 34 There was a clear pattern of hiring German speakers for positions within these departments, and for developing or promoting them to management positions. In Lawrence, similar evidence of mentoring is not available, but it is known that individuals transferred skills from Germany to America. For instance, Fritz Poehlmann who emigrated to Lawrence in 1871 had been a weaver in Ernstthal, Saxony, and worked as a weaver in Lawrence. 35 Adolph Boehm who had been a weaver in his native silesia emigrated to Lawrence in 1872. He moved to Manchester and became a weaver and supervisor and then returned to Lawrence, where he was a section hand in one of the mills. By 1880 he had left the mills to open a wine and spirits store that grew into a locally famous restaurant and hall.36 Ernest August Dick, learned the weaving trade in his native Saxony. In 
1871 he emigrated to Lawrence and worked in the Washington Mills for the following ten years. He then opened a restaurant and lunch room on Essex street. The Dick family wolild become prominent in Lawrence and will be explored further below. The family exemplifies chain migration. In 1872 Ernest, a veteran of the Franco-Prussian War (1870), followed his parents to Lawrence. In 1874, Hugo, soon to be newspaper publisher, joined the family in Lawrence. 37 Oscar J. Koerner, Sr., began weaving in Germany at the age of twenty (in 1868), and he emigrated to Lawrence in 1872 . Shortly after arriving, he found employment in the Washington Mills as a weaver and later became a loomfixer. 38

In Germany during the third quarter of the century, many people moved from province to province in search of work (see above Chapter IV). Georg Laberle, an example of such a migrant, was born in württemberg in 1857, worked in the textile industry there, moved to Belgium for employment in wool spinning, and finally emigrated to America in 1879. Soon after his arrival in Lawrence he was a section hand in one of the mills supervising approximately 1,500 employees. Laberle became active in local politics and was elected to city offices between 1886 and 1889.39

In addition to the individuals whose histories are presented above, many others arrived in Manchester and Lawrence with job skills learned in German textile mills. These skills enabled them to obtain positions in the textile mills of the two cities. A number of the German immigrants 
obtained jobs in the mills at the higher skill levels, and some were promoted into supervisory positions. 40 Augustus Canis, J. Adam Graf, and Oscar Koerner are examples of those who became supervisors and made careers in the mills. Adolph Boehm and Ernest August Dick are examples of others who left the mills after a number of years to start businesses. They were at a high enough level in the mills to be able to save funds to start businesses.

In addition to arriving with transferable job skills, Germans seemed to have occupied the higher skill level jobs in the mills, out of proportion to the number of Germans working in the mills. In the Amoskeag in 1880 of approximately 80 identifiable German employees, three were supervisors, 45 held the highest skilled labor positions, and nine had unspecified occupations in the mill. Eleven others were in the skilled crafts such as carpenter, painter, plumber, and baker. In 1885 there were seven German overseers, 68 in skilled occupations, and 108 whose occupations were not specified. In 1895 there were six supervisors, 124 skilled laborers, 68 "operatives," a vague category indicating unskilled or semi-skilled jobs, and 117 1isted as in "the mill," which probably also means unskilled. 41 Even taking the lower two categories together as unskilled, forty-percent of the Germans in the mills held skilled positions. Hareven shows the relationships of ethnic groups to supervisory positions. By far the largest number were Americans with 88 male and 22 female supervisors (total Americans, 1,352). 
Next were the Irish with 11 male supervisors (total Irish, 1,350), the Germans 8 male supervisors (total Germans, 498), and scotch 5 male supervisors (total Scotch, 341). There were four male English supervisors out of a total of 221 workers born in England; and four male supervisors among a total of 4,376 French-Canadian workers. 42

German women worked in the mills for short periods and most likely at unskilled positions. The Marriage Records for Manchester from 1885-1936 were cross checked with manuscript census data and directories. From this data two things appeared. Unmarried German women in their late teens or early twenties sometimes worked in the mills as "operatives" and may have continued to work for one or two years after marriage. Most married German women are listed as "housewife."43 Entering the mills with no experience and leaving after a few years, the young women were likely to be in unskilled positions.

Similar occupational characteristics are observed in Lawrence. In 1875, among the Germans in the mills, there were 18 in skilled occupations, two overseers, 51 whose jobs were unspecified, six operatives and three unskilled mill workers. In 1881 the skill levels had not improved much. There were 20 skilled laborers and five supervisors, 67 with unspecified occupations, and 68 listed as operatives. By 1885, however, more Germans had moved into skilled positions; with four German supervisors, 70 in skilled positions, 26 with unspecified positions, 68 listed as operatives, and four 
with clearly identifiable unskilled jobs. 44 That so many Germans held higher level positions in 1885 indicates that those arriving between 1881 and 1884 brought transferable skills.

Although dominated by textiles, Manchester and Lawrence were more than just the mills themselves. Workers and supervisors needed groceries, clothing, shoes, fuel, and other goods and services in their daily lives. Businesses to fill these needs developed, and businesses operated by Germans serving Germans opened in both cities. In addition to retail establishments and the building trades, Germans operated companies producing cigars, beer, sausages, and specialty textiles.

The Olzendam Hosiery Company operated independently of the Amoskeag and became the leading German owned specialty textile company in Manchester. The company was established in South Manchester by Abraham Olzendam, who was born in 1821 in Barmen, Rheinprovinz. He had learned the trade of dying there and in 1848 he emigrated to the United States working in different factories in Massachusetts. In 1858 he moved to Manchester and worked as a dyer and color mixer in the Manchester Mills until 1862, when he established his own hosiery company. 45 In 1888 he purchased a mill in south Manchester, which became well known, and became one of the largest such companies in the state. His businesses successes led him to public activities and acceptance in the city, since he served as representative of the Eighth Ward 
between 1873 and 1874 , and he served in the New Hampshire Senate. Additionally, he was a trustee of the citizens Savings Bank. Upon his death in 1896, it was reported that Mr. Olzendam was a member of "many American lodges" and was a supportive of many German causes, especially the German school. 46 In 1905 the company failed and its building was taken over by the Amoskeag Company. 47 There is nothing to show Olzendam's involvement in the German clubs of the city, and it was reported that he had joined American lodges indicating upward mobility and assimilation. Except for the German School, no specific information about the support of many German causes was provided. Olzendam, despite his success and apparent assimilation, did support the efforts to teach German.

As noted, Manchester Germans tended to settle on the West Side, along the Merrimack River, and up to its small tributary, the Piscataquog. (See map in Appendix) This district was never exclusively German, since a number of French-Canadians and Irish also lived there. However, it took on a German flavor when many businesses operated by Germans to serve German clients developed there. By 1875 several groceries, produce stores, and approximately four saloons and or wine and liquor stores, and one billiard room and saloon were established by Germans. The custer family was especially successful. Emil custer was a homeopathic physician, his wife was a pianoforte teacher, and his 
daughter, Lina, taught pianoforte and German. By 1880 the number of fruit companies had grown to three, a sausage-maker was in town, there were five saloons, and a billiard room. 48

By 1885 Germans could find entertainment in eight saloons, three billiard rooms, and one bowling alley, in addition to the vereine which will be described below. Germans operated two bottling plants for soft drinks. There were now several more grocery stores and butcher shops. Ernst Graupner had established himself as a cigar dealer and manufacturer. Fred steiner operated a multi-faceted service business. He was simultaneously a Justice of the Peace, an insurance agent, the local passenger agent of the HamburgAmerica, the Amsterdam, Red Star, and American Lines, a preparer of drafts to "all places," and a parcel express agent. 49

Ten years later German commerce in Manchester continued to thrive. There was now a German-language newspaper, which will be discussed in more detail later. Providing many of the same services as Fred Steiner was Notary Public Hermann Rodelsperger, who performed many of non-church marriages of Germans in Manchester. If one were not satisfied with the services of these two gentlemen, one could select from two other Justices of the Peace and one attorney. William schunland, whose brothers operated the same business in Lawrence, manufactured sausages. The company would remain in family control for several generations and the brand name continues to the present. If one's palate was not satisfied, 
there were two additional sausage manufacturers. Gustave Kretschmer had established a bakery (one of two in the German district) which was to last until the 1950s. Germans could fulfill their needs by buying from the German owners of two coal and wood dealers, several grocery stores, butcher shops, two florists, several bottlers, several dressmakers, a variety store, two cigar manufacturers and dealers, several clothing and shoe stores, and a number of tailors. Medical services were provided by two physicians, a dentist, and an apothecary. They could enjoy their beer in eight different saloons. There were plenty of German carpenters, painters, tinsmiths, and other tradesmen to build or repair a house. 50

In Lawrence in addition to the residential area, in "Hallsville" and Prospect Hill, Germans located a number of their shops in the city's east of the Common on Essex street and some streets parallel to Essex. The locals sometimes referred to the German residential and commercial zone as "Dutch Gap." (See map in Appendix).

In 1875 a small number of German shops, business, and saloons existed in Lawrence. Ernest Dick began operating his well known contracting company, which would later build the Armory huilding, the Emerson Manufacturing Co. and the Buxton Block among other projects. Unsurprisingly, he built the new Turnhalle, but the company also won the contract for the Hibernia Hall. There were three German owned grocery stores, three bakeries, a number of tailors and a clothing shop, several shoe shops and shoemakers. Henry Schunland began the 
sausage making business. There was a German physician and German music and language teachers. 51

With more immigrants arriving, Lawrence's German community continued to grow and expand. Five years later otto schindler opened his hotel. Frederick Matthes sold beer in his "Matthes Hall," in which a number of Vereine got their start. Richard, Henry, and William Schonland, the latter who was to move to Manchester, worked in their father's sausage manufacturing company. Henry Vogel and Henry Behrmann operated a shoe manufacturing company. A variety store catering to Germans had opened, and several saloons thrived. 52

By 1885 German operated companies had expanded again. Hugo Dick ran a book and periodical shop and published a German-language newspaper. August Hoffmann worked at the brewery, and brothers Carl and william operated two separate saloons. August steigler owned a tobacco store on Essex street. John Wurzbacher started his long lasting stove, range and furnace company. August Yuggebauer started his provision company. There were several new saloons, a few more bakeries and confectionery shops, and two additional cigar manufacturers, most likely one- to three-employee shops. 53

Germans opened more businesses in the next five years. The Kress Brothers began their carriage making company and their coal and wood shops. Adolph Boehm opened his liquor store and cafe at 18 Essex street. Several physicians and 
apothecary shops tended to illnesses. Germans provided insurance, passenger tickets, and legal services. The number of carpenters, painters, tinsmiths, and plumbers had grown substantially, and one could rely on German craftsmen. The Steigler company upholstered, made, and sold furniture. There were additional provisions stores, groceries, and clothing stores. 54

By 1895 German enterprise continued to flourish. Ernest Dick now had a successful construction company and a planing mill. His brother Hugo continued publishing a newspaper. Julius Emmert had opened his funeral parlor and temple, providing services for many years: and the family continues the service today, just as the Breen family was to serve the Irish. Boehm's cafe and liquor shop had expanded to 78 and 82 Essex Street. Lawrence's Germans could buy their provisions and groceries from seventeen different shops, plus several butchers; their clothing from more than a dozen tailors, dressmakers, and clothing stores; and their watches from four different jewelers. If they became ill they could chose from two German physicians, go to the German dentist, and buy medicine from three different apothecaries. Henry Schbnland still manufactured sausages, and son Henry had opened a provisions and grocery store. There were at least five German cigar manufacturers. 55 Tobacconist August Steigler, who now had shops at 171 and 269 Essex street, was also the Treasurer of the Cold Spring Brewery. The brewery employed Adolph Vorholz as brewmaster, Charles Scholstein as 
superintendent, and Adam Burger and John and Joseph Praetz as brewers. In 1904 it was capable of producing 30,000 barrels of beer which it shipped to several New England states. Its local competitor was the Diamond Spring Brewery, operated by the Holihan Brothers. 56

A German owned textile company also operated in the city. In 1886, F. Stanhope Phillips and George Kunhardt, both of New York, purchased the Lawrence Woolen Mill. Kunhardt moved to Lawrence to operate the company and by 1895 he was in sole control of the newly renamed George E. Kunhardt Company, which specialized in worsted woolens. By 1920 it had 288 looms, 14,000 spindles and 900 employees. Kunhardt became wealthy from the mill and noved to an estate in North Andover. The company went bankrupt in the 1930s.57 Kunhardt, who was on the board of the Essex Savings Bank, was not on the board of the Cold spring Brewery, whose board members tended to be the smaller German entrepreneurs of the city. There are no records of his involvement in German associations.

Despite the small number of Germans in the relatively small cities of Manchester and Lawrence, Germans owned and operated shops and services which served the German clientele as well as others. In this respect the textile cities were similar to the larger Midwestern cities, with their large German-American populations. The Germans, not unlike the Irish and later immigrant groups, operated many stores related to basic necessities such as food and clothing. They 
also seemed to gravitate to certain enterprises and trades such as butcher shops, sausage making, saloons, and carpentry. The districts with these businesses took on a German feeling which were recognized and remembered well into the twentieth century.

The saying that, "wherever three Germans congregated in the United States, one opened a saloon so that the other two might have a place for their quarrels, "58 could be broadened to include Vereine. Germans in Manchester and Lawrence opened saloons where one could go for for drink, entertainment, meeting and exchanging news, job openings or local gossip, or to quarrel. They also founded clubs, or Vereine, which provided a more permanent drinking Lokal, more elaborate and consistent entertainment, a friendly meeting place with fellow Germans of like interests, and probably a place to quarrel about all of the foregoing. The German immigrants in Manchester and Lawrence established Vereine soon after they settled and when they were still few in number.

German settlers usually founded a Turnverein almost as soon as they settled. Manchester was no exception. In 1870 six German men got together to found the Manchester Turn Verein, undoubtedly with more hope for success than immediate means of accomplishing it. They received some assistance from the neighboring Turners in Lawrence. A plot of land was leased for a yearly fee of $\$ 5.00$, and a gymnastics building was constructed for $\$ 20.00$. In 1870 the "Manchester Turn 
Verein and Gymnastic school" received a charter from the state of New Hampshire. The local Turners quickly outgrew its buildings and constructed larger ones in 1873 and 1875 . The Turnhalle was the largest of several German halls in West Manchester and the site of musicals, dances, lectures and political rallies for the German community 59

Many German-Americans thought it important that their children speak the German language. Consequently, among the first organizations established was a German school. In 1875 a group of German-American citizens formed the German School (Die Deutsche Schule) for the purpose of teaching the language to the German children of Manchester. By 1876 the school was offering regular classes. In 1884 the Schulverein had constructed a very substantial school house on Ferry street in west Manchester. At that time, approximately 50 children attended German classes and by 1891 attendance had grown to 100. The members of the schulverein pledged to teach the German mother tongue as long as there were GermanAmerican citizens in Manchester. 60

A lodge of the fraternal and benefit "German order of the Harugari"61 was founded in Manchester in 1873. Five Germans, with the assistance of the "Schiller Lodge" in Lawrence founded the local "Barbarossa Lodge." These five were able to convince twenty-three others to join by 1874 . Several years later the Barbarossa Lodge had constructed a Harugari-Halle for Manchester.

A particularly infl.... :ial, and coincidentally long 
lasting, mutual aid club was the Arbeiter KrankenUnterstützungs Verein. Formed in January 1893 by nineteen German workers in the Manchester Turnhalle, by February its frugal members had saved $\$ 27.00$. Already in 1884 members made monthly payments of twenty-five cents into the death benefit fund. By 1892 the Verein had grown to 205 members. In 1898 the it established its "singing section" for the entertainment of its members in their new hall which had been completed in 1897. The $A-K-U-V$, as it came to be called, also scheduled dances, social activities, and lectures. Its membership, as would be expected, was from the working class, but a number from the lower middle class joined. Since the Turnverein had a reputation of being the club for "free thinkers," Catholic Germans seemed much more likely to join the $\mathrm{A}-\mathrm{K}-\mathrm{U}-\mathrm{V} .62$

Wherever Germans lived they formed musical societies and bands. If the A-K-U-V "singing section" was a little late in forming--the tradition was maintained in 1883 when sixteen young German singers founded the Manchester Mynnerchor. In 1890 the Munnerchor began the construction of its rather large, three story Halle, rounding out the major German halls in Manchester. Other musically inclined Germans in Manchester founded the Beethoven MHnnerchor in 1885 and constructed their own hall. 63

Sometime in the 1890's a Bavarian club (BayernvereinsManchester) was founded. It would represent the first Landsmannschaften, or club for persons from a specific region 
of Germany. In 1897 there is a report of the club sponsoring a masked ball at which about 57 members attended. Since it was held at the Harugari Hall, this would seem to show that the club did not build its own hall. There is little other information available about this club, which appears to have been a relatively minor player on the verein scene in Manchester. 64

Germans in Manchester, much like Germans in other cities, founded Vereine soon after they settled in. The Vereine helped foster a sense of unity among the Germans and were a means of keeping a German culture alive. They were places in which entertainment in the form of gymnastics, bands, dances, and musical evenings, and lectures could be held. Their halls became convenient meeting places to support German candidates for local office or places to rally for particular causes, such as protests against Prohibition.

The few Germans living in Lawrence in the mid-nineteenth century lamented the lack of a Turnverein. After a number of false starts, seventeen of them were able to form the Lawrence Turnverein in April 1866. In 1867 there were already fifty members of the Verein, and they had erected a summer-exercise field. In 1868 when the Turnverein erected a hall which was enlarged in 1881 and again in 1891. The Lawrence Turnverein hosted the Neu-England-Bezirks-Turnfest, or New England regional competition, on July 4, 1892. A fire completely destroyed the Turnhalle in 1894, but the club immediately constructed a new building costing over twenty- 
eight thousand dollars, a hefty sum in those days. Fritz Knorr, the Turnlehrer or gymnastics teacher, hired in 1893 was still instructing his young gymnasts in 1916. The Lawrence Turners were one of the more powerful and wealthy of the German Vereine in the city. 65

The fraternal and benefit aid society of schillex Loge of the Deutschen ordens der Harugari organized next. As early as 1864 a group had organized a small chapter in Lawrence. By 1869 the members purchased a small house, and in 1890 the Lodge purchased Schindler's Hotel for its lodge hall. 66

German singing voices in Lawrence were able to organize sooner than their brothers in Manchester. In 1874, Der Gesangverein Lyra organized in Matthes Hall, a function room of a German saloon. Desiring its own meeting hall the society purchased a cottage by 1886 and in 1889 the society had a city charter. Just before the turn of the century the Lyra constructed a large musical and meeting hall. Apparently, only one singing society would not do for the Germans, and in 1882 the Lyra was joined by the Gesangverein Glocke. In 1891 the Glocke built its own hall, which it enlarged in 1899.67

The German Co-operative Grocery Association (Der Deutsche Konsumverein) formed in 1874 to give newly settled Germans, whose English was not strong, a place to shop. Established as a voluntary association, it purchased goods for resale to fellow countrymen at reasonable prices. Within 
a few years the association had a profitable store. 68

Germans in Lawrence also attempted to preserve the German language. Those who founded the Allgemeiner Deutscher Schulverein believed that "one of the noblest goods that the Germans brought to this land is their Mother Tongue," and they should "do everything in their power to bequeath it to their children and their children's children, as the poet so true and heartfelt said,' the spirit of the father lives forever in them." 69 with this spirit in mind in 1873, a group of Germans set to work to form a school. By 1875 the twenty-four members of the Verein were successful in founding the deutsche schule. The new school opened in the Turnhalle with seventy-four students. For the first several years the lessons moved around. In 1876-1877 classes were held in a room of Matthes-Halle, from 1878-79 in Schindler's Hotel, and then once again in the Turnhalle. In 1884 children could take their lessons in the new school house. 70

Between 1870 and 1900 , a number of German mutual aid societies were formed. These included an Arbeiter Kranken Kasse, an Arbeiter-Krankenunterstützungsverein, an Allgemeiner Deutsche Unterstützungsverein, and a number of sterb-Kasse and Kranken-Kasse the major German Vereine. The first citywide German committee was the Deutsches Freibett-Komitee. Payments into its fund provided for a "free bed" at the Lawrence General Hospital. The committee, organized in 1892, continued to collect funds and pay for "free beds" until at least 1941.71 
Societies for Germans from particular provinces (Landsmannschaften) also formed in Lawrence. The most successful and long lasting was the Bayersicher Lese-und Fortschrittsverein or Bavarian Reading and progressive Society founded by thirty-four Bavarians in 1890. Like other new societies it started out in Matthes Hall, but moved to the restaurant of $\mathrm{H}$. Sch⿰丿⿱丄𠃍). Its members decided that the club needed a more appropriate meeting facility and constructed a hall in 1896. Similar, to the other societies a health insurance plan or Krankenunterstützungskasse was established for members in 1882. The Alsatian-sick Benefit Society was founded in 1899 specifically for individuals from Alsace. It also scheduled social activities for its members. 72

One other Verein deserves a brief mention. The Concordia Schützenverein, or marksmanship club, was founded in 1886. Shooting clubs were popular in Germany and there was usually one wherever Germans settled. It built a club house and shooting range on the top of Prospect Hill. As more and more houses were built in the neighborhood, shooting diminished. 73

The Germans in Lawrence, as the Germans in Manchester, and elsewhere in America, formed Vereine almost as soon as they arrived in the cities. The larger number of Germans in Lawrence supported more and a greater variety of Vereine, than the Germans in Manchester supported. Also, Lawrence's Germans formed clubs earlier than those in Manchester. 
However, in both cities most clubs were founded between 1870 and 1900, the period of immigration. The German immigrants in both cities found no established Vereinsleben when they arrived. They were free to establish clubs without conflicts between "new" and "old" Germans.

The Vereine in Lawrence and Manchester fall into the same general categories as German clubs elsewhere. There was the Turnverein, a number of singing societies, a number of fraternal and social clubs, several mutual aid clubs, and several Landsmannschaften. The Vereine played a key roll in establishing and maintaining Deutschtum in both cities and will be explored further below. It is also apparent that the leadership of the clubs remained in the same hands or families for a number of years and this will also be explored below. The membership of the clubs, except for the "worker" or Socialist clubs, was comprised mainly of the skilled labor and entrepreneurial class.

Germans in Lawrence and Manchester also established their native churches soon after arriving in both cities. The church as an ethnic institution has been clearly understood. According to H. Richard Niebuhr for the average immigrant "neither Goethe nor Nietzsche was more than a name to him, but Luther and the German Bible or the crucifix and the mass he knew."74 Niebuhr also concludes that "perhaps religion is as much responsible for ethnic character as the latter is responsible for the faith."75 This helps explain the immigrants' immediate desire to build a church. For the 
ethnic group the preservation of the religion was the preservation of language, but according to Niebuhr all religions would accommodate on language to maintain the denomination 76 In fact the need to accommodate and conform to the American situation is the case for all denominations. 77 The well documented ethnic conflicts in the Catholic church were really about the formation of "othnic" Catholic churches or an American Catholic Church. 78

The German churches in both cities tended to reflect the religious beliefs Germans brought with them to America. For Catholics, German parishes formed in both cities. There were synagogues. Lawrence had several, at least one of which was predominantly German, while the only one in Manchester was Russian. Typical of German immigrant,s a number of "free" or new denominations existed. Uncharacteristically, Lutheranism was not strong among the German of both cities. Although Manchester had one Lutheran Church, Lawrence did not have one until the 1930s. The German Presbyterian denomination became the most important in both cities in terms of size, prestige of its members, and influence in the German-American communities.

The predominance of the Presbyterian churches in both cities is something of a puzzle. Lutheranism and Catholicism are generally viewed as the strongest denominations within Germany, although Reformed denominations existed also. Likewise, Lutheranism and Catholicism characterized the beliefs of many of the German immigrants to the United 
States. Sydney Ahlstrom, in A Religious History of the American People traces the German Reformed Church to Zwingli in Zürich. 79 Andrew Drummond, in German protestantism since Luther concentrates more on the Calvinist or Reformed religion in Germany. 80 He notes that a Calvinist had been appointed court chaplain in Dresden. 81 Furthermore, some of the smaller states such as Hesse, Nassau, Hesse-Kassel apparently adopted Calvinism. Some pockets of Calvinism existed in the Anhalt and Liegnitz districts of saxony and Brig in Silesia. Drummond considers the Reformed church, despite the Court chaplains, to have been negligible in Saxony 82

In the eighteenth century, the German Reformed church came with emigrants to the Middle Colonies. In 1746, Michael Schlatter, a Swiss calvinist arrived in the United states to revive the German Reformed churches in Pennsylvania. In this effort he had the close cooperation of the Dutch synods of the Reformed Church. 83 In fact, according to Niebuhr, "the German Reformed Church's...religious and doctrinal affiliations were with the Dutch Reformed church and with Scotch Presbyterians....[and] it had derived its chief financial support for many years from the national church of the Netherlands." 84 schlatter's efforts to revive the German Reformed Church met with the most success in Pennsylvania and Virginia. One scholar sees similarities between certain aspects of the Reformed Church, and the Pennsylvania Dutch, and Presbyterianism especially with regard to the election of 
deacons, elders, and church treasurers and a number of other methods for making decisions in the church. 85 The strength of the German Presbyterian churches in Manchester and Lawrence cannot be fully explained by the presence of the Reformed church in the eighteenth century in the Middle Colonies.

No definite proof has been found of a link between the Reformed Church in Germany and the German Presbyterian Churches in Manchester and Lawrence. Moreover, the "Records of the Session" of the German Presbyterian Church in Manchester were kept in English and reviewed by the Englishlanguage Boston Synod. 86 However, since the congregations were formed so soon after settlement, 1875 in Lawrence and 1882 in Manchester, some connection must have been present. The Presbyterian churches became the most dominant in the cities as the result of several factors. Both churches were fortunate to have had influential, German-speaking pastors, with long tenures between 1900 and the 1930s, which added stability. Also, both churches appeared willing to join with the Vereinsdeutschen, especially for charitable activities in both cities. German Catholics joined on a few occasions, but were normally reluctant to do so. Additionally, the Lawrence Presbyterian church financially supported the German School. Furthermore, prominent German businessmen of both cities tended to belong to the Presbyterian Church. The Anzeiger und post included "church notices" for all denominations, but the Presbyterian news 
seemed to predominate. The editors were Presbyterian and they may have favored their own denomination, but there is little surviving information from the other denominations, so the impression could be skewed. However, all evidence points to the fact that the German Presbyterian Churches were the most influential denominations in both cities.

The history of the German Presbyterian Church of Lawrence states that in 1872 "[thirty-four] deutsch-ev. Leute" rented a chapel in which a Pastor schwartz from Boston preached and formed a "deutsch-ev Kirchenverein." 87 Unfortunately, the account provided no specific definition of evangelisch-reformiert which might provide positive proof of the transmigration of a reformed church. From this small group die Deutsche Presbyterianer Kirche was formed. In 1875 land was purchased on East Haverhill street and a church was built. During the first years a Frauen-Verein (women's club) and a young people's society were founded. By 1880 , the church had grown to 103, and by 1900 it had 300 new members. Therefore a new, larger church was constructed. From 1872 to 1927 Frederick Vietor was the leader of the church school. Richard Lange, installed as pastor in 1906, served until 1939.88 The long tenure of the pastor and the sunday school teacher gave the church a remarkable continuity.

The establishment of Die Erste deutsche PresbyterianerKirche or First (German) Presbyterian Church in Manchester came a few years after the establishment of the denomination 
in Lawrence. According to church records and publications, in "about 1874 the gospel was first preached in German." 89 The date of the services so soon after the arrival of the immigrants would also indicate the transferral of the denomination from Germany. Until 1881 sermons were preached by itinerant ministers, including Rev. Schwartz of Boston. Pastor Hager of Lawrence also preached in Manchester and was instrumental in establishing the Manchester church. In 1881, a number of Germans met at the home of Augustus Canis, the supervisor of the gingham mills, and considered the organization of a "religious society." In 1882 the members (between 24 and 48) "were organized by the Boston Presbytery into a Presbyterian Church." By 1885 the Church building was dedicated. Also various church societies soon formed. Swiss-born John Kamm was installed in 1900 as pastor and he served until 1935.90 Kamm, who was respected in both the church and the city, provided stability for the denomination. Normally, soon after enough German Catholics arrived in an area they demanded a German parish or German-speaking priests. In Lawrence the Germans set up a Catholic Parish, while in Manchester, the bishop connived to get a Germanspeaking parish as a way to get a college.

In 1885, the German Catholics of Lawrence held their first services with a visiting priest from Boston. 91 soon thereafter, approximately fifty Catholics established a group to raise money for a parish, and in 1887, Archbishop Williams of Boston appointed a German speaking priest for the German 
Catholics in Lawrence. 92 In 1888, the new church building of the Assumption of the Blessed Virgin Mary, (Mariahimmelfahrt) was dedicated.93 The wooden building had (and has) a distinctive southern German style. Due to the illness of the first pastor, Archbishop Williams asked Father O'Reilly, the Augustinian pastor of st. Mary's church in Lawrence, to locate a German speaking priest. Fr. O'Reilly succeeded, and the Augustinians provided pastors until 1984.94 In 1889 the Church opened a school in the basement. 95 By 1908, there were approximately 400 members of the parish. 96

Whatever the disputes between Irish and German Catholics and clerics elsewhere, there was a willingness of the Archbishop and priests in Massachusetts to establish a German parishes. The role of the Bishop of Manchester in forming a German parish was even more unusual.

The establishment of a German Catholic parish in Manchester came about not as a result Germans requesting one, but from the desires of Bishop Denis Bradley, of the newly formed (1884) diocese of Manchester for a college. In 1886, the bishop wrote to a friend Father John Edwards:

I want a college in my diocese and would like to have it urder the control of true Benedictines. Now there is a suburb of this city where I have some Germans who are being lost to the Faith because of the want of a priest of their own nationality to minister to them; there are in the same place some English speaking Catholics.

Should the fathers be unwilling to accept

the care of these few souls about five hundred--I would be satigfied to have the services of one sunday. 9 
A threatened loss of faith by German Catholics was calculated to bring a positive response. The Bishop selected the Benedictine order because it was mainly German-speaking. Next, the Bishop wrote to Abbot James Zillox, at st. Mary's Abbey in Newark, New Jersey, that he "intended to give a portion of the city to you," and the "people under your charge would be English and German speaking and all the Germans wherever found in the city."98 The Benedictines were somewhat reluctant to found a college in Manchester, and decided instead to establish a parish for the German-speaking Catholics of the city, sending Father sylvester Joerg as the first pastor. Appropriately, the parish was named for st. Raphael the German patron saint of emigrants. From the start the new parish was bilingual. However, Father Joerg soon encountered difficulties in the form of a more diverse congregation than he had contemplated and a shortage of funds for the parish. In April 1888, he wrote Abbot Praengle, in

New Jersey, that his congregation included:

approximately 20-30 families who are German, all others are from Ireland. Also, of the Frenchmen, many are willing to come and the bishop has permitted me to rent seats to anyone.... The regulation in this diocese is that people may attend chuggh, respectively, hear Mass where ever they wish. 99

Such difficulties made the Benedictines even more reluctant to establish a college. Bishop Bradley, frustrated by the delays, wrote Abbot Praengle that he was apprehensive of "the French [Canadians] making a move in the direction of a college in the event of a delay."100 This worked, and the 
Benedictines commenced building st. Anselm College. Continued financial difficulties led the Abbot to write the Bishop requesting the addition of the "French people," to the parish and expanding the boundaries of the parish to generate more revenue. 101

Despite these difficulties, Father Joerg decided to build a combination church and school, and the corner stone was laid in 1888. The school, under the direction of the Benedictine Sisters from New Jersey, opened in 1889 with 124 students attending. Uritil 1942 the Benedictines sent priests who were German or German-Americans. They continue to staff the parish and st. Anselm college to the present.102 The number of Germans in the Manchester parish was relatively small. St. Raphael's received far less mention in the Anzeiger und post than did Mariahimmelfahrt in Lawrence. A review of marriage and death records of the church and marriage records of the city of Manchester indicates a predominance of immigrants from Hungary and Poland in the parish. 103

Before continuing, we should note the presence of several smaller denominations in the German community of Lawrence and Manchester. For example, one of the earliest churches founded in Lawrence was the German-Methodist church. Founded in 1878 with a congregation of nineteen, it had outgrown one building and had over 250 members in 1908. The church sponsored a sick benefit society and the usual women's and youth societies. Hermann Kertz, superintendent of the 
Sunday school, served from 1881 to 1908.104 The Church was active until at least the 1950 s but was never as influential as the Presbyterian Church. A smaller evangelical denomination founded in Manchester was the Erste neue deutsche-Kirche, or First German New Church. Its societies were active and often listed in both the German and English newspapers, but its size cannot be estimated. The church lasted at least until the 1940s. 105

Lutheranism, often associated with northern Germans, 106 had very little hold on the Germans of Manchester and Lawrence. In Manchester, a German Evangelical Lutheran Emanuel Church was founded, but only in 1896. This church had a number of societies for its male, female, and young members. Its services and events were listed in the German and English newspapers of Manchester. Unfortunately little else is known about it. 107 In Lawrence, there was no Lutheran Church until 1930 when a mission church was established. Attempts to found a Lutheran Church had only begun in 1925.108 For whatever reason Germans in Lawrence were not disposed toward the Lutheran denomination. That no other church existed can be shown from the fact that the Anzeiger und post contained neither church news nor obituaries for burials from a German Lutheran Church in Lawrence prior to 1930 . The relative unimportance of the Lutheran denomination among German immigrants is highly unusual.

From a discussion of churches, the institution which 
represented the ethnic culture and attempted to preserve German language and customs, we will turn to the other institution in a German community which often represented it, spoke for it, and attempted to preserve it--the Germanlanguage newspaper.

Nearly all German-American communities sooner or later founded one or more German newspapers. Manchester and Lawrence were no different in this respect, with the former having one paper and the latter approximately three for short periods. From 1883 to 1942 Germans of the two cities read the weekly Anzeiger und Post, formed by the merger of the Lawrencer Anzeiger and the Manchester Post. 109 That a German-language newspaper could have survived so long in cities with so few Germans is remarkable. Almost from its inception, the newspaper billed itself as the "leading German newspaper in New England," reaching "practically every German home in Lawrence, Manchester, clinton, Fitchburg, and Taunton Mass, and other New England cities."110 It is also unique that long runs of this paper are still available. In the absence of diaries and letters, the Anzeiger und Post provides much of the information for this study. Of course, this information reflects the views of the publishers, who were among the elite of the community. However, it is also an important source of information on the Germans of Manchester and Lawrence and northern New England. The paper faithfully reported the events of the Vereinsleben in the cities from which important information about Deutschtum can 
be gleaned. Obituaries, wedding anniversaries, business openings and so forth provided personal information about many of the German-American residents of the cities. The publishers often muted their views and beliefs. Often little editorial content was contained in the paper when important national or international events happened. This should not be unexpected as Carl Wittke, the foremost historian of the German-language Press in the United States concludes:

The first responsibility of an editor... was to make his paper financially successful. He was not employed to lead crusades, or for that matter, to develop good relations between the United States and Germany..... His job was to edit an American newspaper in the German language and make it pay .... The German-language press reported the news from Germany because its readers were interested in what was happening to friends and relatives abroad. Editors frequently discoursed on the cultural achievements of the German people, but there were relatively few discussions of matters of haute politique in the German-American press. III

James Berquist adds the following:

German newspapers which hoped for general circulation in the community also learned to avoid divisiveness; like their small-town English language counterparts, they knew that taking sides often meant sacrificing subscribers. Thus the German-language press often reflected a bland and optimistic view of the community which deliberately hid its internal conflicts. 112

Since the editors and publisher of the Anzeiger und post were also its co-owners, their financial well being was certainly at stake. Their views may or may not have reflected those of the community at large on all issues. Certainly they were not radical, but they were progressive on 
a number of issues. To have been radical would have meant the loss of subscriptions and revenues. They reprinted material from other German-language newspapers, which through its selection could show their views, though in a more indirect way.

The important role of a German-language newspaper should not be underestimated. In 1882, Hermann Rastner, editor of the Chicago Illinois staatszeitung, "linked the newspaper with the the church and school as the 'backbone' of German culture in the United states, and stressed in particular the role of the press in creating 'German-American life,' thus giving the German immigrant a feeling of pride in the cultural achievements of his people."113 No less a luminary than Carl Schurz believed that:

its major purpose was to explain America to those who could not yet read English; to keep the German element informed of the intellectual progress of Germany: and to promote understanding and cooperation among the Germans in the United states. He also stressed a fourth obligation of the German-language press, namely to teach German immigrants how hospitable and unprejudiced the United States had been toward the foreign-born, and how it has welcomed the stranger with

open-handed generosity. 114

It will be shown that from time to time the Anzeiger und post fulfilled several of these functions.

From the Anzeiger und Post many aspects of the Vereinsleben and the conditions of Deutschtum in Manchester and Lawrence can be learned. This is quite natural, according to wittke: 
Every German-language paper reported in detail the many social, musical, and dramatic activities of their German community, for the survival of the German press depended upon the extent to which German-Americans retained their interest in the social and cultural life of their people. Conversely, the successes of the various undertakings of the German societies depended largely on the publicity which they received in the German press. Publishers and editors of German-language newspapers were leaders in such organizations, and each needed the other's support to survive. The German press pleaded with its readers to cherish the German language, and bequeath them to their children, lest the country sink into a 'Puritanical swamp.' German societies were admonished to end their chronic bickering and to present an united front to the enemies of German culture and personal liberty. 115

The Anzeiger und Post was no different than the other papers on these matters. Its publishers were active in local organizations. Also, like its counterparts, the Anzeiger und Post promoted "German Day" and similar celebrations. It published personal notices of weddings, parties, funerals, and anniversaries, which were of interest to its readers, and which prove to be, along with the Verein news, valuable sources of information. Finally, and again typically, the Anzeiger und post constantly campaigned for the maintenance of the German language.

The early history of the German-American press in Manchester and Lawrence is only partially available. In 1881 to 1882 a German weekly "Lawrencia" existed. Its failure left the local German readers without a paper until 1883 when Hugo Dick founded the Lawrencer Anzeiger. Dick was born in Glauchau, Saxony, in 1856 and apparently learned the 
book printing or selling business there as a youth. In 1874 he emigrated to Lawrence at the age of eighteen to join his father and mother, Frederich August and Ernestine, who had arrived in 1871. His brother Ernest, who founded the building business, had arrived in 1872. In 1875 Hugo Dick was employed in the Washington Mills, where his father also worked. By 1885, he was publishing a newspaper and operating a book and periodical store a short distance from his father's saloon and restaurant on Essex street. 116 In 1890 Der Lawrencer Anzeiger advertised that it had the "largest circulation of any German newspaper in New England."117

Meanwhile the Germans in Manchester read the New Hampshire Post, which had been publishing since 1890. In 1894 Max E. Trumpold took over publication of the paper and renamed it the Manchester Post. Max Trumpold was born in 1861, also in Glauchau, Saxony, and by 1882 he worked as a proof-editor and editor of the Glauchauer Zeitung, which was known earlier as the schonbürger Anzeiger. He then got caught in the "emigration storm," and left for America in 1883.118 he soon found a position as foreman of the "technical department" of the Lawrence Eagle. In holding such a position, Trumpold must have had some knowledge of English, though this is not entirely clear. By 1890 he was a foreman for the (Lawrence) Evening Tribune. 119 In 1894 he moved to Manchester, where he purchased and published the Manchester Deutsche Post, which he advertised correctly "as the only German newspaper published in the state of New 
Hampshire," and perhaps with a little exaggeration he claimed that it "circulates especially well among the thousands of Germans of Manchester, N.H. and Lawrence, Mass."120

Whatever the claims of the newspaper advertisements in the two cities, better business sense probably prevailed, and Trumpold and Dick merged their newspapers, publishing the newly founded Anzeiger und Post on october 3, 1896, with Manchester, NH on the masthead. In the announcement to readers the paper proposed a "substantial newspaper for our great cities [to] serve every German reader of Lawrence, Manchester, and neighboring cities."121 It promised to report on items of importance to Germans in their mother tongue, to report on "our Vereinsleben," and to inform the readers about German candidates for office. 122

The firm of Dick and Trumpold delivered on its promise to the German communities, publishing the Anzeiger und Post until 1942. The paper became a family matter. Sons william Dick and Carl and Frederick Trumpold were brought into the business and assumed control upon the deaths of the founders. Throughout its history, the owners and editors of the paper were involved in the Vereine of the two textile cities, and promoted Deutschtum in both. The company became the print shop for the bulletins, programs, and raffle and admission tickets of the numerous Vereine. They were also favored with city printing contracts and other printing jobs including a history of Lawrence published in 1918.123

The symbiotic relationship between the newspaper and 
Vereine continued for 46 years. During that time the paper extolled both the virtues of German culture and the values of American liberty, and it made other attempts to influence the opinions of the German-Americans. The appeal of the paper is perhaps summed up by one resident of Manchester who recalled, "everyone waited for it."124 However, the circulation and influence of the paper is hard to judge, and other residents claimed not to have purchased the newspaper. 125 The newspaper outlasted most of the German language papers in Massachusetts, and probably picked up circulation as a result. In the 1920 s and 1930 s it contained German reports from clinton, Holyoke, Springfield, and sometimes Providence, no doubt, in an attempt to broaden circulation to those cities.126 Ayer's Newspaper Annual and Directory, whose figures were probably estimates and cannot be verified today gives the circulation figures for the Anzeiger und Post. The figures are in Table 5.5. 
TABLE 5.5

ANZEIGER UND POST CIRCULATION FIGURES 127

$\begin{array}{ll}1890 & 1,100 \\ 1900 & 2,200 \\ 1910 & 4,200 \\ 1920 & 4,000 \\ 1930 & 2,700 \\ 1936 & 9,600 \\ 1940 & 6,000\end{array}$

Source: N.W.Ayer and Sons, American Newspaper Annual and Directory for years given.

Since circulation lists do not survive, it is hard to know how widely the paper was distributed. The Ayer figures would indicate that in 1890 one issue was published for every two (2.4) German-born residents of Lawrence and Manchester, with a slight decrease to one issue for every 1.6 German born in 1900. Such figures would seem unlikely, but the newspaper's circulation in the other cities was not available, and not taken into account. For a time around 1910 there was another German paper in Lawrence which was bought by Dick and Trumpold in 1912.128 The circulation remained relatively consistant before and after World War $I$. The increase in 1936 and high numbers in 1940 could indicate renewed interest in Germany, and the lack of German-language newspapers in other Massachusetts cities. It seems high for several reasons. The number of individuals able to read German was smaller at that time. Furthermore, German- 
language newspapers still existed in Holyoke, Springfield, and Boston.

German immigrants, who had previously overlooked Manchester and Lawrence, settled the two cities during the last three decades of the nineteenth century. Many came seeking employment in the vast textile mills. Others soon found opportunities to start businesses. once the immediate challenges of finding employment and lodging were resolved Germans organized churches and societies. As the community became established and prospered, additional societies and benefit aid organizations could be supported. BY the 1890s, German-Americans attended numerous Verein events, musical performances, German theater shows, and lectures. German citizens could afford to purchase the local German-language newspaper, which in turn supported their Vereine and the German cultural activities of the cities. The German-American community and German district were much like those in America's big cities, although smaller, of course. Deutschtum in Manchester and Lawrence was about to enjoy a time of activity and success. 
${ }^{1}$ Although there were few if any Germans in New Hampshire during its early pelod, a little known side light to history occured there during the Revolution. Friederich von steuben landed in Portsmouth, New Hampshire on December 1, 1777; dined with Governor Langdon: wrote to Congress from Portsmouth offering his services to the continential Army including a letter of indroduction from Benjamin Franklin; and departed on December 12 for Boston. The "self-styled Baron" Von Steuben later became drillmaster to the Continential Army and played an important role in leading that army to victory. See Friedrich Kapp, The Life of Frederich William von steuben, Major General in the Revolutionary Army, (New York, Mason Brothers, 1859), pp. 94-97.

${ }^{2}$ statistics compiled from Population Tables of the U.S. Census from 1860 through 1940. Estimates are from the Manuscript Census Schedules for Manchester and Lawrence.

${ }^{3}$ Statistics compiled from population Tables of the U.S. Census from 1890 to 1940 .

${ }^{4}$ The German-born population of Lawrence shows a decline in 1910. A complicating factor with Lawrence is the number of people living in Methuen. The Prospect Hill section of Lawrence crosses the border into Methuen. The Arlington Mill, stretched from Lawrence through Methuen. A number of Germans lived in Methuen at this time, including the officers of several of the Lawrence Vereine, whose addresses were listed in the Methuen Directory. Unfortunately, Methuen was not large enough to have its population listed by place of birth in the Census Reports. Thus, it cannot be determined if the German-born were divided between Lawrence and Methuen, accounting for the slight drop between 1900 and 1910 .

${ }^{5}$ U.S. Bureau of the Census, Twelfth Census, 1900 , Population, Vol I. pp. 629, 797. The total population of Lowell was 94,969 , of which 40,974 were foreign born. of the latter there were only 164 persons born in Germany.

${ }^{6}$ Some indication of the reputation of Manchester and Lawrence can be seen from the Werdauer Heimat Blytter, March 3, 1927 in its column "Aus der Werdauer Chronik;" 
Uberaus gross war vor 60 bis 70 Jahren fast allenthaiben in Deutschen Industriegebeten die Weberfamilien, deren zahl mehr und mehr zurückging. Die Not zeitigte auf Grund einer gewaltig aufruttelden Rede des Feuertopfes August Bebel anlasslich des 1 deutschen Webertages in Berlin vor 70 Jahren, an dem 51 Delegierte aus 77 deutschen orten, darunter aus Werdau und Crimmitschau, teilnahmen, die "Vereinigung aller deutschen Manufacturerabeiter auf internationalaler Grundlage." 10 Jahre sp\&ter, i. J. 1881, wanderten zahireiche heimlische Weber nach Nordamerika auf Erund versprochener "goldener Berge" aus. In Massachusetts fanden sie Arbeit in Fabriken, wo die Webstühle durch das Wasser des Massachussets River getrieben wurden. Einen Monat lang bekamen die Haus- und Handweber, die in der Heimat ihr altes Gewerbe nach den zunftsgesetzen der vater gelernt hatten, nichts. Sie gingen deshalb nach Pietsfied (sic), nach Lawrence und Manchester, wo sie ununterbrochen 12 stunden ohne Frühstücks und Wesperpause, mit nur einter stunde Mittagspause bei 1/2 Dollar Tageslohn arbeiten mussten. Infolge der Erschütternden Briefe, die in der Heimat eintrafen, reisten die Reichstagsabgeordenen Fritzsche und Viereck zum "Studium der Amerikanischen arbeiterverhaltnisse im Auftrage der Arbeiterpartei nach Amerika. Der Dichter Hauptmann schrieb in jener zeit nach schlesichen Verhaltnisse seinen Schauspiel "Die Weber."

Even if the geography is slightly in error, the reputation of Manchester and Lawrence as textile cities where one could find work was established, if overblown.

${ }^{7}$ Unfortunatly, there are no known surviving letters from Manchester and Iawrence to Germany. Professor Wolfgang Helbich of the Bochum Immigration Letter Collection Center (BABS) and Professor Walter D. Kamphoeefner, who was at the Center at the time, searched the center and discoverd no letters. Letter from Walter D. Kaemphoefner, March 4, 1992 to author: and meeting with both professors at German Historical Institute, Washington D.C. March 30, 1992. None were uncovered among the contacts in Manchester and Lawrence. Perhaps, in the future, with the changed political situation in Saxony, some letters may be found.

${ }^{8}$ Walker, Germany and Emigration, pp. 63-64, indicates that all attempts to discredit American and all official inquiries did little to dampen emigration.

${ }^{9}$ Amoskeag Manufacturing Company, Payroll Book New Mills, No 5. "g," 1879-80. (MHA) Payroll for March, 27, 1880 a pay period of 24 days. 
${ }^{10}$ Consular Dispatches, Leipzig (T215) Number 13, June 3, 1883; Chemnitz (T380) Number 38, December 12, 1885. See above pages 119-120.

${ }^{11}$ From U.S. Census ofice Ninth Census, 1870 , population, and Tenth Census, 1880 , Population. A provincial breakdown is not reported for Manchester. From the Tenth Census, 1880 , Manuscript Schedules, for Manchester similar ratios can be identified. Of the approximately 250 Germans identified, 83 are listed as Germany (probably the result of laxiness or unfamiliarity), but the largest number reported for any province is saxony at 62 .

${ }^{12}$ Information obtained from the obituaries in the Anzeiger und Post between 1889 and 1817 .

${ }^{13}$ This information was taken from the obituaries in the Anzeiger und Post from 1901 to 1933,1934 to 1939 and 1942 . All years not complete. only individuals born in Germany were considered.

${ }^{14}$ Kamphoefner "'Entwurzelt oder verplanzt, " 332. Kamphoefner, Westfalians, pp. 81-85. Kamphoefner "Background Factors Affecting Emigration," 174-201. K81lmann and Marschalck, "German Emigration to the United States," 516547. Marschalck, "Deutsche Uberseewanderung im 19. Jh," 5125 .

15 Kamphoefner "'Entwurzelt oder verplanzt, '" 332 . Kampshoefner Westfalians, pp. 81-85. Weisinger, "Einwander Kolonie von Holyoke."

${ }^{16}$ Anzeiger und Post, 1900-1917. Obituries.

17 There were a few Germans listed in the Manchester Directory, 1864 as working in the gun factory. Some possibilities include: Gustave olenhausen, Valentine Pieffer, A. Schoefold, and Edward Tissel.

18 Browne, The Amoskeag Manufacturing Company, p. 81 . The Directors' Minutes and correspondence of the Amoskeag during this time were reviewed. The History of the Amoskeag Machine Shop at the Manchester Historical Association was also reviewed. No specific reference was found regarding the specific recruitment of German gunsmiths.

${ }^{19}$ U.S. Census office, Eighth Census, 1860, Manuscript Schedules for Manchester, and Manchester Directory, 1866.

20 Thorp I. Ashton, Manchester of Yesterday, (Manchester, Granite State Press, 1939). p. 425: Gingham "was the most popular fabric in daily use for womens wear at that time. Gingham required skillful and careful preparation and 
handling in both dying and weaving." p. 449: At its height, "The Amoskeag was running over twenty thousand looms, twothirds of which were producing some type of ginhams either plain or fancy."

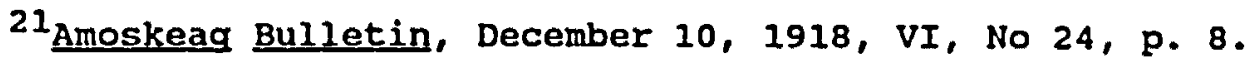
22 Amoskeag Employee Room Register, 1854-1878, Vol I.

23 Amoskeag Manufacturing Company, Payrol1 Book New Mills, № 5, "ge" 1879-80. Payroll for March, 27, 1880 .

${ }^{24}$ Amoskeag Bulletin, February 1, 1914, II, No. 5, p. 6. At the time of the mill closure this room had 576 looms. Amoskeag Industries, Inventory and Valuation of Amoskeag Manufacturing Equipment, not dated, approximately 1936. (MHA box 6 folder 11).

25 Amoskeag Bulletin, February 1, 1914, II, No. 5. p. 6. Manchester Directory, 1895, 1900, 1905, 1910.

${ }^{26}$ Amoskeag Bulletin, April 15, 1920, VIII, No. 8, p. 1. 27 Ibid., Aug 1, 1916, IV, No. 15, p. 5 .

${ }^{28}$ Ibid., July 1. 1916, IV, No. 13, p. 4.

29 Ibid., June 1, 1916, IV, No. 11, p. 5.

30 Ibid., May 15, 1916, No. 10, p. 5 .

${ }^{31}$ Ibid., Dec 30, 1916, V, No. 1, p. 5. Jan 15, 1917, V, No. 2,p. 6. Oct 1, 1917, V, No. 19, p. 4. April 15, 1918, VI, No. 8, p. 9 .

32 For instance, $J$. Adam Graf had a brother George Graf who was employed at the Amoskeag since 1865, Amoskeag Bulletin, October 16, 1913, I, No. 22, p. 4. Also Fred Artz started in the Mill in 1881 and his brother Albert in 1882, Amoskeag Bulletin, April 15, 1920, VII, No 8, p. 1 and April $1,1917, V$, No. 19, p. 4.

${ }^{33}$ Amoskeag Manufacturing Company, Payroll Book New Mil1s, NO 5, "g," 1879-80. Payroll for March, 27, 1880 . Among the listings were August, John, Julius and Fred Hoffmann; Hermann and F.E. Poehlman; H. and O. Engelhardt; Fred and Frank Vogt; and Louis and August Gersbacher.

${ }^{34}$ Hareven, Family Time, Industrial Time, clearly demonstrates the system of relatives vouching for relatives for jobs. See especially pp. 62-64, 85-88, 90-91, 94-96, 99101. 
${ }^{35}$ Anzeiger und Post, June 30, 1917.

${ }^{36}$ Anzeiger und post September 28, 1908.

${ }^{37}$ Leading Citizens of Essex County, Massachusetts. Biographical Review, XXVIII, (Boston, Biographical Review Company, 1898), p. 173.

${ }^{38}$ The American Woolen Company Employee Booster, September, 1922, VII, No. 3, p. 34 .

${ }^{39}$ Anzeiger und post, February 17, 1906.

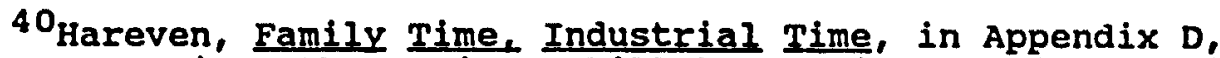
pp. 388-389 gives the varicus skill levels in the mill and in Appendix F, pp 396-410 describes the jobs.

41 Manchester City Directory, 1880, 1885, 1890. Manchester Marriage Records 1878-1933. Manchester Manuscript census. $1880,1900$.

42 Hareven, Family Time Industrial Time, p. 16 indicates that Germans were skilled craftsmen. Also table $2.1 \mathrm{pp}$. 1819 shows the number of supervisors among ethnic groups. Hareven concludes tht the Franco-Americans occupied the lowest level positions in the mills and accepted the fact that there was little advancement p. 270. In a chart on p. 283 she categorizes white collar and skilled, semi-skilled and unskilled. Unfortuantely the ethnic categories are U.S., French Canadian, British Isles, Poland and Eastern Europe, and Other. Of the French-Canadians $75 \%$ were semi-skilled and unskilled; for the British Isles it was 78\%; for the Poles it was $64 \%$ for the U.S. born it was $75.5 \%$. This was a sample and the ethnic categories are broad. However it would appear that a higher percentage of Germans were in skilled categories.

43 Manuscript Census for Manchester for 1890 and 1900. Also a review of Marriage Register of St. Raphael Parish, 188-1920, and Manchester Reqister of Marriages, 1878-1933. These are in books at the Manchester city Hall.

44 Lawrence Directory, 1875, 1881, and 1885, US Census, Manuscript Census reports, 1880, 1890, 1900.

45 Anzeiger und Post, Olzendam obituary, December 26 , 1896. Manchester Directory, in 1860 Adam olzendam was listed as a colorer and in 1866 he is listed as a hosiery manufacturer.

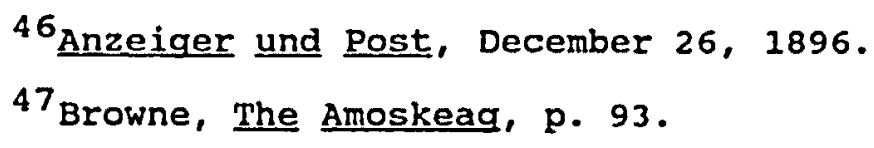


${ }^{48}$ Manchester Directory, 1875 and 1880.

49 Manchester Directory, 1885.

50 Manchester Directory, 1895. Also Manchester Marriage Records, 1878 to 1935. In the review of the marriage records, Germans who married outside of a church tended to be married by Rodelsperger.

${ }^{51}$ Lawrence Directory, 1875. Leading Citizens of Essex County, 173 .

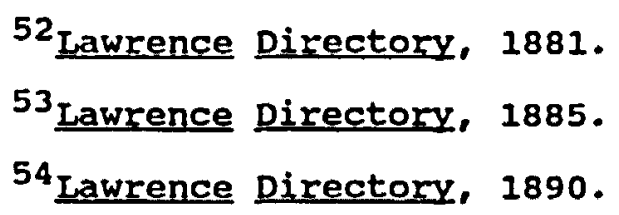

55Lawrence Directory, 1895. John Breen was a colorful individual. He immigrated from Ireland and at one time became involved with the Fenians. He established and operated a funeral home, which is still in the family, and which became the Irish funeral home in Lawrence. He became the first Irish mayor of Lawrence and was a strong politicial figure. His son John Breen, Jr., who also operated the funeral home, was on the school board. He played a part in the dynamite plot during the 1912 strike. See Cole, Immigrant City, pp. 51-56, 87-88, 181-185.

${ }^{56}$ Anzeiger und Post, "Deutsche Brauerei," July 16, 1904. Will Anderson, Beer New England (Portland ME, 1988), pp. 174$5 \mathrm{He}$ interviwed the last Holihan brother, former owner of the Diamond Spring Brewery. He has few details about the cold Spring Brewery. See Also, Dorgan, Lawrence, Yesterday and Today, pp. 246-248.

57 Dorgan, Lawrence Yesterday and Today pp. 148, 254 Lower Merrimack, p. 28. George E. Kunhardt, Lawrence: A Manuracturer's View, (Boston Rockwell and Churchill Press, 1919.) Despite his success and wealth Kuhnhardt apparentiy left few records, and little is known of him.

58 carl Wittra, "Ohio's Geiman's, 1840-1875," The Ohio Historical Quarterly, 66, (October, 1957), 345. The remark is attributed to an unidentified academic in Guttingen.

${ }^{59}$ Manchester Turn Verein, Inc, 100th Anniversary Program, 1970 (authors collection). Anzeiger und Post, "Turnvereins Jubildum, Manchester Turnverein feriert sein fünfzigsjuhriges Festen," April 17, 1920. This report, which is typical of many in the newspaper, goes into great detail about the price of land and buildings and the size of the buildings but does not give membership numbers. 
Unfortunately, no newspapers are in existence for 1895 which may have provided more details. The lo0th Anniversary

Program is mainly a chronological summary.

${ }^{60}$ Lawrencer Anzeiger, "Die Deutsche Schule in Manchester, N.H." November 9, 1889.

${ }^{61}$ Anzeiger und Post, "Festliche Tage der Harugari in Manchester, N.H.", "Das 25 Juhriger Jubildums der Barbarosa Loge 329 D.O.H.," February 11, 1899. The Order of the Harugari was a fraternal organization founded in New York in 1847 and was named for an ancient order of Germanic priests the "Harugari." ordens der Harugari, Grosslogen Massachusetts Buch, 1929-30, (ICA 89.53.07), p. 1. The other German fraternal organization was the Sons of Hermann, which took its name from Hermann the Cherusker (Arminius), who led the Germanic tribes to victory over the Romans in the Teutoburger Forest. Kathleen Neils Conzen, "German-Americans and the Invention of Ethnicity," in America and the Germans, ed. Trommler and McVeigh, 142. Both organizations had a hall, mutual-benefit funds, and a wide variety of activities.

62 Anzeiger und Post, "A-K-U-Verein: Dessen 25 Juriges stiftungsfest grossartig gefeiret," January 23, 1908. From the obituary listings in the Anzeiger und Post, individuals from St. Raphael's parish were listed as members of the A-KU-V and not the Turnverein. The club continues to exist in its building on Douglas street in West Manchester, and consists mainly of a bar and video game room in the front of the building. Several years ago the author visited the club and reviewed the Kassier Bücher, which were stacked in an upstairs closet. In the back was a large hall with balcony and a stage. Behind the stage hung a large backdrop painting of an alpine scene.

${ }^{63}$ Anzeiger und Post, "25 Juhriges Stiftsungsfest und Fahnenweitze des Manchester Mannerchor," July 18, 1908. Little information is apparently available on the Beethoven Mannerchor. In the 1905 Manchester Directory the Beethoven is listed with a foundation date of 1895. The club had a hall on Blaine street.

${ }^{64}$ Anzeiger und Post, April 3, 1997.

65 50JArige Jubiltum Lawrence-Turnverein, 1916 , (ICA 90.137.7) The first Turnhall cost $\$ 2675$ in 1868 . In 1894 the rebuilding contract was awarded to Ernst A. Dick, for a sum of $\$ 28,381.51$.

${ }^{66}$ Harugari Hal1 Dedication Book, 1912, (ICA 78.10.8). 
${ }^{67}$ Anzeiger und Post, February 8, 1908, (25th. Anniversary issue of the Newspaper)

${ }^{68}$ Anzeiger und Post, February 8, 1908.
${ }^{69}$ Anzeiger und post, February 8, 1908.

${ }^{70}$ 60th. Anniversary of the German School Association, 1935, (ICA 78. 18.37). The school was still in operation in 1966. See Lawrence Eagle Tribune, October 5, 1966. In 1992 the building, which had converted to appartments, was damaged by fire, see Eagle Tribune, August, 24, 1992.

${ }^{71}$ From listings at the Immigrant city Archives, and listings in programs such as Deutscher-Zentral-Verband membership list in the sungerfest program, 1936. Deutsches Freibett Komitee Protokol und Kassier Bucher, 1892-1917, and 1917-1941.

72 Bayrischer Lese-und Fortschrittsverein, 25 Jahriges Jubiluum, (ICA 79.9.11) 1915. See also 50th. Anniversiary, 1940 (ICA 79.9. 15), and 100th 1990, (ICA 91.4.12). Anzeiger und Post, "B.L \& F. V. "weiht sein neues Heim," october 3, 1896. The Bavarian Reading and Progressive Society exists to the present day, in the same building, but with little connection to Bavarians or Germans. Alsatian Sick Benefit Society card at the Immigrant city Archives. Little is known about this society. There are advertisements for its activities in the Anzeiger und Post.

${ }^{73}$ Concordia Schutzenverein, 60th Anniversary Program, 1886-1946. (ICA 78.1.8) The Concordia Social Club exists to the present in the original building, but like the other clubs is no longer German in nature. In 1991, the president of the club was Barry Daley. His great-grandfather was one of the original members. Letter from Barry Daley to author, June 26, 1991.

${ }^{74} \mathrm{H}$. Richard Niebuhr, The Social sources of Denominationalism, (Cleveland, Meridian, 1962), p. 223

$$
\begin{aligned}
& { }^{75} \text { Ibid., p. } 110 . \\
& { }^{76} \text { Ibid., p. } 211-212 \text {. } \\
& { }^{77} \text { Niebuhr, Sources of Denominationalism, pp. } 211-214 .
\end{aligned}
$$
Hrold Abrahmson, "Religion" in Harvard Encyclopedia of American Ethnic Groups, ed. Stephan Thernstorm, 150-160. Timothy L. Smith "Relition and Ethnicity in America," American Historical Review, 83 (December, 1978): 1115-11185.

${ }^{78}$ For information about the German catholics and their languange battles with the hierarchy see Coleman Barry, The 
Catholic Church and the German Americans, (Milwaukee, The Bruce Publishing Co, 1953): and Jay P Dolan, The Immigrant Church: New York's Irish and German Catholics, 1815-1865, (Baltimore, Johns Hopkins Press, 1975).

${ }^{79}$ Sydney Ahlstrom, A Religious History of the American People, (New Haven, Yale University Press, 1973), pp. 245246.

${ }^{80}$ Andrew Landale Drummond, German Protestantism Since Iuther (London, Epworth Press, 1951), p. 15.

${ }^{81}$ Ibid., pp. 57-8.

${ }^{82}$ Ibid., $176-177,180,200$.

${ }^{83}$ Alhstrom, Religious History, pp. 248-249.

${ }^{84} \mathrm{Niebuhr}$, Sources of Denominationalism, pp. 227-228.

${ }^{85}$ William T Parsons, "The Pennsylfanisch Dietsch Community for Independence, 1758-1783," in Germany and America, ed. Hans L. Trefousse, 77.

${ }^{86}$ Minutes of the Session, 1882-1930, First, German, Presbyterian Church, Manchester.

${ }^{87}$ German Presbyterian Church, Lawrence, Funfzigiuhrigen Jubiluum, 1876-1926, (ICA 91.94.01). Christ Presbyterian, 100th Anniversary. 1872-1972, (ICA 89.35.10).

${ }^{88}$ German Presbyterian Church, Lawrence, Funfzigiahrigen Jubilaum, 1876-1926 (ICA 91.94.01) . Christ presbyterian, 100th Anniversary. 1872-1972. Anzeiger und Post, July 7, 1900. Lawrence Tribune, April 28, 1926.

The maps in the Lawrence Directories identify the German Church on East Haverhill street incorrectly as Lutheran. It was the German Presbyterian Church. The Lawrence Atlas correctly identifies it. This probably reflects the assumption that 'Germans were Lutherans.' A Presbyterian congregation is still at the chruch building.

${ }^{89}$ German Presbyterian Church, Manchester, Minutes of the Session, 1882-1930. Minutes begin with "Historical sketch" dated 1882. 100th Anniversary Phamplet, (author's collection).

${ }^{90}$ German Presbyterian Church, Manchester, Minutes of the Session, 1882-1930. 100th Anniversary Phamplet. The First Presbyterian church continues in existance and occupies the original building in West Manchester. A number of the members, especially the older ones are of German descent. currently, there is a visiting minister from Boston. 
${ }^{91}$ Assumption B,V.M. 100th, Anniversary Booklet, 1987 , (author's collection). Anzeiger und Post, February 8, 1908 . The church building remains today and it is now a mission to the Hispanic community.

$$
\begin{aligned}
& 92 \text { A.B.V.M., 100th. } \\
& 93 \text { A.B.V.M.e 100th. } \\
& 94 \text { A.B.V.M., 100th.- } \\
& 95 \text { A.B.V.M., 100th. Anzeiger und Post, February 8, } 1908 \text {. } \\
& 96 \text { Anzeiger und Post, February 8, 1908. } \\
& 97 \text { Bishop Denis Bradiey to Father John Edwards, November }
\end{aligned}
$$
22, 1886. All of the correspondence cited is in the Archives of St. Anselm Abby, Manchester, NH.

${ }^{98}$ Bishop Bradley to Abbott James Zillox, May 18, 1887.

99 Father Sylvester Joerg to Abbott Hillary Praengle, April 12, 1888 . 1889.

100 Bishop Bradley to Abbott Hilary Praengle, March 23,

${ }^{101}$ Abbot Hilary to Bishop Bradley, December 20, 1893 and again on March 11, 1898. For more details on the college see Valerie McKeon, "The Founding of St. Anselm: New Hampshire's First Catholic College, Historical New Hampshire, 41 nos 1 and 2 (Spring and Summer, 1986): 21-44.

${ }^{102}$ St. Raphael's Church, Centennial Year, 1888-1988, (author's collection).

${ }^{103}$ This particular data is not conclusive, but their were far fewer burials listed in the Anzeiger und Post, from St. Raphael's than from Mariahimmelfahrt. The Manchester Manchester Register often list place of birth as Austria, but the names are not German but Hungarian or Czech in origin.

${ }^{104}$ Anzeiger und Post, February 8, 1908.

105 Manchester Directory, 1905.

$106 \mathrm{Niebuhr}$, Sources of Denominationalism $132-133$ says "After all, the German church is not only German but also Lutheran..."

107 Manchester Directory, 1905. The Emanuel Lutheran Church in Manchester was contacted. All records from the early years were destroyed in the flood of 1936. Columns in 
the Anzeiger und Post and the Manchester Union list service times and special activities for the church.

${ }^{108}$ The Evangelical Lutheran Church of the Redeemer, Twenty-fifth Anniversary Booklet, 1930-55. In addition the Lawrence Directory lists no Lutheran Church prior to 1930, Lawrence Directory, 1930. The Anzeiger und Post contains no church listings for a Lutheran church in Lawrence. There was apparently no German Lutheran Church in Lawrence prior to the founding of the the church of the Reedemer in 1930. The older residents can recall none.

${ }^{109}$ The Lawrencer Anzeiger was published from 1883 to 1896. The Manchester post from approximately 1894-96, and there are apparently no surviving issues. The Anzeiger und post from 1896-1942. The latter was a weekly, appearing on Saturday. The Lawrencer Anzeiger is available for 1877 , 1889-1891 at the Manchester Public Library. The Anzeiger und Post for 1896, 1897-1899 at the New Hampshire Historical Association, Concord NH, 1900-1933 at the Peabody and Essex Institute, Salem, MA, 1934-36, 1936-38. and 1939 at the Institut für Auslandsbeziehungen Bibliotek, stuttgart, and 1942 at the New England Repository, Cambridge, MA. The Peabody and Essex is in the process of obtaining from the Institut für Auslandsbeziehungen copies of their microfilms. All years are not complete.

110 The advertisement of the Anzeiger und Post claiming wide coverage is from the Lawrence Directory, 1898-99, p. 680 .

${ }^{111}$ Carl Wittke, The German-Language Press in America, (Lexington, University of Kentucky Press, 1957), pp. 200-201.

112 James M. Berquist, "German-America in the 1890's: Illusions and Realities," in Aspects of German-American Relations in the Nineteenth Century, ed., E. Allen McCormick, (New York, Columbia University Press, 1983), 4.

${ }^{113}$ Wittke, German-Lanquage Press, p. 7. Raster's speech was in 1882. No date is given for Carl Schurz's remarks.

${ }^{114}$ Ibid. , 220-221.

115 Ibid. , 221-222.

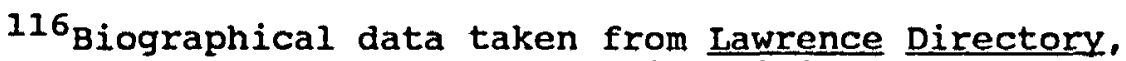
1875, 1880, 1885, 1895, 1898; Leading Citizens of Essex County, 173; Anzeiger und Post, February 8, 1908, and January 18, 1919 (obituary).

${ }^{117}$ Advertisement in Lawrence Directory, 1890. 
${ }^{118}$ Anzeiger und post, February 8, 1908.

119 Biographical data taken from Lawrence pirectory, $1885,1890,1894-5$, Manchester Directory, 1895; Anzeiger und Post, February 8, 1908, and December 7, 1929 (obituary).

120 Advertisement from Manchester Directory, 1895.

121 Anzeiger und Post, October 3, 1896. The paper continued its antecedents from the Lawrencer Anzeiger, so the 1896 issuse was Year 14, issue number 1. Thus its october 8, 1908 issue celebrated the paper's 25th. year.

122 Anzeiger und post, october 3, 1896.

${ }^{123}$ Hugo Dick hanged himself, for unexplained reasons in 1919. Anzeiger und Post, January 18, 1919. William Dick was probably already in the business, Lawrence Directory, 1920. Max Trumpold died of natual causes in 1929, and by that time Carl and Frederick Trumpold were in the business, Anzeiger und Post, December 7, 1929, obituary and memorial advertisement. The company publised Hertha the semi-monthly official of the German Sons of Hermann of Massachusetts. In its March 18, 1908 issue it announced that it had obtained the contract to publish city documents for a year. It was the publisher for Maurice Dorgan's Lawrence Yesterday and Today, 1918. Anniversary books, programs and tickets at the Immigrant City Archives, in Lawrence were printed by Dick and Trumpold. In a full-page advertisement in the Lawrence Directory of 1930, the paper billed itself as the "leading German Newspaper in New England." In addition to the Hertha it published the Harugari ordensblatt for Illinois and Der Hermanns-Sohn of Connecticut.

${ }^{124}$ Interview conducted by author with Mrs. Elsie zindt, Manchester, NH, March 17, 1986. Mrs. Zindt and her late husband were very active in the Manchester Turn Verein, and as such were likely to be regular readers.

${ }^{125}$ Interview conducted by the author with Mr. and Mrs. Herbert Paul, Manchester, NH, December 18, 1981. Herbert emigrated in 1927 and Helen emigrated in 1928. He was sponsored by an aunt in Manchester, and she was sponsored by an aunt in New York. They met on the boat on a return visit to Germany. They were married in Manchester, and he operated a painting business. They said that they did not subscribe to the Anzeiger und post. They did send their children to classes at the German school.

${ }^{126}$ Karl Arndt and Mary E. Olson, German American Newspapers and Periodicals, 1732-1955: History and Bibliography (Heidleberg, Quelle and Meyer, 1961) pp. 201208, list possible competitor papers for the years under 


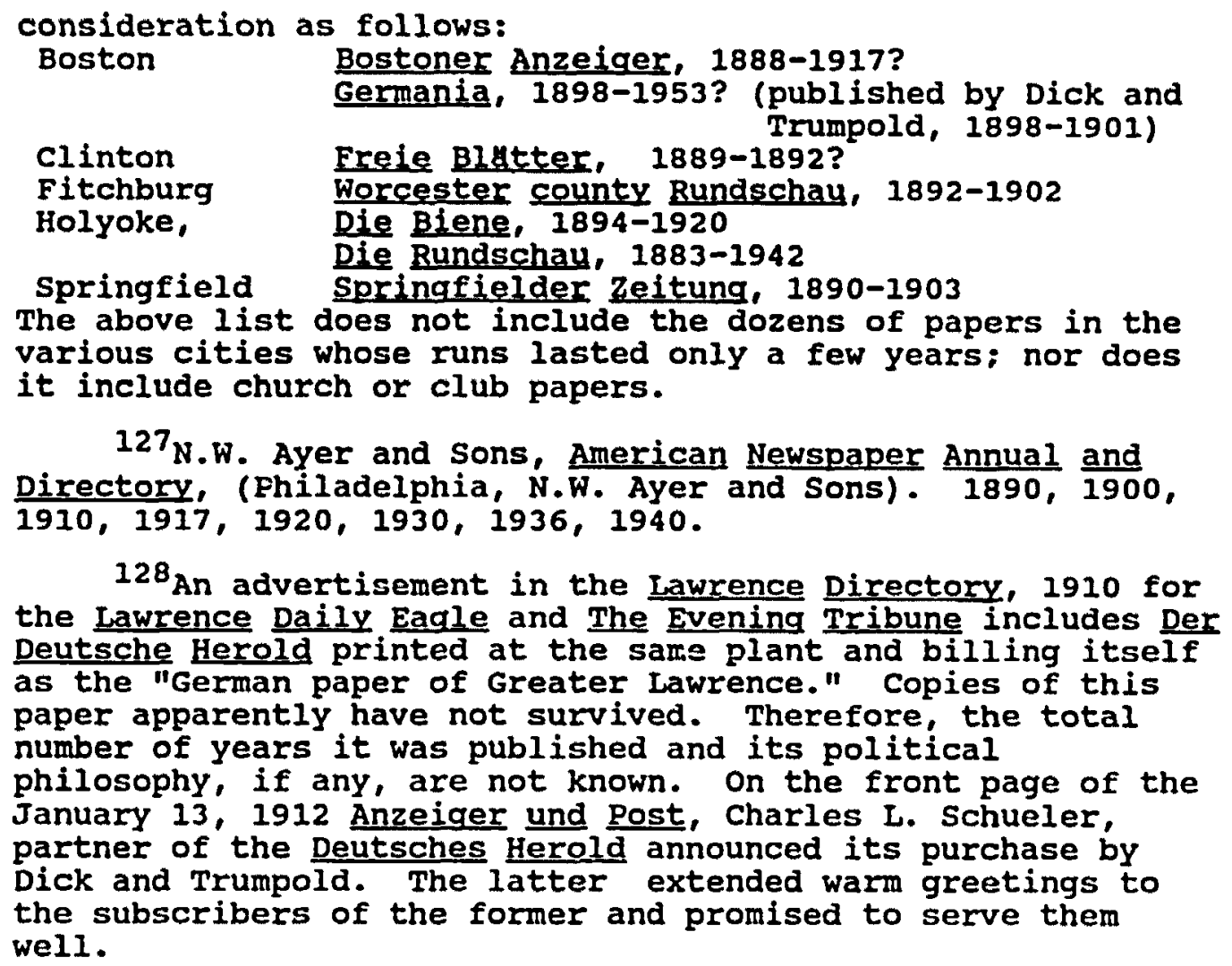




\section{CHAPTER VI}

\section{HIGH HOPES FOR DEUTSCHTUM, 1900-1914}

In the first decade of the twentieth century GermanAmericana attained the zenith of its influence and respect throughout the nation. The German-Americana of Manchester and Lawrence enjoyed its greatest glory at the same time. The Vereinsleben was active, exciting, and growing. There were German theater performances and performances by German singing societies and bands were enjoyed by Germans and nonGermans alike. On occasion, the New England festivals or meetings of various Vereine were held in Manchester or Lawrence increasing local pride and adding activity and excitement for the local verein. The Anzeiger und post was extolling the virtues of German culture and especially German language. It seemed quite plausible to praise the special nature of the German-American and extol American liberty at the same time. Underneath Deutschtum, however, Americanizing influences were felt--the loss of the language in the younger generations, a decrease in immigration, and the necessity to work, shop, or do business in the larger, overwhelmingly non-German community. The apparent isolation of Manchester and Lawrence from the mainstream of GermanAmericana was considerably reduced by the involvement of Germans in both cities in the German-American National 
Alliance. The Alliance formed in 1901, fostered interest in Deutschtum and represented German interests early in the twentieth century. The editors of the Anzeiger und post were behind this involvement, and they arranged for visits of the president of Alliance to both cities and promoted elaborate "German Day" celebrations. A key ingredient in fostering the optimism of this era was the widening influence of the Vereine.

In Manchester and Lawrence the years between the turn of the century and World War I, would be good ones for the Vereine. Vereine-sponsored events proliferated, membership increased, halls were expanded, and sub-sections for women were added. Community wide benefit societies, especially the "Free Bed Society," and the "German Old-age Home" gained support. Before detailing some of these local events, the significance of the Vereine must be explored.

Historian James Berquist contends that the apparent strength of the Vereine around the turn of the century was an illusion. He contends that the Vereine were flourishing from the 1890 s into the early 1900 s because they were both preserving the known German culture and easing the transition of the new members to America. However, as German immigration dropped the only remaining function of the clubs was to maintain the German culture, and this could not save them from a slow decline. 1 It is his view that:

Whenever institutions undertook to bind all Germans together by gaining the support of the entire community they had to make their appeals to the 
lowest common denominator. This often meant exaltation of a sort of homogenized culture, combined with a studied avoidance of any hint of controversies frequently rife among Germans. The Turner societies of many communities, once a focus of radical ideologies, became increasingly apolitical and less ideological as they sought to become a social center for all Germans in the last decades of the century. ${ }^{2}$

Furthermore, according to Berquist, once the original immigrants passed from the scene, the clubs depended on the second generation and their main function became one of preserving the old culture. Many members of the second and third generations who were more Americanized were not attracted to the clubs. 3

These conditions apply to Manchester and Lawrence, with the important caveat that "illusions and realities" continued into the 1930s. Germans arrived here rather late, and continued to come, albeit in smaller numbers, into the early years of the twentieth century. Some members of the first generation continued to wield influence until the late 1920 s and early 1930s. For instance, editor Max Trumpold died, at the age of 68 , in 1929. During this period some members of the second generation were assuming leadership roles in the Vereine. World war I was a setback but not a fatal blow. Members of the third generation kept some of the Vereine alive into the 1960 s or 1970s. However, most of the third generation and practically all of the fourth generation were moving forward toward the new homeland rather than backward to the old homeland. 4

The efforts and successes of the Vereine in preserving 
the old culture and in aiding in the Americanization of its members is open to interpretation. According to one scholar:

The German-Americans actually proved singularly ineffective as a bridge between their old and adopted countries. For one thing, the German Kultur they tried to preserve had a decidedly petit bourgeois and dated quality. In an endless variety of clubs or Vereine, devoted to everything from gymnastics and shooting to singing and bowling, the German-Americans kept alive the pastimes their forebearers had known rather than keeping up with more mociern elements. 5

It is clear that there was a multitude of clubs and activities for the Germans in Manchester and Lawrence. 6 It also true that the leadership and membership of the clubs in Manchester and Lawrence was of the middle class and skilled laborers. The leaders and members of the clubs depended on both sales to the Vereine and their members. Among them were the brewery owners, the editors of the Anzeiger und Post, grocers, restauranteurs, lawyers, etc. 7 Their continued involvement helped the Vereine maintain themselves.

The number of Vereine in the two textile cities was quite extensive. For instance, in 1900, there were eighteen different Vereine in Lawrence and eleven in Manchester, not including church organizations. By 1910 the distinctive Vereine in Lawrence had grown to twenty-seven; including the women's branches and sub-clubs within clubs the number was forty-eight. In Manchester the number remained stable at twelve, but women's branches added another five clubs. Both cities had active German churches each of which had men's, women's, and youth societies. Lawrence's Germans could select among eight singing societies, pursue physical 
activities in the Turnverein, bicycle club, or shooting club. One could elect a sick benefit, a free hospital bed or a natural healing society. The fraternal societies were represented by the German order of Harugari, and the German Sons of Hermann. In Manchester, for a short time, one could join the Manchester Turn Verein or the Turnverein Germania; the latter apparently was for individuals with socialist convictions. 8

In Lawrence the Deutsches Freibett Kommitee and the Deutsches Altenheim, two city-wide organizations transcended, all of the other divisions among the Germans. Individuals paying into the first could obtain a "free bed" should they require hospitalization in the Lawrence General Hospital. The Deutsches Altenheim was an old age home for Germans. There was particular pride in the opening of Das neue deutsche Altenheim in 1913. The home continues in operation to this day, under the name "German old Folks Home." 9

Although fewer in number than the vereine of the large "German" cities of the mid-West, the vereine of Manchester and Lawrence were proportionally more extensive. For instance in 1910, in Manchester there was one Verein for every 102 persons born in Germany, in Lawrence one for every 77, whereas in Cincinnati there was one for every 341 persons born in Germany and in st. Louis one for every 195.10 Thus, the much smaller German populations of Manchester and Lawrence actually supported more German clubs. The major Vereine, including several of the "singing 
societies," had a club building or hall, which usually expanded as the club grew and became prosperous. The Vereinhallen often large and elaborate buildings, could handle many club activities. There was always a room for eating and drinking, a kind of a pub or Gaststube; a kitchen and room for serving meals for events and festivals; a ballrocm usually with a stage and balcony which could be used for dances, band or singing performances, and lectures; meeting rooms: and lounges. Depending on the nature of the Verein they may have had some or all of the following, bowling alleys, library, exercise room, an outdoor eating or beer garden area, and an outdoor recreation, concert, or marching area.

The clubs depended upon a number of sources of revenue, in addition to modest dues. These included the regular sale of beer and meals, the attendance of members and others at Verein sponsored festivals, concerts, dances, lectures, the rental of space to other Vereine for meetings and similar festivals and social events, the sale of beer and food at such events, and other income such as bowling fees. The dances, festivals, and events were advertised in the Anzeiger und Post and attracted members of the verein and other Germans in the two cities, and sometimes from still other New England cities with a German population. The halls became the centers of Deutschtum. 11

There seemed to be an endless stream of events to attend in both cities. Every week the Anzeiger und Post advertised 
many club activities. Holidays allowed almost every club to schedule events, some continuing for several days. American holidays, especially Independence Day and Labor Day, were celebrated in style. Likewise, a variety of German holidays called for elaborate celebrations for such events as spring and autumn festivals, Christmas, New Years, Fasching or Karnival, Easter, and Pfingsten.

A sense of Vereinsleben can be seen from a sample of the activities. Shortly after the dawn of the new century, the Germans of Lawrence had a busy schedule. On Thursday, March 22,1900 , they were treated to a musical evening when all eight of the Munnerchbre sang together in the Turnhalle. Several days later, that saturday, they were invited to attend an illustrated lecture on the Boer War in the CentralHalle. On Sunday there was a family evening in the Turnhalle. The following week they could play cards Thursday evening in the Lyra Halle, and dance at a Bauernball on Friday in the Turnhalle. One weekend later, there was a singing festival held by the Gesangverein Eintracht, and a theater presentation in the Lyra Hall. 12

In February 1906, Karnival time, there were plenty of activities for the Germans of Lawrence. The Hermann Society held a Kostum-Ball and a Lumpen (rag) Ball. The Lyra Society held a Grosses sunger Fest, while the Harugari Society offered a "free lunch" of steamed clams and an evening of cards and other games. In the Turn-Halle there were a Lumpen-Ball and a theater presentation about the small cities 
of Germany. 13

During this time clubs in Manchester advertised less than those in Lawrence. Perhaps the Manchester Germans were not as wealthy as their counterparts in Iawrence, or the clubs were still relying mostly on their own membership. The quality of news and advertisements also depended on the local representative in Manchester, and there were periods when there was none or a rather unproductive one. However, in later years there were more advertisements. It is clear that the Vereine sponsored an active social life. There were elaborate concerts, festivals, and performances. 14

The repetitive and constant nature of these events continued. It is unclear how the small number of Germans could have supported such events in both time and money. Although the admission charges were usually modest, ranging from five cents to fifty cents at most, how the middle and especially the working class Germans could afford to attend so many events is unresolved. It is likely that there was little competition from other activities, e.g. vaudeville, and movie theaters would not become popular until years later. Also, it is known that workers in the industrial city of Worcester were clearly interested in leisure time activities. 15 Unfortunately during this era, attendance numbers were not given in the paper. There was usually the statement that the event was a great success (Grosse Erfolg), perhaps in keeping with the "pleasant news" characteristics of the German language-press. It should be noted, however, 
that the same number and types of events were held both before and after World War I.

Various Vereine organized themselves into a New Englandwide structure. A kind of executive board comprising the officers of the local Verein met periodically in cities around New England. Certain of the Vereine, especially the Turners and the singing societies, held festivals and competitions in the various cities of New England. Such events were a source of great pride for host Verein. There was usually a parade of the visiting Vereine through the city streets, at least in the German section. The singing festivals, especially, attracted non-Germans. One historian believes that not only were non-Germans of many cities entertained by the events, but some cities recognized the business the festivals generated and assisted the societies in building halls for the performances. 16

Manchester was the site of fifth annual singing festival of the Neu England-Staaten sungerbundes in September 1901, and the Beethoven-Mannerchor was the host. Listed among the prize winners were singing societies from Pawtucket, Rhode Island, South Boston, Roxbury, Clinton, Lawrence, Boston, West Roxbury. Roslindale, and Manchester. It was reported that the concert on Sunday was an "immense success." The event also touted as the "greatest musical event in the history of the city."17

Lawrence hosted the New England Turner competition (NeuEngland-Turn-Bezirksturnfest) from Saturday July 2 through 
Tuesday July 5, 1904. In addition to an opening parade, the gymnastics exhibitions and competition, each evening featured a concert and a dance. The event was so large that in addition to the Lawrence Turnverein it involved the Elsasser Krankenunterstutzungsverein. Gesangverein Lyra, Bayerischer Lese- und Fortschrittsverein, Hermannssohne, Harugari-Logen, and the centralverband, thus bringing together most of the major clubs in Lawrence. The festival parade route included a grand review at city hall, and among the marchers were nonGerman groups. 18 In addition to the hosts, the competition attracted Turners from clubs in Boston, Roxbury, Clinton, Webster, Holyoke, Springfield, Fitchburg, olnyville, and Webster. Undoubtedly, a sense of pride and achievement was felt by the Germans and Vereine of Lawrence active in this event. Lawrence's Germans felt confident enough to parade through the streets of the city, and the many ethnic groups residing in the city were tolerant of the German activities.

The involvement of sangerbunde and Turnvereine from other industrial cities in New England clearly indicates that German communities thrived elsewhere in the region and had developed Vereinswesen. Little has been written about the Germans in these other cities. However, these events provide an opportunity to review German-American life in other New England cities. Each of the cities mentioned developed a German district in addition to an active Vereinswesen. Those aspects of the other major cities which relate to Manchester and Lawrence will be discussed briefly. 
A group of investors recognizing the potential of the waterfalis on the Connecticut River incorporated Holyoke, Massachusetts in 1846 and hoped to develop a textile city to rival those on the Merrimack. Instead, Holyoke became the paper manufacturing center of New England and had only two textile mills. The Germania Woolen Mill is of particular interest. 19

August strusberg, the son of a leading textile manufacturer in the Prussian Rhineland, emigrated in 1865 and established the Germania Woolen Mill in Holyoke. Weavers from the Rhineland were soon followed by wool weavers from Glauchau, Saxony. At one point the Germania employed seventy-five percent of the Germans in Holyoke. The ward surrounding the Germania became eighty-eight percent German, the highest German concentration of any New England city. In the $1880^{\prime} \mathrm{s}$, more Saxons emigrated for work in the mills, but they brought socialist labor leanings with them. They soon became labor agitators leading a strike against the Germania in 1885 and again in 1886 against the Germania and the skinner silk factory. In 1886 they lost badly, losing their jobs and influence in German community. They left the local Turnverein forming their own Turnverein-Vorwarts. During the 1880 s a few strikes occurred in Lawrence but none occurred in Manchester. Germans joined other workers in striking, but they did not provide socialist-style leadership. In Holyoke the split between the socialists and other Germans led to the decline of the German community. During the 1890 s Holyoke's 
Germans joined the Irish to gain political control of the city. World War I revitalized Holyoke's German community for a time, and it organized war relief activities. Once the United States entered the war Holyoke's Germans quickly demonstrated their loyalty. 20

A number of Germans also settled in Rhode Island in the last part of the nineteenth century. The majority lived in Providence, but there were also Germans in Pawtucket, Cranston, Woonsocket, and Newport. Among the societies there was a labor or socialist based Turnverein Vortharts in Providence. It later changed its name to Deutsche Turnerschaft, perhaps an attempt to reflect a broader character. 21

The pattern of German religious affiliation in Rhode Island followed a different path than in Manchester and Lawrence. The Evangelical Lutheran denomination was well represented with parishes in both Providence and Pawtucket. There were apparently no German Presbyterian churches. Likewise, Catholic Germans in Rhode Island were not able to found a parish nor maintain the services of a German-speaking priest for any length of time. A small German Jewish cominunity also existed in Providence. 22

Unlike those of Manchester and Lawrence, Germans in Rhode Island would develop successful companies which would gain regional or national reputations. The Narragansett Brewing Company became regionally famous and continued producing until the 1970s. The Jaeger family associated with 
the textile business in Germany since the fifteenth century, emigrated in 1912 and founded the Jaeger Dye company in Rhode Island. Joseph ott, who had worked at Chemnitz (Saxony) plant of the Goeritz Company, one of Germany's largest silk manufactures, emigrated in 1884, and established the Royal Weaving Company. That company was described in 1936 as the largest silk-weaving mill under one roof. 23

In 1900, Boston had the largest German-born population, over 10,000, and the largest total German-American population in Massachusetts. As is the case with the other cities of New England most of these Germans immigrated after the civil War, the famous early nineteenth century intellectual emigres notwithstanding. Despite having the largest German population in the region, the Germans of Boston have not been the subject of any major historical research. 24

Some studies indicate that Germans from the states of Prussia, Bavaria, Baden, and Saxony predominated in Boston. 25 In the opinion of Frederick Bushee, a nativist, the German immigrants were "very commonly peasants, although there are many skilled laborers among them."26 It was likely that there were peasants among the German immigrants, especially among the east Prussians, but it also appears that saxons, especially, held skilled positions in Boston as they often had in New England cities, Chicago and New York. The Germans seemed to be clustered in certain occupations which included bakers, peddlers, cabinet and furniture makers, carpenters, tailors, personal servants, professionals, metal workers, 
merchants, and manufacturing employees. Among the professionals, musicians and music teachers predominated. 27

Boston was a commercial, not a manufacturing center, and what factories it had were small and specialized. Additionally, a number of production facilities to meet consumer needs, such as clothing or tailor shops and cigar manufacturers existed. 28 Therefore, comparisons of occupational level between the workers of Boston and those of Manchester and Lawrence are not possible.

The Germans of Boston had a thriving Vereinsleben with Turners, singing societies, mutual aid societies, fraternal organizations, workers societies, and Landsmannschaften, among others. Germans in Boston tended to live in the Roxbury, West Roxbury, and Jamacia Plain sections of the city, and in neighboring cambridge. Separate clubs developed in each of these sections, much as in Chicago. 29

As illustrated by the festival reports, Germans and their Vereine also existed in Clinton, Fitchburg, North Attleboro, Adams, Malden, Turner Falls, Springfield, Malden and worcester. From time to time, an Anzeiger und Post local correspondent reported for those cities. In several of these cities the singing societies and Turnvereine were active into the 1930 s and beyond. 30 This was remarkable since the German populations of those cities were even smaller than those of Manchester and Lawrence.

Nothing better illustrates the strength of Deutschtum in Manchester and Lawrence, and perhaps in the other cities, 
than the effort to preserve the German language. The committees of the private German schools led the efforts to teach German. In Lawrence, Germans had succeeded in having their language taught in the public high school. Also, the Anzeigex und Post sounded the battle cry for preserving German language and culture.

Almost every issue of the Anzeiger und post during the first fourteen years of the century extolled the virtues of the Germanlanguage, German Kultur, and the German-American. Whether for the editors this policy was commercially driven (persons proficient in the German language would buy a German newspaper), or whether it sprang from a genuine love of German Kultur can not be known with certainty. Most likely both motives were present. For the immigrant the Anzeiger und Post reported snippets of local German news in its column Aus der Alten Heimat. It also reported on American events and issues on the local, state, and national levels. It carried biographies of Washington, Lincoln, and other American figures and it explained the meaning of the Declaration of Independence and the constitution. It explained citizenship requirements. It supported German candidates for local office, thereby tacitly accepting the naturalization of its readers. It was attempting to preserve the German while preparing the American. In a way it had the unenviable task of serving two masters--the German heritage and inevitable Americanization of its readers. As such, it was typical of most of the German-language press of that time. 31 
The Anzeiger und Post made continuous efforts to enhance and continue the use of the German-language. This took the form of articles about the German language, to reports about and encouragement of the German schools, and opinion columns expressing concerns about the increasing use of English. Some of the articles and poems appeared on page one, indicating the prominence given to them by the editors. Sometimes there were additional reports on the "Lawrence" page and on the "Manchester" page. Items were often reprinted from other German-language newspapers, reflecting the editors' sentiments, if not any original thinking. For instance Manchester and Lawrence Germans reading their paper during 1901 undoubtedly noticed the emphasis on the German language. The January 26 issue contained a front page poem Muttersprache, which portrays

...the son pulled by the foreign land who leaves with his father's blessing and his mother tongue... which remains his best friend to which he is always true...

...the mother tongue

makes him the friend of the homeland

... and from year to year

the mother tongue remains most beautiful 32

The editors recognized the situation of the German immigrant in a new country, but they wished to remind him or her of the beauty of the German language. In June, a front page article on Die Deutsche Sprache reminded readers that the German language was full of "power and richness." Although the 
"German always has an open mind and receptivity to the foreign" one should be concerned with the number of "foreign words"33 in the German language. Again, the paper accommodated the new situation but wanted its readers to preserve German.

In 1904, the editors of the Anzeiger und post exhorted its readers to maintain their German. There are at the same time indications of the pervasiveness of English. An article, entitled Die Deutsche Sprache, began with a report of an "American businessman who 'likes to hear good German'"34 and is willing to pay to learn to speak it. The American or the Irishman who supported German and who appreciated German language, culture, or causes was a common theme in the paper and would reappear a number of times especially during World War I. The article then repeated a speech by a German pastor Holz in Denver who lamented that not only were GermanAmericans quickly forgetting German, but also that the children of the Germans in American did not know much of the German language. Holz believed that there was too little instruction and no understanding that "German is the most beautiful language in the world." He exhorted parents to bequeath to "their children genuine German" language. 35 In August, 'Nix Deutsch' reprinted from the Deutsche Zeitung von Memphis, told readers that it was up to the "mothers and fathers to make the opportunity available for their own flesh and blood to learn the mother tongue."36 It continued by observing that although English was the language of the land, 
those who learn German would have many German customers. In September in Lehrt Euren Kindern Deutsch, German parents were told to conduct German lessons at home with their children. When children know two or three more languages it concluded,

It will be easier for them to learn in school... they can think better than other children.... It will lead to a better life....

If this is what you want for your children, you can do no better than give them the German language. 37

These exhortations were not entirely successful. In 1904 the Manchester column lamented "we had up to now a German Presbyterian Church as the seed for the German spirit and the preserver of the German language," but we now must "offer an evening service in English, as a concession to our GermanAmerican youth." These are the "youth who do not use the German school, and have given their parents trouble about learning German."38 Thus, it would appear the exhortations to learn German, for the most part, were not being heeded. The Manchester representative of the Anzeiger und Post, Hermann Eberlin, a language teacher, 39 complained late in 1904 that "one could hardly believe, and it is only too true, that many of our German families here in Manchester have not once read a German newspaper. It is natural that...they would read the English daily newspaper, but not that they do not take the weekly German newspaper."40 Eberlin also felt that the presence of the German-language paper would encourage children to learn the language. That the Germans would read the daily English language paper is recognized; 
but that is also one of the assimilating factors of living in the city.

The Anzeiger und Post continued its exhortations for the Germans of Lawrence and Manchester to speak German and to transmit it to their children. In 1905, the poem "Die Deutsche Sprache" inspired the local Germans to spricht deutsch. 41 In another article, the readers were informed "Uber den 'inneren Werth' der Deutschen Sprache." The German language was the key to opening one's inner worth. It translated Goethe's saying into English: 'the more languages thou know the more you are.' Learning German was to learn about the fatherland and to remember the fatherland. But when your "children no longer want to be 'dutch,' then it is too late to teach them German." 42 Again, there is the attempt to maintain and teach German and a realization that the second generation is becoming Americanized. The Anzeiger und Post underscored this problem when it reprinted portions of an article, "The cemetery of the German language in America" from the Katholisches Sonntagsblatt von Chicago. It lamented that the German-American youth do not love the mother tongue, and that the parents are guilty of this and would therefore have the first place in the cemetery. In the second place in the cemetery of the German language would be the teachers of their own schools, where the instruction is all in English. In the third place would be their businessmen and workers, who instead of reading German newspapers read English ones. 43 In the fourth place would be 
the priests who speak English. In order to remain alive, German must be practiced in the family, school, business and workplace, and church.

Manchester and Lawrence Germans reflected ambivalence about the German language. The conflict can be seen in two the articles, "Lernt English" and "Spricht Deutsch." In the first the writer, possible H.H. Eberlin of Manchester, suggested that although they "maintain German" they should also learn the language of their "adopted Fatherland." Learning English was important for trade and business and for citizenship purposes. 44 only a few months later the writer exhorted the readers to "speak German." He complained that not enough parents were speaking German to the children who are, therefore, not learning it. 45

The year 1905 began in Lawrence with the German paper exhorting parents to send their children to the German School. The schulverein asked the "German press of this city" to ask parents to "regularly send their children to the Sunday language school."46 In fact, the exhortation was a yearly event. In both Manchester and Lawrence, GermanAmerican children attended the local public schools, and in order for them to learn German they had to attend the German School. In each city, classes were held after regular school hours or on Saturday or Sunday mornings. Such a schedule was unlikely to encourage attendance, and as noted above parents were faulted for contributing to the irregular attendance of the children. Attendance at the German Schools was never 
exceptionally high and was relatively consistent. In Lawrence in 1897 there were 225 children in five levels. By 1901 there were only 196, but 241 children were studying German in 1905. In 1911 it was reduced to 157, and in August 1914 there were only 120. The situation in Manchester was similar. In 1897 there were 164 students of German; in 1903 there were 174, and in 1912 only 120.47 The number of students attending represented about one-sixth of the German children in the cities. In addition, non-Germans sometimes attended the classes, 48 and there is no way to determine their number. With so few students learning German, it was impossible to maintain the language.

The teaching of German in the public schools also provided a key test for language sentiment. At the start of the 1903 school year, it was announced that a teacher of German and Latin had been appointed by the school board. The teacher, Westphalian-born August Sonntag, had taught in a secondary school in Dortmund for ten years and had been in the United states for seven years. The first three he was employed as a private tutor and the last four as the teacher of the German School in Lawrence. German would continue to be taught in the Lawrence High School through World War I and after. 49 Apparently, German was never introduced to the curriculum of the Manchester High School.

Despite the introduction of German into the Lawrence high school, the larger language debate continued through this period, 50 and with good reason. Language maintenance is 
considered an indicator ethnicity rather than of assimilation. When large numbers of speakers of a particular language are present, one could assume that it would continue as was often the case of German in the large cities of the mid-west. An isolated group in a rural setting such as the Germans on the prairies of the Midwest or southern Brazil often maintains its language. Conversely, a small isolated group existing in a pluralistic setting, such as Manchester or Lawrence, could be expected to lose its language quickly. Despite such factors, the small group may be able to maintain its language, because its smallness makes it easier for its leaders, who are personally known, to influence its members. This would be somewhat of a factor in Manchester and Lawrence. However, the fact of being overwhelmed by the larger community and the necessity to work and do business would lead to a breakdown of the language. 51 That it lasted as long as it did probably had more to do with the placement of the generations rather than the efforts of the Anzeiger und Post, the clubs, churches or schools. That is, a number of young adults emigrated in the 1880 s and remained influential in the community until the 1930s; their children had attended primary schooi in Germany and, obviously, could speak German. 52

In the early 1900s, German-Americans began to feel especially proud and called attention to their perceived special qualities. To some historians, this meant that German-Americans were self-consciously aware of their 
slipping importance. 53 At this time, the German-American and his special attributes were a recurring theme in the pages of the Anzeiger und Post. This was a case of looking backward to Germany and forward to America at the same time.

If two poems were not enough to sing the praises of German-Americans, a reprint from Munsey's Magazine was enough to stir the pride. Munsey's reported that "when a GermanAmerican does something he does it right." The "worth of the Germans was massive."54 German art and music were considered superb. Its conclusion was that the United states was better because of the German immigrants. Not only would this make the reader feel proud, but his special attributes were recognized by the English language press. In the Deutsch Amerikanische Hymne, the first verse indicates that Germans will not return to the homeland but ends with a "hail Germania." In the second verse it speaks of the "homeland of my children" and ends with a "hail columbia." The third verse contains the often expressed German-American idea:

Germania, we honor you

always as a Mother

But to you, Columbia, you the bride, we belong 55

This theme was repeated on several occasions including the 1908 Lawrence German Day parade with a float containing "Germania" and "Columbia."56 The German American could be proud of his heritage and proud of his hard work and contributions to his adopted land.

Local German-American pride soon became 
institutionalized, more public, and broader in scope. The German-Americans in Manchester and Lawrence, although not isolated from other German-Americans, were about to become more involved in national German-American affairs. Those who were reading the Anzeiger und post were getting heavy doses of German-American pride. Those who belonged to clubs could be involved in New-England-wide events. Some, such as a group of Lawrence Turners, even attended a national competition in Philadelphia. 57 Manchester and Lawrence were about to become involved with the Deutsch-Americanische Nationalbund and the regional branch the Neu England Staatenbund or "New England States Alliance." The Alliance would come to Lawrence earlier than Manchester, and the activities would be more elaborate in Lawrence.

The idea of forming a federation of all German-American organizations began to ccalesce around the turn of the century. At a meeting in Philadelphia in 1901, representatives from states with large German-American populations formed the German-American National Alliance. Dr. Charles J. Hexamer, the son of a distinguished FortyEighter and a prosperous civil engineer from Philadelphia, was elected president, a position he would hold until his death in 1917. The Alliance fostered German culture, protected Germans from nativist attacks, and encouraged Germans to gain American citizenship. In fact, only American citizens could be members. 58 It was to become "the largest organization of any single racial group in 
American history," ${ }^{59}$ claiming two million members in 1914.

The Alliance's influence came from existing GermanAmerican organizations. The Alliance itself was organized into city alliances (Stadtverbunde) and state alliances (Staatsverbonde), or in the case of New England, a regional alliance. The existing local Vereine made contributions to the city Alliance and portions of these funds were passed up to the state and national Alliances. This support was probably not sufficient and hence the Alliance was also subsidized by the brewery interests. The Alliance also attempted to obtain the cooperation of the Roman Catholic Central Verein, the only other large German-American national organization, but with limited success. In 1907 the Alliance obtained a Charter from Congress and also signed an agreement of cooperation with the Ancient order of Hibernians. Until then the Germans and the Irish had often been in conflict over ethnic and hierarchical issues within the Catholic Church, as well as other matters of labor issues and life styles. 60 The agreement pledged the two groups to oppose foreign entanglements, efforts to prohibit alcohol, and immigration restrictions. 61 Foreign entanglements was generally understood to mean closer American relations with England, the source of enmity for both the Irish and Germans.

Brewers financed the Alliance for its opposition to Prohibition, but support was widespread in the GermanAmerican community. The Alliance received: 
considerable help from the German-language Press, and...claimed every German-American newspaper as its mouthpiece. Among its officials it numbered a long list of editors whose columns were naturally favorable to its points of view. Its activities were always front page news, and long and sympathetic editorials often gave emphasis to its decisions. 62

This was certainly true in Lawrence. Editor Max E. Trumpold of the Anzeiger und Post was active in the Lawrence stadtbund and was a delegate to the Neu-England staatenbund. His newspaper prominently featured activities of the Alliance. The efforts of the Anzeiger und post brought the Alliance to Lawrence and Manchester.

The charter from Congress specified a cultural nonpolitical purpose for the Alliance. Prohibition became an important issue to Germans partially because it represented a Puritan or Nativistic attack on individual freedoms and also because the sale of beer funded most Vereine. In addition, the Alliance favored Germany during the European phase of World War I (1914-17). It was suspicious of Wilson's neutrality and favored unsuccessful presidential candidate Charles Evans Hughes. These political activities brought the Alliance to the attention of Congress, which, after lengthy hearings, voted to revoke the charter in 1918. Anticipating the action of Congress, the Alliance had already dissolved itself. 63 In its better days the Alliance was a factor in the life of German-Americans in Lawrence and Manchester.

The first notice taken of the Alliance did not appear until November, 1905. It would probably be reasonable that an organization formed late in 1901, and most active in the 
states with large German-American populations, would not be noticed in Lawrence until 1905. In an editorial "regarding the purpose of the German-American National Alliance", the "Anzeiger und Post, supported joining the Alliance. Vereine in Boston and other cities had already joined. Thus Vereine und Logen in Lawrence should immediately join. The Alliance could "do much for the Deutschtum of this region." Furthermore:

The German-American is a special person.... He is joined from the mixed-product of the best of Amerikanerthum with the best from Deutschthum. He gets his spiritual nourishment from two sources the American and the German. It can be freely said that the German-American in all manners is an American.... The German-American is a principled person... The practical side of America and the idealistic side of the German are united in the German-American.... No one will fault us if we wish to pass our mother tongue on to our children and children's children... if we wish our children to learn German in school... and to develop their bodies through gymnastics. The National Alliance has these and many other valuable goals raised upon its flag.... Among the goals of the Alliance are: improving the reputation of Germans in the U.S.; maintaining the right of German immigration; preserving the peace; maintaining and spreading the German language, and assisting the German theater; and to expand the research and knowledge of German history.

The Alliance is politically neutral [and]... chartered by Congress... but [it opposes such things] as the immigration reading test, and blue laws.... One has the opportunity through the formation of a city alliance to assist. 64

Editorial support was followed up by action on the part of the leaders of other Vereine in Lawrence. Clearly, licensing and other forms of control of drinking were the relevant issues in both Lawrence and Manchester. Any 
organization which could lend clout to this fight was undoubtedly welcomed.

During the early summer of 1906, the Neu-England staaten Bund as a member of the Deutsch-Amerikanischen National-Bund organized at a meeting in the Boston Turnverein. Attending were Vereine from Webster (3), Easthampton, Boston (10), Lawrence (8), Clinton (4), Roxbury, West Roxbury, Boylston, South Boston, Chelsea, Fitchburg, Springfield, Taunton, Worcester, pawtucket, R.I., Providence, R.I., and Manchester, N.H. Representing the Harugari Association of Lawrence was M.E. Trumpold. The meeting was led by Professor Goebel of Harvard University, and the next meeting was scheduled for Lawrence. 65

Manchester, as a smaller German community and lacking the active involvement of the local editor, may have been at a disadvantage in forming a section of the Alliance. Manchester readers, of course, could follow the stories on the Alliance on the front-page and other pages of the paper. The Manchester correspondent reported on a speech by a Carl Eberhard about the Alliance. He judged it "necessary for the Germans of [Manchester] to become involved."66 The theme was repeated a few months later by the Manchester correspondent who cited the locally prominent lawyer Adolph wagner as supporting the Alliance. 67

In late spring 1907, the New England states Alliance met in Lawrence, hosted in the Turn Halle. The event naturally resulted in heightened press for the local, regional, and 
national branches of the Alliance. A few weeks before the meeting a front-page article reiterated the importance and value of the Alliance, especially the state and local sections. Germans in Lawrence needed a city organization to counter those "who believed in Temperance and in quiet sundays."68 Thirty Vereine from the following cities, Boston (5), Roxbury, Boylston, Chelsea, clinton (4), Greenfield, Lawrence (7), Malden, Manchester, Pawtucket, and Webster (3) attended the meeting. Manchester was represented by a new organization the Deutsch-Amerikanisches Centralbund, led by Hermann Rodelsperger, the local justice of the peace and insurance broker. Max E. Trumpold, representing the Lawrence Harugari Association, was elected secretary of the meeting. He also presented to the states Alliance a petition from the Lawrence Vereine protesting activities of the Immigration League and urging opposition to the restrictive immigration bill then being considered in congress. The members asked Congressman Butler Ames to insert into the Congressional Record the petition of the New England Alliance regarding the bill. The group determined that local Vereine should list books in German in their city libraries and to lobby for more German books to be added to the collections. 69

The local and regional enthusiasm must have impressed the national leader of the Alliance. The 1910 German Day celebrations in Lawrence featured Dr. Hexamer as the guest of honor. 70 at the next national executive committee meeting in washington, D.C. four representatives from 
Lawrence, including editor Trumpold, attended. By this time Max Trumpold was the leader of the Lawrence stadtbund. 71 In September 1912, Dr. Hexamer visited Manchester to celebrate Manchester's German Day and to assist in the founding of the New Hampshire State Alliance. From all appearances this alliance was based in Manchester, but delegates were elected from Dover, Berlin, Nasinua and Concord. Dr. Hexamer's speech reiterated the themes of German-American history and loyalty to German language and culture combined with loyalty to America. 72

Part and parcel of the German-American Alliance was the German Day celebration of German-American pride, which was set in october to commemorate the landing of the first Germans in Philadelphia in 1683. The Alliance fostered the celebration of German Day by the local organizations with hopes of establishing a German Day holiday. 73

The Germans of Manchester and Lawrence celebrated German Day, sometimes in grand style. In 1908, Lawrence Germans staged an elaborate German Day celebration, bringing together clubs, lodges, schools, and church organizations. There were musical events and dances. The parade on Saturday consisted of four divisions, including all of the German organizations, some clubs and German bands from Manchester, and German Catholic, Presbyterian, and Methodist groups. The parade began in the German district, but followed a route which took it to the common, passing in review at city hall, then along Essex Street, and back to the Lyra Hall. 74 
Such an event was bound to attract viewers of all nationalities. In fact, the Anzeiger und Post, reported that many "American businessmen were interested in German-Day festivities," and "many Americans shouted greetings to the marchers."75 Featuring a float containing "Germania, Columbia, Peace, Construction, Industry, Labor, and Commerce," this event brought together the diverse elements of the German community in Lawrence, increased pride in Deutschtum, and received favorable review from the non-German citizens. 76 Lawrence continued its Giman day celebrations, bringing in the president of the German American Alliance in 1910. The national president of the woman's branch of the German National Alliance was the guest of honor at 1911 German-Day in Lawrence ${ }^{77}$

Meanwhile, Germans in Manchester began to look to its neighbors in Lawrence for inspiration in planning such events in their city. They were able to attract Dr. Hexamer to Manchester in 1912 in conjunction with the German-Day activities. In Manchester, German-Day, 1913 was a more subdued affair. It featured a short parade on the West side between the Vereine. The event featured orchestra, singing performances, and dances on both Friday and saturday nights in the Turn-Halle. On Saturday there was a large Volksfest in the Turnhallengarten. The parade through the streets of West Manchester would likely have attracted the attention of non-German residents of the area. 78

The Germans of Lawrence and Manchester could certainly 
feel themselves to have been part of the larger Deutschtum in the United states. Their newspaper contained materials taken from other German-American papers, selected to reflect the views of the editors of course. But, the readers may have found that the views were not much different than those of the editors. Led, and, perhaps, prodded by the editor, they became involved with the national Alliance. The involvement of the small German populations in Lawrence and Manchester (and in fact those in other New England cities) in the Alliance was not expected. However, it appears that the German-American National Alliance considered cities with small German populations such as Lawrence and Manchester important in its attempt to preserve Deutschtum and to weld and wield a German-American block.

The Germans of Manchester and Lawrence were not entirely confined to Deutschtum and Vereinsleben, since some became involved in local politics. However, Germans never challenged the political order in both cities. The German vote, while not to be ignored, was not sufficient to be the swing vote in either city. In Lawrence, political battles were among the Irish and between the Irish and AngloAmericans. Factions loyal to the Breens or Sweeneys fought over control of city hall. The Irish could unite, however, to beat Anglo-American attempts to gerrymander the wards so that all the Irish were in one ward. 79 Meanwhile Germans were contented to gaining a seat on the city council from Ward 1 or in obtaining other elected or appointed offices. For 
instance, in 1890 Emil stiegler served on the council from Ward $I$ and in 1900 he was one of the members of the Board of Health. 80 In the 1890s, August stiegler, the local store owner and brewer was a candidate for office. In 1899, Hugo Dick, editor of the Anzeiger und Post, served one term on city council 81 The Germans in Lawrence tended to vote Republican, but in 1904 they voted for Democratic Mayor Lynch, whom they considered reasonable on the issue of licenses for saloons and clubs. ${ }^{82}$ Germans in Manchester also became involved in politics, but neither did they challenge those who controlled the city. Although Anglo-Americans served as mayors, the Irish controlled the city council and police force. Germans often won one or two places on the city council and to the state legislature. Germans in Manchester also favored the Republican party, but a number were active in the Democratic party. Community leaders such as Olzendam, or mill supervisors such as J. Adam Graf, often ran for office on the city council or legislature. 83 Among those who served on the Manchester City Council were Republican Adolph Wagner, the local lawyer, and Democrat Hermann Rodelsperger, the local Justice of the Peace. 84 Every year at election time, the Anzeiger und Post, reported on the political ward meetings, prominently listed the German candidates for office. 85 It also carried political advertisements from non-German candidates. The political news and advertisements indicated that Germans had become American citizens. Obtaining citizenship and voting in 
elections started the assimilation process.

soon, events larger than local ward politics would command the attention of Germans. In 1912, the attention of everyone in Lawrence turned to the strike in the mills. The strike brought into focus a number of issues for the Anzeiger und Post and the Germans of Lawrence. Their attitudes toward labor and management during the strike indicated an awareness of larger issues and American attitudes.

The 1912 strike was probably the defining moment for the city of Lawrence, and German workers remained pretty much on the sidelines. At the start of the strike only those Germans with socialist leanings joined the strikers. Most of the others in the more skilled positions in the mills did not join the strike until it was more than half over. Few Germans joined the I.W.W. Among immigrant groups, the Italians and Poles led the strike 86

on the other hand, Germans generously contributed to the strike funds. It is unclear who organized the German fundraising, but the Anzeiger und Post prominently featured the fund and listed the contributors. Individuals solicited contributions, and the Anzeiger und post reported the contributors' Liste, of which there were many. Vereine from Fitchburg, Adams, clinton, Springfield, West Roxbury, Taunton, Holyoke, and Manchester (Turnverein and Harugariklub), contributed. The New Jersey Volkszeitung contributed over one thousand dollars to the fund, which was included in the $\$ 2,557$ paid out in March. 87 
A paper such as the Anzeiger und post had to depend both on the German business owners and the German laborers of the city. The former bought advertisements and had their printing done at the paper; the latter provided the necessary subscribers. The owner-editors probably tended to identify with the other business owners. However, since 1899 the newspaper had displayed the "union label." It also took a sympathetic stand toward the strikers:

The factory owners must think about how the industry has for so many years had a protective tariff, which it constantly maintains is absolutely necessary... Why they do not pay the workers a decent wage.

It was the opinion of the paper that the wages paid were not enough for a family to live on. 89

The ethnic background of the strikers was also of concern to the Anzeiger und Post. The paper clearly blamed Mr. Wood, president of the American Woolen Company, for obtaining the:

cheapest labor from southern Europe through agents and newspaper advertisements.... [Initially] the poor people of southern Europe thought five or six dollars [a week] was a big wage... but soon found out differently here.... [They were] at the lowest levels of the textile jobs and were not earning enough for a family.... The worker in America cannot, and should not, become like the 'pauper' worker in Europe. Is it not possible to pay a decent wage to the lowest workers, so that women and children can eat? ${ }^{9}$

The paper felt that it had not been necessary for Mr. Wood to have imported the cheap labor from southern and eastern Europe. It called upon the President and Congress to 
investigate the woolen industry 91

The editors generally favored the cause of the strikers and may have been slightly ahead of public opinion. It is probable that most of the workers of Lawrence came to favor the cause of the strikers, as, it turned out, did many Americans. Congress did investigate the woolen manufacturers, and the President's wife was conspicuous in her attendance. If the inzeiger und post and eventually the local Germans were on the right side of this issue, international events were going to challenge and test them. 
${ }^{1}$ Berquist, "Illusions and Realities," 3-6.

2 Ibid., 2-5.

3 Ibid. , 4-5.

${ }^{4}$ Anzeiger und post, October 7, 1929. Max E Trumpold lived from 1861-1929, or 68 years. Basing some assumptions on this life span it is possible that the second and third generations could be involved in the vereine well into the twentith century. For instance a life span of 65 years.

\begin{tabular}{|c|c|c|c|c|c|}
\hline $\begin{array}{l}\text { generation } \\
\text { lst } \\
\text { (age) }\end{array}$ & $\begin{array}{l}\text { birth } \\
1864\end{array}$ & $\begin{array}{l}\text { immig } \\
1882 \\
(18)\end{array}$ & $\begin{array}{l}\text { marriage } \\
1887 \\
(25)\end{array}$ & $\begin{array}{r}\text { Iirst } \\
\text { child } \\
1888 \\
(26)\end{array}$ & $\begin{array}{l}\text { death } \\
1929 \\
(65)\end{array}$ \\
\hline 2nd & 1888 & & $\begin{array}{l}1913 \\
(25)\end{array}$ & $\begin{array}{l}1914 \\
(26)\end{array}$ & $\begin{array}{l}1953 \\
(65)\end{array}$ \\
\hline $3 \mathrm{rd}$ & 1914 & & $\begin{array}{l}1939 \\
(25)\end{array}$ & $\begin{array}{l}1940 \\
(26)\end{array}$ & $\begin{array}{l}1979 \\
(65)\end{array}$ \\
\hline
\end{tabular}

Therefore it is possible for the second generation to be leading the societies into the 1940 s and the third into the 1970s. Second or third born could continue the German activities to an even later date, but may have been more Americanized. Several of the individuals interviewed by the author confirmed grandparents from Germany. The continuation of Vereinsleben after World War I and into the 1940 s will be discussed in subsequent chapters.

${ }^{5}$ Hans W. Gatzke, Germany and the United States: "A Special Relationship?" (Cambridge, Harvard University Press, 1980), p. 32 .

${ }^{6}$ For example advertisements in the Anzeiger und Post, for May 5, 1908 include the following posibilities for the following weekend in Lawrence: Gemeinschaftlicher Ausflug of the Lyra Halle, concert and Ball in the Turn-Halle, Grosser Preis-skat $u$. Wendisch mit 'Smoker' in the Harugari-halle, Grosses Orchester-Concert in the Turn-Halle, Grosser Ball of the Bayerischen Frauenverein in der Bayern Halle, Tanz-Music in the Turn Halle. 
7 The lists of Verein officers in the Anzeiger und Post and club and officer lists in Directories for Manchester and Lawrence the officers were compared with occupational listings in the Directories of Manchester, Lawrence, and Methuen. Over 85 of the officers were of the skilled working classes, i.e. weaver, loom fixer, etc. or of the business classes, the grocers, restaurant owners, undertakers, sauasage makers, insurance sales brokers, etc. The remainder were of the semi-skilled working class or unspecified in the mills, and were normally associated with the laboring organizations such as the Worker sick Benefit clubs, labor unions, socialist parties or strictly worker clubs.

${ }^{8}$ Lawrence Directory, 1900, 1905, 1910, 1915, Manchester Directory, 1900, 1905, 1910, 1915, and issues of the Anzeiger und post.

Clubs in Lawrence included: Brauer Union: German Cooperative Association; German American Alliance; German School Society; German Hospital Free Bed Society; Ruth Society, Arbeiter Mannerchor: German old Peoples Home: Turnvereir, Turner's sick Benefit Society, Turner's singing Section, Tigers of the Turnverein; East Methuen Hose Comany; Society for the Natural Treatment in Sickness; Lawrence Harugari Association, Schiller-Freiheit Lodge of the Harugari, Freiheit Sisters Society, Women's Death Benefit Fund of Schiller Lodge, Sisters Society Freheit Lodge, Harugari, Lawrence [chapter] of the Harugari; Arion Singing Society; Hermann's Hall Association, Harmonie Lodge, Hermanns Sons, Brunhilda Lodge, Hermanns Sons Sister's Society: Lyra Singing Society; Society Junger Cherusker; Alsatian sick Benefit Society; Neunzehner Glub; Glocke Society; Textile Arbeiter Verband; General Sick Relief Society; Bavarian Reading and Progressive Society, Sisters Society of Bav. Reading, and Progressive, Bavarian $R$ \& P Sick Benefit Fund; Liederkranz Singing Society: German Central Association, Sisters Society German Central Association; Socialist Workingmens Society; Sons of Zion; Workingmans Sick and Death Benefit Fund U.S.A; Workingmans Sick Relief Societies: Eintracht Singing Society; Voerwarts Singing Society; German Cremation Society, Concordia Shooting club; German Spirualist Society (Wahrheits Sucher): Society for the Cultivation of Honey Bee; Radfahrer (bicycle) club. In Manchester there were the: Turnverein, Turn Sisters; Turnverein Germania; Harugari Society, Barbarossa (womens) Society of Harugari; Mannerchor singing Society; Workingmens Sick Relief Association Womens Branch A.K.U.V.: Nature Cure Society: Beethoven Mannerchor; Schiller Lodge Hermanns Sons, Martha Washington (womens) lodge Hermanns Sons; Bavarian Benefit Society. German School Society; Consum or Cooperative Club: Radfahrer (bicycle) club. 
${ }^{9}$ Anzeiger und Post "Das neue deutsche Altenheim," February 22, 1913. The other city German mututual benefit association was the Free Bed Society, mentioned in Chapter $v$.

10 Tolzman, cincinnati Gemans after the Great War, 12. olsen St. Louis Germans 135. For population data and sources see note 12 Chapter II, above. Tolzmann lists 112 clubs, 12 singing, 12 trade, 59 mutual aid, 3 shooting, 3 Turnverein, 13 cultural, 7 charitable, 3 central. Olsen lists over 300 and does not specify exact numbers or types, or if women's or children's sections are included. This calcualtion is therefore rough. Also, the German unions were not included in the calculations for Lawrence or Manchester. Also women's lodges or subsections of the main club are not included: and church clubs are excluded. Population figures are for 1910 . below. Comparisonsof the Vereine in the various cities is given

CINCINNATI

German born

German parentage
38,219

136,807
Vereine

112

112 persons per verein

1,221

ST. LOUIS

German born

German parentage

58,781

199,182

1,225

3,423

2,301

7,225
300

300

12

12

102

285
195

663

\section{LAWRENCE}

German born

German parentage

Lawrence and Manchester with unions and the women's sections and the sub-clubs or benefit/aid sections of the main clubs added.

MANCHESTER

German born

German parentage

1,225

16

16

77

3,423

214

IAWRENCE

German born

2,301

7,225

49

German parentage

49

147

${ }^{11}$ club amenities compiled from descriptions of several clubs in the 25th Anniversary issue of the Anzeiger und post, February 8, 1908; plus articles on July 27, 1889, "Neu Lyra Halle Lawrence;" April 19, 1890, "Barbarossa Lodge, 
Manchester;" October 4, 1890, "25th. Lawrence Turnverein;" March 6, 1897, "25th Manchester Turn Verein;" May 1, 1897, "Beethoven Hall, Lawrence;" January 23, 1908, "25th. Manchester A.K.U.V."

${ }^{12}$ Anzeiger und Post, March 24, 1900. At the sunger Abend the singing societies included: Lyra, Arion, Glocke, Mozart Munnerchor. Turner Gesangsektion. Vorwlirts, Liederkranz, and Eintracht.

13 Anzeiger und Post, February 10, 1916. Similar activities were held in 1913 (March 1, 1913) Central Halle Costum Ball and Lumpen Ball, Benefit Perfermance, Kostum Ball in Hermanns Hall, Bayern Hall, Lumpen Ball and Kinder Maskenscherz, Lyra Hall a performance for the birthday of Wagner, and the Harugari society was holding a "great fair."

${ }^{14}$ Anzeiger und Post, September 7, 1901, Das Sangerfest: December 20, 1903 "Beethoven-Feier" by the Beethoven Mannerchor: October 26, 1903., Stiftungsfest of the A.K.U.V. December 26, 1903; (advertisement) on Sylvester Abhend, Grosse Damen-Ball in Harugari-Halle; May 1, 1904 "Fair des Schulvereins; November 12, Minstrel show in Turn-halle.

${ }^{15}$ Roy Rosenzweis, Eight Hours for What We Will: Workers and Leisure in an Industrial city, 1970-1920. (Cambridge and New York, Cambridge University Press, 1985).

${ }^{16}$ Mary Jane Cory "The Role of German Singing Societies in Nineteenth-century America," in E. Allen Mccormack, Germans in America, pp. 155-168. The festival halls were built in st. Louis, Cincinnati, Philadelphia, and Louisville.

\section{Anzeiger und post, September 7, 1901, "Das} sangerfest." Other singing societies existed in North Adams, Providence, East Cambridge, Turners Falls, South Boston, Worcester, and Holyoke, see Anzeiger und Post, June 2, 1900, "Neu-England Staats Sangerfestung in Clinton, Ma."

\section{${ }^{18}$ Anzeiger und Post, July 2,1904 Das Turnfest; July 9, 1904, "Bezirksturnfest."}

${ }^{19}$ Constance Green, Holyoke Massachusetts: $\underline{A}$ Case History of the Industrial Revolution in America, (New York, Archon Books, 1968), pp. 19-65, 81-83, 73-74.

${ }^{20}$ Green Holyoke, pp. 74-74, 106-107. Gerhard Wiesinger, "Die deutsche Einwandererkolonie von Holyoke, Massachusetts, 1865-1920" PhD Diss. München, 1990. In Ward 3 the concentration was $88 \%$ the highest in any massachusetts city. See also, Marianne Pedulla, "Labor in a City of Immigrants: Holyoke 1882-1888," Historical Journal of Massachusetts. 13 $(1985), 147-61$ 
See Chapter I footnote 12 for population figures in 1900: City German born

Manchester $\quad 1,124$

Lawrence $\quad 2,465$

Holyoke $\quad 1,602$

German parentage

German-American

2,146

3,270

4,705

7,170

3,018

4,620

${ }^{21}$ Raymond L. Sickinger and John $\mathrm{K}$ Pirmeau, The Germans in Rhode Island: Pride and Perservance, 1850-1985,

(Providence, The Rhode Island Heritage Commission, 1985) pp. $4,5,6,14,17,18,20-22,25-27$. It is estimated that in 1860 there wee only about 80 Germans in Providence. By 1910 there were about 13,200 Germans in Rhode Island, 6,700 of whom lived in Providence.

${ }^{22}$ Ibid., pp. 28-35.

${ }^{23}$ Ibid. , pp. 36-47. The famous speidel corporation is not considered, since it was established as a branch operation of a German company.

${ }^{24}$ See Chapter I, footnote 12. See also Frederick A. Bushee, Ethnic Factors in the population of Boston, (New York, Arno Press, 1970, originally published 1903), p. 1 . Bushee gives figures of 10,533 German born and German parentage of 21,618. Faust, German Element, Vol I. p. 580 gives the German parentage as 25,119. Also Oscar Handlin, Boston's Immigrants, 1790-1880, (Cambridge, Belknap Press of Harvard University, 1991) p. 243. The German Population in 1850 in Boston (and Roxbury) was 1,777; in 1860, 4,4831; in 1865 it was 5,$434 ; 3790$, and in 1880 it was 7,396 . The growth of the German population in Boston also came at the end of the nineteenth century.

Among the reasons that Boston's Germans have not been studied could be the fact that the Germans have been submerged by the number of Irish and issues surrounding the Irish in Boston or the fact that no one German-language newspaper lasted for any considerable length of time or were perserved for any signifiant period.

${ }^{25}$ See Arndt and 01sen, German Americn Newspapers, pp. 201 to 206 for a list of newspapers in Boston and the available years and locations. See also Karl Arndt "Newspapers and Periodicals" in Germans in Boston, (Goethe Society of New England, Boston, 1981), pp. 70-72.

${ }^{26}$ Bushee, Ethnic Factors in Boston, pp. 11, 12; Bushee Ethnic Factors in Boston, pp. 63-65, under personal service many Germans were listed as barbers, pp. 67; 72. Bushee, a nativist, gives other figures which preset the German

immigrant in favorable light compared to other groups. The amount of money per capita brought by a German was $\$ 30$ compared to $\$ 40$ for English and $\$ 9$ for Jews and Southern 
Italians, p. 14. The illiteracy rate was Scandinavians .62, Irish 3.12, Germans 3.98, Southern Italians 49.12, p. 19. Proportion naturalized 1900, Germany 85.20 , Holland 83.69, Ireland 83.22, Switzerland 76.47, Austria 66.04 Italy 36.41 , p. 122. Registered voters percent of males 1896, Ireland 48.96, Germany 45.6, Switzerland 45.6, Holland 44.1, Austria 41.8 , Italy 10.4, p. 124.

27 Bushee, Ethnic Factors in Boston, pp 67, 72. Bushee Ethnic Factors in Boston, 63-65, under personal service many Germans were listed as barbers. See also Stephan Thernstrom, The other Bostonians: Poverty and progress in the American Metropolis, 1880-1970, (Cambridge: Harvard University Press, 1973).

${ }^{28}$ see also Handlin, Boston's Immigrants on the type of manufacturing and commerce in Boston and occupational data from around mid-century.

29 Anzeiger und Post, June, 2, 1900. Ordens der Harugari, Grosslogen Massachusetts Buch, 1929-30, p. 2. See Elizabeth von den Benken, "The Ladies Aid Society and the Deutsches Altenheim, and Carl J. Ludwig, "The Boylston Schul Verein" in Goethe Society Germans in Boston, 84-85 and 87-88. The Deutsches Altenheim and the Boylston Schul Verein continue to exist.

30 For the continuation of the Turners see, American Turners Annual Report, 1936-37, p 42 which listed societies in Boston, Roxbury, Holyoke (2), Lawrence, clinton, Springfield, Fitchburg, Malden, Adams, pittsfield, Providence, Manchester, and Jamaica Plain. See also The American Turners, Directory of National Council, District Councils, and Society Leaders, 1985, which lists for New England, 44-52, societies in Adams, clinton, Fitchburg, Holyoke, Profidence, Springdale (Holyoke), and Springfield. Such secondary works as Howard $M$ Gitelman, Workingmen of Waltham: Mobility in American Urban Industrial Development, 1850-1890, (Baltimore, Johns Hopkins University Press, 1974) and Alan Dawley, Class and Community: The Industrial Revolution in Lynn, (Cambridge: Harvard University Press, 1976) do not mention Germans or German workers.

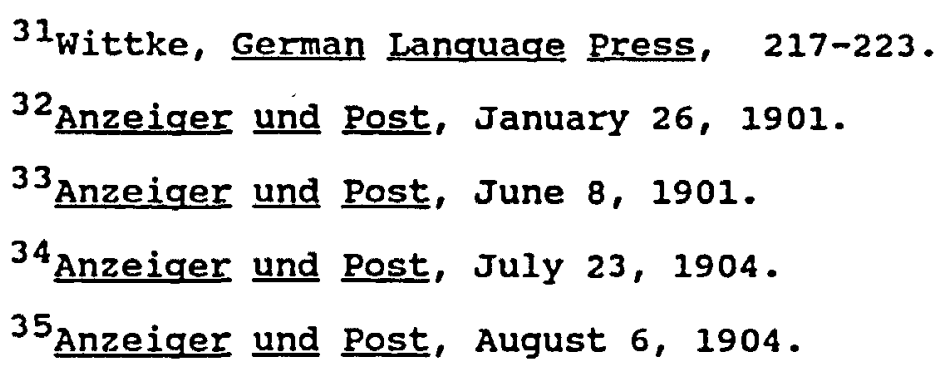


36 Anzeiger und Post, August 6, 1904.

${ }^{37}$ Anzeiger und Post, September 4, 1904 reprinted from the Logan (Utah) Post:

${ }^{38}$ Anzeiger und Post, September 14, 1904, the local representative, and probable writer of the column, was H.H. Eberlin.

${ }^{39}$ Anzeiger und Post, october 7, 1911, death notice of Hermann Heinrich Eberlin. Born in Baden, Eberlin spoke German, English, and French, had been teacher at the Manchester German school, a private language tutor, and the representative of Anzeiger und Post in Manchester since 1903.

40 Anzeiger und Post, December 17, 1904.

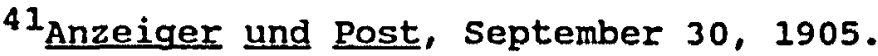

42 Anzeiger und Post, October 7, 1905. The newspaper used the English term "dutch."

${ }^{43}$ Anzeiger und Post, February $24,1906$.

44 Anzeiger und Post, November 2, 1907.

45 Anzeiger und Post, June $27,1908$.

46 Anzeiger und Post, January 28, 1905.

${ }^{47}$ All figures from the Anzeiger und Post. The reports from Manchester are more irregular than in Lawrence.

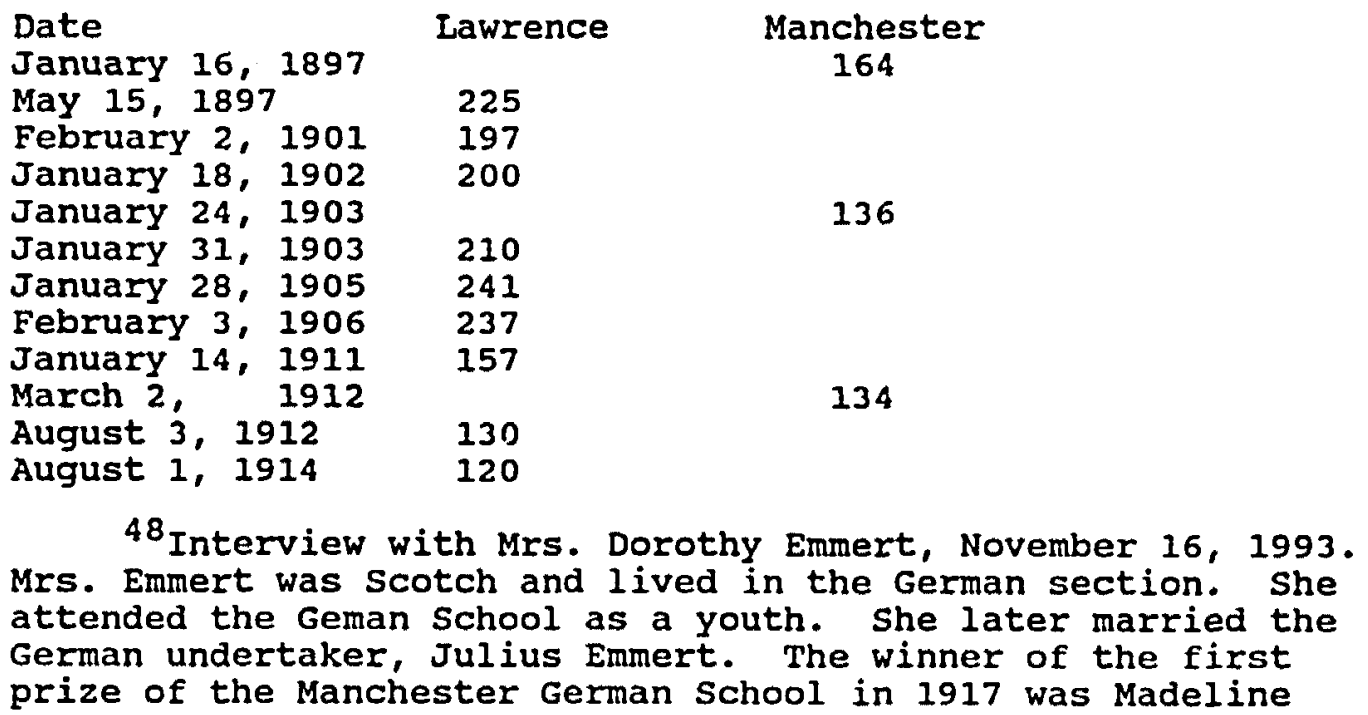


Flaherty, Anzeiger und Post, January 27, 1917. Interview with Julius W. Emmert, March 17, 1994. He remebers several Irish and Italian fellow students in the German school in the late 1930 s and early 1940 s.

${ }^{49}$ Anzeiger und post, September 12, 1903.

${ }^{50}$ The issue is addressed in the Anzeiger und Post August 1, 1906, October 12, 1907, November 9, 1907, March 14, 1908, May 2, 1908, May 9, 1908, July 18, 1908, April 9,1910, Apri1 1, 1911, April 22, 1911, August 5, 1911, January 30, 1912, January 14, 1914 to list just a few.

${ }^{51}$ see Heinz Kloss, "German-American Language Maintenance Efforts," in Joshua A. Fishman, ed. Lanquage Loyalty in the United States, (The Hague, Mouton \& Co, 1966), 206-252 for a discussion of language maintaince, the factors, and some of the isolated German communities. See also Joshua A. Fishman, "Language Maintainence" in Encyclopedia of Ethnic Groups, 629-638. For other information on isolated communities, see Kamphoefner, The Westphalians; Frederick Luebke, Germans in Brazil: A Comparative History of Cultural Conflict During World War I. (Baton Rouge, Louisiana State University Press, 1978). Kathleen Niels Conzen, "Making their Own America: Assimilation Theory and the German Peasant pioneer." Annual Lecture, Number 3 of the German Historical Institute Washington D,C. 1990

${ }^{52}$ see above note 4 regarding the generations in Lawrence. Interview with Jay Emmert, November 16, 1993. Julius Emmert emigrated at the age of eight in 1880 . He insisted on German at the dinner table. He died in 1956.

53 Berquist, "IIlusions and Realities," 1-14. Yox, Decline in Buffalo," 199-202.

${ }^{54}$ Anzeiger und Post, poems October 20, 1904, "Um die Deutsch Amerikaner" and May 5, 1905, "Die DeutschAmerikaner"; March 3, 1906, contained excerpts from Herbert N. Casson, "The Germans in America," Munsey's Magazine, 34 (March, 1906), 694-707.

55 Anzeiger und Post, March 2, 1907, Germana, wir ehren

Dich stets als Mutter traut.

Dir aber wir gehbren,

Columbia, Du Braut.

56 Anzeiger und Post, October 3, 1908, German Day Parade; and August, 26, 1916, for the German Week activities in 1916 . 
57 Anzeiger und post, June 9, 1900. Among the Turners from Lawrence attending were otto Dick, son of the local contractor and nephew of the co-owner of the paper, and Fred Schonland, son of the sausage manufacturer.

${ }^{58}$ clifton J. Child, The German-Americans in politics, (New York, Arno Press, 1970), pp. 2, 3, 4, 5.

59 Ibid. , p. 4.

${ }^{60}$ See Barry, Catholic Church and German Americans; Philip Gleason. The Conservative Reformers: German-American Catholics and the Social order, (South Bend, Dame, IN, University of Notre Dame Press, 1968): and Carl Wittke, The Irish in Amrica (Baton Rouge: Louisiana State University Press, 1956), pp. 186-187. 8-9.

${ }^{61}$ Child, German-Americans in politics, pp. 5, 14-15, 6,

${ }^{62}$ Ibid., p. 5.

${ }^{63}$ Ibid., p. 173, see also pp. 64-154, passim.

${ }^{64}$ Anzeiger und Post, November 18, 1905.

${ }^{65}$ Anzeiger und post, June 9, 1906. The report took up a column and a half, mainly listing the attendees. Herr professor Goebel was not otherwise identified.

66 Anzeiger und post, June 2, 1906. Mr. Eberhard, who later became president of the New England Alliance, is not identified. Manchester did send a representative to the organizing meeting in Boston.

67 Anzeiger un Post, September 9, 1906. Carl Eberhard spoke at the Turnhali about the Bund. Adolph Wagner was a local attorney, councilman, and state representative.

68 Anzeiger und Post, May 18, 1907.

${ }^{69}$ Anzeiger und Post, June 1, 1907. In 1909 the New England Regionl Allience met in Manchester, Anzeiger und Post, May 29, 1909.

${ }^{70}$ Anzeiger und Post, September 24, and October 8 , and October 15,1910 .

${ }^{71}$ Anzeiger und Post, January 14, 1911, meeting held December 7, 1910. Attending from Lawrence M.E. Trumpold, Hermann Grunwald, Carl Herzog, Ernst Hindermann, and Paul Weidner. See Anzeiger und Post, March 11, 1911 regarding Trumpold as leader in Lawrence. 
${ }^{72}$ Anzeiger und Post, September 14, 1912.

${ }^{73}$ Anzeiger und Post, "Der Deutsche Tag und der DeutschAmerikanische National Bund," October 5, 1907. The date was set for october 6 , but was celebrated on the nearest weekend.

74 Anzeiger und Post, October 3, 1908. Some bands were listed with English titles including the Lawrence Military Band, Lawrence Brass Band, and Andover Brass Band. It is not clear whether these were German or non-German bands.

${ }^{75}$ Anzeiger und Post, October 3, 1908.

${ }^{76}$ Lawrence Eagle Tribune, September 28, 1908.

${ }^{77}$ Anzeiger und Post, October 14, 1911. Frau Emma J. Dornhoefer was welcomed to town by Max E. Trumpold.

${ }^{78}$ Anzeiger und Post, September 19, 1908 reports on the German Day in Lawrence. Anzeiger und Post, September 13 and 20, 1913, articles and advertisements placed by the committee give the events for Manchester's German-Day.

${ }^{79}$ Cole, Immigrant city, pp. 48-59.

${ }^{80}$ Lawrence Directory, 1890, 1905.

${ }^{81}$ Anzeiger und Post, January 18, 1919. Cole, Immigrant city, p. 45 .

${ }^{82}$ Anzeiger und Post, November 26, December 3, 10, 1904.

83. Anzeiger und Post, December 26, 1896. Manchester Directory, $1900,1905,1910$.

${ }^{84}$ Manchester Dirastory, 1895, 1900, 1905, 1910.

${ }^{85}$ Anzeiger und Post, December 1, 1900, December 3, 10, 1904. Also October 31, November 7, December 5, 12, 1908.

${ }^{86}$ Cole, Immigrant city, for Germans see p. 186 . Cole estimates that only 400 Germans joined the I.W.W. For his narrative on the strike see pp. 177-194. For the role of women and Italian and Polish immigrants see Ardis Cameron "Bread and Roses Revisited," 42-61. See also above Chapter IV. The other "old immigrant" group, the Irish, were also absent from active involment in the strike.

${ }^{87}$ Anzeiger und Post, March 23, 1912.

${ }^{88}$ Anzeiger und Post, January 20, 1912. 
${ }^{89}$ Anzeiger und Post, January $20,1912$.

90 Anzeiger und Post, January $27,1912$.

91 Anzeiger und post, January $27,1912$. 
CHAPTER VII

REALITIES, 1914-1920

WORLD WAR I, AND THE LOCAL SITUATION

Much that has been written about German-Americans argues that German-ness, (Deutschtum), German culture, and German ethnicity disappeared during World War I. Thus, the largest and most active of ethnic cultures in America vanished. The impact of this can be better understood, since at one time German culture was "pervasive in the United States, and "entwined in the fabric of American society....[T] Ge German influence in the country was up until 1917 as large, if not larger than, the Spanish-speaking influence of the 1980s."I This culture, it is often argued, completely disappeared with the war. ${ }^{2}$ Furthermore the shocks of World War I undermined the ethnic identity of German-Americans. ${ }^{3}$ As a result German language services in churches ended and German halls and restaurants closed, and German ethnicity became private and practiced only in the home. ${ }^{4}$ In short, according to these interpretations German-Americana did not survive the war. 5

A number of scholars also believe that World War I killed German culture even in cities with large numbers of German-Americans such as Chicago, Buffalo, st. Louis, and cincinnati. 6 If German culture somehow managed to survive 
the war, Prohibition gave it the coup de grace. Even in Denver, where Germans were influential politically and economically, World War I hysteria swept away Deutschtum.?

other historians argue that Deutschtum survived the war. In Baltimore the German-American clubs revived after the war, and prominent German-Americans assumed cultural leadership. However, they were reluctant to take public stands on issues relating to Germany. ${ }^{8}$ Another scholar believes that in Chicago, German Vereine had little difficulty in reestablishing themselves after the Armistice. 9 Chicago's German-American leaders, whose economic livelihood depended on it, were "determined not to allow their community to disappear."10 However, Chicago's Germans, unable to unite during the war, continued to remain divided by class, religion, and politics. Thus, they could not maintain an ethnic identity. 11 In cincinnati, Deutschtum not only survived the war but received new life after it when new immigrants formed new clubs and kept the German language alive. Pre-war leaders revived the major Vereine and turned their attention to fund-raising for Germany. Despite such successes, Cincinnati's Germans also practiced their culture in private. In addition, war hysteria became a cover to reduce their political power and, hence their status. 12

It will be shown that, unlike other cities and unlike the common perception, World War I did not destroy Deutschtum in Manchester and Lawrence. In fact local Vereinsleben continued through the war, even to the extent that a New 
England Turnfest was held in Lawrence in June 1918. After the war, local and New England wide public events resumed and continued through the 1920s and 1930s. World War I did have a profound effect by uniting the catholic and Protestant Germans with the Vereinsdeutschen for the first time. Also, the citizens of Manchester and Lawrence engaged in no mass anti-German hysteria.

For local German-Americans, as for most German-Americans in the United states, the war can be divided into several phases. At the start of the war, when the United states was still neutral, German-Americans and their organizations and newspapers rushed to defend the actions of Germany and to raise money for orphans and widows in Germany. The next phase centered around submarine warfare and the growing tensions between Germany and the United States. The GermanAmerican National Alliance spearheaded campaigns for neutrality and to elect Charles Evans Hughes in the 1916 Presidential election. The third phase was the unthinkable, war between the old and new homelands. Most German-Americans joined the "colors" and otherwise proved their loyalty. The end of the war brought concerns about the treatment of Germany during the negotiations, disappointment over the harsh terms of the treaty, and prohibition-induced problems for the clubs. Each phase of the war's impact on the GermanAmericans of Manchester and Lawrence must be considered. The guns had hardly fired their first round when the Anzeiger und post fired its first salvo at the "Anglo- 
American Press." On August 8, 1914 the paper commenced by condemning the "hate of the Anglo-American press."13 A week later, on August 15, the paper angrily reacted to the "AngloAmerican press which has begun its unashamed and hostile words toward Germans."14 There is no way to know whether these comments were those of the local editors or provided by some service. They should not have criticized the Lawrence newspapers which were balanced in their coverage at the outset of the war. It is more likely that they were referring to the national press. For instance, The New York Times branded Germany the aggressor and reported on August 3 that Belgium, Luxembourg, and Switzerland had been invaded by Germany, and that indiginities had been committed against Americans in Germany. 15

Manchester Germans, in an unsually early and organized action, took up the call of the paper. On August 22 the local correspondent reported: "the local Germans are about to protest against the false, libelous and hostile attacks by the Anglo-American press, which were recently pointed out in this newspaper."16 This quickly organized action was uncharacteristic of Manchester Germans who traditionally lagged behind Lawrence Germans in political matters. Adolf Wagner, president of the Manchester stadtverband of the German American National Alliance and a lawyer and local politician, and Hermann Rodelsperger, the broker, justice of the peace, and occasional political candidate organized the meeting. The involvement of these prominent Germans 
indicates the seriousness they attached to the issue, and the probability that they felt that there was no negative political fallout from the larger community for their actions.

Germans in Lawrence organized a more elaborate meeting for September 2. Invited as the main speaker was Harvard professor Hugo Munsterberg, an internationally renowned psychologist who had retained his German citizenship. Intensely devoted to justifying Germany's cause, Munsterberg entreated his audience to offer sympathetic understanding of the German cause and to act to keep the United States uninvolved and neutral. The Lawrence Telegram reported that a large and enthusiastic crowd attended the meeting. Both Pastor Lange of the Presbyterian Church, who had a brother in the German Army, and Pastor Peglow of the German M.E. church attended. The meeting adopted a resolution criticizing the Anglo-American Press. ${ }^{17}$

The Lawrence Telegraph not only reported on the event but joined local German citizens in criticizing war reporting in an editorial, "How History is Written:"

The American public has had striking illustrations during the past week of he way most histories of the past have been written....

The cables were busy bringing over to the readers of American newspapers vivid and alleged true accounts of the doings of the English, the French, the Belgians, the Germans, the Russians, and the Austro-Hungarians.

To one who did not know how the present day history was being compiled it would undoubtedly seem the French, the English, the Russians and the Belgians were the fairest, bravest, and most generous of people 
while it would appear that the Germans and the Austro-Hungarians were the most vicious and savage of peoples....

One would also believe, if he did not know... that the Germans and Austro-Hungarians were the aggressors in every affair....

But the most intelligent Americans knew that this history is all one-sided written by military censors....

..... It may be claimed that the Germans and Austro-Hungarians would do the same if they had control of the cables to this country.

.... [M]ost of the histories of the past written the same way.... and have caused much of the inherited enmity of today.... 18

Clearly the English-language newspaper agreed with the criticisms raised by the Anzeiger und post.

In supporting the cause of Germany, the local GermanAmericans acted much the same as German-Americans in other cities. Noisy demonstrations had been held in Chicago and Buffalo, for instance. Furthermore, as historian La Vern Rippley has pointed out, the German-American immigrants who arrived after 1871 generally thought well of the Imperial Government. 19 Around the turn of the century, the local German-Americans had followed with interest the course of the Boer War and favored the Boers over the English. At that time, Kaiser Wilhelm II had incensed the English with his remarks. Many, especially the English, believed that Germany supported the Boers. 20 In 1900 in Lawrence, an illustrated lecture favorable to the Boers was held in the German Central Hal1.21 At the same time, Manchester's Germans organized a sympathy committee for the Boers and held meetings at the 
various halls to generate a sympathetic understanding for the Boer cause. 22 The Anzeiger und post wondered why England could violate the rules of the seas, 23 foreshadowing the the issues from 1915 to 1917. From March to December 1900 it reported news summaries on the war under the title "England's predatory war" ("Englands Raubkrieg"). 24 Such actions indicate a willingness to support German causes and what was considered a Germanic minority against the English. Between the Boer War and World War I the German public began to view England as a commercial and military rival. Likewise, a number of German-Americans subscribed to similar views.

With Germany now involved in a war, local Germans could do more than form sympathy groups--they could raise money to assist the victims of the war. Committees soon formed to raise funds for the German branch of the Red cross (commonly called the German Red cross). It was astounding how quickly the benefits, bazaars, and collections began. By september 12 , the Lawrence stadtverband had collected almost $\$ 750$ in relief funds. 25 In Manchester, proceeds from the already planned German Day to be held at the Amoskeag Textile Park and the Harugari-Halle were designated for the widows and relief fund as well as the proposed Manchester Altenheim fund. 26 The Anzeiger und Post printed its first list of contributors to war relief containing 382 names. 27 one week later Manchester contributors were listed with Adolf Wagner leading the collection with $\$ 431.28$ The printing of lists 
now continued in rapid succession. 29 collections for the German Red Cross or widows and orphans occurred in nearly all cities with German populations, and the printing of contributor lists was almost universal.

Specially planned bazaars provided another method of raising funds. St. Louis and cincinnati had elaborate bazaars, as described above. In October 1915, Manchester conducted a "War Relief Bazaar." Held in the Harugari-Halle, it included entertainment by the locally renowned schricker's orchestra and the Mannerchor, and the children of the German School sang Deutschland, Deutschland über Alles. The bazaar raised over thirteen hundred dollars for the relief fund. Among those contributing items for sale was Agent Herman Straw of the Amoskeag, who contributed 150 yards of cloth. 30 Manchester's Germans also decided that proceeds from the planned German Days on September 22-23, 1916 would benefit both the alten Heimat und des Altenheims. Manchester German-Americans had been attempting to establish a "German old peoples home," much like the ones in Lawrence and Roxbury, but never succeeded with this goal. A number of Manchester's Vereine supported the event held in the Turnhalle under the auspices of the stadtverband. The main speaker at the event was pastor Kamm of the German Presbyterian Church, thus, uniting that denomination with the Vereinsdeutschen in fundraising events. An estimated 500 people attended the last evening. 31 In December 1916, the Manchester "German Women's Alliance" organized a bazaar to 
benefit the German Red Cross. The "West Side" correspondent of the Manchester Union reported that over 400 attended the event. 32 In typical fashion the Anzeiger und post reported it as a "huge success."33 It is noteworthy that as late as December 1916 the English-language paper contained reports about the collection efforts of the German-American citizens of Manchester for the German Red Cross.

Early in 1916, the Anzeiger und Post explained the purpose of the German Red cross to its readers. It noted that the Red Cross was a "private organization... founded before the war... for social welfare.... It operated all over Germany... and supported the widows and orphans of those killed in the war."34 These were causes which tugged at the purse strings of local Germans, and which could be considered noble in the eyes of the non-Germans. Thus, in March 1916 a large benefit concert (Grosses Wohltatigkeits Konzert) was held in Lawrence. According to the news report every seat was full and it was "standing room" only, with over 1,300 in attendance. 35 This made it one of the largest German events in some time.

Buoyed by such success, plans were soon made for an even larger event. It would be a fund raising event to coincide with "German Day," but be expanded into "German Week," from August 17 through 20, 1916. Both of the English language papers of Lawrence featured the event, announcing its occurrence ahead of time and reporting on its activities. One described the "beautifully decorated booths and gaily 
dressed men" and described the "auspicious opening."36 The papers prominently featured pictures of the local organizers and the guest speaker, professor Eugen Kuehnemann of the University of Breslau.

Importantly, the event united Kirchendeutschen and the Vereinsdeutschen in a common cause. Over twenty-four different Vereine, both men's and women's sections, were involved including the clubs of the German Methodist, Presbyterian, and Catholic Churches. The main bazaar was held in the hall of the Turners, a group often considered anti-clerical and liberal. For several events the various groups combined, as on Friday at a concert involving the choirs from the three denominations. Sunday morning the German Presbyterian and German Catholic Churches conducted a joint ecumenical "patriotic service." 37

Several other aspects of the event are of interest. The Fest committee produced an elaborate souvenir booklet of thirty six pages. Most of the German and many non-German businesses in the city, and several German and non-German political candidates, including Mayor John Hurley and Alderman James Cadogan, advertised in the book. Additionally, Vereine and German businesses of Manchester combined for one page of ads. Irish business in the city supported the event with advertisements and in other ways. 38 In keeping with the German-American theme of Germania the mother and Columbia the bride, the event featured a "living picture" of Miss Liberty and Miss Germany. Placing a contribution into their drum 
caused one of the costumed women to ring the liberty bel1. 39 Attendance was not reported, but must have been into the thousands. 40

At the same time that they raised funds for Germany, the local Germans actively worked to keep the United States neutral, to end the arms trade, and to counteract pro-British sentiments. They found a willing ally in the local Irish. Association with the Irish was a common occurrence during the European phase of the war, and especially after the "Easter Rebellion" of 1916 in Ireland. The Irish and Germans put aside previous conflicts in their mutual desire to keep the United States out of the War as an ally of England. In other parts of the country prominent Irish politicians were in demand as speakers at German meetings. 41 In Lawrence, the Irish controlled the elected and appointed positions in city government. Therefore, local cooperation between Irish and Germans proved possible.

German-Amexicans in Manchester and Lawrence exercised their rights as citizens in discussing the events of the war. The extent of the actions appear to have been mass meetings and addresses to political representatives on the state and federal level. Believing that American neutrality favored the British, they wanted to sustain the official U.S. position of strict neutrality. They pointed out, for example, that the manufacture and shipment of munitions flowed from America to England. They also pointed out that the English blockade of Germany prevented German dye stuffs 
from reaching the textile mills of their cities. The stadtverband planned most protest activities, although their pro-neutrality stance led them to support and be joined by Irish protest groups.

The scope of this activity may be demonstrated by a mass meeting for neutrality organized by the Lawrence Stadtverband. Organizers included editor Max E. Trumpold and Adolph st. Linger, a designer for the Essex Company, who would soon become a key Liberty Loan collector. American and German flags bedecked the city hall auditorium, site of the March 12, 1915 meeting. Crews from the ships (Cincinnati and Amerika) interned in Boston Harbor provided entertainment. The organizers carefully planned for the meeting to begin with the singing of The star spangled Banner and to end with America. The event followed a regular pattern: German speakers who reinforced the German view, an Anerican who favored the German cause, and an Irish speaker who shought to unite the Germans and Irish in common cause. Fifteen minutes after the doors opened the hall was filled to capacity, and hundreds more wished to enter. An estimated 2,000 persons attended. 42

Those who got in enjoyed an evening of rousing speeches. Unjust attacks on Germany earned condemnation. John Albrecht Walz, Professor of German Literature at Harvard and leader of the staatsverband von Massachusetts, reminded the listeners that all of "Europe is involved, [and] hence the 'mother lands' of all Americans are involved. Then why 
should only Germany be attacked?"43 professor walz told the listeners that this was not only unfair, but that the German cause was as just as that of the other belligerents.

The listeners heard that the British blockade could cost them their jobs, bring the problem close to home. Dr. Edmund von Mach told the audience that England's embargo on chemicals and dyestuffs harmed local manufacturers, since Germany produced "over eighty percent of the world's dyestuffs, while America produced only about ten percent. This was a life or death question for Lawrence." 44 England could harm local manufacturing, but England received much of her war materials from America, some manufactured in New England. In this case the might of England was unjust.

opinions from non-Germans favorable to the German cause reinforced the beliefs of German-Americans. Reverend Levi Powers of Gloucester, Massachusetts announced that "he had no German blood, but he was here to speak for justice."45 He decried the lies being spread about Germany and called Germany one of the world's greatest countries. He said that England was not fighting to protect Belgium but to destroy Germany. German-Americans felt relieved that not all AngloAmericans sided with England.

Reiterations of Irish- and German-American contributions to America swelled the pride of both groups and motivated them to work together. The last speaker Matthew cummings of Neponsett, Massachusetts, past president of the Ancient order of Hibernians, strode to the podium accompanied by strains of 
Deutschland, Deutschland über Alles, and was warmly greeted since "he was known personally" by many of the attendees. 46 He reiterated the loyalty of the participants to America noting that they had "gathered as American citizens who loved their flag and institutions. 47 He reminded the listeners that the American Revolution had been won largely through the efforts of Germans and Irish, especially the German and Irish heroes von steuben and John Barry. 48 The meeting took up Cummings' call for absolute neutrality and enthusiastically passed a resolution to be forwarded to Congress. The resolution called for true neutrality and an end to the export of all war materials. 49

Manchester's German-Americans organized no such mass political meetings. They expressed their displeasure with the munitions trade and their desire for neutrality through their political representatives. State Senator Adolf Wagner introduced a resolution into the New Hampshire Senate calling upon New Hampshire to be neutral and to support the neutrality of the country. Further, it called for the end of the exportation of war materials. In the New Hampshire house, representatives Gustav Wenzel and John Piller were expected to support the resolution, 50 Regardless of the expectations of the Anzeiger und Post, the New Hampshire Senate saw no need for the resolution and defeated it. 51 Meanwhile, submarine attacks drew America closer to war with Germany, an action unthinkable for German-Americans. The responses of President Woodrow Wilson to Germany colored 
the 1916 presidential election and drew the National GermanAmerican Alliance into politics. Many German-American leaders in Manchester and Lawrence went along with the political goals of the Alliance and supported Hughes over Wilson.

Beginning in early 1915, Germany declared an unrestricted submarine warfare zone in retaliation for the British blockade. Neutral America, although exasperated with British actions against its shipping, was shocked by the submarine attacks without warning. 52 The issue was dramatized by the torpedo sinking of the British liner Lusitania on May 7, 1915. The Anzeiger und Post followed submarine warfare and the Lusitania prior to its sinking. In February the paper published the German warning regarding submarine warfare against British supply ships. In its March 6, 1915 issue it printed a picture of the ship under the heading "The 'Lusitania' which seeks protection under the banner of stars," ("Die ILusitania' die unter dem Sternenbanner Schutz suchte"). 53 The sternenbanner in the usage of the Anzeiger und Post normally meant the American flag. As a matter of fact, in early February 1915 the Lusitania had flown the American flag as it neared the Irish coast on its trip from New York. 54 The photo of the liner with tugboats was clearly not taken while it was steaming near Ireland. But a discerning reader knew that the British improperly used the American flag as protection against submarine attack. Immediately after the sinking the paper 
reported that the Lusitania carried munitions and hoped that the incident would not lead to war. It also noted that neutrals, meaning the United States, were not free from guilt. 55 Both the flag incident and the munitions on board were considered to justify German actions. However, as the crises entered the exchange of notes phase, the paper reported it as straight news, with little comment.

Many German-Americans viewed the neutrality of the Wilson Administration as pro-British. President Wilson's handling of the submarine attacks caused him increasingly to lose support of German-Americans. The German-American National Alliance organized attempts to defeat wilson. Under the leadership of its state president, Harvard professor Walz, the staatsverband von Massachusetts, D-A. $\underline{N-B}$. convention met in late october 1915 and began to lay the groundwork to prevent Wilson's re-election. Massachusetts Governor David Walsh and the Republican candidate for Governor, Sammuel McCall attended. Both expressed support for complete neutrality and opposition to Congressional efforts to restrict immigration. German clubs from fortyfour cities attended with 122 delegates, and the Lawrence contingent of 15 was the largest from any one city. 56 over one year prior to the election organized Germandom in Massachusetts was working, under the direction of the GermanAmerican National Alliance, to defeat Wilson.

Tensions between Germany and America heavily influenced the 1916 Presidential election. President wilson campaigned 
on the statement that "he kept us out of war."57 He stirred up an "anti-hyphen" issue by impunging the loyalty of GermanAmericans and Irish-Americans in particular. The previous year wilson stated:

You cannot become thorough Americans if you think of yourselves in groups. America does not consist of groups. A man who thinks of himself as belonging to a particular national group in America has not yet become an American, and the man who goes among you to trade upon your nationality is no 5 yorthy son to live under the stars and stripes....5

The Republican candidate, Charles Evans Hughes, tried to appeal to the so called "hyphen" vote without appearing disloyal, but, "whether he liked it or not, Hughes became the German-American candidate." 59 Furthermore, Germans were often considered to be Republican, but in fact they were not so monolithic. Republican Hughes hoped to win the Irish, normally considered Democratic, who were also offended by the anti-hyphen campaign and the perceived pro-British attitudes of the Wilson administration.

The Republican party dominated both New Hampshire and Massachusetts, but Manchester and Lawrence tended to favor the Democratic Party. Local personalities and local issues often decided elections in the cities. In both Manchester and Lawrence the Germans predominated in certain wards, but they did not dominate the wards politically, as there were often Irish and French-Canadians living on the same streets. Furthermore, in 1915 redistricting in Manchester placed most Germans in Ward 11 but Ward 10 also contained some Germans. Prior to the election, Republican candidates held rallies in 
the German halls on the West side. In the end Germans split their vote a number of ways. In Manchester, Hughes won Ward 10 by 25 votes, but Wilson won Ward 11 by 124 votes. Hughes also won Wards 1 through 4. Wards 1 and 2 contained the more prosperous of Manchester's residents, who tended to vote Republican, and Wards 3 and 4 were mixed but contained numerous Irish. Wilson carried the city by 736 votes, which gave him the margin he needed to win New Hampshire by 51 votes. 60 However, Republican Henry Keys won the Governorship and Republican Cyrus salloway won re-election to congress from the district which included Manchester. In Ward 10, Republican Theodore Graf won the most votes for state representative. Fellow German, and Democrat, Herman Rodelsperger came in fifth. In Ward 11, however, Democrat Andreas Schricker ran a poor fourth behind three Irish candidates. 61 Candidate personalities and local issues, such as 1 iquor licensing, decided the local races. In Lawrence, Hughes won the heavily German precincts 1 and 3 (Ward 1), and he also won non-German precincts 13 and 14 , both mixed but heavily Irish, but lost the city by 1,466 votes. 62 Massachusetts remained solidly Republican. Hughes won the Electoral vote and Republican Samual McCall became Governor, while Republican Senator Henry Cabot Lodge won re-election, and twelve Republicans were returned to Congress. 63

Nevertheless, Irish candidates cultivated the German vote in Lawrence. In April 1916 the Lawrence Turnverein celebrated its fiftieth year with four days of festivities. 
Mayor John Hurly addressed the Turners and their guests. He remarked,

I have been acquainted with the German population ever since I was born. I was born in a German neighborhood and I always had great regard for people of that nationality. Yours is a commendable citizenship for any nationality, and your progress here, in Lawrence, has attracted many good Americans.... Germans of Lawrence control $\$ 12,538,650$ of realty... or one fifth of the total valuation of the city. 64

The mayor acknowledged the support of the Germans in his last election campaign and thanked them.65 Admittedly, April 1916 was not yet the height of anti-German hysteria, but during the fall of 1915 the "anti-hyphen campaign had already developed, and to which Wilson had given the full weight of the Presidency in his State of the Union message of 1915."66 In Lawrence, at least, the elected officials were willing to attend a German event and speak favorably of the GermanAmericans and acknowledge their political support.

Mayor Hurley's acknowledgment of the German-Americans of Lawrence earned him their votes in the 1917 election. Even in December 1917, incumbent mayor Hurley felt confident to advertise in the Anzeiger und Post that the was the "friend of the worker" and the "friend of Germans," (den Freund des Deutschtums). 67 Additionally, the paper carried advertisements from candidates Cadogan, Carr, Kane, Saunders and Finnegan. John Kane, the other candidate for mayor, suffered defeat, and Mayor Hurley ran especially well in the German precincts. 68 
As the slaughter continued in Europe through 1915 and 1916 and as submarine warfare festered, the situation became more difficult for German Americans. While German-Americans protested British actions, the opinions of the American press and public became more unfavorable toward Germany. 69 Moreover, the actions of the German-American National Alliance during the presidential election cast that organization and with it many German-Americans in a bad light. Further, the loyalty of German-Americans had been questioned through the "hyphen" issue raised by the President himself.

As 1917 dawned the United states was in a precarious position, its future actions determined by the European belligerents. It did not take long for a bad situation to get worse, and for the worse situation to become the unimaginable. Thirty-one days into the new year Germany resuined unrestricted warfare on all ships traveling into its war zone. Just sixty-one days later the United States was at war with Germany and Austria-Hungary.

Between the new year and the declaration of War, Germans in Lawrence hoped that the unthinkable would not happen, but perceived the dangers of the war much better than the leaders of the German-American National Alliance. As the new year dawned the Anzeiger und Post asked, "Who are the Traitors? "Why was the loyalty of the German-Americans questioned, when those of English origin through malice and lies were attempting to get the United States to fight with England?"70 
Furthermore, criticisms by "Teddy Roosevelt" about the "professional German-American" were one sided. 71 The GermanAmericans complained about weapons and munitions sales to the English, and asked, "Why can't we do without the 'blood dollars?"172 The paper still hoped for neutrality. It "did not wish the United States to join Germany in the conflict, and naturally do not wish to be an adversary of Germany, but wished to remain actually neutral."73 About a month later the paper informed its readers of the break in diplomatic relations with Germany. It expressed concern about GermanAmericans during the crisis. It was the wish of

everyone, the foreign born and the native Americans, for peace. In the case of war no one should wait for the loyalty of the German-Americans.....German-Americans are here and remain here; the dollars that they earn here in America stay in America. Which is more than can be said about the 'noisy-patriots'.... [Should there be war] it is natural for the German-Americans to fight for [America].... They do have feelings for the mothe $5_{4}$ father, and brothers in the old homeland. 74

The editors then returned to the favorite German-American adage about having made room for the new bride in the place of the mother. While wishing for peace, the tone of the editorial made war a foregone conclusion. It clearly reiterated the loyalty of German-Americans to their adopted country.

Leaders of Deutschtum in Lawrence perceptively sized up the situation regarding the future of relations between Germany and the United States, and what war would mean for German-Americans. As long as the German-American National 
Alliance remained in existence, the stadtverband of Lawrence remained active. In February 1917, the president of the Massachusetts staatsverband, Professor Jchn Walz, addressed the members of the Lawrence local. He spoke of the efforts of the National Alliance to raise money to assist the Central Powers. However, local members addressed a petition to the national president and requested that the National Alliance in the "case of war with Germany must remain loyal to America."75 Furthermore the German-Americans would serve their new homeland with "possessions and blood."76 German citizens of Lawrence implored the German-American National Alliance to "remain at its core a patriotic institution."77 Lawrence's Dr. Karl Eidam declared that the Lawrence Stadtverband should begin to consider supporting the American Red Cross. 78 Men convinced of the values of German culture, also believed strongly in loyalty to America.

As the United States and Germany moved toward war, the Anzeiger und post expressed its feelings in an editorial, "A Mad World:"

....[N]ow in Europe millions of wives, mothers and fathers suffer pain over the deaths of their spouses and sons and are filled with bitter hate against the world and despairing hearts....[S]hall America become involved and help widen the killing? Shall America sacrifice American Iives... [and] send its young men across the ocean to the massache?

surely, it is a mad world. 39

Unfortunately, the answer was yes. Four days later the United States was at war with Germany. In the issue following the declaration of War, the Anzeiger und Post 
printed a report of the events, an editorial from the New York stadtszeitung reminding the readers that the situation was changed and advising them to await the President's next address, and a picture of the American flag and the verses of the "Star Spangled Banner" in German. 80 In essence the news was anti-climatic and offered the good advice to be careful.

The Wilson administration now demanded "one hundred percent Americanism" and the President himself set the tone, warning "woe to any man or group of men that seeks to stand in our way."81 Different opinions about the war were no longer tolerated. The loyalty of certain citizens was questioned. Americans discovered that over four million residents were born in the central powers and feared their reaction to war with the old homeland. 82 Mindless hysteria soon gripped the land: street names changed--in cincinnati Berlin became Woodrow street; "Sauerkraut" became "Liberty cabbage." Such foolishness was replaced by the hounding of citizens and even the lynching, near st. Louis, of partially blind Robert Praeger. 83

With such feelings in the land, the war years proved extremely difficult for the German-language press, which was considered a menace and disloyal. 84 suspecting disloyalty, Congress in October 1917 enacted the first law in American history specifically designed to control the foreign language press. Commonly called the "Espionage Act," it required that exact translations of all items relating to the war had to be 
submitted to the local postmaster. Carl wittke has noted, "obviously, any paper which wanted to stay in business had to support the war and the government's war aims." 85 This requirement, in effect, censored the German-language press. It also proved to be cumbersome, causing delays in reporting war news and adding to the expenses of the local newspaper. To assure that they were considered loyal the papers contributed space for "Liberty Loan campaigns," draft or alien registration instructions, or other war related instructions. The problems caused by the war cut in half the number of German-language newspapers. 86

The Anzeiger und post recognized the dangers the war would bring to peutschtum. Less than three weeks after the declaration, it editorialized about the "War against the German Language." It attacked the views expressed of the New York Sun which had editorialized "when the war comes, the first order of business will be to outlaw any enemy languages in newspapers."87 The Anzeiger und post concluded that German-American citizens had a right to newspapers in their language. The paper also recognized that the war challenged the future of Deutschtum. 88 It hoped for a short war and concluded that the results of the war would propel a number of German speakers to emigrate to the united states. These German-speaking immigrants would give Deutschtum a new life. 89 Even a year later the paper returned to the theme of the future of Deutschtum in America. At this time the German-born and American-born of German ancestry were forced 
to look upon things with "American eyes."90 But it was without question that the Germans who had selected this land were loyal to it, but they could also remain true to "genuine German-ness."91 In this way they could continue Deutschtum as American-German-ness. Here the paper recognized the basic conflict of loyalties and the potential problems it caused for the continuation of German clubs and churches.

The Anzeiger und Post decided to address issues surrounding the German government and German clubs, schools, and churches head on in an editorial, "Das amerikanische Deutschtum." This had to be done since it felt that in some areas of the country, Deutschtum in the United States was being accused as being the same as the German Government. All should know that American Deutschtum had "made its own way, without any help from the other side of the ocean." 92 In fact, the American Vereine had been founded before the present government in Germany (1870):

The Germans in this land have no enthusiasm for the militarism, and the Junker system in Prussia is a thorn in the eye.

German churches and German clubs, which were established in this land, had a spiritual bond with the old fatherland, but no political connection. our language is German, but our convictions are decidedly American. The schools in which we learn German have no connections to Germany. The first German schools were established in this land almost a hundred years before Germany was anything more than a geographical concept.... The German-press in the United states, especially in the last year, has supported the Government and been loyal to the interests of our adopted fatherland. These loyal convictions are found in all German churches and clubs.... It would not be otherwise possible for the Deutschtum of this land... The agitation against the German 
language is irrational and against the truth. 93

Deutschtum in Manchester and Lawrence demonstrated its loyalty. Clubs and churches ordered a "duty flag" and prominently displayed it and the American flag. 94 clubs and churches joined "Liberty Loan" fund raisers, and all choral concerts started with the "star spangled Banner."

Furthermore, in the editorial the Anzeiger und post separated Deutschtum and German culture from the Imperial Government. Germans in other cities failed to make this distinction. In times of war it is not always easy to maintain such distinctions, but the American government and the local English language press also made it. 95

The daily papers of Manchester and Lawrence reflected a certain measure of the tolerance of the community toward the local German-Americans. The papers recognized the loyalty of the German-Americans and sympathized with their predicament. They also reported on their activities in support of the war, and they continued to report on German-American events.

At that time Lawrence had two daily newspapers. The Evening Tribune, published by the Hildrath and Rogers Company, favored the Democratic Party. It is at this paper that young Max Trumpold, now the editor of the Anzeiger und Post, worked shortly after immigrating. Even though Democratic, it did not take up the anti-hyphen issue and favorably reported on the local Germans. The Lawrence Telegram, published by Kimball G. Colby, favored the Republicans, and remained skeptical and critical of a number 
of the policies of the administration and favored Hughes over wilson in the election.

In Manchester, Frank Knox and John A. Muehling, both ardent Republicans, co-owned both dailies, The Union and the Leader. John Muehling, the son of a German emigrant, had published a German-language daily and operated a printing shop in Michigan. In 1912 he moved to Manchester with Frank Knox to establish The Leader in order support Teddy Roosevelt's Bull Moose party. In 1913 they purchased the rival paper, The Union. During World War I, Frank Knox served in France leaving Muehling in charge of the paper as publisher and editor. Although a second generation GermanAmerican, Muehling apparently belonged to none of the German clubs of the city, but rather to the American clubs. one biographical report lists him as a member of the Lutheran Church, but he was buried by the congregational church. Muehling actively supported the American cause in the war, but the editorial policies of the paper were careful to separate the Kaiser from the German-people, and the paper was balanced toward Manchester's German-Americans. This is possibly the result of his German heritage. 96

At the start of the War, the Manchester Union and the Lawrence Telegram and Evening Tribune immediately recognized the loyalty of German-Americans. 97 The Evening Tribune recognized that German-Americans would naturally be interested in Germany: it pointed out that the "great majority are American citizens," and "they.... would be found 
fighting side by side with native Americans."98 It further cautioned "let the proper authorities investigate the suspicions, while we as citizens live in harmony and friendship with those whose acquaintance we have had for years."99 In Manchester, matters intensified when a German Pastor gave a passionate address to the Manchester Minister's Association. Reverend Joseph Hollrigl, German-born but also an American citizen, spoke about the conflicts between his love for the land of birth and love for America. He concluded that German-Americans would be firmly and unswervingly for America. The meeting was moved to a vote of "sympathy for the clergyman and the great body of Germans which he is believed to represent. "100

A short time later the Manchester Union editorialized against the miscalculation of the German government and press. According to the editorial the German government expected German-Americans to rally to the Kaiser's standard, and that they did not do so, displeased the German press. It cited the Kreuz zeitung which accused German-Americans and their associations of "cowardly zeal with which... [they] disown their own race."101 The union concluded: "here is their home, their vital interests, their hopes and their loyalty. And they are coming up handsomely to the call of our nation."102

This relative tolerance continued throughout the war. The papers made the distinction between the German people and the German government. The tolerance is demonstrated by the 
Union Leader, which only four days after the Armistice favored aid for Germany! It stated, "The simple fact is that we have got to rescue Germany to effect a speedy and sound peace."103 Throughout the war, the papers reported on the activities of the churches and clubs, especially on the West Side of Manchester. The daily papers also featured GermanAmerican contributions to war efforts.

German-American contributions to the war earned the support of the daily papers and of their fellow citizens. They served their new homeland with "possessions and blood," in the words of the speaker at the February 1917 meeting. Both as a means of raising funds and generating patriotic fervor, the government embarked on Liberty Bond or Liberty Loan campaigns. Individual and organizational purchases of bonds soon became a popular test of patriotism. Bond campaigns generally took on offensive "Halt the Hun" characteristics. Superpatriots used them to intimidate German-Americans and other groups who appeared slow in buying bonds. German-Americans and German clubs quickly joined the bond bandwagon. 104

German-Americans in Manchester and Lawrence joined the bond campaigns. Lawrence's massive Liberty Loan Drive in April 1918 included a large and enthusiastic parade. The Turnverein massed 200 hundred marchers but was outclassed by the Harmonie Lodge, of the Sons of Hermann, which had 300 . The German and Polish units were commanded by Ernest o. Dick, son of the prominent builder and nephew of the editor of the 
Anzeiger und Post. Both daily newspapers reported favorably and in detail on the German marchers. 105 The Anzeiger und Post printed an exhortation from the New England Liberty Loan Committee. The paper stressed that the minimum quota of the German-Americans was in the patriotic spirit of the city and would preserve American freedom. German-Americans would sell bonds through patriotic meetings in their halls and through door to door campaigns. 106

Ominously, a week later Lawrence had noc reached its quota. German-Americans assembled in the Turnhalle to support the Loan Campaign enthusiastically, in the words of the Evening Tribune. 107 A campaign speech was given by a Professor Vogel, of the Liberty Loan Committee of Massachusetts. The organizers of the event exhorted the various Vereine to subscribe to the loan. Those in attendance elected a committee to continue the efforts to sell Liberty Bonds to German-Americans. In a graphic case of continuity, the elected chairperson of the Liberty Loan committee was Adolf st. Iinger, the former head of the Lawrence stadtverband of the German-American National Alliance. In the minds of the attendees his former position did not disqualify him from liberty Bond fund raising, and he must have been able to get along with the non-German organizers of the bond drive. Coincidentally, the day the German-Americans held their meeting Lawrence's Liberty Loan campaign went over its quota. 108

Periodically, the Anzeiger und post devoted space to 
sell Liberty Bonds. In addition to advertisements, it included articles obviously prepared by the government for the German-Americans. In one issue, four such articles appeared. One asked "What is Patriotism?" and concluded that purchasing "Liberty-Bonds" was a good part of patriotism. Another asked "What would Carl Schurz Do?" Regardless of what else he might do, he would buy Liberty Bords. GermanAmericans like all Americans wanted the war to end, and an article "How Much Longer?" appealed to this sentiment; it suggested that buying "Liberty Bonds would bring peace closer."109 Earlier in the war the Manchester Union, surprisingly, had complained about giving the government so much "free space for its Liberty Loan propaganda," in effect, "giving free advertising space" while the "postage charge for papers is too high."110

In April 1918, Manchester also conducted a Liberty Loan Campaign, and here too there was a parade to generate enthusiasm. The Manchester Union billed it as the biggest demonstration up to that time in Manchester. Secretary of the Navy Josephus Daniels and Governor Henry Keays officiated. Prominent among the estimated 10,000 marchers were employees of the Amoskeag and other Manchester companies and members of fraternal and ethnic organizations. The Turner Gymnasium classes marched under the leadership of instructor Max Hoffman and president Gus Wenzel. The Manchester Union reported that the "leader of the unit declared to the public, 'that we are of German descent but 
Americans, first, last, and always, 100 percent.' As further proof three service flags of 17,19 , and 10 stars respectively were presented."111 Each star represented a member in military service. That the leader felt compelled to make such a statement illustrates the group's need to affirm its patriotism to the larger community.112 Additional German-American organizations, each carrying their service flags, also marched. 113

Indeed, the numbers on the service flags indicate that many German-Americans served in the armed forces of the United States during the war. One list for Manchester contained 84 names. Fifty-three members of the Manchester Turn Verein served. The German-Americans of Lawrence, likewise, proved their patriotism by serving in the armed forces. For example, the service flags of the Harmony Lodge and the German Presbyterian Church contained 36 and 31 stars respectively, and the Turnverein had at least 39 returning soldiers in 1919. Some gave their lives in the service their country. 124

Despite the military service of German-Americans and despite their favorable treatment in the daily press, Manchester was not without anti-German incidents. The Liberty Bond campaign and parade triggered one incident. One German born resident, August Kaps, decided neither to march nor to buy Liberty Bonds or Liberty stamps. His actions led to his dismissal from the stark Mills, when his fellow workers decided that they would not work in the same room 
with him and charged him with being pro-German. A delegation of the German clubs on the West side organized and attempted to meet with his bosses to resolve the issue. ${ }^{115}$ The FrancoAmerican newspaper I'Avenier Nationale wrote that the incident proved that "Germans remained German whatever their adopted land and whatever the favors extended to them."116 Franco-Americans, many of whom were non-citizens, were accused of avoiding military service first in canada, which as an English dominion had been at war for several years, and in the United States, where as non-citizens they were not subject to the draft. Therefore, they may have used the parade and the incident to affirm their loyalty to the United States. 117 In fact Kaps was a sad case, hardly a threat to anyone. His wife had been in the New Hampshire hospital for the insane for three years, and he had four young sons he was attempting to support. Apparently he received assistance from the German societies and from a friend who also took care of the children. Kaps had been arrested once and was held pending an examination as to his sanity. The Manchester Union reported sympathetically on the actions of the German clubs on Kaps' behalf. 118 The resolution of the issue remains unknown, for there was no further reporting on it, nor has any other information been uncovered. As an antiGerman action, although unfortunate for kaps, it was a rather minor affair.

A more chilling incident occurred when the Espionage Act silenced one local German's free speech. A Federal case was 
made out of remarks made in a drug store by Gustave Taubert, an illustrator for the Manchester Union. 119 A Mrs. Cora Morin reported him to the local authorities for saying that the flag was mortgaged to J.P. Morgan. Others testified that he spoke against Liberty Bonds and said that America should not have gone to war. Moreover he was accused of saying that it was unfair for the Irish and French to be in the trenches for England. Taubert denied the charges and indicated that the incident stemmed from disputes with the parties involved. He testified that he was born in Alsace and arrived in the United states in 1873 when he was less than a month old. Edgar Lealie, a photographer, Officer John O'Dowd of the Manchester Police Department, and Herman Rodelsperger of Manchester testified to his character. 120 Nevertheless, Taubert was found guilty $y^{121}$ and sentenced to three years in prison for his statements. 122 Later, otto Englehardt, of Goffstown, received a one year sentence for saying that the Taubert case was unfair. 123 As with many such incidents, World War I became a cover for personal vendettas. However, the Taubert case undoubtedly forced many local Germans to be more circumspect in their speech. It was a black mark on an otherwise fine record of fair treatment of German-Americans in Manchester and Lawrence. 124

An infamous incident occurred in Boston, the beacon of freedom to Karl Heinzen, that showed the type of mindless hysteria possible and the alternate reaction of the local Germans. It will be recalled that Germans had established 
music in Boston. Dr. Karl Muck, German born but a Swiss citizen, was then the conductor of the Boston symphony orchestra. He refused to play the "star spangled Banner" at a performance in Providence since he felt it was out of place in a symphonic program. He subsequently played it, but he was hounded by citizens and officials in Boston until he was removed from his post, interred at a military camp in Georgia, and deported after the war. 125

Manchester's tolerance for German music was apparently greater than Boston's. In June 1917 the Turner Brass Band held a concert in Hollis, New Hampshire. In September, 1918 , the same band performed at the Amoskeag as part of the "municipal band series."126 In Lawrence in october 1917 the noted Austrian violinist Fritz Kreisler performed to an overcrowded Lawrence Opera House. 127 Less than two weeks later in Pittsburgh, Pennsylvania the director of public safety cancelled a scheduled kreisler concert. ${ }^{128}$ In 1919 , in Manchester Kreisler performed to a full house and an appreciative audience, even though his performances were canceled due to protests in other cities. 129

Despite the earlier incidents in Manchester and the Muck affair in Boston, German-Americans in Manchester and Lawrence felt comfortable enough to continue their Vereinsleben, including even a number of New England wide meetings during the war. The English-language dailies carried news about German-American local and regional events through the middle of 1918. During the war, the Vereine of both Manchester and 
Lawrence kept up a relatively normal routine. Weekly dances, concerts, and festivals continued. In 1917, the twenty-fifth anniversaries of the Lawrence Free Bed committee and the Manchester Bavarian Club provided occasions for celebration. According to the Manchester Union, over 600 attended the Schlachtfest held in November, 1917 at the A.K.U.V hall. 130 In April, 1918 between 400 and 500 people attended the Fruhlingsfest in the Lawrence Turnhalle. Also in Lawrence, the Harugari club held a schlachtfest on November 2 and 3 , 1918. Clearly, Deutschtum was alive in Lawrence even late in the war. 131 In Manchester festivals became more difficult, because New Hampshire passed a prohibition law prior to the Eighteenth Amendment, and Manchester was hard hit by an influenza epidemic so severe that schools and theaters closed. According to the West Manchester reporter, "the presence of the prohibition law was impressively brought to the West side saturday night. The club rooms were empty. The club members do not find the same attractions." 132

In addition to the local events, the New England-wide club meetings and events continued throughout 1917 and 1918. officers of the Turnverein of the various cities held planning meetings in the various cities. In April 1917, such a meeting was held at the Lawrence Turnhalle, and Mayor Hurley welcomed the delegates from around New England and presented them with the keys of the city. ${ }^{133}$ In May the New England sangerbund held a meeting in Lawrence. The attendance of the Manchester Mannerchor at the meeting was 
reported in the home city paper. 134 During the summer of 1917 the annual Turner gymnastics competition was held in Holyoke, and participants from Manchester and Lawrence attended. 138 These events continued in 1918. In March, the Manchester Turn Verein hosted the delegates meeting. 136 Lawrence hosted the New England sangerbund in May and the Turner gymnastics competition in June. 137 Manchester Turners joined 122 other young men and women from several New England cities in the competition. 138 and in August, the annual meeting of the Harugari association was held in Fitchburg. 139 At these events over twenty clubs from different cities could be represented including Adams, Holyoke, Springfield, Fitchburg, Clinton, Boston, Cambridge and Roxbury. Clearly, the Germans of Manchester and Lawrence, as well as the othe: industrial cities of New England felt confident enough to hold these festivals which, because of the out of town visitors, attracted attention. The English-language daily newspapers were not roluctant to report on them. Given the reported anti-German hysteria in other cities this was a remarkable display of confidence by the German-Americans and tolerance by the local population. However, it would appear that the Germans of the two textile cities were respected by the civic leaders and majority of citizens and were probably perceived as a small, respectable, hard working community which did not challenge the established political structure. In a sense the smallness of both the German-American populations and the cities themselves probably led to closer 
and more positive contacts than in the large metropolitan centers.

If the Vereinsleben hardly slowed down during the war, it resumed in full force after it ended, though new problems began to appear. Fund-raising activities turned from "Liberty Loans" to relief efforts for Germany and Austria. Disillusionment over the war and the peace treaty and especially its treatment of Germany soon set in. The Anzeiger und Post returned to earlier themes about German language and customs. Almost every week the paper attacked Prohibition and campaigned for its repeal. The paper was also concerned about the the meaning of imnigration restriction laws.

Social activities of the German clubs continued in full swing with the new year. In January, the Manchester Harugari Association held a stiftungsfest and the Lawrence counterpart held a costume ball. Some events were quite popular. It was reported that 600 attended the rag ball in the Turnhalle in late March. 140 The anniversary of the founding a club was always an occasion for a festival, and during 1919 the Lawrence Liederkranz, the Manchester Beethoven Munnerchor, Schulverein, and Schiller lodges celebrated ${ }^{141}$ At the same time the clubs held their New England wide executive meetings and festivals. The Turners held their meeting in Holyoke and in June their gymnastics competition in Webster. The 1919 Harugari convention selected Lawrence to host the one the following year. 142 
If things appeared to be normal in the Vereinsleben, signs of difficulties were evident. Prohibition made it more difficult to raise operating funds. In 1919 the Gesangsvereins Lyra sold its hall to the Lithuanian Citizens' Club. 143 The foundations of the Lyra went back to 1871 , and in 1888 it built its large and beautiful hall on Park st. The Lyra continued to sing until the 1930s, but it now met at and held its concerts at other German halls. Dwindling revenues from dues, attendance at concerts, and lack of beer sales most likely forced the club to sell. The Lithuanians represented a newer immigrant group acquiring available club space.

Raising funds for a worthy cause provided clubs with occasions for holding various events such as bazaars, dances, or concerts. The causes still included the Altenheim, the Freibett, and the German School, but now included help for Germany. The paper began printing reports of the difficult times in Germany. In the late summer of 1919, an aid fund was established in Philadelphia, to direct funds to Germany. Additionally, the emigrants from Glauchau, Saxony living in Lawrence and Fitchburg started a fund to raise money for the children of Glauchau. These relief efforts would continue to unite the Kirchendeutschen and the Vereinsdeutschen In December, various Vereine and the German Presbyterian Church and Mariahimmelfahrt sponsored a benefit concert and ball held at the Turnhalle. ${ }^{144}$ Manchester was also active in charity work, collecting funds and holding a bazaar and 
dinner, which raised over $\$ 740$ for the aid fund. 145

The Anzeiger und post soon recognized the post war mood of the German-American community. It took up four main themes after the war. First, it returned to its emphasis on learning German and preserving German culture. Recognizing a trend, it challenged German-Americans to make Vereinsleben more than a weekly dance. Secondly, it saw Prohibition as not only an attack on personal liberty but also an attack on the lifestyle of immigrants in general and Germans in particular. It recognized that Prohibition created economic hardships for the clubs. From now until 1933, it attacked it relentlessly. Thirdly, the paper opposed immigration restrictions. It noted that immigrants had served in the armed forces and that about seventy to eighty percent of the workers in the munitions and shipbuilding industries had been born in Europe. The paper did not consider that there was an immigration problem. Finally, conditions in Germany merited concern, and the protracted peace negotiations earned criticism. This indicates a turning from unquestioning and prudent patriotism to an attitude of questioning the actions of government. 146

\section{Conclusions}

In Manchester and Lawrence Deutschtum not only continued through the war, but survived and revived after the war. There are several probable reasons for this. Although some Germans entered politics, they never challenged the political control of the Irish in Lawrence nor the Anglo-Irish in 
Manchester. The German votes did not constitute a block large enough to control the outcome of an election. Neither was their vote ignored. Germans often held one or two positions in city government in most years. Also, prior to America's entry into the war, German- and Irish-Americans had similar goals. Additionally, German-American business leaders were well regarded by their counterparts. German workers had higher level and important positions in the mills and were respected by their employers. Generally, the English-language newspapers were sympathetic to the GermanAmericans, and not prone to hysteria. Since the states were Republican and the anti-hyphen issue was a Democratic one, the papers and political leadership avoided offending GermanAmericans. The Anzeiger und post probably helped its readers through the rough times, and it actively pushed for the revival of Deutschtum after the war. The Anzeiger und Post perceptively distanced Deutschtum from the government of Imperial Germany.

Most importantly, unlike Germans in Cincinnati, Chicago, and St. Louis who were unable to unite, Germans in Manchester and Lawrence overcame the divisions of the old country. Vereinsdeutschen and Kirchendeutschen cooperated in common cause. There are several probable explanations. One is that the community was so small that it leaders and members got to know and respect each other. Secondly because the community was so small the need to unite for a common cause and against a common threat was much greater than religious or political 
enmities carried over from the old country. Thirdly the German Presbyterian denominations, with many of the community leaders as members, seemed to be flexible. Likewise, members of Mariahimmelfahrt siowed a willingness to join with other Germans, which did not typify German Catholics in other cities. The ability to overcome old world animosities to unite for a common German-American cause indicates a large measure of assimilation.

Deutschtum in Manchester and Lawrence remained alive and active through the 1920 s and 1930s. It was not private. In Manchester and Lawrence the Vereine held public events, and the clubs hosted New-England-wide festivals. The local English-language dailes reported on these events. Local and state politicans attended to garner votes. However, at the same time Deutschtum revived and flourished, it was slowly being eroded by the forces of assimilation. This revival and erosion are the subjects for the next chapter. 
CHAPTER NOTES

\section{CHAPTER VII}

${ }^{1}$ Erick Kirschbaum, The Eradication of German culture in the United States, 1917-1918, (Stuttgart, Akademischer Verlag stuttgart, 1986), p. 32 .

İbid., pp. 13, 14.

${ }^{3}$ Clifford Scott, "Assimilation in A German-American Community: The impact of World War $I$, " Northwest Ohio Quarterly, 52 (1980): 153 .

${ }^{4}$ Ibid., 153-165.

${ }^{5}$ Hawgood, Tragedy of German-America, p. 298. See also Frederick Luebke, Bonds of Loyalty, pp. 310-315. Glazer and Moynihan, Beyond the Melting Pot, p. 311. Richard o'Connor, German Americans, pp. 453-457.

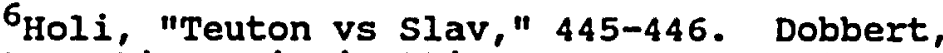
Disintegration: Cincinatti, pp. 404-430. Olson, "St Louis Germans, pp. 204-255. Detjen, Prohibition in Missouri, p. 186. Yox, Decline in Buffalo, pp. 320-324, Gerd Korman, View form Milwaukee, pp. 167-175.

${ }^{7}$ Lyle Dorset, "The Ordeal of Colorado's Germans during World War I." Colorodo Magazine, 4(1974): 277-293.

${ }^{8}$ Dieter Cunz, The Maryland Germans: A History, (Princeton, NJ, Princeton University Press, 1948), pp. 402416.

${ }^{9}$ Tischauser, Burden of Ethnicity, p. 59.

10Ibid., p. 64 .

11 Ibid., p. 119 .

12 Tolzuann, Cincinnati Germans, pp. 19-20, 23-34, 34-39, 195-197.

${ }^{13}$ Anzeiger und Post, August $8,1914$.

14 Anzeiger und post, August $15,1914$. 
${ }^{15}$ The New York Times. August $2,3,4,5$. The English language papers of Manchester and Lawrence were balanced in their coverage at this time and for most of the war. More details will follow below. During the first two weeks of the war The New York Times was definitely against Germany.

${ }^{16}$ Anzeiger und post. August $22,1914$.

17 Anzeiger und Post, August 29, 1914, September 5, 1914. Lawrence Telegram, september 3, 1914. Phyllis Keller, states of Belonging: German-American Intellectuals and the First World War, (Cambridge, Harvard University Press, 1979). See pp. 7-120 for Munsterberg's career and war activities.

${ }^{18}$ Lawrence Telegram, August 10, 1914. A discussion of the English-language papers of Lawrence and Manchester will follow below.

${ }^{19}$ LaVerne Rippley, "Effect of the 1871 Victory on Americana-Germanica," in Germany and America, 122-136.

${ }^{20}$ See Lamar Cecil Wihlelm II, Prince and Emperor, $1895-$ 1900, (Chapel Hill, University of North Carolina Press, 1989), pp. 326-330; and Imanuel Gej.ss, German Foreign Policy 1890-1914, (London and Boston, Routledge \& Kegan Paul, 1976), pp. 70-71, 88-93 for a discussion of the actions of the Kaiser and its effect on the British. The Germans controlled the nearby colony of German West Africa and had business interests in the Transvaal. The Boers descendants of original Dutch settlers were considered Germanic by Germans and many German-Americans.

${ }^{21}$ Anzeiger und Post, March 3, 24, 1900.

22 Anzeiger und Post, March 24, 31, May 26, 1900.

${ }^{23}$ Anzeiger und post, January 6, 1900.

${ }^{24}$ Anzeiger und Post, between March 24 and December 15, 1900. It was a column with paragraph Iong dispatches about the war.

25 Anzeiger und Post, September 12, 1914.

26 Anzeiger und post, September 12, 1914.

27 Anzeiger und post, september 12, 1914. The contributions were mostly small and totalled $\$ 749$.

28 Anzeiger und Post, September 19, 1941. Wagners list $\$ 431$ and the MHnnerchor collected $\$ 19.00$. 
${ }^{29}$ Anzeiger und Post, Spetember 19,1914 contains a Lawrence list of over 200 names. September 26, 1914 has a Manchester list of about 50 names and on October 10 the Manchester list contains about 60 names, there are 1 ists for Manchester on October 17 and 24.

${ }^{30}$ Anzeiger und post, october 23 , and 30,1915 . In typical German fashion a complete income and expense report was given but the attendance was not given. The fair raised $\$ 1,365.21$.

${ }^{31}$ Anzeiger und Post, september 9, 23, and 30, 1916. Manchester Union, August 28, September 22, September 25, 1916. In addition to the stadtverband the Turnvereein, Manchester Mannerchor, Beethoven MAnnerchor, and the Arbeiter Krankenünterstutzungs Verein, were involved.

32 Manchester Union, December 5, 1916.

${ }^{33}$ Anzeiger und Post, December 9, 1916, reported a net of $\$ 600$.

${ }^{34}$ Anzeiger und post, January $22,1916$.

35 Anzeiger und Post, March 25, 1916. It was that the fund earned $\$ 600$. The entrance fee was 25 cents. Subtracting expenses the attendance must have been quite large.

${ }^{36}$ Anzeiger und Post, the first announcement was made on April 15, 1916. Advertisement on August, 12, 1916 and report on August 26, 1916 Lawrence Telegram, August 14, 18, 19. Lawrence Tribune August 14, 18, 19. Among the local organizers were Adolph St. Linger, Carl Herzog, Max E. Trumpold, and state Rep. Frederick W. Schlapp.

${ }^{37}$ Deutsche Woche Fest Buch (ICA 83.69.1), Anzeiger und post, August 12, 1916. Lawrence Telegram August 14, 1916 . Among the Societies participating were the Bayersche Lese-und Fortschritsverein, Deutscher Roter Kreuz-Verein, Dewey Street Citizens Club, East Methuen German Hose Co, Gesangvereine Liederkranz and Lyra, lodges of the Sons of Hermann, lodges of the Harugari, Turnverein, Deutsche Katolische Kirche Frauenverein, St. Aloyisus Verein, Deutsche Methodisten iirche, Deutsche presbyterianer Kirche, and Verin Wahrheitsucher.

${ }^{38}$ Deutsche Woche Fest Buch, Anzeiger und Post, August 26. 1916. Lawrence Telegram, August 14, 1916.

${ }^{39}$ Anzeiger und post, August 26, 1916. Lawrence Telegram, August 14,1916 . Miss Liberty was represented by Miss Cora Trumpold and Miss Germany by Miss Gretchen Beilig. 
40 Anzeiger und Post of September 9, estimated attendance of 5,000. Over $\$ 3,200$ was raised in total. Irish businesses were not reluctant to take out ads in the Eestbuch. The sullivan dealership exhibited the prize car in the window, "at no cost."

${ }^{41}$ Carl wittke, German-Americans and the World war, (Columbus, The Ohio State Historical Society, 1936), p. 25. Carl Wittke, The Irish in America, (Baton Rouge, Louisiana State University Press, 1956), see pp. 181-188 for conflicts and pp. 273-234 for similar views of Germans and Irish. Wittke also states that German and Austrian fund raising bazaars usually had an "Irish night." See also: Edward Cuddy, "Pro-Germanism and American Catholicism, 1914-1917," The Catholic Historical Review, 54 (October, 1968): 427-454; and Dean R. Esslinger, "American German and Irish Attitudes Toward Neutrality, 1914-1917: A Study of Catholic Minorities," The Catholic Historical Review, 53 (July, 1967): 194-233. Also Child, German-Americans in Politics, pp. 52,75 .

42 Anzeiger und Post, March 20, 1915, its estimate was almost 2,000. Lawrence Teleqram, March 13, 1915, its estimate was 1,500. Lawrence Evening Tribune, March 13, 1915, gave a lenghty account of the meeting, and is almost identical to that of the Anzeiger und Post. The Evening Tribune, referred to both ships as "liners." The Anzeiger und Post referred to them as Dampfer, which often means passenger ships. The Lawrence Telegram called it a "monster meeting."

43 Anzeiger und Post, March 20, 1915.

${ }^{44}$ Anzeiger und Post, March 20, 1915.

45 Anzeiger und Post, March 20, 1915.

46 Anzeiger und Post, March 20, 1915.

${ }^{47}$ Anzeiger und Post, March 20, 1915.

${ }^{48}$ Anzeiger und Post, March 20, 1915.

${ }^{49}$ Anzeiger und Post, Marcil 20, 1915.

50 Anzeiger und Post, January 30, 1915. Adolph Wagner was born in Manchester and had a career as a lawyer and politician in Manchester serving as an alderman, representative, and state senator. He ran unsuccessfuly for mayor. Obituary, Anziger und Post, June 29, 1930.

${ }^{51}$ Journal of the Honorable Senate, January $21,1915 \mathrm{p}$. 72 , and January 27,1915 p. 82. The resolution was defeated 
$20-1$

52 Arthur s. Link, Woodrow Wilson and the progressive Era, 1910-1917, (New York, Harper Torchbooks, 1963), pp. 156163.

53 Anzeiger und Post, March 6, 1915.

54 Thomas A. Bailey and Paul B. Ryan, The Iusitania Disaster: An Episode in Modern Warfare and Diplomacy, (New York, The Free Press of Macmillan, 1975), pp. 47-51. The authors contend that the ruse could not have fooled any submarine captain, since the U.S. had no similar ships. The U.S. protested the action to Britain.

55 Anzeiger und Post, May 15, 1916.

56 Anzeiger und Post, October 30, 1915.

57 Link, Woodrow Wilson, p. 242

${ }^{58}$ Quoted in Luebke, Bonds of Loyalty, p. 142 from Wilson, Public Papers, 3:379.

${ }^{59}$ Link, Woodrow Wilson, p. 142.

${ }^{60}$ state of New Hampshire, Manual for the General Court, 1917, Number 15. pp. 354, 373. Manchester Union, November 8 , $9,10,11,12,1916$. The Democratic candidate for Governor, John Hutichinson lost the city to Republican Henry Keys, who won the governorship, by 124 votes.

${ }^{61}$ Manual for the General court, p. 409.

62 Records of Elections, city of Lawrence, Vol. 2, "Presidential Election, November 7, 1916, p. 416-417.

${ }^{63}$ Lawrence Tribune and Telegram November $8,9,10,11$, 12 , 1916. Four Democrats were elected to Congress.

64 Lawrence Evening Tribune, April 14, 1916. Lawrence Telegram, April 15, 1916. Anzeiger und Post, April 8, 15, 22, 1916 The mayor took his figures from the assessors list and figured that the actual value was $16,000,000$ and with 16,000 Germans in Lawrence each owned $\$ 1,000,000$ in property. The Fest Buch had advertisements from John Flanagan Director the Property Department, Robert Maloney Director of the Health Department, Maurice McKenna, Chief of Police, Louis Cox District Attorney, and James Cadogan Director of the Safety Department.

${ }^{65}$ Ibid. 
${ }^{66}$ Luebke, Bonds of Loyalty, pp. 140-43, 145-46. Link, Woodrow wilson, pp. 223-251.

${ }^{67}$ Anzeiger und Post, December 1, 8, 15, 1917.

${ }^{68}$ Records of Elections, city of Lawrence, Vol 2, "Municipal Election December 11, 1917, p. 454.

${ }^{69}$ Link, Woodrow Wilson, 223-251. Child, German-American in Politics, 85-153. Hawgood, Tragedy of German America, 267-310. Baily and Ryan, Lusitania Disaster, pp. 234-236. For a discussion of the change in attitudes toward Germany in general see: Clara Eve Schieber, The Transformation of American Sentiment Toward Germany, 1870-1914, (Boston, Cornhill Publishing Co., 1923.)

70 Anzeiger und Post, January 6, 1917. This was a front page editorial.

${ }^{71}$ Anzeiger und post, January 6, 1917.

72 Anzeiger und post, January 6, 1917.

${ }^{73}$ Anzeiger und Post, January 6, 1917.

${ }^{74}$ Anzeiger und Post, February 10, 1917.

75 Anzeiger und post, February 17, 1917.

76 Anzeiger und Post, February 17, 1917.

77 Anzeiger und Post, February 17, 1917.

78 Anzeiger und post, February 17, 1917.

${ }^{79}$ Anzeiger und Post, March 31, 1917. Wilson delivered his war message to Congress on April 2, which passed it on April 4, 1917.

${ }^{80}$ Anzeiger und Post, April 17, 1917. Anzeiger und Post was less vituperative and sarcastic than New Haven Anzeiger. see H. Wentworth Elderedge, "Enemy Aliens: New Haven Germans During the World War." in studies in The Science of Society, ed by George P. Murdock, (Freeport, NY, Books for Libraries Press, 1937), 218.

${ }^{81}$ David $M$. Kennedy Over Here: The First World War and American Society, (Oxford, Oxford University Press, 1980), p. 46. See Chapter II, "War for the American Mind," pp. 45-92, also his Chapter VIII, "Superpatriotism in Action: 1917," pp. 225-266, and Chapter IX, "Ethnic Reaction: 1918," pp. 267308 . 
${ }^{82} \mathrm{John}$ Higham, strangers in the Land: Patterns of American Nativism. 1860-1825, (New Brunswick, Rutgars Univestity Press, 2nd ed, 1988), pp. 204-213. Higham reports that in $19174,662,000$ persons in the United states were born in the Central Powers, about one half German and the other half from Austria-Hungary, Turkey and Bulgaria. Further, the Slavic and Magyar nationalities dominated the eastern coal fields and perhaps two-thirds of the iron and steel industry. This worried many officials, but the nativists were so out of touch with the immigrants that they did not understand their loyalities. Higham also sees the war as an excuse for Americanization and elimination of foreign influences in American life, see pp. 248-50.

${ }^{83}$ Kennedy, Over Here, see p. 68 for the lynching of Robert Praeger, 68. See Frederick Luebke, Bonds of Loyalty for more details about the Robert Praeger lynching, pp. 3-4, $5-10,15-21,21-23,247,-249$, See

84 "A Growing Demand for the Suppression of the GermanAmerican Press," Current opinion, 63 (September 1917), 151152. Hermann Hagedorn, "The Menace of the German-Language Press," The outlook, 116 (August 15, 1917), 579-581. "Hot-Shot From a German-Born American," Literary Digest, 58 (August 24, 1918) 23. Frank Perry Olds, "Disloyalty of the GermanAmerican Press," The Atlantic Monthly, 122 (July, 1917), 136140. Robert E Park, The Immigrant Press and Its Control, (New York, Harper and Brothers, 1922). Clyde William Park, "The Strategic Retreat of the German-Language Press," North American Review, 207 (May 1918), 706-719.

${ }^{85}$ wittke, The German Lanquage Press, p. 264.

${ }^{86}$ Ibid. Wittke gives the number of German-language newspapers as 537 in 1914 and 278 in 1920, pp. 243, 273.

87 Anzeiger und Post, April 21, 1917.

${ }^{88}$ Anzeiger und post, september 15, 1917.

${ }^{89}$ Anzeiger und Post, september 15, 1917.

90 Anzeiger und Post, April 20, 1918.

91 Anzeiger und Post, April 20, 1918.

92 Anzeiger und post, June 15, 1918.

93 Anzeiger und Post, June 15, 1918.

94 Anzeiger und Post, April 20, 1918, Lawrence Munnerchor concert opened with the "star Spangled Banner". Manchester Union, June 2, 1919, over 60 members of the Manchester Turn 
Verein were in the service.

95 Anzeiger und Post, April 20, 1918. See, Manchester Union, April 5, 1917, To the German People," criticized the autocratic German regime but held out spirit of friendship for the German people. May 28, 1917 "Against Kaiserism," July 6, 1917 "Wanted A German Republic."

96 Hobart Phillsbury, New Hampshire: History, (New York, The Lewis Historical Publishing Co, 1927-28) V 166-168, 38-39 biographies of Muehling and Knox, Manchester Leader, February 22, 1942: Manchester Union April 20, 1944 and April 24, 1944, death and funeral of Muehling: Manchester Union Leader Centennial Edition, March 22, 1963.

There is a set of coincidences regarding Teddy Roosevelt and Germans in the Union Leader. During the Spanish-American War by some fluke Frank knox became assigned to the "RoughRiders" where he became known to Teddy Roosevelt. He later supported him politically. Knox was away from the paper during the war and after it he was hardly ever returned. In 1936 he ran for the Republican presidential nomination unsuccessfully, but was named the Vice Presidential candidate. In 1940 he was appointed secretary of the Navy. In 1944 knox and Muehling died within one week of each other. See Norman Beasley, Frank Knox: A Short Biography, (Garden City NY, 1936).

Muehling's widow took no interest in the paper and allowed Knox's widow to sell the paper, and she settled on William Loeb, who was a third-generation German-American. His father, the son of a German immigrant had been private secretary to Teddy Roosevelt. Loeb's views were conservative and controversial. See Kevin Cash, who the Hell is William Loeb, (Manchester, NH Amoskeag Press, 1975), pp. 23-36, 33$50,103-111$.

German born Heinz Kaufman served in the Union-Leader corporation from 1961 to 1992 retiring as vice President for Operations. He was succeeded by Dirk Ruemenapp, born in Germany, who began working in the United states for the New York Times. He joined the Union Leader in 1972 as city Editor and Executive Editor before his promotion. New Hampshire Sunday News, October 11, 1992 .

The Manchester Union, Manchester Leader, and Union Leader are all owned by the same company since 1913 and published separately and then jointly. The New Hampshire sunday News is the Sunday edition published by the Union Leader corporation.

97 Manchester Union, April 5, 1917, Lawrence Telegram, April 5, 1917, Lawrence Evening Tribune, April 9.

${ }^{98}$ Lawrence Evening Tribune, April 9, 1917.

99 Lawrence Evening Tribune, April 14, 1917. 
100 Manchester Union, April 10, 1917. Joseph Hollrigl was the pastor of the Erste Deutsche Neue Kirche.

${ }^{101}$ Manchester Union, May 12, 1917. The Kreuz Zeitung was not further identified.

${ }^{102}$ Manchester Union, May 12, 1917.

103 Manchester Union, November 14, 1918.

${ }^{104}$ Kennedy, Over Here, 16-17, 102-03, 105-106. F. Luebke, Bonds of Lovalty, 14-15, 18-19.

${ }^{105}$ Lawrence Tribune, and Lawrence Telegram, April 6, 17, 20, 1918. German-American Albert Schaake, active in the Liberty Loan Campaign was marshall of the sixth division representing the B.P.O.E. The Tribune indicated that there were 35,000 participants in the event.

${ }^{106}$ Anzeiger und Post, April 20, 27, 1918.

${ }^{107}$ Lawrence Tribune and Lawrence Telegram, May 3 and 4 , 1918.

${ }^{108}$ Anzeiger und Post, May 4, 1918. Adolph St. Linger, worked as a designer for the Essex Company, and was previously the president of the Stadtverband, Lawrence Directory, 1916 and 1918. See above for his involvement in the 1915 neutrality meeting.

${ }^{109}$ Anzeiger und Post, October 12, 1918.

110 Manchester Union May $15,1917$.

111 Manchester Union, May 22, 1917.

112 Manchester Union April 16, 20, 22, 1918. Anzeiger und Post, April 20, 1917.

113 Anzeiger und Post, April 20, 1918.

114 Anzeiger und Post, May 26, 1917, Manchester Union, May 18, Anzeiger und Post October 1, 1918 and June 5, 1919. Among the 39 Turners in the military included were oskar $\mathrm{E}$. Dick and Carl H. Trumpold. Christ Presbyterian Church, 10oth. Anniversary Booklet. Manchester Union, June 2, 1919 reported on the Turn Verein event for its 60 members returning from military service. Maurice Dorgan, History of Lawrence, (Cambridge, Murray Press, 1924). Approximately 187 German names are on the list of those who served, and nine died in the service of the United States, pp. 233-34, 237267. In Manchester the names of those who died during the war appears to be unknown. The momument in Victory Park 
contains no names, and no records have been uncovered.

115 Manchester Union April 20, 1918. Anzeiger und Post April 27, 1918.

${ }^{116}$ L'Avenir Nationale, April $18,1918$.

${ }^{117}$ Robert G. LeBlanc, "The Franco-American Response to the Conscription Crisis in Canada, 1916-1918," American Review of Canadian studies, (Autumn 1993), 343-372. Many of the Franco-Americans in Manchester were citizens of Canada, and subject to military service there, but showed a lack of enthusiasm for the war. As non-citizens of the United States they were also not elibible for the American draft. There were accusations that they avoided service. They were, perhaps, exhibiting super-patriotism to overcome this perception. LeBlanc says that considerable numbers of Franco-Americans enlisted in the American military, but that exact numbers are not available.

118 Manchester Union April 20, 1918. Anzeiger und Post, April 27, 1918.

119 Manchester pirectory, 1918.

120 Manchester Union, May 8, 1918. It was reported that the defense had little time to prepre for the case. Anzeiger und Post, May 18, 1918. The Federal court is in Concord, New Hampshire.

${ }^{121}$ Manchester Union, May 9, 1918.

122 Anzeiger und Post, October 12, 1918.

${ }^{123}$ Anzeiger und Post, October 12, 1918. No other information was uncovered regarding Englehardt.

${ }^{124}$ The Taubert Case receives mention in: Walter Nelles, Espionage Act Cases, (New York, National Civil Liberties Bureau, 1918), pp. 84-89 and Zechariah Chafee, Free Speech in the United States, (Cambridge, Harvard University Press, 1941), pp. 74-75.

125 James J. Badal, "The Strange Case of Dr. Karl Muck, who was torpedoed by The star spangled Banner during World War I," High Fidelity Magazine, 20 (October, 1970): 55-61. and Alan Levey, "The American Symphony at War: GermanAmerican Musicians and Federal Authorities During World War I," Mid America, 71 (January, 1969): 5-13. He was a citizen of switzerland, a neutral country. 
${ }^{126}$ Anzeiger und Post, June 27, 1917, Manchester Union, September 11, 1918 .

${ }^{127}$ Anzeiger und Post, October 27, 1917. Lawrence Telegram and Lawrence Tribune, October 23, 1917. The Lawrence Opera House was not connected with the German community.

${ }^{128}$ Anzeiger und Post, November 10, 1917. In compliance with the federal law this announcement was in English. A short time later all articles were in German, with "true translations" provided to the Lawrence Postmaster.

${ }^{129}$ Manchester Union, November 25, 29, 1919.

${ }^{309}$ Anzeiger und Post, April 21, May 5, May 26, Sept 29, October 27, November 10, 1917, Nanchester Union, November 6, 1917.

131 Anzeiger und Post, March 2, 16, November 3, 1918.

${ }^{132}$ Manchester Union, May 6, 1918, Anzeiger und post, May 11, and September 28, 1918.

133 Anzeiger und Post, April 21, 1917, Lawrence Tribune and Telegram, April 23, 1917.

${ }^{134}$ Lawrence Evening Tribune, April 23, 1917. Manchester Union, May 26, 1917 .

135 Anzeiger und Post, June 16, 1917, Lawrence Telegram and Tribune, June 23, 1917.

${ }^{136}$ Anzeiger und Post, March 23, 1918, Manchester Union, March 25, 1918 .

${ }^{137}$ Anzeiger und Post, June 29, 1918, Manchester Union, June 23, 1918. Lawrence Telegram and Tribune, June 29 and 30 1918 .

${ }^{138}$ Anzeiger und post, August 24, 1918.

${ }^{139}$ Anzeiger und post, August 24, 1918.

140 Anzeiger und Post January 4, and 11, April 5, 1919.

${ }^{141}$ Anzeiger und Post, March 1, June 19 and August 2, Nov 23, December 13, 1919 .

142 Anzeiger und post, January 4, May 3, June 14, Aug 23, 1919.

143 Anzeiger und Post, September 6, 1919. 
144 Anzeiger und Post, December 6, 20, 1919.

145 Anzeiger und Post, July 19, August 30, Sepetember 6, November 22, 1919 .

146 Anzeiger und Post, German language, March 22, April 5, April 19; Prohibition, March 8, August 16; Immigration January 25, Sept 16, September 13; Germany and Peace, June 28. "True translations" of articles on Germany and peace negotiations were filed with the postmaster in Lawrence. 
CHAPTER VIII

BETWEEN WORLD WARS:

RE-EMERGENCE, REVIVAL, AND SLOW EROSION OF DEUTSCHTUM, AND A NEW CHALLENGE

Deutschtum in Manchester and Lawrence, hardly interrupted by World War I, remained vital during the 1920 s and 1930s. It appeared as strong and vibrant as ever. However, its vibrancy masked the ascendancy of the dominant American culture. Attempts to preserve German language and Iife were doomed. Nevertheless, fundraising activities, club life and events, German language schools and German church activities continued. Community concerns about post-war conditions in Germany soon gave way to a sense of pride in Germany, only to be replaced by concern and anxiety. Each phase in the attitudes and actions of the German communities deserve further analysis.

The continuation of the Allied blockade for seven months after the Armistice exacerbated war induced-economic hardships in Germany. Newspaper reports and letters from the Alten Heimat, tugged at the heart. Fund raising added a purpose to the routine Vereine events such as concerts, minstrel shows or theater, and dances. Through 1922, aiding the "old homeland," became the theme of club activities and benefit events. In both cities, special committees were 
organized to raise funds to alleviate suffering in Germany. Especially in Lawrence, the "benefits" continued to unite the Vereinsdeutschen and the Kirchendeutschen. In April 1920, a large benefit concert, in the Turnhalle attracted a large crowd, who came to hear the "German orchestra," the choir of the German presbyterian Church, the men's choir of the German Catholic Church, and the children's Sunday School choir of the German Presbyterian church. 1 In October 1921, the "Lawrence Benefit Committee" planned to raise funds for the American Friends Society (Quaker) relief efforts for German Children. The event brought together representatives of the major Vereine of Lawrence and the German Presbyterian and German Catholic churches ${ }^{2}$ The combined "German Children's Day" held in the Turnhalle to benefit the hungry children of Germany proved so successful that Pastor Lange, of the German Presbyterian Church, attempted to expand the "Children's fund" to Manchester. 3

In Manchester fund-raising efforts also united the churches and the Vereinsdeutschen. In october 1923, a bazaar at the Harugarihalle featured the Sons of Hermann, the Turners, the Presbyterian, German Lutheran, and First New German churches. 4 Meanwhile, the German Presbyterian church, under the direction of Pastor Kamm had raised considerable funds on its own since 1919.5 st. Raphael's, although it still contained German parishioners, had never really been a "German parish" and did not participate.

These special fund-raising efforts revealed again the 
Saxon origins of the German residents of the textile cities. In March 1920, the Anzeiger und Post reprinted an article from the Glauchauer Tageblatt, thanking the "former Glauchauers in Lawrence, Fitchburg, and New Bedford for the Christmas gift, which helped 241 families." 6 In early 1921, the same paper thanked the "former Glauchauers and friends in Manchester, whose Christmas gift helped 200 persons or families."7 Previously the "Ladies Benefit Committee of Manchester," had received a letter, printed in the newspaper of Eibenstock, saxony asking for assistance. 8 Additionally, officials of several saxon towns and cities wrote to the Anzeiger und Post requesting assistance. 9

By the end of 1923 attendance at the benefits seemed to decline. 10 waning interest and improving conditions in Germany were the likely causes. However, the benefits were important for several reasons. They started as soon as it was politically feasible to raise funds for Germany. Resilient German-Americans who had previously led the fund drives for the German Red Cross, then for Liberty Loans, now raised funds for German children. The benefits also continued to unite the Protestants, Catholics and Vereinsdeutsch in Lawrence and various protestant denominations with the Veriensdeutsch in Manchester. The benefits gave a boost to the local vereinsleben, which will be discussed further below, but our attention will first be turned to the re-emergence of the New England wide fests after the war. The New England wide meetings and 
festivals began in 1920 with Germans in Manchester and Lawrence playing important roles. In 1920, some three hundred singers from fourteen New England sangerbunde met in Lawrence. 11 Also in 1920, the Harugari Association held its New England meeting in Lawrence. 12 In 1921, Manchester attracted "hundreds of guests" to the city when it hosted the sangerfest of the New England states, with singers from eight cities participating. ${ }^{13}$ That the German-Americans would hold such meetings in 1920 indicates that they felt confident of their position in the community. Also it appears that there was little residual effect of the war in the larger community, which made no attempt to challenge, block or other wise harass German-Americans and their club activities. The annual New England meetings, competitions and festivals continued through the 1920s, 1930 s and into the 1940s. These events brought large numbers of visitors to the cities, which probably did not harm the local economy, and attracted the notice of local politicians and the press. For instance, in 1924, the mayor of Lawrence welcomed the over 500 persons attending the combined New England Turner gymnastics competition and singing festival. 14 At the 1933 Turnfest in Roxbury several prizes were donated by nonGermans, including two trophies by the mayor of Fitchburg, Joseph N. Carriere, one from Massachusetts Lt. Governor Gasper G. Bacon, and one from the Lawrence Eagle Tribune. 15 In 1937, the Manchester Union reported on the over 300 individuals attending the "twenty-sixth annual New England 
Turnfest."16 In addition to Manchester and Lawrence, the other New England cities with German populations, would host various Turnfeste and New England sangerbund Feste during this period. Groups from Manchester and Lawrence attended almost all of the festivals or competitions. 17

Several characteristics of local club life in Manchester and Lawrence deserve our attention. First-generation GermanAmericans continued in positions of leadership into the 1930s. Also, strong family involvement fostered the continuance of Deutschtum. Some individuals belonged to three or more Vereine, usually one of the major clubs, a fraternal club, a social club, a mutual benefit society, and possibly a church club. Additionally, the number of clubs remained relatively constant and large for the size of the German community into the 1940s. However, despite these indications of strength, it appears that the forces of Americanization were slowly eroding Deutschtum as expressed in Vereinsleben. In Lawrence the numbers of Vereine and their activities remained strong between the wars. In 1920 there were approximately thirty major clubs. By 1935 the number was about twenty-five, and this number remained the same until the start of the Second World war. Additionally, most of the major German halls stayed in existence. Weekly social events continued. For instance in mid-September 1936 one could attend Kabarett evenings in the Hermanns Hall or the Harugari Hall, a Bavarian Folk Fest at the Liederkaranz boat house, or a schlachtfest and dance to benefit the German School Society 
at the Eintracht boat house, or the Fifth Anniversary of the Concordia Social (Schutzen) club. Even in the late spring of 1942 there were weekly dances at the Harugari hall, the Central hall, the Turn hall, and the Bavarian hall.18

Likewise in Manchester, the number of Vereine remained relatively constant throughout this period. In 1920 ten major German clubs existed in Manchester. The Turn Verein gave its strength at about 500 and the "Workingmen's Relief Association" as 575. In 1930 the memberships were 1 isted as about 400 for the Turn Verein and 450 for the "Workingmen's Relief Association."19

During this period the Manchester Turnverein showed remarkable strength. Until the late 1920s Manchester Turners learned gymnastics from volunteer instructors. In 1927, the Manchester Turners felt both the confidence and the need to hire a professional gymnastics instructors from the Normal College of Gymnastics, a college for teachers of physical education, founded under the auspices of the American Turnerbund in Indianapolis. In 1927 Gerhardt Haase, became the first professionally trained instructor from the college, but he remained in Manchester only for a short period. In 1931, A.G. Robert Sandmann, also a graduate of the Normal College in Indianapolis, was hired by the Manchester Turn Verein, and under his auspices the Turners competed for a number of years in the New England competitions. The social life of the Turn Verein was apparently very good, with many in attendance. In 1928 between 600-700 attended their 
costume ball, and 340 children and 450 adults participated in the children's costume ball; in 1931 over 800 persons attended their minstrel show the first night alone. Unfortunately, disaster struck when the Turnhalle was destroyed by fire in January 1936. At the dedication of the new, larger Turnhalle in 1937, New Hampshire Governor Francis Murphy presided as the guest of honor. The new Turnhalle was the centerpiece of the 1937 New England Turnfest. Disaster almost struck again during the hurricane of 1938 when flood waters of the Merrimack River threatened the newly constructed hall. Working all night, dedicated Turners saved their investment. Despite adversities caused first by Prohibition, then fires and floods, the dedicated members of the Manchester Turn Verein kept the organization active and functioning. 20

In addition to the major clubs, the sons of Hermann, the Harugari Asscciation, a Schiller Lodge, and the German School Association continued to function in Manchester. Some of the smaller clubs experienced a decline in membership and importance. For instance, sometime between the end of World War I and about 1925 the various singing societies (e.g. Beethoven Munnerchor and Manchester Mannerchor) combined into the "unified singers" (Vereinigte sanger). The Vereinigte sanger participated in New England competitions through the 1930 s and 1940s. Also during this time the Bavarian club dissolved. 21

The dedication of first generation German-Americans and 
second-generation members from the same families explains much about the continuance of the Vereine during this period. The Manchester Turn Verein exemplifies an organization that was well served by the first-generation into the 1930 s and by the second-generation into the 1950 s and beyond. One such leader was Reinhard Hecker, born in Glauchau, Saxony. He emigrated in 1881 and obtained a job soon after his arrival in the Amoskeag. In 1896 he took over his father-in-law's store and in 1900 started what was to become the well-known "Hecker's store" on the West side. He served a term in the New Hampshire legislature and the Manchester "common council." Active in the Schiller Lodge of the Sons of Hermann he attended Massachusetts and national meetings as its delegate. In both 1930 and 1935 he served as "First Speaker," or president, of the Manchester Turn Verein. He died in 1936, but his son Gerhard served on the board of the Turn Verein in 1970. To cite another example, J. Adam Gebhardt, born in Bavaria, emigrated in 1883 and moved to Manchester in 1898. A volunteer gymnastics instructor for many years, he held the position of corresponding secretary in 1935, and wrote the clubs letters for a total of 30 years. He helped the Manchester Turn Verein celebrate its one hundredth anniversary. Gustav Boettcher, also born in Glauchau, immigrated in 1880 and worked for many years in the Amoskeag and participated in the Turn Verein. Son Erwin competed nationally and served on committees until the 1970 s. His son Erwin, Jr. won first place in the decathlon at the 
1931 New England Turnfest in Lawrence and remained active in the Turn Verein for many years. 22 Martin Moll, born in Hof, Bavaria, landed in New York in 1882. He worked as a salesman, and served as Manchester representative for the Anzeiger und Post for many years. During the 1920 s he taught at the German School. He was a forty year member of the Turn Verein, a thirty-seven year member of the Schiller Lodge, and was a member of the Harugari club and the Workingmen's sick Benefit society. His wife was an officer in the Natur Heil Verein (Natural Cure Society). At his death in 1929 he was still active in all of the clubs. 23

In Lawrence, also, many first-generation GermanAmericans kept the clubs alive. Among the most influential with a long tenure was Julius B. Emmert, born in Meerane, Saxony in 1872 he arrived in America in 1880, and later moved to Lawrence and founded the funeral home and chapel in 1895. From 1910 to 1930 he sezved the German Hospital Free Bed Society as its president. At the time of his death, in 1956, he was still active in the German Presbyterian Church. 24 Editor Max E. Trumpold belonged to several clubs and served for years as secretary of the Free Bed Society, a position he held at his death in 1929. Max Riedel, who emigrated in 1879 at the age of thirteen from Glauchau, saxony, officiated for many years as the "First Speaker" of the Turnverein, and sang for the New England Singers Union. Emil Beck, who in 1892 went from Silesia to Manchester and later to Lawrence, became president of the Eintracht singing society. Gustav Weigel, 
who emigrated from Saxony in 1880, managed the store of the former Konsumverein for many years. He organized the 1905 New England Singers festival as its Fest president and had been the president of the New England Singers Union. His brother acted as treasurer of the Turnverein. Oscar Arnold, who emigrated in 1870 at the age of ten from HohensteinErnstthal, Saxony, had been the "First speaker" of the Turnverein in 1920. Hermann Rippe, who emigrated from Bremen in 1899, held the position of president of the Lawrence steuben Society. He also belonged to the schiller society, the Workers Relief Society, and the German School. Arriving in 1922 from Saxony, Max Stoeher served as secretary of the Turner singers and a member of the German school committee. Louis Martin, from Meerane Saxony, helped found the Workingmen's club, the Turnverein, and the Lyra singing Society, In 1930, he served as president of the Waldheim society and treasurer of the Workingmen's society. Finally, August Fichtner, born near Munich and in America for 46 years, became the general secretary for the Massachusetts Society of the Harugari. 25

The interconnected and familial nature of the relationships between the clubs also explains their continued strength. Examples can be seen in the 1930 Lawrence Directory which listed forty-four different German clubs and their sub-sections. Carl Vogt served as president of the German School, the German Central Association, and the German cremation Society, and collector for the workingmen's sick 
and Death Benefit Fund and the Workingmen's Society. The Kliers served as officers in various clubs: John in the Harmonie Lodge and the Turner Sick Benefit Society; Fritz in the Eintracht Singing society; and George in the Arion singers. Rudolph Kuehn served as president of the steuben Society, Turner sick Benefit Society, and treasurer of the Turner Progressive Club. August Fichtner led both the Lawrence Comtueri of the Sons of Hermann and the Schiller Lodge. Louis Martin was prominent in the Waldheim $c l u b$ and the Workingmen's Society. Paul Melhorn collected payments for the German General Sick Benefit Society and the German School, while brother william Melhorn acted as the secretary of the Workingmen's Society. Gustave Pilsch's offices included secretary for the Brunhilda Lodge and treasurer of the Harmonie Lodge of the Sons of Hermann. Joseph Bernhardt president of both the Alsatian sick Benefit Society and the Combination club, kept minutes as secretary of the Lyra Singers, where George Bernhardt was president. The Muenzners held offices in the Turnverein; William and John as president and secretary of its sick Benefit Society respectively, and Mrs. Emma Muenzner as collector for the Turner's sisters society. Such connections indicate that a small number of individuals helped keep the clubs functioning. 26

In addition to the officers, some individuals held memberships in a number of different Vereine. Wilhelm Emmert, the owner of a Lawrence fish market, belonged to the 
Harmonie Lodge, the Turners, the German General sick Benefit Society, Concordia Rifle Club, the Glocke Singers, the German Central club, and the East Methuen German Hose Company. Amoskeag overseer Fritz Simon's memberships included the Barbarossa Lodge, the Worker's Sick Benefit Society, the Harugari club, the German Relief society, and the Overseer's club of the mills. In Lawrence, Georg Reitte, a weaver in the Wood Mills, belonged to the Alsatian Sick Benefit Society, the Schiller Lodge, the Turnverein, the Schiller Sick and Death Benefit Society, and the Elks. Adam Strobel, a weaver in the Washington Mills, had memberships in the Turners, Bavarian Reading and Progressive Society, the Harmonie Lodge, and the Vorwarts singing society. Working in the McElwain Shoe Shop in Manchester, Alfred Herder found time to join the Schiller Lodge, the Turners, the Workingmen's sick Relief Society, the Harugari club, and the United Singers. 27

Women showed the same pattorn of multiple membership. Bertha Strobel belonged to the Turnschwestern, the Brunhilda Lodge and the Central Society. Catherine Leinsing's memberships included the women's death benefit section of the Workingmen's sick Relief Society, the Turnschwestern, the benefit section of the Barbarossa Lodge, and st. Raphael's parish. Her membership in both the Catholic parish and the Turners is of interest. It indicates a lessening of the conflicts between the catholics and the generally "free thinking" Turners. Both organizations made some 
accommodations. Mrs. Selma Langer joined the Turnschwestern and the women's death benefit section of the Workingmen's Sick Benefit Society. In Lawrence Mrs. Mary Roth's memberships included Turnschwestern and the Edelweiss Lodge, and Mrs. Agnes Koehler was a member of the Brunhilda Lodge and the Turnschwestern. 28

How the German-Americans of Manchester and Lawrence supported the various clubs with both time and money remains unclear. In earlier times work days normally lasted for twelve or fourteen hours, leaving little time for activities. During the Depression, if there was work at all, the work hours were shorter. Consequently, wages were lower, and it was harder to find funds to support dues and entrance fees. According to one couple, when they had a young family and a new business, "they did not attend much."29 on the other hand, some individuals must have felt safer with their funds spread among several sick and death benefit or mutual aid societies. Also, membership in several clubs gave them more of an option of picking and choosing among the halls and events they wished to attend.

At the same time the "German-ness" of certain clubs was beginning to decline. The Manchester Turn Verein began to admit non-Germans in the 1930s, and the prize lists at the New England Turnfeste showed non-German names. For instance at the 1931 Feste in Lawrence, George Dupont won for Manchester and Genevieve Loeffler won a prize for Lawrence. At the 1937 meet in Manchester the winners from Lawrence 
included Ella Malcom, Lillian Laffert, and Evelyn Wilson. 30 Whether this is the result of intermarriages between Germans and non-Germans or the admittance of non-Germans cannot be precisely explained. (The subject of intermarriages will be explored more below). In 1935, at the sixty-fifth anniversary celebration of the Manchester Turn Verein, president Oscar Lein gave his speech on the history of the club in English. The Turnverein one of the strongest bastions of Deutschtum, was showing strains.

Like the Vereine the German churches showed signs of change, but, perhaps, succeeded more in preserving German culture and religion. Furthermore, Gordon considers that ethnic churches were the most successful of immigrant organizations in preserving language and culture. 31 Maxine Seller also believes that to the immigrant the ethnic church increased its importance and became the the bearer of the language and culture. But, according to seller, the churches also changed in America. 32 Moreover, according to Niebuhr the churches would eventually give in to English to maintain members. 33 The German Presbyterian Churches in both cities attempted to maintain German worship, culture, and language. In both Manchester and Lawrence the German Presbyterian Congregations remained the largest and most powerful denominations, having among their members many of the leaders in German business. For instance, Max Trumpold, and Julius Emmert were members; and the Sch bnland, Melhorn, and Simon families in both cities belonged. From the available 
membership lists and published obituaries, the Presbyterian denomination was the largest among church-going Germans in the two cities. 34

The Presbyterian Churches exerted influence through a willingness to become involved with both the vereine and the Catholic Church, especially for fund raising for Germany. Their role in the Deutsche Woche of 1916 and the fund raising efforts after the war has has been noted. The willingness to be involved with the Vereine, or the broader German community, is demonstrated by the fact that the Lawrence German Presbyterian Church often contributed the most of any German organization to the German School Association. 35

The German Presbyterian Churches became a neutral church for church-going Germans who may have been of different faiths. This tended to increase its membership. Marriages in the German Presbyterian churches suggesting unions of different religions include: Adam Gemeinhardt of Austria and Martha Babel of Germany (1895), Rodney Griffin of New Hampshire and Lydia Melhorn of Saxony (1902), Max Oettler and Augusta Rosler, both of Bavaria (1902) and paul Melhorn of New Hampshire and Martha Woulters of France (1921).36 More recently, in 1932, Herbert Paul, a Catholic from Westphalia, and Helen Schroeder, a Lutheran from Silesia, were married by Pastor Kamm and joined the German Presbyterian Church. 37

Long term ministerial and lay leadership helped the German Presbyterian Churches maintain their influence. In Manchester, the congregation elected Swiss born John Kamm 
pastor in 1900, a position he was to hold until his death in 1935. In Lawrence, Richard Lange, born in Posnen, assumed the pulpit in 1906 and served until his retirement in 1939. One of the founders of the Lawrence church, German-born Frederick Veitor, taught sunday school from 1876 to 1927.38 These pastors and the sunday school instructor tried to maintain German language, culture, and services in the churches. They were somewhat successful, but had to bow to the inevitable. The Lawrerce church began a service in English in 1939, while in Manchester an English service was regularly scheduled in 1932, as many of the younger members could not understand German. 39 Both pastors led youth groups to foster both religion and the German language. Pastor Kamm, as secretary of the youth group, recorded the minutes in German. There is evidence revealing that he transcribed these from notes kept by one of the young members, since stuck between the neatiy lettered record book pages was a piece of paper with the minutes written in English. 40

The above indicates the futility of the efforts to maintain the German 1anguage. Nonetheless, a variety of institutions, of the church and its youth groups, the German School, ard the Anzeiger und Post regularly deplored the fact that most of the American-born children of Germen parentage did not learn German. The Anzeiger und post in particular championed the cause of the German language, as the greatest language of culture, Luther and the great German writers. The paper quoted the presidents of Columbia and Brown 
University and professors at Harvard on the value of German, and the need for German instruction in high schools. In an article printed in English, the Concord society a national group dedicated to preserving German language and culture, traced German in the United states to colonial times and noted that George Washington spoke German, concluding that German had the same cultural rights as English in America. Parents were exhorted to teach German to their children. The Anzeiger und Post accepted that children would learn English, but endorsed advice from a R. Bbmer of New York ("Vergesst die deutsche sprache nicht!"), that it was possible and quite easy for children to learn two languages. More pointedly, an article by a willy J. Knofel warned that the the German press needed new readers. "Deutsch oder English in deutschen Verein" discussed the issue of the language spoken in the clubs, concluding that the German language was the foundation of the clubs. The article stated that those whose mothertongue was German had a moral right to speak it, and that it should be clear to the children that German would be spoken in the club halls. 41

Appearing before the start of each semester at the German schools the editors hoped to boost enrollments. The paper also gave much space to the activities of the German schools, but from both the tone of the articles and the successes of the schools it would appear that maintenance of German was a lost cause. Supported largely by the local Vereine, the German schools of Manchester and Lawrence 
continued to offer instruction. 42 students were expected to pass semi-annual tests of proficiency. In 1917, perhaps an omen of things to come, and perhaps an indication of the appeal of the schools to non-Germans, Madeline Flaherty become the first non-German to win first prize in the annual contest of the Manchester school. ${ }^{43}$ Typically, classes were held in the late afternoon or early evening, or on saturday morning. As might be expected, such a schedule was probably not very popular with children. The number of children attending the schools gives a clear indication that the maintenance of the German language became increasingly difficult.

TABLE 8.1

ATTENDANCE AT THE GERMAN LANGUAGE SCHOOLS 44

YEAR LAWRENCE MANCHESTER

$1914 \quad 120$

$1916 \quad 207$

$1917 \quad 200$

$1918 \quad 167$

$1921 \quad 108$

$1926 \quad 70$

1927

1929

1930

1932

1933

1935

1936

1937

81

112

116

120

108

109

108

146

75

57

Source: Anzeiger und Post German School Reports for the years given.

The increase in attendance in 1916 and again in 1930 resulted from a renewed interest in Germany brought about by World War I and the Nazi rise to power. Despite that, it is obvious 
that not all children born of German parents were attending the German School and that the numbers were not sufficient to maintain the language. Children in both cities attended public schools where the instruction was in English, and only in Lawrence was German offered as a foreign language course in the high school.

The educational experience of Harold G. Dick (b. 1906) illustrated the trend. His grandfather was Ernest August Dick and his great uncle was Hugo Dick, co-publisher of the Anzeiger und Post. Both were born in Saxony and active in Vereinsleben and Deutschtum in Lawrence. His father, Ernest otto Dick was born in America and was treasurer of E.A. Dick \& Son Builders, and was also active in Lawrence's Deutschtum. Harold Dick entered M.I.T. in 1924, and upon graduation he obtained a position with Goodyear-Zeppelin company and worked directly with the zeppelin company in Friedrichshafen, Germany. 45 Given his background one might assume that he could speak German. He realized that it was "desirable that I should learn to talk their language," but he had only "two years of German in high school in Lawrence, Massachusetts (my teacher's name was O'Leary)."46 By his own admission "language was not his cup of tea," and he spoke German with a combined "New England and Schwabisch" accent. 47

Marriage outside one's ethnic group is considered to be a clear indication of the breakdown of ethnicity. 48 In the 1920 s and 1930 s there is evidence that the Germans in Manchester and Lawrence were more prone to marry outside of 
their ethnic group. Elizabeth o'Leary, mentioned above, lived very near to or in the "Dutch gap." Likely she illustrates this trend, and she was possibly of mixed German and Irish parentage. 49

over time the liklihood of Germans marrying non-Germans increased. Evidence of increasing intermarriages can be seen in the Marriage Records of Manchester between 1880 and 1936. Between 1880 and 1900 most marriages took place between individuals born in German speaking areas of Europe (e.g. Germany, Austria and Bohemia, Switzerland, Alscace, etc.). There were practically no marriages outside the linguistic/ethnic group. Between 1901 and 1920 the number of marriages with non-Germans increased, with the pace accelerating between 1915 and 1920. This trend continued between 1921 to 1936, when it became 258 of the total marriages. As would be expected the largest number of spouses were selected from the Irish, French Canadian, and English stock of New Hampshire. 50 Details are given in Table 8.2. Access to the Lawrence city records was not possible, but that the results were likely to be similar can be seen from the Marriage Records of Mariahimmelfahrt. Between 1919 and 1942 there were 82 recorded marriages, or 164 possible partners; 38 of whom were non-Germans, or 23.17\%. Germans most often married the Irish, of whom twenty-four were selected for a spouse. 51

Ruby Jo Kennedy conducted a classic study of ethnic intermarriage rates in New Haven, Connecticut. In comparison 
to Germans in New Haven, Germans of Manchester were much more likely to marry within their ethnic group. In 1930 the New Haven "in-marriage" rate by national origin for Germans was $39.848,52$ whereas in for Manchester it was closer to 758 . The small and closed nature of the Manchester's German Community likely resulted in fewer intermarriages. Additionally, the visits between Manchester and Lawrence and the festivals in various cities helped in locating suitable German spouses. Between 1900 and 1936 Manchester's GermanAmericans married German-Americans from Lawrence and the other cities on the Fest circuit 59 times. 53 while a low percentage of the total, it helped maintain ethnicity. overall, there was a clear trend toward intermarriages. This could be expected since the children attended public schools and avoided German classes. The churches and their youth groups provided the last guaranteed places to meet a potential German-American spouse. 
TABLE 8.2

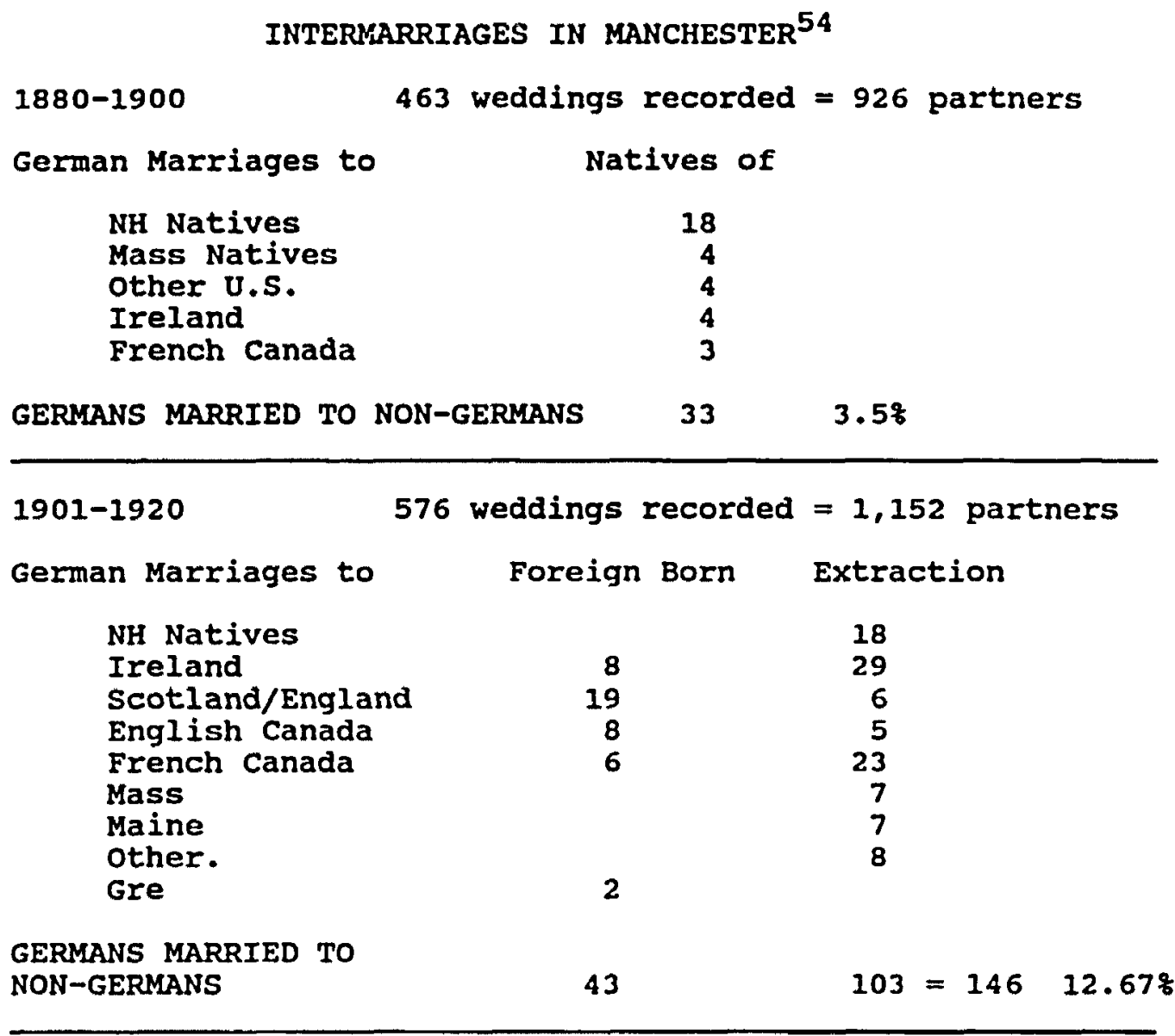

1921-1936 (May 5) 406 weddings recorded $=812$ partners

German Marriages to Foreign Born Extraction

ME/Mass

Scotland/Eng

English Can

French Canada

Greece

Italy

Sweden

Poland

Syria

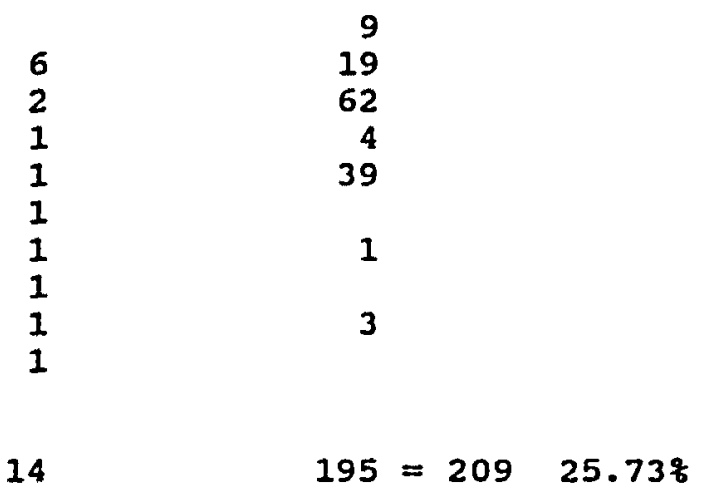

GERMANS MARRIED TO

NON-GERMANS

14

Source: Manchester Marriage Record Books, 1880-1936

329

Reproduced with permission of the copyright owner. Further reproduction prohibited without permission. 
On the other hand, non-Germans who married Germans sometimes assumed German ethnicity. The strongest indications are among those who joined Manchester's German Presbyterian Church. The Handschumacher and Melhorn families had been long standing leaders in the Church, so when Frederick Handschumacher married Helen Pollard, and Paul Melhorn married Julia Woulters, both spouses later became leaders of the German Presbyterian Church and active in the clubs. Hilda Handschumacher married Louis Ryan in the German Presbyterian Church, and he became active in the church. 55 In Lawrence, Dorothy Campbell married Julius Emmert, and she became active in the German Presbyterian Church, secretary to the Altenheim, and active in two other German societies. 56 In 1935, Eugene Daley married Anna Bernhardt, daughter of the founder of the Concordia Schützenverein, and the Daley family has remained active in the club to the present. 57

German Day activities fostered ethnic identity. Important issues surround the revival of these festivals. The number of German-Americans attending gives an indication of German-American attitudes about ethnicity and Americanization. Started again in the early 1920 s they were welcomed as a way to reaffirm pride in being German-American. As World War II approached concerns over mixed messages surfaced. Could they celebrate German pride and avoid being labeled Nazis, and could they convince others of their loyalty?

Lawrence organized a German Day celebration in August, 
1923 at old Orchard Beach, Maine, with between 600 to 700 people attending. 58 It must have been an accomplishment to get so many people to travel to Maine. However, the attendance represents only between ten and twelve percent of the first- and second-generation German-American population $(5,643)$ of Lawrence, and it was considerably less when the third-generation is considered. This proportion likely represents the committed core of German-Americans in Lawrence.

In 1919 German-Americans in Lawrence had organized the Carl Schurz 59 chapter of the steuben Society, which became the new national organization dedicated to building pride in the achievements of German-Americans, 60 In December, 1927 the local chapter organized an elaborate "Steuben Remembrance Fair." More than three hundred persons filled the Turnhalle for the event. Mayor Walter Rochefort paid homage to General Steuben and his contributions during the American Revolution and praised the German-Americans of Lawrence. Professor Claude Fuetz of Phillips Andover Academy recounted the history of von steuben, reminding the audience that the great Saxon general had landed in Portsmouth, New Hampshire. The last speaker, Eliot Wadsworth, Irom Boston, informed the listeners that in 1740 German settlements stretched from Georgia to Maine. 61 In 1930, over 400 people celebrated von Steuben's two hundredth birthday. Lawrence's Mayor Michael Landers welcomed the celebrants to the Turnhalle and praised the German-Americans for their contributions to the city. 
Frau Marie B. MacDonald, a well known official of the Nordamerikanischen Turnerbund, and the publisher of "The steuben News" told the listeners that the steuben Society would restore pride in being a German-American. 62

German Days in Manchester were more subdued. In December 1938, a German day was held in the Harugari Hall involving most of the clubs of Manchester. Judged to have been "very successful" German Day its proceeds vent to support the German School. 63

Capitalizing on the increased interest in remembering Germans, the Anzeiger und Post suggested a national holiday to honor German-Americans. When President Roosevelt praised the contributions of General Pulaski and the Poles to American independence, the paper asked why there was not a "Steuben Day?"64 In several other issues it called for a German holiday to maintain the respect of the Germans and to gain the respect of other American groups, for GermanAmerican contributions to the United States. 65 It also endorsed the concept that German Day was "for all Americans."66 However, with the increasing world tensions and concern about the activities of the Nazi German-American Bund a national German Day holiday was not possible in the late 1930s. That the editors pushed for it indicates a certain naivete on their part.

Despite an idyllic setting in Maple Park, Methuen, the activities of the Nazi Bund intruded upon the 1938 German Day celebration. The festival speaker, Friedrich Kreutzer, gave a 
rather long speech, in German, recounting the contributions of German-Americans to the nation especially during the Revolutionary and Civil Wars. He noted that Theodore Roosevelt, to whom he attributed German heritage, said that Germans were the backbone of the Republic. He exhorted the listeners to fight nativism and not to lower themselves to the level of English civilization. He then emphasized the patriotism of the German-American, who do not live in "the land of their fathers, but in the land of their children; and who are Americans." 67 The speaker then interjected in the middle of his speech a section taken from an unidentified "English newspaper," which he read in English. It opposed the efforts of Fritz Kuhn and the German-American Bund to unite German-Americans. The article stated that Kuhn's group wished to negate the melting pot. Furthermore, no one German-American organization "would form for...the vast numbers of the sons of immigrants-and those who are immigrants themselves--do not care to be mixed in political movements. They are Americans and prefer to vote and act as such."68 Just as in world war $I$, when the German-Americans did not join Germany but remained loyal to America, the same would happen now. "These men are not now going to abandon their Americanism to promote a cause across the seas. They are Americans and [will] remain so."69 Events across the seas were once more intruding on the local festivities and their Deutschtum and had been doing so for some years. Ironically, this time the siren song of world-wide German 
Volk, of which the locals had no interest, was ultimately going to destroy their Deutschtum.

Disillusionment, disappointment, and fear characterized the feelings of many Americans during the 1930s. The Nye Committee investigations reinforced suspicions held by many regarding the reasons for American involvement in World War I. The perceived unfair treatment of Germany under the Versailles Treaty and the failure of England to grant Irish self rule without a fight united the Irish- and GermanAmericans once more. 70 German-Americans sympathized with their ancestral homeland that had suffered defeat, partial occupation, hunger, inflation, political turmoil, and unemployment. Moreover, the Depression created massive unemployment and dislocation in the United States. Unemployed World War I veterans marched on Washington to demand prepayment of a bonus and were forcibly removed by the army from their tent city. Such conditions bred demagogues such as Father Coughlin, Huey Long, and others who promised solutions and gained support. Fascist groups such as the Silver Shirts and the Khaki Shirts were organized by and attracted non-Germans nembers. 71

Hitler's rise to power presented a dilemma for GermanAmericans. Initially, his appointment appeared legitimate, and he appeared to be restoring pride and power to Germany. His rise also increased interest in Germany. Therefore, many German-American leaders were reluctant to criticize nim. 72 Furthermore, the Third Reich generated interest and 
admiration from a number of non-German leaders in America, and some Congressmen were sympathetic to Germany's economic and foreign policy actions. 73 However, German-Americans were facing the old dilemma: "caught between a desire to support Germany and a desire not to be considered un-American once again. 174

The stance of the German-language press during the $1930 \mathrm{~s}$ resembled a flock of ostriches. According to historian Carl wittke the newspapers "tried to avoid the issue and to maintain an American isolationist policy."75 In 1940, Fortune Magazine discovered that "only once in seven years had the Neue Yorker staatszeitung published an article in strong criticism of Hitler's Program.... The rest of the time it has confined itself mostly to silence."76 However, the Neue Volkszeitung, a New York Socialist paper, was extremely anti-Nazi. 77

For a time the Anzeiger und Post appeared unable to make up its mind, but, in the end its record was better than that of the Neue Yorker staztszeitung. ${ }^{78}$ Showing its ambivalence it also reprinted articles from both the New Yorker Staatszeitung und Herold and the iveue volikszeitung. Initially it printed stories favorable to the National Socialist government and stressing the legitimate appointment of Hitler. It proudly announced its subscription to a wire service to get the latest news, "Our cable connection to Germany," (Unsere Kabelmeldungen aus Deutschland), "copyrights by Transocean." through which it reported news. Otherwise it 
carried local and national news shorts and articles on German Day or the German Language.

Early on, the paper must have had some concerns about Hitler and the growing power of the Nazi Party. In December 1931, it reprinted an article by Professor Oscar st. Michael of Philadelphia on "Hitler's ideas." The professor believed that Hitler and his party would soon come to power and that Germany would be better off for it. But, according to the professor, "no one in Germany believes in a revolution....Hitler would not rule alone, and...he would rule through the bureaucracy."79 Such a view made Hitler appear to be just another politician.

In fact that is how the editors treated him upon his assumption of power. It its March 11, 1933 issue it wrote of "Germany and Hitler:"

Adolf Hitler must now show the German people that he deserves their trust in his leadership. It does not depend on what roll he plays with von Papen or Hugenberg or his own people, but on the success he has on delivering on his promises, whether his government will stand or fall.... He has himself said that his success will be measured on these four years. He has the majority of the people behind him, he can go to work unhindered. 80

However, the editors of the Anzeiger und Post were not the only ones fooled by Hitler, and perhaps they had misgivings, since the very next issue carried the news of the dismissal of the mayors of many cities, including Konrad Adenauer of Cologne. 81 on March 25, the paper reported that "Germany has now become a dictatorship," 82 through a vote of the Reichstag. One week later, the paper also informed its 
readers in a lengthy article of the boycott of Jewish

businesses in Germany. 83 Two weeks later it followed with a not entirely complementary column entitled "What is Happening:"

The beautiful Adolf is sitting as chancellor in the Wilhelmstrasse. Berlin admirers shout to him, 'Show them, Adolf, what you can do' The German people have already endured so much, but never were they presented such a mysterious person as Adolf Hitler for their leader. 84

After a biography of Hitler, the author indicated that

Hitler's support came from youth who are;

...trying to find in him the leader who will lead to the promised land where milk and honey flow. He has promised it to them and now he must demonstrate that he can fulfill it.

What Hitler really wants is a mystery. He has proclaimed that he will carry out his plans within four years. But as yet nothing is known about the details. He calls his party the National Socialists. It may be nationalistic but is certainly not socialist.....Hitler... belongs to the right-wing parties. That he is recognized as such is obvious in that the German Nationalists support him. Much money comes to him from the great industrialists... to help him run his campaign and pay his private army, the "brown shirts." ... The industrialists know what they are doing when they see the great Hitler as a helper of big business. Maybe Hitler does not realize it, but his... feeding the people with patriotic and bragging cliches, work against the changes that should be made to help workers in the modern economy. 85

By reprinting this article the editors showed a moderately critical attitude. Yet they exhibit an ambivalence, perhaps because Hitler was the leader of their spiritual homeland. The Anzeiger und post demonstrated its ambivalence in July 1934, when it printed a letter from a local college student explaining the "Night of the Long Knives." During 
the night of June 30, 1934, Ernst Roehm, leader of the Brown Shirts (SA) and one of Hitler's earliest associates, dozens of other SA leaders, several other enemies of Hitler, and two military officers were rounded up and shot. Hitler gave the order for the action. West Andover resident Clara Duemling, on an exchange program to Munich, wrote her mother in support of Hitler's actions. She advised her mother not to believe the reports in the foreign press about Germany since they were not true. She said that Hitler had acted decisively, bravely, and quickly to end a conspiracy which was about to destroy the country. She reported that the conspirators were all shot including General Schleicher, who, she wrote, was chief among them. In her view the great majority of German people supported Hitler in ending the conspiracy. The editors said that they were presenting the letter, which had also appeared in the Lawrence Eagle and Tribune, but that it did not mean that they agreed or disagreed with its contents. 86 However, by reprinting the letter the paper gave credence and perhaps tacit support to its opinions, and the editors appeared to be sitting on the fence.

However, the Anzeiger und post quite emphatically declared that there should be no Reichdeutsch politics in America. It reported that the party politics of Germany "do not belong in this land."87 In october 1937 , it summarized on the front page the sentiments of william seabrook, from The American Magazine, that the Germans "were Americans." 88 Seabrook further concluded that among German Americans their 
opinions regarding "Hitlerism" are "70 percent indifferent, 20 percent anti-Nazi, 9 percent pro-Nazi in a sense consistent with loyalty in the U.S.A., and one percent, or less, rabidly, militantly Nazi in a not nice way." 89 In 1938, both Lawrence's German Day speaker and the Anzeiger und Post felt it important to challenge a manifestation of Reichdeutsch politics in America, the German-American (Nazi) Bund. 90

The history of the German-American Bund has attracted scholarly attention principally from Sander Diamond and Susan Canedy. 91 Both conclude that Germans, mostly from Baden, Bavaria, and württemberg, who had emigrated after World War I joined the Bund. 92 German Ambassador Hans Heinrich Dieckhoff reported that in "Chicago there were 700,000 of German descent... of these 40,000 are members of clubs of a German character, and only 450 [are] in the German-American Bund."93 The ambassador felt that this ratio was representative of the rest of the country. ${ }^{94}$ If so, the Bund was much more successful in calling attention to itself than in attracting members.

What then was the success of the Bund among GermanAmericans in Lawrence and Manchester? According to Diamond, the "Eastern Department" of the Bund included all six New England States. 95 This conclusion is based on information the Bund supplied to a Congressional Committee, and it was probably exaggerated to make the Bund appear strong. According to Canedy the "Eastern Gau" based in Yorkville, New 
York included branches in Boston, Bridgeport, Danbury, Grenwich, New Britain, New Haven, Warwick, Stamford and Waterbury, connecticut, and one in Providence, R.I.96 This list does not include Manchester and Lawrence, and there are no indications of active Bund chapters in either city.

Given the tenor of the times the legislature of Massachusetts decided to find out if the Bund operated within the state. It formed a special legislative commission to investigate "Communistic, Fascist, and Nazi Organizations."97 It devoted most of its time and report to the communist challenge. The commission felt a need to address its German residents in a positive way and it:

pays tribute to those American citizens of the German race who have helped to maintain our Commonwealth under the ideals of freedom and tolerance. Any portions of our report which deal with activities or purposes of persons or groups of German blood which are contrary to the ideals stated above apply only to those persons or groups, and in no sense the majority of our citizens of German ancestry 98

The commission found evidence that Kurt Luedecke visited or lived in Brookline, Massachusetts, a suburb of Boston, in 1932.99 Luedecke apparently started an anti-Jewish newsletter and formed a chapter of the Swastika League. Walter Kuhring, president of the League of German Veterans in the Jamacia plain section of Boston, was one of the signers of the Swastika League petition. He disavowed Luedecke, but his organization included the swastika as part of its symbol and excluded Jews from membership. In Massachusetts a branch of the Stahlhelm exsisted as a German war veterans 
organization, and its connections to the German National Peoples Party in Germany are not clear. However, after Hitler came to power the organization in Boston split in two, and the League of German War Veterans ("German Legion") and the German and the Austrian War Veterans of the U.S.A. formed. The latter organization had a unit in the Roxbury section of Boston. The German and Austrian War Veterans group had 50 or 60 members of which $90 \%$ were American citizens, and it accepted Jews as members. 100 According to Diamond, in 1936 the German-American Bund absorbed stahlhelm units in the United States, since the Stahlhelm had already been taken over by the Nazis in Germany. 101 The Massachusetts Commission confirms this by concluding that the "German Legion" (or League of German war Veterans! branch of the stahlhelm was a Nazi organization. The swastika formed part of its emblem, it refused Jews as members, and it claimed to take orders from Germany. On the other hand, the Commission absolved the German and Austrian War Veterans of Nazi connections. 102 The Commission also stated that a German Legion uni Exisicea in Lawrence. 102 l'ne Lawrence Directory of 1935 listed a unit of the German and Austrian War Veterans. 104 There appears to be no surviving records of this group, and no surviving evidence of the German Legion. Diamond's assessment that members of the Bund were typically from Bavaria, Baden and württemberg, if correct, means that there were few potential recruits in Manchester and Lawrence where few natives of those Lander lived. The Commission 
investigated rumors of Bund camp for children in the vicinity of Worcester and found no evidence of any Bund or Nazi camps have operated here. The Commission found that "newspapers and magazines in support of the Nazi regime in Germany come into this Commonwealth [from Germany] in considerable quantities."105 That some German-Americans in Lawrence and Manchester may have favored the Nazi regime is possible, but there is no evidence of any organized Bund units or activities in either city.

Any discussion of the Nazi era must consider relations between the German and Jewish communities. Beginning around the turn of the twentieth century, Jewish communities developed in both Lawrence and Manchester, with the former being both larger and more German while the latter was apparently more Russian. 106 on occasion the Anzeiger und Post mentioned Jewish news or issues. In 1903, the paper carried a front page article on the "hatred of the Jews in Russia" and provided information about the "pogroms" taking place at that time. 107 In 1911, the paper reported on the opening of the now synagngue in Manchester 108 In 1910, in one of its articles opposing immigration restrictions, commented that among the immigrants, "the Jews had been very successful."109 The paper's attitude toward Jews had been positive.

In Lawrence, the Jewish community, led by German Jews built two synagogues and established a Y.M.H.A. and a Y.W.H.A.110 There are no surviving membership lists which 
would indicate if any of these individuals were members of the German clubs. In 1935 the Associated clubs for the Y.M.H.A. building fund held its fourth annual Black and white Review in the Lawrence Turnhalle. The program booklet contained advertisements in both German and Hebrew for German and German-Jewish stores, among the latter was Izzy Goldberg's Racket store. 111 In November 1936, the Hebrew Ladies Free Loan Association, presented a performance of "The Lacht Nacht," (sic) at the Turnhalle. 112 Little information regarding Jewish club functions survives in Lawrence. It is known that the Lawrence Chapter of the Senior Hadassah held its events from 1936-41 in buildings other than those of the German clubs. Whether they had always done so is not known. And it is not known if the groups which had been holding events in the Turnhalle moved elsewhere.

The story of Julius Stern, illustrates the interconnectedness of the German and Jewish communities, even for a refugee from Nazi Germany. Born in Westfalia, Germany he was 16 at the end of World War $I$. He received a degree in busiñess aüministration ana economics from the university of Cologne, and after earning a Ph.D. in economics, he worked for a number of German banks. Upon the request of father-inlaw he took over operations of the family cotton yarn and hosiery business, whose main market happened to have been Chemnitz, saxony. He and his family continued to feel that they were not in danger in Germany but finally escaped in 1937.113 He resettled in Lawrence and met with anti-Semitism 
from the non-German realtor. 114 He rented space in the Everett Mills and restarted a hosiery knitting company, and he found a spinning mill in Lawrence "whose manager was of German descent," 115 and who made the sample yarn for him. Ironically, in 1943, while returning from a ski trip to New Hampshire he was arrested and held for two weeks in Boston as an enemy alien, because he did not have a travel permit that he had been told by officials he did not need.116 This prompted him to become an American citizen in 1944. However, he returned to Germany after the war to reclaim the family business and restart the mills there. 117 This undoubtedly makes stern much more unusual than most of the refugees from Germany. Julius Stern, although a Jewish refugee from Nazism, clearly identified with Germans and German-Americans.

\section{Conclusion}

Not only did Deutschtum in Lawrence and Manchester not die during World War $I$, it continued with new energy during the 1920s and 1930s. Vereinsleben continued, at first reinvigorated by the need to raise funds for the defeated Germany, andi tinen as a sociai and cuicurai means ố expressing Germanness. The Vereine lasted into the 1930s due to the continued leadership of first-generation German immigrants. Second-generation members of the same families as the original leaders stepped in to keep the clubs operating even longer. Despite these successes, the strength of language and culture was waning. The second- and thirdgenerations attended public school, where the instruction was 
in English and the exposure was to American popular culture. German Day and other events attempted to bolster or restore pride in German language and culture and in contributions of the German immigrant to the United states. Not only was German food served, but after 1933 beer as well. However, a telling report to the Deutsches Ausland-Institut, classified the attendees as "part-time Germans," [who] attended clubs and organizations from the old country on Saturday or Sunday, but on Monday morning they were American again."118 The reporter was very perceptive. The events, which were ways to enjoy German culture, were attended by a small percentage of the German-American community, and even those who attended were Americans.

Between the wars Germans could again take pride in the old homeland. Other immigrant groups, beside the Germars, also felt pride in their ancestral homelands. The Irish, Poles, Czechs, and others felt proud that their homelands now free and making progress. Germany, defeated, and plagued by inflation, joblessness, and political instability, seemed to be re-emerging as a stable political and economic nation. A sense of pride in Germany and a sense of misgiving about her government existed side by side. Finally one had to choose, and either through conviction or indifference, the choice was to eschew German politics. There was but one choice. The German-American residents of Manchester and Lawrecne were Americans, either by citizenship or by birth. 
The call from Germany for a "German People" (Volk) was much stronger than the call had been during world war $I$. It was a siren song that the German-Americans of Lawrence and Manchester would ignore. The wise sailor who ignores the song of the Lorelei passes the danger safely. However, even when it ignored the call, Deutschtum in Lawrence and Manchester could not be saved. The the next war would all but destroy Deutschtum. 
CHAPTER NOTES

CHAPTER VIII

${ }^{1}$ Anzeiger und Post, April 3, April 17, 1920. Attendance was not reported. Ticket prices were 25 and 50 cents, and ticket sales were $\$ 354.75$. If all tickets purchased were general admission attendance could have been 1,419 , if all were reserved seats it could have been 709 ; and if about half and half about 946 .

${ }^{2}$ Anzeiger und Post, October 1, 15, 1921. Among the Vereine paticipating and attending were the Turnverein, Bavarian Reading and Progessive Society, Sons of Hermann, and Iisrugari Lodge.

3 Anzeiger und Post, October 20 and $27,1921$.

${ }^{4}$ Anzeiger und Post, October 20, 1923, the bazaar raised about $\$ 755$;

${ }^{5}$ Anzeiger und Post, May 17, 1923, the Presbyterians alone had collected $\$ 311$. They had been raising furds for German relief since 1919.

${ }^{6}$ Anzeiger und Post, March 20, 1920, the article was February 21 in the Glauchauer Tageblatt.

${ }^{7}$ Anzeiger und Post, February 20, 1921 carried an article from the December 23, Glauchauer Tageblatt.

${ }^{8}$ Anzeiger und Post, August 14, 1920.

9 Anzeiger und Post, March 5 and 12, 1921.

${ }^{10}$ Anzeiger und Post, December 1, 1923. At the benefit in November, 1923 only $\$ 125$ was raised and only slightly more than 400 attended. 1920.

${ }^{11}$ Anzeiger und Post, May 22, August 7, and September 11,

12 Anzeiger und Post, August $21,1920$.

${ }^{13}$ Anzeiger und Post, August 21,1921 . There were at least 105 performers; August 21, 1920 .

${ }^{14}$ Anzeiger und Post, July 12, 1924 , 


\section{${ }^{15}$ Anzeiger und Post, July 24, 1933.}

${ }^{16}$ Anzeiger und Post, July 10 and 17,1937 and Manchester Union, July 5, 1937. Another example of the community noting the event is that the Lawrence Eagle-Tribune supplied the pictures of the event that appeared in the anzeiger und Post, July 11, 1931.

${ }^{17}$ A representative sample of the meetings or festivals is given below.

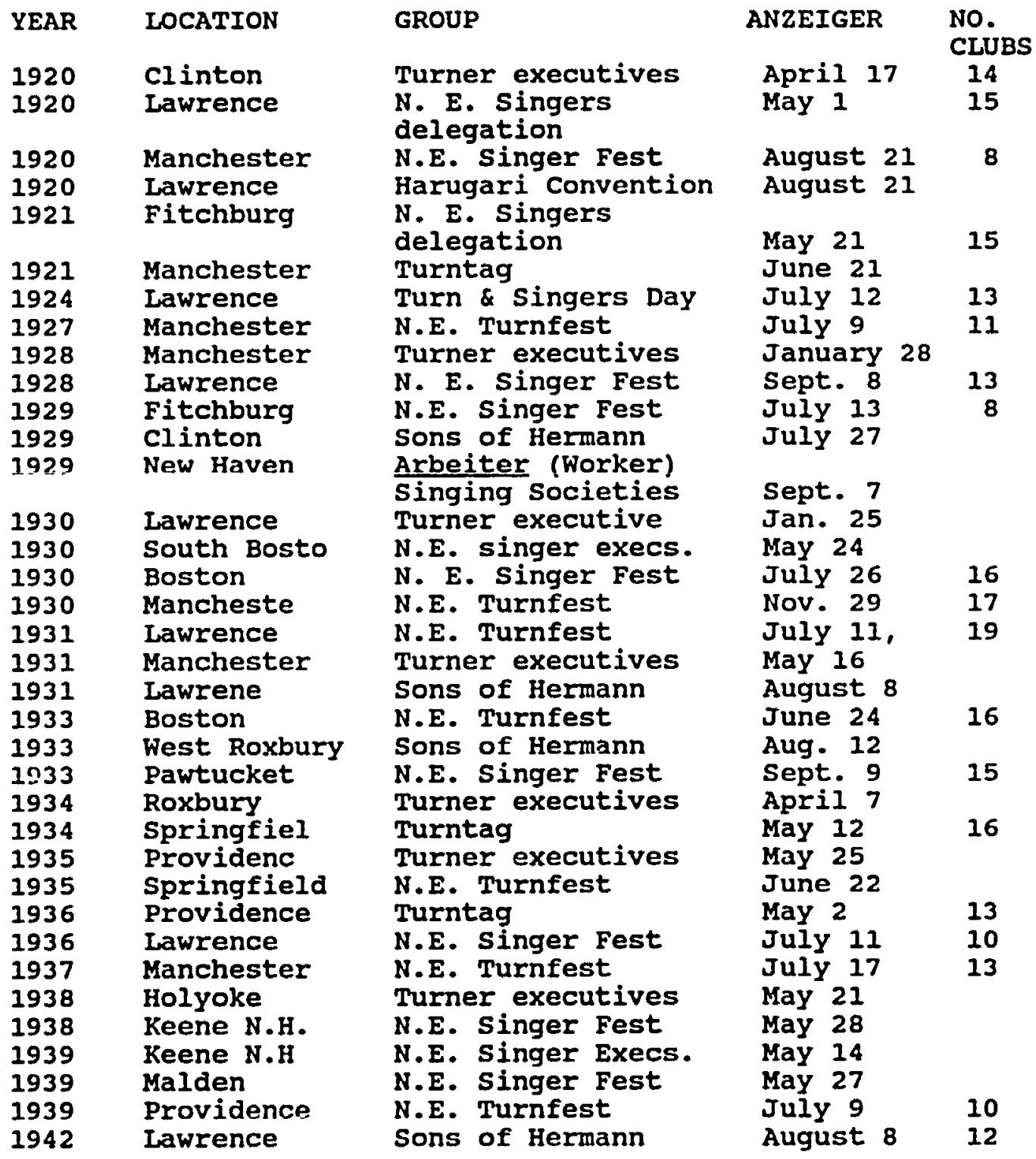


Keene, New Hampshire is beyond the scope of this investigation, but the discovery of an apparently strong German community there is un-expected. There was apparently a Mannerchor Lokal at 77 Elm street in Keene, Anzeiger und Post, May 14, 1939.

${ }^{18}$ Tracking the clubs is not always an easy task. For some years the city Directories list all clubs including their benefit and women's sub-sections for others only the main headings. Starting about 1935 the listings are much abbreviated. Another source is the contribution lists to the German School or Freebed committees, but all clubs do not always contribute. The 1920 Lawrence Directory lists 47 clubs including sub sections, of these about 25 are the main clubs. Lawrence Directory, 1920, 1925, 1930, 1935, 1940. Anzeiger und Post, February 2, 1935. Weekly events, September 12, 1936 and June 18, 1942. Similar activities May 16, 1936 and August 21, 1937.

${ }^{19}$ The Manchester Directory is not always an accurate listing since several clubs known to exist are not listed in 1930 and 1935. Also by 1935 all clubs have shortened listings. Manchester Directory, 1920, 1925, 1930, 1935, 1940. Anzeiger und Post, April 9, 1938 lists 8 clubs in the calendar: and February 1, 1936 lists seven contributing to the German school; in 18 June 1942, it lists 11 clubs.

${ }^{20}$ Anzeiger und Post. May 11, 1935, appointment of Gerhardt Haase. Anzeiger und Post, September 12, 1933. appointment of A.G.R. Sandmann, and interviews with Mrs. Sandmann. Manchester Turn Verein 100th Anniversary Souvenir Booklet, 1970. Metzner, History of Turners, 39-40. Sandmann continued as paid instructor for a number of years before he took a job at Hermsdorf Manufacturing Company, founded by Germans, and continued as a part-time volunteer instructor. In 1956 he won a National Honor Key from the American Turners. Anzeiger und Post, fire, flood, reopening, and Turnfest. February 1, 1936: February 27, 1937; July 17, 1937. Manchester Union Leader, Jisy 4, 1937, Turnfest. Anzeiger und Post February 19, 1928, March 17, 1928 and April 18, 1931. Iooth Anniversary Booklet, the Turnschwestern were credited for keeping the Turn Verein afloat with their masked balls and minstrel shows during Prohibition,

\section{Anzeiger und Post, August 14, 1920.}

22 Manchester Directory, 1930, 1935. Anzeiger und Post, June 13, 1936, Reinhard Hecker died at the age of 78 . Manchester Turn Verein 100th Anniversary booklet, J. Adam Gebhart. Anzeiger und post, July 6, 1935, Gustav Boettcher died at the age of 74. Anzeiger und Post, July 11, 1931 and 100th Anniversary Book, Erwin Boettcher Sr. (b. ca 1896) and Erwin, Jr (b. ca. 1920). 
${ }^{23}$ Anzeiger und Post, November 30, 1929, he died at the age of 71. Manchester Directory, 1925.

24 Interview with Dorothy Emmert and Jay Emmert. Lawrence Directory, 1910, 1915, 1920, 1925, 1930. Deutsches Ereibett Kommitee, Protokol Bücher, 1892-1941.

${ }^{25}$ Lawrence Directory, 1910, 1915, 1920, 1925, 1930, 1935. Anzeiger und Post, May 19, 1928, December 7, 1929, July 2,1928 . November 10, 1928. November 1, 1930. May 23, 1931. February 17, 1934, September 24, 1932, 50th Wedding of the Martins, December 11, 1937.

26 Lawrence Directory, 1930. Plus interconnectedness was further illustrated by the delegates elected from each Verein to the city wide organizations such as the Free Bed Committee, General Relief Society or German school. Thus, a few dedicated individuals could be in several leadership positions.

27 Anzeiger und Post, May 28, 1921. April 17, 1926. July 26, 1926, November 19, 1927, June 26, 1926.

28 Anzeiger und Post, Bertha stroebel of Lawrence, July 14, 1923. Catherine Leinsing, Manchester, November 23, 1923. Selma Langer, "Loyal german Hausfrau," July 7, 1928. Mary Roth, was buried from $s t$. Lawrence (Catholic) Church, but not the German parish. She is another example of a Catholic beionging to the Turnverein, June i8, 1932. Agnes Koehler, June 25,1932 . The obituaries on women give less information than profided for men. Up until about the 1920's they did not even give the first name of the woman, but listed them as Frau (husband's last name).

${ }^{29}$ Interview with Herbert and Helen Paul. Sponsored by an aunt, he immigrated to Manchester in 1927. She immigrated to New York in 1928. They met on the boat on a return visit to Germany and were married in 1932 in Manchester. Wedding report Anzeiger und Post, April 16, 1932.

${ }^{30}$ Interview with Madge Sandmann. Anzeiger und Post, July 11, 1931, JuIy 17, 1937, and May 11, 1935.

${ }^{31}$ Gordon, Assimilation in American Life, pp. 35-38.

32Maxine Seller, To Seek America: A History of Ethnic Iife in the United States, (New York: Jerome S. ozer, 1977), pp. 156-161.

${ }^{33} \mathrm{Niebuhr}$, Denominationalism, pp. 211-213.

${ }^{34}$ Obituaries from the available issues of the Anzeiger und Post from 1920 to 1942 were examined. The information is 
often incomplete. For instance an obituary did not always include information about a church service. Therefore, the information is not completely reliable, but probably gives a good indication of congregation size. Numbers are for both cities.

$\begin{array}{lr}\text { Unclear or no information } & 402 \\ \text { German Presbyterian } & 138 \\ \text { Catholic } & 46 \\ \text { Non sectarian/free thinker } & 25 \\ \text { Other/Aiterican congregations } & 22 \\ \text { German Methodist } & 21 \\ \text { Lutheran } & 18 \\ \text { Evangelical \& Germ. New. Ch. } & 15 \\ \text { TOTAL } & 687\end{array}$

The Presbyterians are $20 \%$ of the total. They are $48 \%$ of the total (285) for listings including a denomination plus the free thinkers. The actual size is between the two percentages, probably $35 \%$ which still made it the largest single German denomination.

${ }^{35}$ See above. Anzeiger und Post, September 20, 1920, December 5, 1921. For contributions to the German School see February 4, 1933 and February 2, 1935 when the fee was $\$ 50$; and February 6, 1937 when the fee was $\$ 40$.

36 Manchester, First German Presbyterian Record Book.

37 Manchester, NH, Marriage Records. Anna Melhorn sister of Lydia married in the German Lutheran church. First German Presbyterian Church, Manchester, Church Register 1882-1930. Individuals were admitted to the church as follows: Lydia Melhorn, 1899; Martha Babel 1899, and Ida Rosler in 1903. Interview with Herbert and Helen Paul; marriage announcement in Anzeiger und post, April 16, 1932.

${ }^{38}$ Manchester, First German Presbyterian Church Record Book, 100th Anniversary Book, Anzeiger und Post, Pastor Kamm's birthday March 22, 1930, 25th anniversary of service June 6, 1931 and death notice March 30, 1935 also Manchester Union, March 22, and 29, 1935. Pastor Kamm was 65 at the time of his death. Lawrence German Presbyterian church, 50th, 75th, and 100th Anniversary Books, Anzeiger und Post, 25th anniversary of service June 6,1931 , retirement 28 January 1939, and death notice September, 12, 1942. F.M. Veitor birthday, April 18, 1925.

${ }^{39}$ Manchester, First German Presbyterian Church Minutes of the Session.

40 Manchester, First German Presbyterian Church, Protokol Buch des Jugend Vereins. 
41. Articles cited from the Anzeiger und Post: January 19, 1920, Die wichtigkeit der deutschen Sprache July 4, 1931, Unsere deutsche Sprache

August 221931 Vergesst die deutsche Sprache nicht! R. Buhmer August 29, 1931, Die deutsche Sprache

May 5, 1934, Das Deutschtum und die deutsche sprache, willy KnUpfel

April 25, 1936, The German Language in America, Concord Society

March 8, 1930. Deutsch oder English in deutschen Verein?

September 8, 1937, Spricht deutsch zu Hause

Other articles appeared,

July 11, 1927 Die Wert der deutschen Sprache

July 191928 Von Wert der deutschen Sprache

August 31, 1930 The Concord Society

September 30, 1930 Deutsch-Amerikanischer Kulturasustausch

June 23, 1932, Zuknfunt der deutsche Presse in U.S.

August 20, 1932, Die deutsche Sprache

June 16, 1934, Warum deutsche Sprache?

June 7, 1936 Die deutsche Sprache

April 16, 1938, Die deutsche Sprache

June 15, 1939 Die deutsche Zeitung

42 The organizational siructure of the schools appeared once or twice each year. For an example see, Anzeiger und Post, February 6, 1937. Delegates from 28 clubs were elected and each club made contributions. The German Presbyterian Church had the highest amount at $\$ 50$; next was the Hermanns Hall at $\$ 30$; the Bavarian $R$. \& $P$. club, the Turnverein, and the central club each gave $\$ 25$; the lowest amount, $\$ 5$, was given by five clubs mostly singing societies and the women's branches of the major clubs. Similar reports appear January 3, 1931, February 6, 1932, February 4, 1933, 1933 fee was $\$ 50$ and February 2, 1935 and incorporate note from school list.

43 Anzeiger und Post, July 7, 1917.

${ }^{44}$ Manchester Union, July 3, 1917. School figures from Anzeiger und Post, August 1, 1914, January 29 and February 6 1916, January 27, 1917, February 2, 1918, February 5, 1921, February 6, 1926, January 27, 1927, February 2, 1929, October 11 1930, February 1 and 6, 1932, February 4, 1933, January 5, 1935, February 1, 1936, February 6, 1937.

${ }^{45}$ Harold G. Dick with Douglas H. Robinson, The Golden Age of the Great Passenger Airships: Graf Zeppelin and Hindenburg, (Washington D.C.: Smithsonian Institution Press, 1985), p. 23. "Dick Family Genealogy," (ICA 90.79.01).

${ }^{46}$ Dick and Robinson, Passenger Airships, pp. 20-22. 
${ }^{47}$ Ibid., p. 43. Lawrence Directory, 1920, the language teacher was Elizabeth O'Leary.

${ }^{48}$ Gordon, Assimilation, pp. 124-5, 148-9, 205-6.

${ }^{49}$ There is no information as to whether o'Leary the daughter of a German and an Irishman. She lived on Jackson street which just boardered the German district.

50 Manchester, NH, Marriage Record Books.

51 Mariahimmel fahrt (Assumption B.V.M.) Marriage Record Book, 1917-1940. Access to marriage license records in Lawrence is more restricted, but the data is considered to be similar to Manchester and to the Catholic records.

${ }^{52}$ Ruby Jo Reeves Kennedy, "Single or Triple Meltingpot?" Intermarriage in New Haven, 1870-1950." American Journal of Sociology, 58 (July, 1952): 56-59.

53 Manchester, NH Marriage Record Books, 1875 to April, 1936, Volumes 4 to 17 .

${ }^{54}$ Manchester, NH Marriage Record Books.

55 Manchester NH, Marriage Records. First German Presbyterian Church, (Manchester), Records and Minutes.

${ }^{56}$ Interview with Dorothy Emmert and Jay Emmert.

57 Mariahimmlefahrt, Marriage Record Book, In 1991 the president of the the Concordia Social club was Barry Daley, whose great-grandfather was one of the founders of the concordia Schutzen club. He lived in his grandfather's house which was adjacent to the club. Letter from Barry Daley to author June 26, 1991.

${ }^{58}$ Anzeiger und Post, July 11, September 1, 1923.

${ }^{59}$ Not to be confused with the Carl schurz vereinigung created in Germany to foster friendship beiween Germany and the U.S. and which later came undeer Nazi influence. See Rennie W. Brantz, "German-American Friendship: The Carl Schurz Vereiniqung, 1926-1942," The International History Review, 11 (May, 1989) : 229-251. The Lawrence unit was Karl Schurz unit no 369 der steuben Society von Amerika.

${ }^{60}$ Frederick C. Luebke, "German-American Leadership strategies Between the World Wars." in Germans in the New World: Essays in the History of Immiaration, ed. Frederick c. Luebke, (Urbana, University of Illinois Press, 1990), pp. 58-74. 
${ }^{61}$ Anzeiger und Post, December 3. 1927.

${ }^{62}$ Anzeiger und post, september 27, 1930. The reporter summarized the speech which he noted was rather long.

${ }^{63}$ Anzeiger und Post, December 10, 1938.

${ }^{64}$ Anzeiger und post, october 10, 1937.

${ }^{65}$ Anzeiger und post, September 4, 1937, May 14, 1938.

${ }^{66}$ Anzeiger und Post, October 8, 1938 .

${ }^{67}$ Anzeiger und post, June 25, 1938.

${ }^{68}$ Anzeiger und Post, June 25, 1938 .

69 Anzeiger und Post, June 25, 1938.

70 on the Versailles Treaty see Lloyd E. Ambrosius "Ethnic Politics and German-American Relations after World War I: The fight over the Versailles Treaty," in Germany and America, ed Trafousse, 29-40

$71_{\text {David }} \mathrm{H}$. Bennett, Demagogues in the Depression: American Radicals and the Union Party, 1932-36, (New Brunswick, Rutgers University Press), pp. 111-115, 4, 281. Alan Brinkley, Voices of Protest: Huey Long, Father Coughl in and the Depression, (New York, Alfred A. Knopf), 1982 . Arthur M. Schlesinger, Jr. The Politics of Upheaval, (Boston, Houghton Mifflin Co, 1960), pp. 73, 79-81, 85 . Geoffrey S. Smith, To Save a Nation: American Countersubersives, the New Deal, and the Coming of World war II, (New York, Basic Books Inc, 1973), pp. 58-59, 64-67, 71$73,142-43$.

72 Tischauser, Burden of Ethnicity, p. 171. F. Luebke, Germans in the New World, pp. 68-72.

${ }^{73}$ Konrad Jarausch "Perceptions," Wilson Quarterly, (Summer 1981): 62. One of the more famous admirers of Hitler was Charles Lindbergh. G. Smith, To Save a Nation, p. 93.

${ }^{74}$ Tischauser, Burden of Ethnicity, 204.

75 wittke, German Language Press, 284.

76 "The Foreign-Language Press," Fortune, 22 (November, 1940), 93. For more on the efforts of the editors of the New York Staats-Zeitung to avoid Nazi Pressure see, Stephen Economides, Der nationalsozialismus und die deutschsprachige Presse in Newe York, 1933-1941. Frankfurt: Peter Lang, 
1982. See also Bayor, Neighbors in Conflict, pp. 65-69, 73$76,115-117$.

77"Foreign Language Press," Eortune, 92-93.

${ }^{78}$ During this period a considerable number of issues of the paper are missing. The last issue at the Peabody Essex Museum is october 28, 1933. The peutsche Auslandinstitut, in Stuttgart, apparently had a subscription that began in January 1934, and appears to have ended or war conditions made it difficult to get the paper after 1939. There are a number of missing issues in addition to the following gaps: January through March, 1938; June through September 1938; and January through July, 1939. Their last issue is November 25, 1939.

79 Anzeiger und Post, December, 19, 1931.

80 Anzeiger und Post, March 25 and April 1, 1933.

${ }^{81}$ Anzeiger und Post, March 18, 1933.

82 Anzeiger und Post, March 25, 1933.

${ }^{83}$ Anzeiger und Post, April 1, 1933.

${ }^{84}$ Anzeiger und Post, April 15, 1933, the article was by Karl Wehnert, who is not further identified.

${ }^{85}$ Anzeiger und Post, April 15, 1933.

${ }^{86}$ Anzeiger und post, July 21, 1934. Clara Duemling, born in Derry NH, Iived with her mother in West Andover, MA was a 22 year old student at Boston University who spent a year in Germany on a stipend from the German club of the University. Her letter to her mother, was printed by the Anzeiger und Post and the Lawrence Evening Tribune (July 14, 1934), which included her picture.

${ }^{87}$ Anzeiger und Post, October 7, 1933, the article was taken from a speech at a "German Day" in Newark, N.J. by John Koerber, who is not further identified.

${ }^{88}$ Anzeiger und Post, October 7, 1937, William Seabrook, "America über Alles," The American Magazine, (October, 1937), 82-93. Seabrook claimed to be partially of German descent. He led a rather adventuresome life, and wrote several books about his times in Africa and elsewhere. He also wrote for The American Magazine and several others. He was reasonably well known in 1930 s and early 1940 s.

${ }^{89}$ Seabrook, "America über Alles," 93. 
90 Anzeiger und Post, June 25, 1936.

91 Sander A. Diamond, The Nazi Movement in the United States, 1924-1941, (Ithaca, Cornell University Press, 1974) and Susan Canedy, America's Nazis, A Democratic Dilemma: A History of the German American Bund, (Menlo Park, CA., Markgraff Publications Group, 1990). A criticism of Diamond's interpretation of the role of the Deutsche Auslandinstitut, (DAI) in stuttgart, can be found in Heinz Kloss, "Sander A. Diamond's Surrealistic Portrait of Research Done in the Third Reich on German Americans, trans. La Vern Rippley, Journal of German American Studies, 12 (1977), 4972. Kloss' argument is that only the records of the DAI survived the war, and that other organizations were much more involved with the Nazis. Another work on the DAI and the Nazi organizations is Arthur L. Smith, Jr. The Deutschtum of Nazi Germany and the United States, (The Hague, Martinus Nijhoff, 1965).

92 Both Diamond, Nazi Movement, p. 8, and Canedy, America's Nazi's, p. 32 say that there were 430,000 immigrants from Germany between 1919 and 1932, which is taken from the statistical History of the U.S., pp. 56-7. Diamond, Nazi Movement, 147 concludes that the most of the members were probably catholics from Baden, Bavaria, and württemberg.

${ }^{93}$ Diamond concludes that the Bund was a small organization which promoted itself and received much more attention than its size deserves. Dieckhoff is quoted by Diamond, Nazi Movement, p. 289 (source Documents on German Foreign policy, D, I, 671).

${ }^{94}$ Canedy, Americas Nazis, p. 22.

95 Diamond, Nazi Movement Appendix II, p. 358. This was based on charts of the German-American Bund, from the "Hearings, Part IV, Appendix, 1503-04." Curiously it includes 47 states and the District of Columbia. Missing is Texas, which actually had a much larger German population than Vermont, Maine, or New Hampshire. The Bund list nrnhahly proudly included all 48 státes.

${ }^{96}$ Canedy, America's Nazis, 83.

97 The Commonwealth of Massachusetts, Report of the Special Commission to Investigate Activities Within this Commonwealth of Communistic, Fascist, Nazi, and other Subversive organizations, So Called, Boston, 1938. Only 5 pages of the 599 page report were devoted to Nazis.

${ }^{98}$ commission, p. $19.2021,22,23$. 
${ }^{99}$ Luedecke was a Nazi party member who left Germany to attempt raise funds in the the United for the Nazis. For more information see: Diamond, Nazi Movement, pp. 75, 97 ; Smith, Jr. Deutschtum, pp. 65-66, 68-68, 77, 79, 115; and G. Smith, To Save a Nation, 88 .

${ }^{100}$ Commission, pp. 20-23.

${ }^{101}$ Diamond, Nazi Movement, p. 248.

102 Commission, pp. 20-23.

${ }^{103}$ Ibid., p. 20.

${ }^{104}$ Lawrence Directory, 1935.

${ }^{105}$ Commission, 23.

106 Lawrence Directory, 1925. The three synagogues list among its officers such names as Baker, Zack, Weiner, Goldberg. Dora Franklin, comp "History of the Jews of Lawrence," (ICA 75.12.1) mentions among the early Jews, Cohens, Goldsteins, Richsteins, Traubs, Bermans, Hershoffs, Goldbergs, Kaufmans, Bergers, etc. In Manchester, the information was taken from the Manchester Marriage Records, most names were Russian.

107 Anzeiger und Post, May 16, 1903.

${ }^{108}$ Anzeiger und Post, September 23, 1911.

${ }^{109}$ Anzeiger und Post, January 25, 1919.

${ }^{110}$ Lawrence Directory, 1940, among the officers of the Y.M.H.A were Aaron Bernson and Moris Kaplan, and of the Y.W.H.A. Lina Tepper, Mae orenstein, and Mary Richstein. Also the Lawrence Chapter Senior Hadassah, loth Year Book, 1940 (ICA 92.120 .05 ) includes names such as Feldman, Fineberg, Glazerman, Goldstein, Holt, Katz, Niestadt, Rosenberg, Schwartz, Sigliman, Weirnick, Weissbein, Weiner, and Weinstein.

${ }^{111}$ Fourth Annual Black and White Review, December 4, 1935, (ICA 78.18.15) Lawrence Tribune, December 29, 1980 obituary of Izzy Goldberg: The Racket store was started by his Grandfather Benjamin Goldberg in 1898. Izzy was born in Lawrence, and was veteran of Army Air Force in World War II.

112"The Lacht Nacht," (ICA 78.18.21) November 9, 1936, program booklet. Also Senior Hadassah. 1936 (ICA 92.120.03) and Senior Hadassah, 1939, (ICA 92.120.04). 
113 Julius Stern, "From Herzenbock in Germany to Andover, Massachusetts, U.S.A., Autobiography of Julius stern of Marum Knitting Mills Mass." Typewritten at Immigrant City Archives, (ICA 86.17.1), 1-51. The mills in Germany were named Marum also. His wife's uncle was a Richard Loeb of New York. There is apparently no connection with William Loeb of the Manchester Union Leader.

114 Ibid., p. 52.

${ }^{115}$ Ibid., pp. 52-54

116 Ibid., pp. 61-62.

117 Ibid., pp. 64.

${ }^{118}$ A. Smith, Jr., Deutschtum of Nazi Germany and the US, p. 43. This was in a report to the Deutsches AuslandIstitute, stuttgart. It was undated but was written during the 1930s (source German Records, 5079911-5079917). 


\section{END OF DEUTSCHTUM}

World War II ended Deutschtum in Manchester and Lawrence. But the end was not explosive. There were no riots, no anti-German hysteria, nor belligerent counter attacks. Rather, Deutschtum quietly evaporated in the face of events. To be sure, certain aspects of German-American life continued after the war, but 1942 marks the end of the Deutschtum as it had existed in those cities.

The outbreak of War in 1939 came as a shock to the editors of the Anzeiger und Post. It was unthinkable that another war should occur so soon. The paper said that this was a real "come-uppance" for the German-American.1 The paper was clearly concerned with the position of the GermanAmericans and the reaction of the larger community. It stated that there was no longer an "argument that GermanAmericans vere patriotic citizens." 2 Furthermore, "the war is not our war." ${ }^{3}$ The paper wanted the United states to stay out of the war. However, remembering World War I, it wondered if neutrality could be maintained through laws, as the Roosevelt Administration intended. It also desired no return to the munitions trading of the previous war. Could we not offer the end of trade in munitions on the "alter of peace?" 4 the paper asked. 
No surviving issues of the Anzeiger und Post have been found from October, 1939 to June, 1942. Therefore, neither the attitudes of the paper toward the issues of the war nor the activities of the Vereinsleben can be followed through this crucial period. The next available paper for review is June, 18, 1942. By then the United States had been at war with the Axis Powers for six months. At that time, the newspaper clearly made an attempt to prove that it was American. In one issue, its front page contained a boxed statement (in German) explaining that it was

an American newspaper appearing in the German language, as a connecting link to German-Americans, and for the maintenance and support of German culture and tradition.5

Page four contained a boxed statement (in English) informing the readers that it was a

member of the New England Foreign Language Newspapers Association. Our policy: 'The purpose of the Association shall be to help preserve the ideals and traditions of our country, the United States of America, revere its laws and inspire others to respect and obey thom, and in all ways to aid in making this country greater and better. 16

The same page also contained a box with the American flag and the statement, again in English, "make every payday bond day." 7 The paper clearly tried to present itself as a patriotic American newspaper. As a Gezman-language newspaper it certainly must have felt the important need to do so. It also must have been aware that questions were being raised in the American press, as evidenced by the Fortune article in 1940, about the loyalty of the foreign-language press. 8 
In almost every other respect it was the same newspaper. It had representatives in Taunton, Fitchburg, and clinton, Massachusetts; Manchester and Keene, New Hampshire; and Providence and Pawtucket, Rhode Island. It was also seeking to find representatives for Holyoke, Adams, and Springfield, Massachusetts, and to expand its coverage by finding representatives in Hartford and New Haven, Connecticut. It contained eight pages as it had since 1896.9

For a time, the paper once again appeared to have a split personality. Its front page contained news from around the world including a statement by "Propaganda Minister Goebbels" who was unconcerned with "Churchill's threat of war on two fronts."10 Its war reports included communiques from German military sources about Germany's armies in Russiall. It also reported that the United states had interred 8,500 enemy aliens, which was "less than one percent of the total enemy aliens in the country $(1,100,000), "$ and of the number "556 were German."12 It included a war Production Board report regarding the "war on the home front."13 In its August 1 issue it contained a report from the German High Command with communiques about troops on the Russian front and in the Afrika Korps. The same issue contained an insert for war Bonds, printed in German, and proudly noted that German-American generals Eisenhower and Spaatz lead the American army and air forces. 14 A few weeks later it pointed out that the grandfather of Admiral Chester Nimitz had emigrated from Germany, but the same issue also contained a 
communique from the German High Command. 15 Soon, the Manchester representative reported the names of club members serving in the American military. 16 As 1942 wore on, the communiques from the German High command receded and the news became much more in tune with the objectives of the American government.

A careful reader of the news reports in the paper during this time could uncover disturbing news about Germany. The paper reprinted an article from the office of War Information about the landing of saboteurs from a German submarine, and who were quickly arrested. The paper castigated the Nazi bosses who thought that German-Americans would support the saboteurs. The paper reiterated the loyalty of German Americans. 17 The same issue carricd a report that Germany was to be without Jews by the end of August. It reported that all Jews in Germany were being transported to Poland in cattlecars. 18 presented without comment this should have been revealing information for many readers. Later, the paper informed its readers that over 1,200 Norwegian patriots had been arrested by the Nazis and the Quisling government. 19 The paper reported these news items without comment, perhaps because it was embarrassed by them. Nevertheless, they showed the old homeland in a bad light.

The paper also attempted to set the record straight regarding the loyalty of German-Americans and distanced German-Americans and German culture from Hitler. Its attitudes about Hitler and Nazism were clear when it stated 
that:

They were not spies, saboteurs, or traitors. The overwhelming majority of German-Americans were enemies of Nazism and Fascism. Those who supported the old homeland or neutrality or isolationism were forgetting

how the culture of the old homeland had been taken over by Nazi barbarism. Only when this world enemy is defeated and the German people regain their freedom will it be possible to raise up German culture.

....[W]e have not yet lived through a "war hysteria [as in 1917-1918]. We must openly demonstrate our true feelings and help for our land.... We also know that Germany is not Hitler. Many thousand German-American sons are in the uniform of our country and at the front against Nazism and Fascism... and many thousand more will follow.

...there should be a conference of German-Americana, with delegates from the Vereine...so that the people and government will know of the trust and loyalty of the German-American. 28

Apparently little came of the call for a conference. In World War II German-Americans were not subjected to the hate and hysteria of World War $I$, and little real doubt as to their loyalty existed. Most likely, the call of the paper put into words the private feelings of most of its readers. Apparently, both a decline in the number of readers of the paper and the overwhelming situation of the war spelled its end. According to Arndt, cataloguer of the GermanAmerican Press, the paper was "suspended, at least for the duration of the war in 1943."21 The last surviving issue is October 24, 1942. By this time the descendants of the original publishers were not involved full-time with the paper. William Dick lived in Boxford, Massachusetts, a rural town about fifteen miles from Lawrence. Carl Trumpold 
worked in the Press Room of the Lawrence Eagle Tribune, returning to where his father started, while Frederick Trumpold worked as a printer for the Anzeiger und post. 22 During this time, Kurt schindler edited the newspaper, rather than one of the co-owners. 23 The paper probably failed for several reasons. One reason may have been the reduced attention given to the paper by the principals. Another is that the paper was losing direction and meaning and had been for some time. Another was that there were fewer German readers in the cities, and those remaining were less interested in reading the paper. It finally just gave up. However, the end of the Anzeiger und Post marked the passing of Deutschtum in a dramatic way. Without the paper the German churches and clubs lost one of their most important supports.

Moreover, by this time the churches also quietly distanced themselves from their German heritage. In 1942, the elders of Manchester's First German Presbyterian Church voted to become the First Presbyterian Church and to end services in the German language. 24 In January 1943, the Lawrence German Presbyterian Church became the Christ Presbyterian Church. 25 During 1942, in Lawrence the German Methodist Church became the vine Street Methodist Church, 26 and in Manchester the First German New Church quietly became the Church of the New Jerusalem. 27 Also in Manchester, The German Lutheran Emanuel Church quietly called itself The Evangelical Lutheran Immanuel Church. 28 German churches, 
among the last bastions for preserving German religion, culture, and language, had found it no longer a good idea to retain the designation "German," and they had quietly abandoned that part of their heritage.

In 1942, apparently, the local Vereinsleben continued as it had in 1939. In Manchester eleven different clubs or their sub-sections held regular meetings. The major clubs, including the Turn Verein, the Workingmen's Relief association, the Harugari and Sons of Hermann still existed. The Workingmen's Relief Association (A.K.U.V.) purchased a $\$ 1,000$ war bond. In Lawrence the social scene of the clubs was in full swing. The Harugari club held a dance and cabaret every Saturday and lobster dinners every Friday, Saturday and Sunday evenings; the Hermanns-Halle held a dance and entertainment every week; a floor skow, orchestra, and dance entertained guests every Saturday in the Turn-Halle; and the Bavarian Hall provided entertainment and dancing every Saturday. The Lawrence German School and Altenheim issued their regular reports of activities and financial standing. 29 In August, the general meeting of the Sons of Hermann of Massachusetts was held at the Lawrence Hall. Representing the men were lodges from Lawrence, Holyoke, Adams, Turner's Falls, Boston, Clinton, Fitchburg, Greenfield, New Bedford, Massachusetts, and Manchester, New Hampshire; and the women were represented by Lawrence, Holyoke, Fitchburg, Clinton, East Hampton, Boston, Springfield, Greenfield, West Roxbury, and Manchester. 
Joseph Ruess of Lawrence was elected overall president for the state organization. 30

The social activities kept the clubs alive while they slowly declined. The Lawrence Turnverein staged a welcome home party for its members in the service. ${ }^{31}$ In 1947 the "German American Singers of Lawrence" held a benefit concert for the relief of Germany. 32 In 1948, the national executive council of the American Turners met in Lawrence and roundly condemned communism at its final session. 33 In 1950 , the New England Turntag, held in Lawrence, still managed to attract teams from Adams, Boston, Clinton, Fitchburg, Springfield, Pawtucket and Providence, Hartford, and Manchester. 34 The Lawrence Turnverein attracted the New England Turnfest in 1964, and in 1965 it celebrated its one Hundredth Anniversary. Of eighteen members of its board of directors ten had German last names. Only a few years later, when its board of directors consisted of Ken Silverman, Lou Cote, Gary Santacrosse, Vin Marconi, Archi Santacrosse, and Rocky Zambino the club disbanded. 35 In Manchester, by 1951, only the Workingmen's Relief society, the Harugari club, and the Turn Verein remained. The president of the latter was oswald Loiselle. 36 Described as "one of the last German lodges still functioning in the city," the Martha Washington Lodge of the Sons of Hermann dissolved in 1973.37 In the meantime the Manchester Turn Verein celebrated its one Hundredth Anniversary in 1970. Of fourteen members of its board of directors eight had German last names. 38 In 1977, the Turn 
Verein dissolved and its building become a restaurant, 39 which later burned down. These societies had managed to hold on for a number of years after the war, but they had been weakened by the war. After World War II, immigrants from Germany did not come to the cities in sufficient numbers to keep alive or revitalize them. A few third-generation German-Americans who remained in the cities tenaciously kept them going. But their sons and daughters were moving away from the area, and they slowly declined and closed. They had also lost their particular German characteristic..and purpose and were primarily bowling or social clubs.

In both Manchester and Lawrence the German schools outlasted the war. Not surprisingly, as it appeared to have always been the lower attended school, the one in Manchester folded first. With the graduation class of 1948 , it ceased operations. 40 The school in Lawrence continued to operate through the 1960s. A reporter for the Eagle Tribune commented on how the school "remained despite the passing of the many German halls that once in large part supported it." 41 The reporter noted that the previous year a visitor to the school from Germany, "patted a little blond girl's head after her flawless recitation and said, 'your mother and father must be German.' 'No,' said the girl, 'I'm Irish. '"42 The school continued to operate for several more years with studerts of German and non-German anncestry, but finally closed.

The gradual closing of the German stores and business 
marked another aspect in the passing of Deutschtum. The west side of Manchester once had a number of German businesses and stores that gave the area a special feel. One such company was the schonland meat processing company. Founded by William F. Schonland, who was born in Lawrence, and whose father had been born in saxony and established a meat processing company in Iawrence. By 1955, Arthur and Charles, the third generation, operated the company. The next generation did not continue in the business, and it was sold to a larger company. ${ }^{43}$ The schoenland brand is still sold in New Hampshire. "Judi's" Bakery another long-standing German shop also went out of business. Gustave Adolph Kretschmar, who "learned the trade in his father's bake shop in Saxony" 44 settled in Manchester in 1890 and founded the bakery in 1896. Four-generations worked in the bakery before it finally shut down in 1972.45 In Lawrence similar events occurred. In 1952 the cold spring Brewing company closed, being unable to keep up with the larger competitors and the loss of brewing talent. Boehm's cafe and other businesses closed one by one. As the textile cities slowly declined and larger chains began to dominate, the small family businesses were less able to compete. 46

The old neighborhood and the stores were gone and missed by many residents. Paul simon, who had owned a variety store across the street from the Manchester Turn Verein, recalled in 1983 that what he missed the most "was the old German community which was a part of me for so many years." 47 other 
residents remembered the neighborhoods fondly noting that they had a certain "feel" to them. 48

Sons returning from the war and able to obtain college educations on the G.I. bill saw little reason to remain in the cities. 49 They were less likely to return to the family iusiness and the old neighborhood. Furthermore, the home loan provisions of the G.I. Bill coupled with the Federal Housing Administration led to a boom of home ownership and suburbanization. 50 on the local level this resulted in migration out of Manchester and Lawrence, and in particular the predominately German Wards. The information is shown in Table 9.1. 
TABLE 9.1

POPULATION SHIFTS $1920-1960^{51}$

\begin{tabular}{|c|c|c|c|c|c|}
\hline & 1920 & 1930 & 1940 & 1950 & 1960 \\
\hline LAWRENCE & 94,270 & 85,068 & 84,363 & 80,536 & 70,933 \\
\hline WARD 2* & 16,621 & 15,025 & 14,333 & 13,737 & n.r. \\
\hline ANDOVER & 8,268 & 9,969 & 11,122 & 12,437 & 15,878 \\
\hline METHUEN & 15,189 & 21,069 & 21,880 & 24,477 & 28,114 \\
\hline MANCHESTER & 78,334 & 76,834 & 77,688 & 82,732 & 88,282 \\
\hline WARD $11 * \star$ & 5,453 & 4,825 & 4,701 & 4,578 & n.r. \\
\hline BEDFORD & 1,118 & 1,326 & 1,561 & 2,176 & 3,636 \\
\hline $\begin{array}{r}\text { GOFFSTOWN } \\
\text { (town) } \\
\text { (unic) }\end{array}$ & 2,391 & 3,839 & 4,247 & $\begin{array}{l}5,638 \\
1,336\end{array}$ & $\begin{array}{l}7,230 \\
1,052\end{array}$ \\
\hline
\end{tabular}

* Predominately German Ward

* Predominantly German Ward created in redistrictring in 1915.

n.r. not reported.

Sources: U.S. Bureau of the Census, Population, for

Fourteenth, Fifteenth, Sixteenth, Seventeenth, and Eighteenth Censuses.

Between 1920 and 1960 the population of Lawrence declined considerably. Not only did the population decline in the entire city, but in the German ward as well, while the neighboring towns of Andover and Methuen grew. The picture is a little less clear in Manchester. The city's population declined from 1920 to 1940 and then grew from 1950 to 1960. The compact center of Manchester centered around the Amoskeag, and available land for houses existed outside the core. In essence a suburbanization of the city occurred. 
Even though Manchester grew, its growth was lower than most other New Hampshire cities during this period. 52

Furthermore, the population of the predominantly German ward declined continuously from 1920 to 1950. In addition, during this period, the neighboring towns of Bedford and Goffstown grew, and at a much faster rate than Manchester. Also, a number of persons migrated out of the New England Region. 53

peutschtum in the vibrant sense that it was known to many first- and second-generation German-Americans prior to World War $I$ and even to some third-generation GermanAmericans between the wars had really ended by 1942, when the U.S. was once again at war with Germany. That year, the German-language newspaper, the promoter of Deutschtum and the Vereine and in turn supported by them, finally ceased publication. In 1942 the German churches decided to drop the ethnic identifier from their names. Although some of the clubs remained, they had lost their German meaning and character. They had been overtaken by the process of assimilation.

\section{Epilogue}

A few of the clubs remain in existence today as nonGerman social clubs. In Lawrence both the Bavarian Club and the Concordia social club continue to occupy their original buildings. Tney are now purely social clubs. The Dewey Social club, which had German antecedents as the pleasant Valley Citizens club, continues in Methuen. In Manchester 
the Workingmen's club exists purely as a social club. The unused ballroom still has an alpine scene on the large backdrop behind the stage. The Harugari Hall in Lawrence still exists but is now a production facility in which salads are packaged in plastic containers. The German school building in Lawrence, converted to apartments, recently suffered heavy damage by fire. 54 The Beethoven Munnerchor hall is now the rectory of the sacred Heart church in Manchester. The German school building in Manchester, first sold st. Raphael's parish, resold and long derelict, has been converted into law offices. 55 Lawrence's Deutsches Altenheim continues in opertion as the German Home, Inc., but currently the residents of the home are no longer German but of other nationalities.56 st. Raphael's continues as an active parish with Benedictine priests from St. Anselm's College. In Iawrence, the wooden, southern German style church building of Mariahimmelfahrt still stands. Now known by its English title, Assumption of the Blessed Virgin Mary, it is the mission church to the Hispanic Community of Lawrence, whereas it had once been the mission church to the Germans. Where German was once used in services, spanish is now used. The First Presbyterian Church building still exists in Manchester and it has an active congregation, including a few thirdgeneration German-Americans. The United Presbyterian Church occupies the building of the German Presbyterian Church in Lawrence. It recently merged with another Presbyterian church and has an active congregation, including some German- 
Americans.

These are the only reminders of a once vital and vibrant ethnic community that has totally disappeared. Those buildings that remain are but mute remainders of the hard work of the German immigrants in building them and the musical, theatrical, cultural and social events that happened in them. Recent Hispanic immigrants are adding yet another culture to Lawrence, the Immigrant city, and theirs is now now the only ethnic culture in the city. At one time Lawrence bosted a multi-ethnic culture, vibrant with the sights and sounds of many immigrant groups. Even in Manchester, around the turn of the century, Greeks and Poles added their culture to the Irish, Franco-American, and German cultures extant in the city. Now all are gone. The passing of these ethnic cultures has taken a vibrance and life out of the cities. Their passing attests to the homogenization of the American culture. 
CHAPTER NOTES

CHAPTER IX

${ }^{1}$ Anzeiger und Post, september 9, 1939. The article was signed by a Friedrich Kreutzer, who was not otherwise identified.

${ }^{2}$ Anzeiger und Post, September 9, 1939.

${ }^{3}$ Anzeiger und post, September 9, 1939.

${ }^{4}$ Anzeiger und Post, september 30, 1939.

5 Anzeiger und Post, June 18, 1942.

6 Anzeiger und Post, June 18, 1942.

7 Anzeiger und Post, June 18, 1942.

8 "The Foreign Language Press," Fortune, 22 ( November, 1940), 90-104.

${ }^{9}$ Beginning with the first issue, october 3,1896 , most issues except its 50th. Anniversary issue, February 8, i9ū8, and issues around Christmas, which had more advertising and numerous stories related to Christmas, had eight pages.

10 Anzeiger und post, June 18, 1942.

${ }^{11}$ Anzeiger und post, July 25, 1942.

12 Anzeiger und Post, June 18, 1942.

${ }^{13}$ Anzeiger und post, June $18,1942$.

${ }^{14}$ Anzeiger und Post, August 1, 1942.

15 Anzeiger und Post, August 15, 1942.

16 Anzeiger und Post, September 19, October 3, 1942.

${ }^{17}$ Anzeiger und Post, August 1, 1942.

${ }^{18}$ Anzeiger und Post, August 1, 1942.

${ }^{19}$ Anzeiger und post, October, 10, 1942. 
${ }^{20}$ Anzeiger und Post, October 10, 1942. Ironicly this was issue number one of the 60th year of the newspaper.

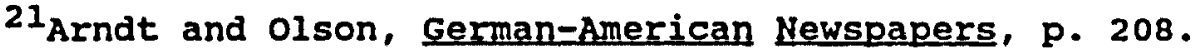

Last issue available, October $24,1942$.

22 Lawrence Directory, 1940, 1942, 1943.

${ }^{23}$ Arndt and 01son, German-American Newspapers, p. 208. Lawrence Directory, 1940 and 1942. No information about Kurt Schindler has been uncovered.

${ }^{24}$ First German Presbyterian Church, Manchester, Minutes of Session, 1939-1947. August 23, 1942 .

${ }^{25}$ Christ Presbyterian Church, Lawrence, 100th Anniversiary Bonklet, 1976. The pastor of the church was Hans Sidon, born in Germany, who served from 1939 to 1969. Hans Sidon, I Chose America: The Story of an Immigrant Pastor, (New York, Vantage Press, 1978), pp. 4, 45-46.

${ }^{26}$ Anzeiger und post, August 8, 1942.

27 Anzeiger und post, September 26, 1942.

${ }^{28}$ Anzeiger und Post, August 15, 1942.

${ }^{29}$ Anzeiger und Post. June 18, 1942. In Manchester the clubs holding meetings included the A.K.U.V. the Harugari club, the Barbarossa Lodge, the Barbara Lodge, The Manchester Turn Verein, The Turn Schwestern, The Schilier Lodge, The Martha Washington Lodge, The Turner Sick Fund, the NH Sick Fund, and the German school Verein.

${ }^{30}$ Anzeiger und Post August 15, 1942 contains information about the August 8,1942 meeting. Among those representing Manchester were Herbert Paul, who was interviewed for this paper, and Lena Schonland, of the sausage manufacturing family. Among those representing Lawrence were Julius Emmert, oswald Schmalfuss, and Martha Graichen, (both with families in Lawrence and Manchester), Wallista wiedner, and Katie Sontag. (ICA 85.86.2).

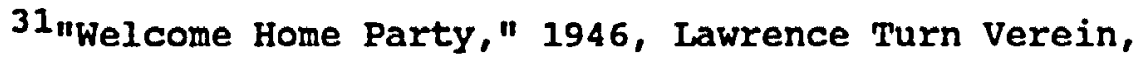

32"German singers Program" (ICA 79.136.1).

${ }^{33}$ Lawrence Evening Tribune, September 4, and 6, 1948 .

${ }^{34}$ Lawrence Evening Tribune April 1, 1950. 
${ }^{35}$ Lawrence Turnverein 100th Anniversary Booklet, on the board of directors were Fred Frisch, Joe Twomney, Ken Silverman, Al Pepin, Vin Connel, Chuck Bouchard, Harry Hall, Leo McDermott, Dick Weber, Ted Erler Henry Reinhold, William F. Reinhold, Jr, James Hoegen, Ernst Perrault, Kay Hoegen, Genie Witzgall, Ed Witzgall.

${ }^{36}$ New Hampshire Sunday News, October $28,1951$.

${ }^{37}$ New Hamsphire Sunday News, December 16, 1973.

${ }^{38}$ Manchester Turn Verein, 100th. Anniversary Booklet, President Ralph Rannacher, Vice President Jerry Healy, Treasurer Robert Riedel, Recording Secretary Charles Spaulding. Other officials included, Robert Lyscars, Don willkins, William Boetcher, Gerry Cote, Gerhard Hecker, Gerry Picard, Jerry Manning, Robert Trumble, "Pop" Boetcher, Andy Gianitsis.

${ }^{39}$ New Hampshire Sunday News, July 31, 1977. Interviews with Erwin Boetcher (April 18, 1986) and Madge Sandmann (March 12, 1986 and June 10, 1991).

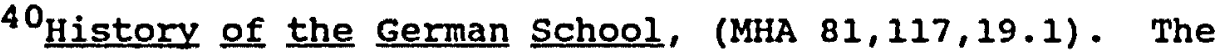
building was sold to st. Raphael's. A scholarship for studying German was established at the University of New Hampshire, and the remaining funds were distributed to the three German churches, the First Presbyterian, the New Jerusalem and Immanuel Lutheran.

${ }^{41}$ Andy Coburn, Lawrence Eaqle Tribune, October 5, 1966. 42 Ibid.

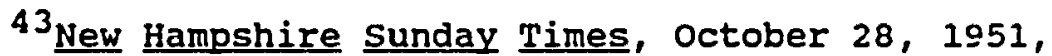
Manchester Union Leader, December 2, 1955, "Schoenland" section. william Schonland had received a patent on a sausage filling machine. Interview with Anna Schbnland Van Loan.

${ }^{44}$ George Naum and Madge Sandmann, Manchester Union, "Judi's Bakery Closes its Doors," January 3, 1972 .

45 Ibid.

46 Anderson, Beer New England, p. 175.

47 Manchester Union Leader, "Paul Simon Looking Ahead," July 2, 1983.

${ }^{48}$ Interviews with Madge Sandmann, Elsie $\mathrm{zindt,} \mathrm{Herbert}$ and Helen Paul, Anna Schonland Van Loan, and Dorothy Emmert. 
${ }^{49}$ Marc Miller, Irony of Victory, pp. 138-161.

${ }^{50}$ Kenneth T. Jackson, Crabgrass Frontier: The Suburbanization of the United States, (New York, Oxford University Press, 1985), pp. 204, 205-218, 233, 238-39

${ }^{51}$ U.S. Bureau of the Census population, Fourteenth Census, 1920, pp. 230-231, 255:: Fifteengh Census, 1930, pp. 499, 503, 507,704-705; Sixteenth Census, 1940 pp. 481-83, 660-662; Seventeenth Census, 1950, pp. 21-10, 21-13, 29-6; Eighteenth Census, 1960, pp. 481-483, 660-662.

$52^{\text {Growth }}$ of selected New Hampshire cities.

$\begin{array}{lcc} & 1940-50 & 1950-1960 \\ \text { Manchester } & 6.5 \% & 6.7 \% \\ \text { Nashua } & 5.3 \% & 12.8 \% \\ \text { Portsmouth } & 27.08 & 37.28 \\ \text { Rochester } & 14.1 \% & 15.6 \%\end{array}$

Source U.S. Bureau of the Census, Seventeenth Census, pp. 296; Eighteenth Census, pp. 8-11.

$53 \mathrm{~A}$ number of persons interviewed during this project mentioned that their children lived out of New England.

${ }^{54}$ Lawrence Eagle Tribune, August 24, 1992.

${ }^{55}$ New Hampshire Sunday News, May 24, 1970.

${ }^{56}$ Lettter from Velerie Emerton, Administrator, German Home, Inc., Lawrence, MA to author July 3, 1991. 
CONCLUSION

Several historians, all familiar with New Hampshire history, upon learning the nature of this project, immediately asked, "there were Germans in Manchester?" The overwhelming presence of Franco-Americans in Manchester submerged other immigrant groups in common perceptions. In Lawrence, recognized for having many immigrant groups, the Germans are all but forgotten. Nevertheless, not only did Germans live in Manchester and in Lawrence, they also developed vibrant ethnic communities. The story of the founding, growth, and eventual disappearance of the German ethnic communities has been presented here.

For the German-Americans of Manchester and Lawrence the challenges of maintaining their German heritage while becoming American best describes their history. The fact that they could preserve their small islands of Deutschtum surrounded by so many non-Germans is a testament to their dedication. In the end, however, they were absorbed by the larger American culture and their islands of Germanness disappazad.

During the first one hundred and eighty-seven years of German emigration to the United States hardly a German had settled in Manchester or Lawrence. However, between 1870 and 1900, several thousand arrived to take advantage of 
opportunities in the mills that made the two cities the world's largest textile producing centers. Between 1880 and 1890, when emigration from Germany was at its highest, the majority of emigrants to the United States came from northeastern Germany. However, textile workers from Saxony and silesia arrived from those depressed textile producing provinces, with skills in demand in the mills of Manchester and Lawrence. Saxons, whose emigration rate may have been lower than the German average, clearly dominated the German immigrants in Manchester and Lawrence.

These Germans arrived in cities where there had been no German communitjes before them. They set about establishing churches and Vereine to foster German culture, language, and religion. German service businesses soon developed. Small sections of the cities took on a Germanic flavor--"Dutch Gap" in Lawrence, and the "West Side" in Manchester. Never exclusively German they were home to Germans, the places where they built their Vereinshallen, German churches, and German schools. They resembled Kleindeutschland or "Over the Rhine" in miniature. Germans in Manchester and Lawrence created a Vereinsleben as vibrant as that in any American city with a large German population. In fact, there were more clubs per German in Manchester and Lawrence than in st. Louis or Cincinnati.

Moreover, the German enclaves, the Vereine, the German churches, and Deutschtum lasted much longer in Manchester and Lawrence than they did in other cities in the United States, 
even cities with very large German populations. Several important reasons for this have been shown.

The predominance of immigrants from the same small area of Germany helps explain the continuation of Deutschtum. Former Saxons, mostly from the smaller towns, made up the majority of Germans in Manchester and Lawrence. Furthermore, many came from the same villages south and west of chemnitz. Family members, who arrived first, helped other family members arrive, settle in, and find jobs. The familial relationships tended to strengthen the common bond of ethnicity--both German and Saxon. It was as if a province of Germany had been transplanted to small industrial cities in America.

The continued leadership of the first-generation immigrants in the Vereine until the 1920 s and 1930 s kept Deutschtum alive in Manchester and Lawrence much Ionger than in many larger cities. Influential first-generation business and club leaders served as officers in the vereine into the 1920s and 1930s. Additionally, many of the children of the original club founders and leaders then assumed leadership and kept the Vereine alive for several more years. Familial patterns of leadership and membership existed. Often members from the same families exercised leadership in a number of different clubs and in the city-wide German organizations for years.

The existence of one German-Language newspaper, Anzeiger und Post, throughout the whole period also helps explain the 
continued Deutschtum. The paper publicized and supported German club, school, and church events. The paper contained a multitude of advertisements for club activities. It was a vehicle for communicating and keeping peutschtum alive.

That the Anzeiger und Post existed for sixty years is quite an accomplishment, since most German-language newspapers, even in cities with much larger German populations, ceased publication during or right after World War I. The union of the German-language newspapers of both cities created the Anzeiger und Post. Operated by two former residents of Glauchau, Saxony, Hugo Dick and Max Trumpold, it remained in their families until its demise in 1942. The Anzeiger und Post could be considered progressive. It opposed Prohibition and immigration restriction, and it favored the workers during the 1912 strike in Lawrence. It praised German language and culture and extolled the GermanAmerican, while, at the same time, it extolled American citizenship and freedom.

German-Americans in Manchester and Lawrence created a middle class existence for themselves. No real elite existed such as the Buschs in St. Louis or the Gambles in Cincinnati. Many held skilled and supervisnry positions in the textile mills, and had since they first arrived, having transferred textile skills from Germany to America. Others operated small shops, service businesses, building trades, and production facilities, such as sausage or cigar making. A few became professionals, in medicine, pharmacy, law, music, 
and teaching. From the middle class came the leaders of the Vereine.

Germans reached their highest proportion of the American population in 1900, and this also marked their greatest influence as an ethnic group. At that time the GermanAmerican National Alliance formed to represent Germans and to celebrate "German-ness." Not to be outdone, German-Americans in Manchester and Lawrence joined the national group and celebrated Deutschtum. They formed city chapters of the German-American National Alliance, and received visits from the national president. German-Americans in the textile cities, outside the "German belt," became involved in the national organization, while the National Alliance felt it important to include all German-Americans under its umbrella. Importantly, Deutschtun in Manchester and Lawrence did not end during world War $I$. In fact, the war fostered unity among diverse German elements. In 1916, "club" Germans joined Protestant and Catholic Germans to raise money for German widows and nrphans. The unity continued after the war. Such unity of purpose existed among German-Americans in very few other American cities. In some cities GermanAmericans were never able to overcome religious animosities from the old world. The small size of the cities and the smallness of the German-Communities fostered this cooperation. Leaders and club members likely knew the leaders and members of other groups and were more willing to cooperate. The smallness of the German community may have 
meant that German ethnicity became a more important bond than it did in other cities. The ability to join together also indicates a putting aside of old-world animosities for more American ideas.

Manchester and Lawrence exhibited very little antiGerman hysteria during World War $I$, so little, that during the summer of 1918, a regional Turnfest was held in Lawrence. Vereinsleben also continued unchecked during the war. Citizens of Lawrence and Manchester conducted no intolerant outbursts and changed no street names. In some cities, notably cincinnati and Chicago, anti-German hysteria may have been convenient covers in battles for political control. In Manchester and Lawrence, the Germans were neither a political threat to the established order nor a powerful voting block able to swing elections. Thus, one excuse for anti-German hysteria did not exist. Additionally, the local Englishlanguage press was reasonable in its war coverage and sensitive to the local German citizens.

In the two cities, the Vereine, the German churches, and the German-Schools made valiant efforts to preserve the German language. But, early on, German-Americans recognized the primacy of English in employment and commerce. As much as they wanted their children to be able to speak two languages, and to be able to read the German classics in order to better understand German culture, they knew that English was important for success. Moreover, most children attended public school and avoided the extra German language 
classes in the afternoons and evenings. Eventually, not enough children learned the language to maintain a linguistic island.

German Presbyterian churches in both Manchester and Lawrence exerted the most influence in the religious life of the German residents. This is unusual, since most scholars associate Lutheranism and Catholicism with Germans. However, in Lawrence a German Lutheran church did not exist until the 1930 s and the one in Manchester was apparently a relatively small congregation. German Catholic parishes did exist in both cities, blt they were not as influential as the Presbyterian churches. However, the German Presbyterian churches in both cities took the lead in fundraising activities, and in uniting with other protestant denominations and the catholics. The presbyterians joined with the Vereinsdeutschen, and the Lawrence church usually made the largest contribution, of any organization, to the German school. Additionally, the most influential members of the German community attended the German Presbyterian churches.

Between the world wars, Vereinsleben continued to thrive in Manchester and Lawrence. However, indications of change existed. Although attendance at many events was high, the actual supporters of Deutschtum represented only a small percentage of the total German-American community. English was used in both the Vereine and for church services. clubs began to lose their German purpose and admitted non-Germans. 
Marriages by Germans outside the ethnic group increased during the 1920 s and 1930s. Few new immigrants, who could rejuvenate clubs, arrived in the cities. Furthermore, Germans began moving out of their enclaves and the cities.

Nazi Germany presented new issues. Concerns soon replaced initial pride in the resurgent Germany. Ambivalence characterized the editorial policy of the Anzeiger und Post, but it was worried about Hitler, and was clear that German politics did not belong in America. German-Americans in Lawrence and Manchester had no interest in the (Nazi) GermanAmerican Bund.

Another war with Germany assured the end of Deutschtum in Manchester and Lawrence. The Anzeiger und Post ended publication during its sjxtieth year in 1942. The German churches dropped the designation "German" or changed their names entirely and ended services in the German language. Increased educational and home ownership opportunities brought on by the G.I. Bill accelerated the outmigration from the German neighborhoods after World War II. The dedication of a small number of second- and third-generation GermanAmericans kept some of the clubs alive into the 1970s, but the clubs became less clearly German and more social, and more and more non-Germans joined. Most clubs either dissolved or became purely non-German social clubs. To return to the metaphor used earlier, the GermanAmericans occupied small islands surrounded by a vast sea of non-Germans. The sea was primarily Anglo-American, Irish- 
American, and French-Canadian. Later Italian-Americans, Greek-Americans, Polish-Americans, and Portuguese-Americans entered the sea. The German islands, their neighborhoods, were not large, where one could walk for blocks and meet only other Germans, where one could hear only German spoken, where one could work surrounded only by Germans, or where one could sell to only Germans. Their small enclaves, while largely German, were never exclusively German. On the same block lived Germans, Irish, and French-Canadians. Working in the Amoskeag, the Wood, or the Arlington Mills required that they sork with non-Germans. Their stores, while selling to Germans, were willing to sell to non-Germans, and probably depended on them for a good portion of their business. In short, the Germans of Manchester and Lawrence had to adapt to life in an multi-ethnic, urban setting. And, in adapting they became more American. Their distinctive neighborhoods disappeared. They had been changed in the melting pot. As valiantly as they tried, they could not hold back the tide of assimilation.

Finally, the seas of assimilation quietly washed over the islands of Deutschtum. For a time small atolls remained, but they too were washed away. There are people who still remember the islands and atolls, but Deutschtum in Manchester and Lawrence has disappeared. 


\section{APPENAIX:}




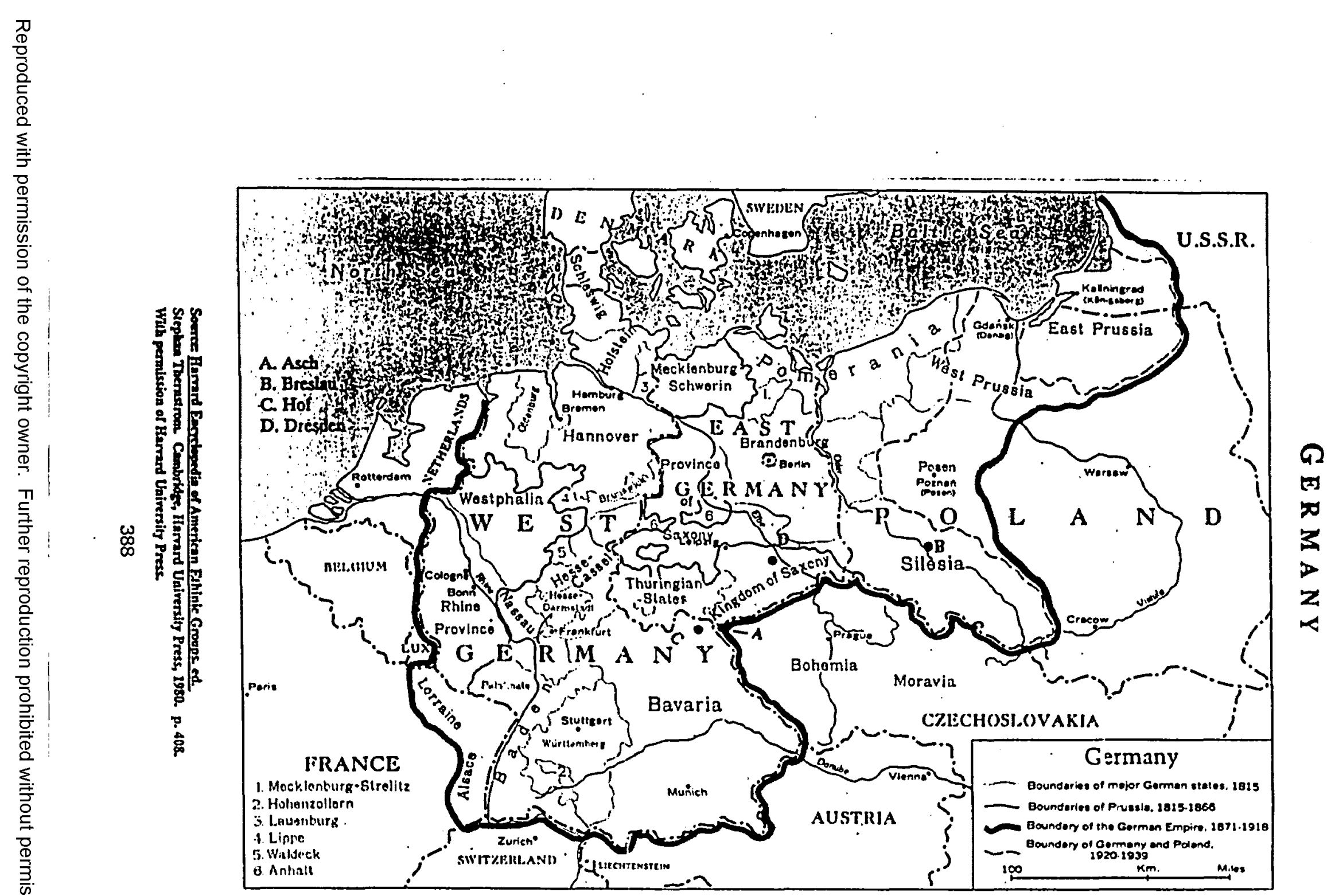




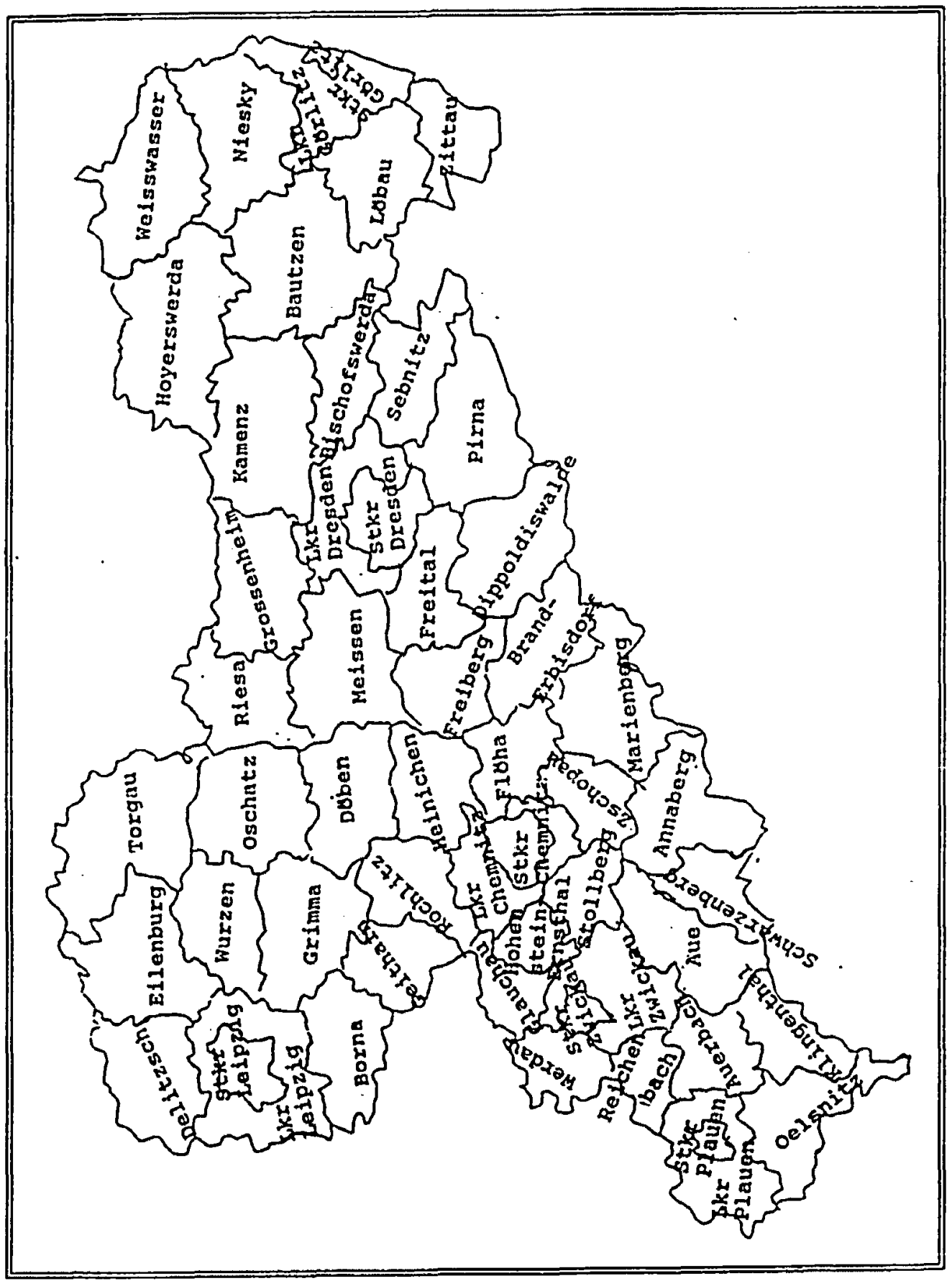

Districts (Landkreise) or Saxony. 
NEW E N G L A N D

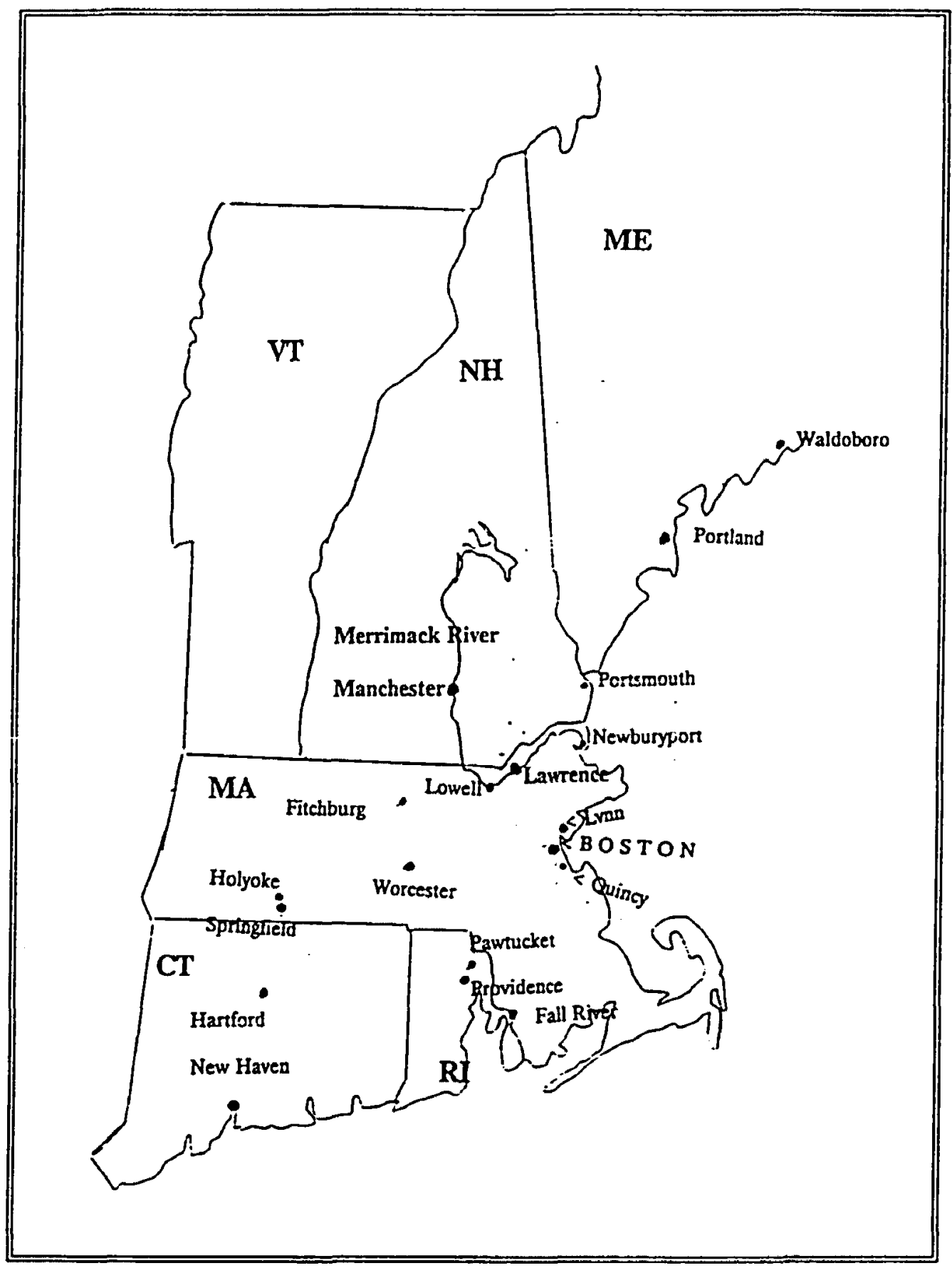

Cities with Germas popalations between 1870 an 1542 relerred to

in lext. Coloninl settlemeats of Waldoboro and Quincy noled.

Portland and Newbryport for reference referred 10 in lext. 


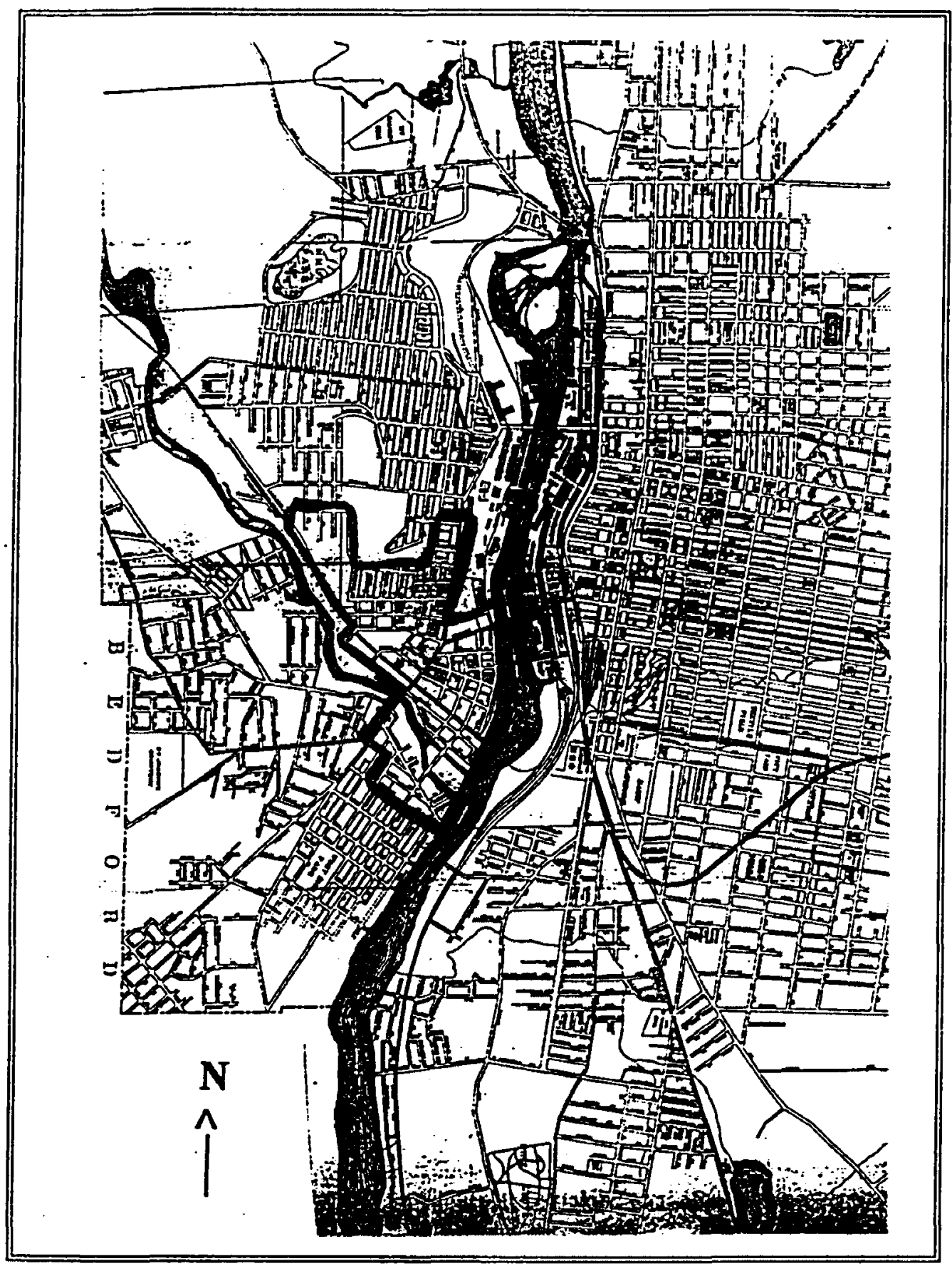

German discriat contine, (direa 1900).

Sourte Stmpson and Merdock, Co. Boston, MA

Manchester Historie Association Collection. 


\section{A W R E N C E}

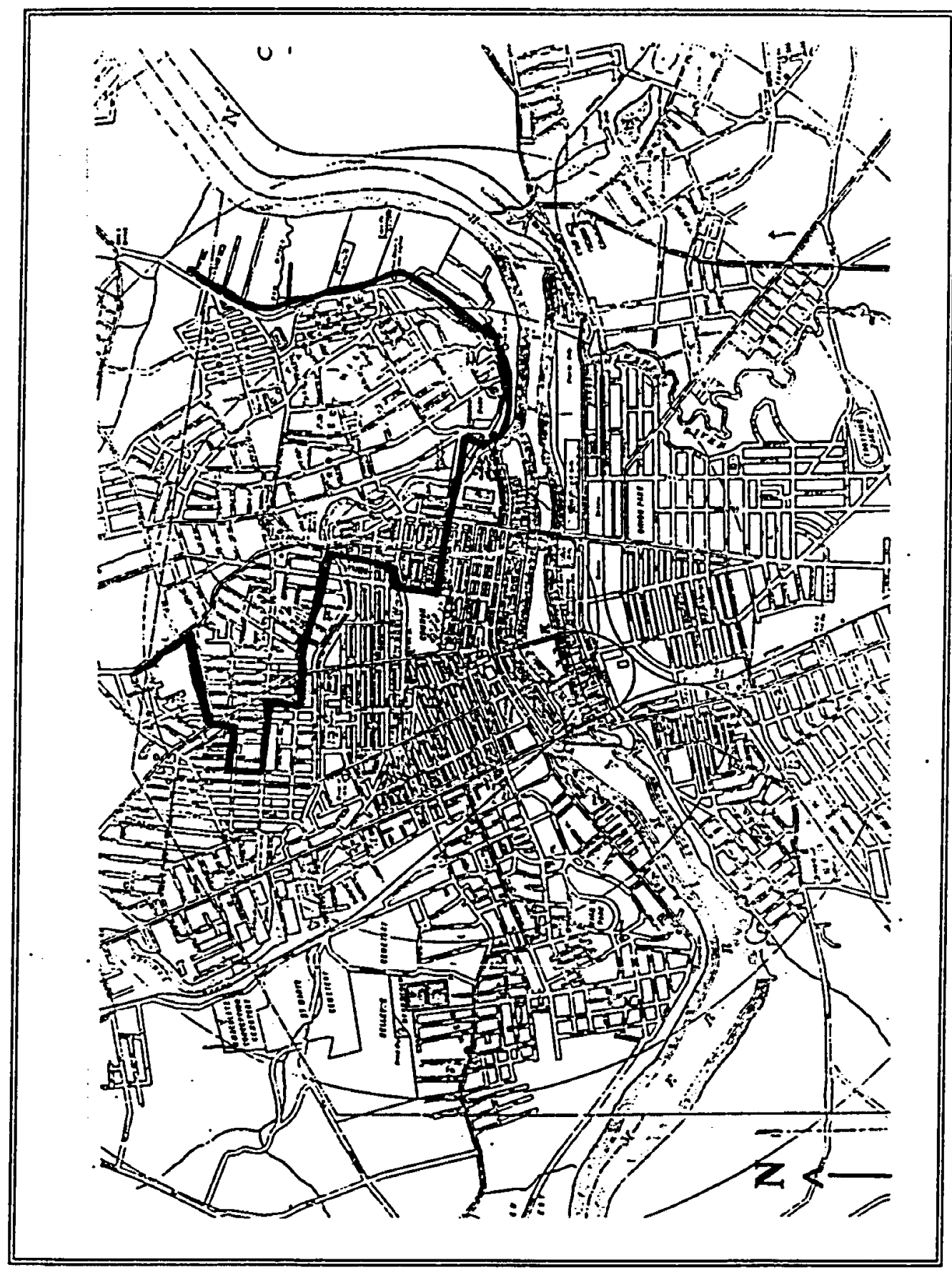

German district oulline, (ciro 150).

Source collection of Immigent City Arthires, Lumrence, MA. 


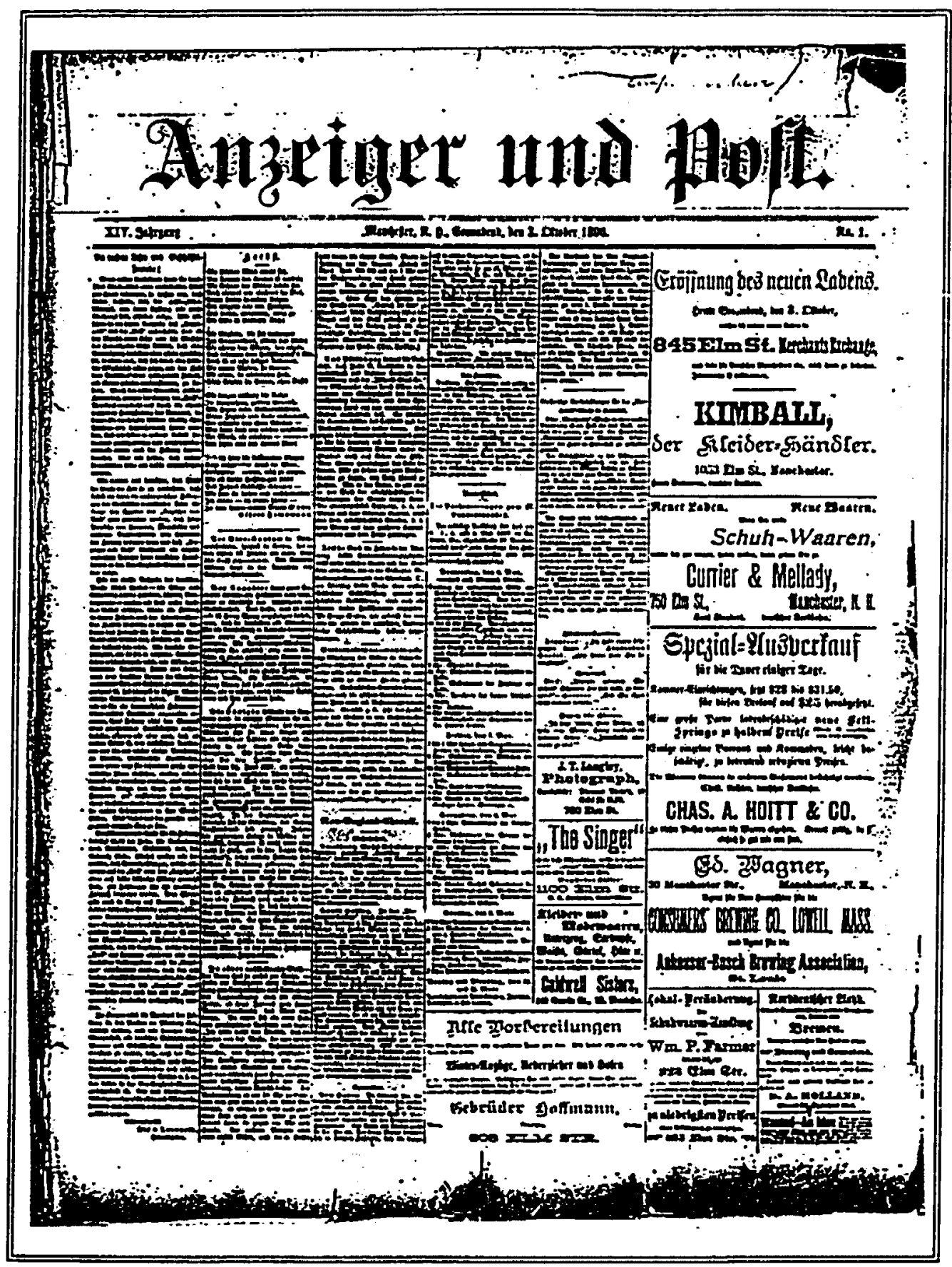

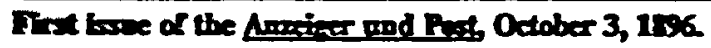

Nite Manchester, NH. Bepinaine m October 17, 1896 it was printed in Lumence.

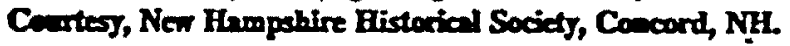




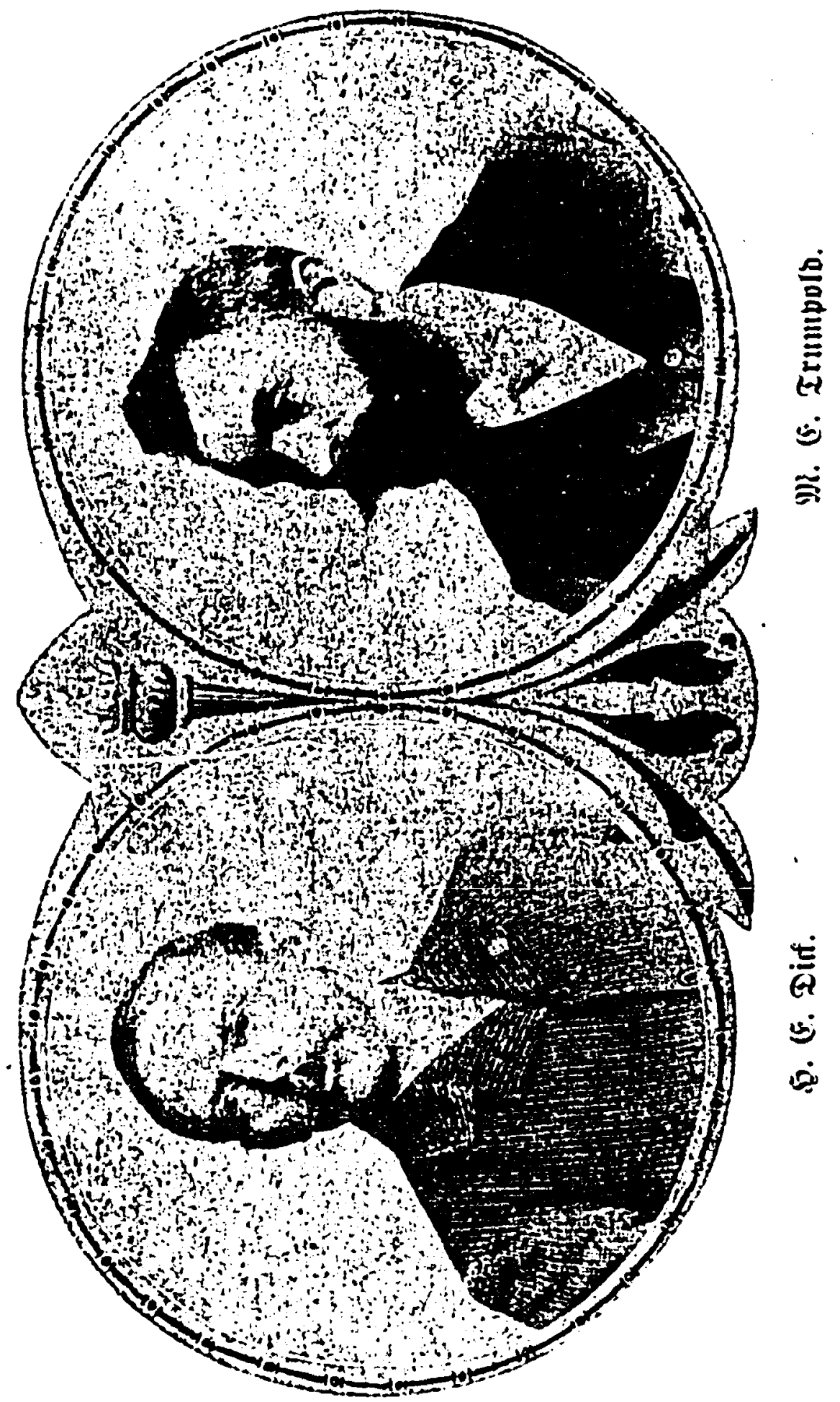

Hugo E Dick and Max E. Trumpold.

Co-owners and editors of the Anzeiger und Post.

Source: Anzeiger und Post, February 8, 1908.

Courtesy, Peabody Essex Museum, Salem, MA. 


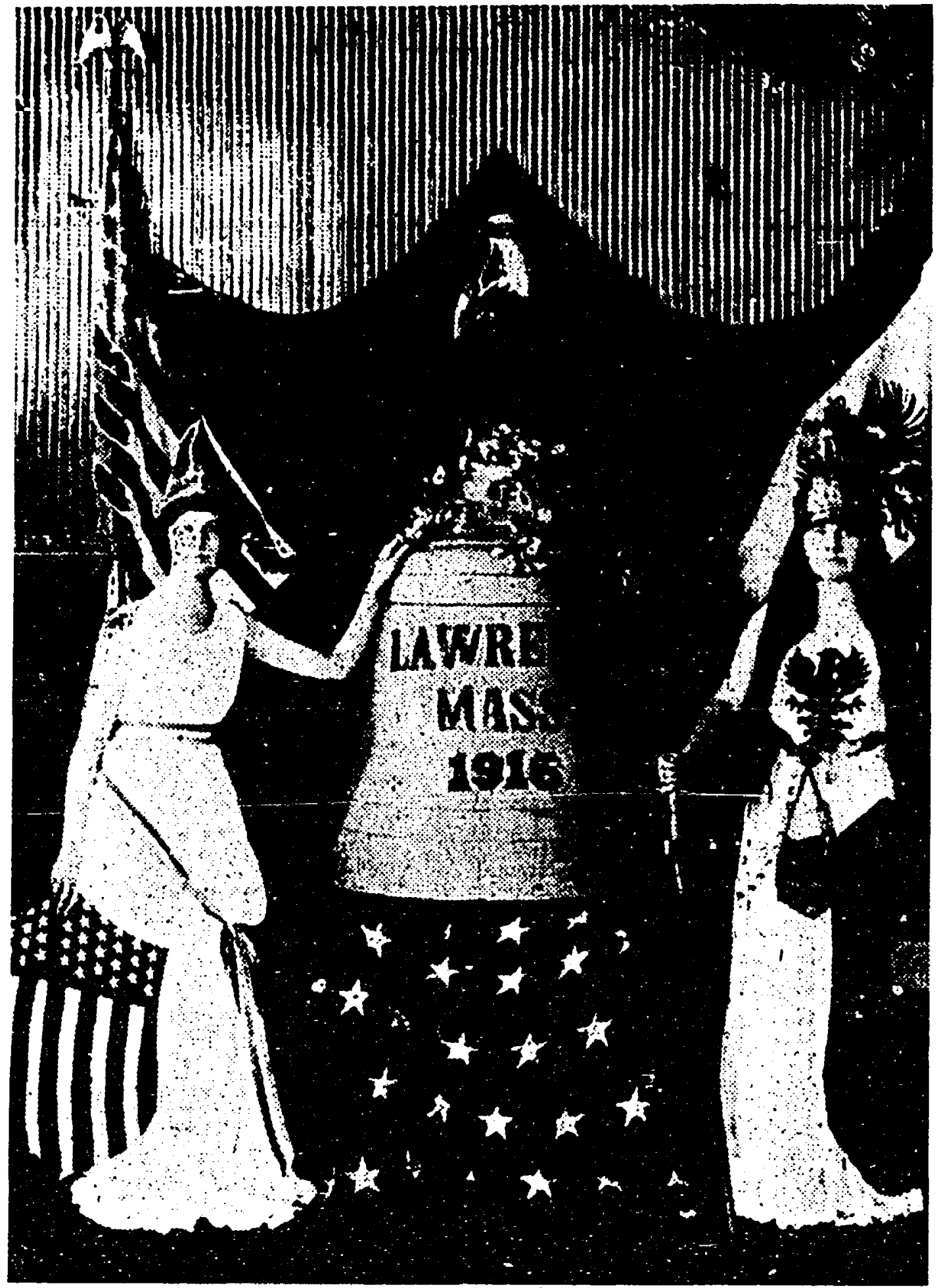

"Living Picture, Liberty and Germania," Deutsche Woche, Lawrence, 1916. Cora Trumpold (1) Gretchen Beilig (r). Source: Anzeiger und Post, August 26, 1916. Courtesy, Peabody Essex Museum, Salem, MA. 


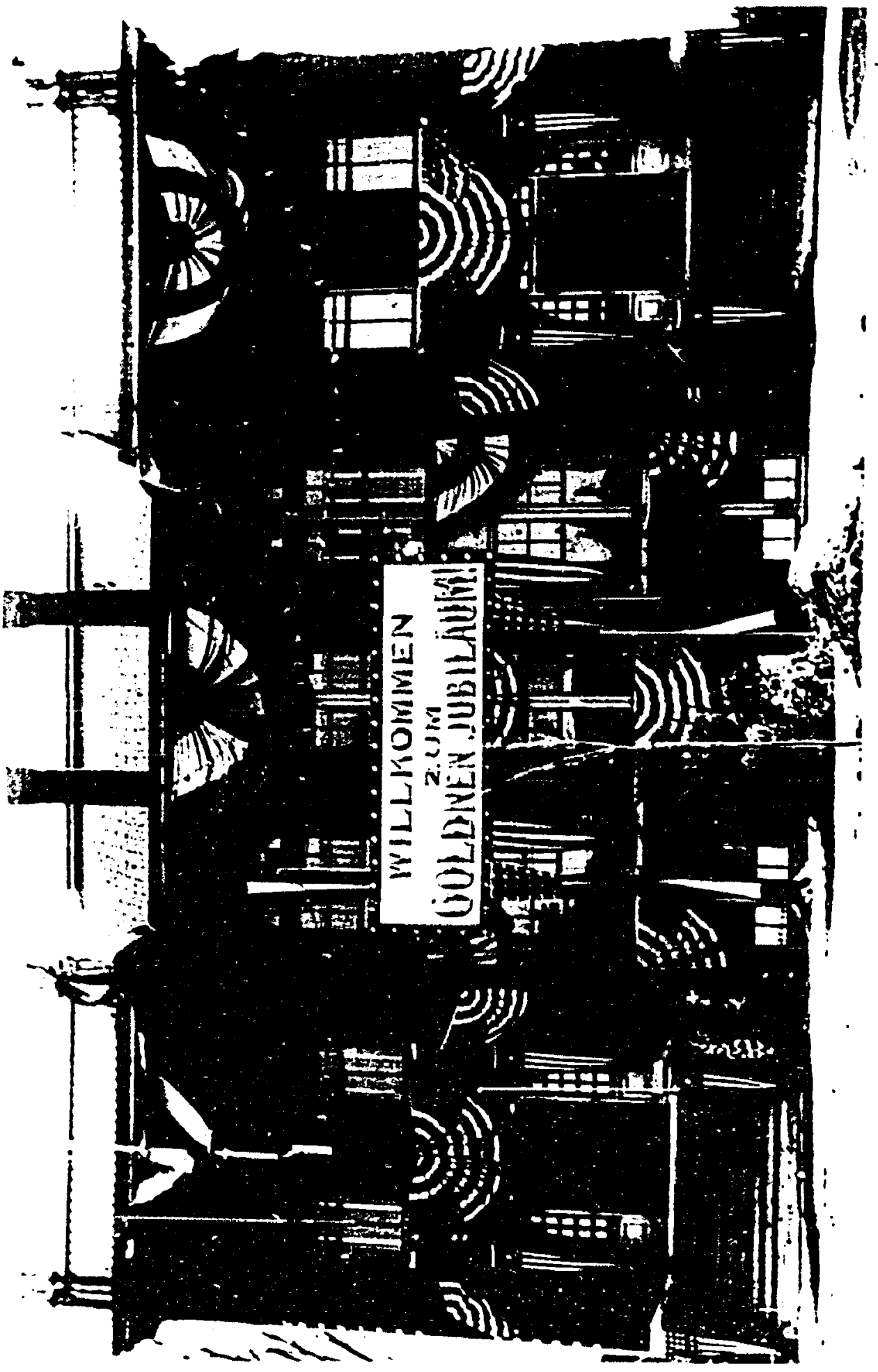

Turnhalle, Lawrence, (1916).

Collection of Immigrant city Archives, Lawrence, MA. 


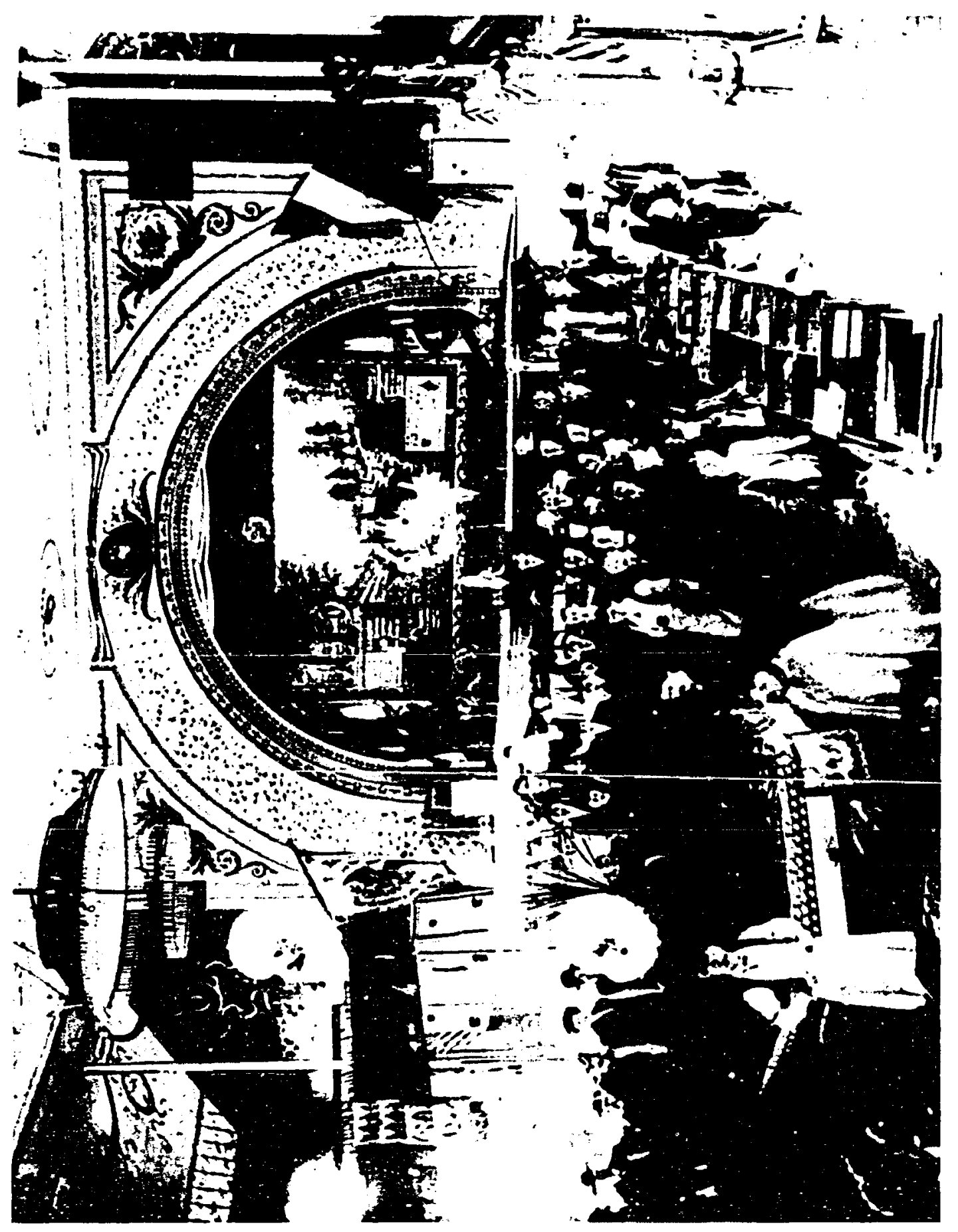

Turnhalie, Lawrence, (circa 1916).

Collection of Immigrant City Archives, Lawrence, MA. 


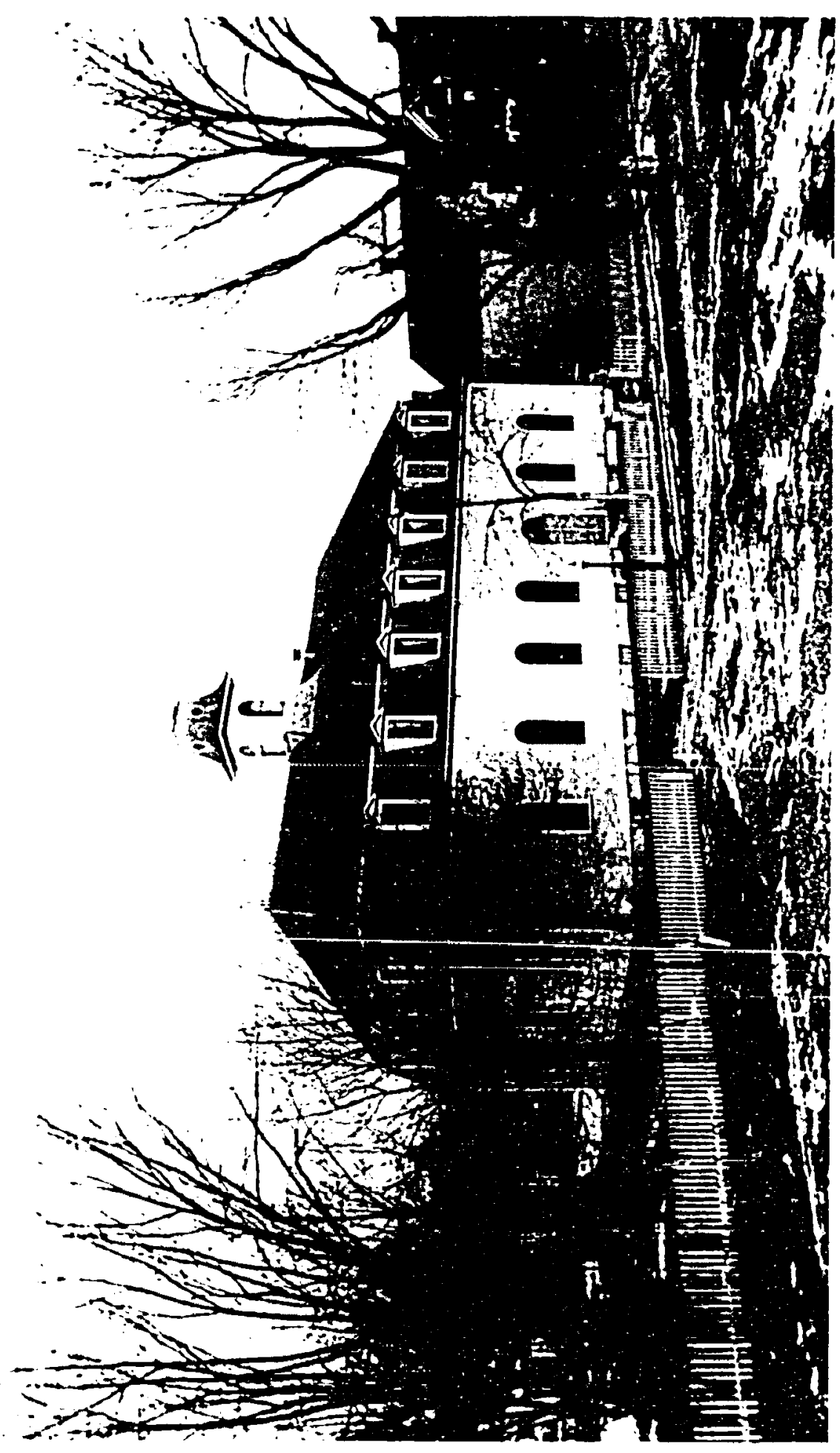

First Turnhalle, Manchester, (circa 1900).

Collection of the University of New Hampshire. 


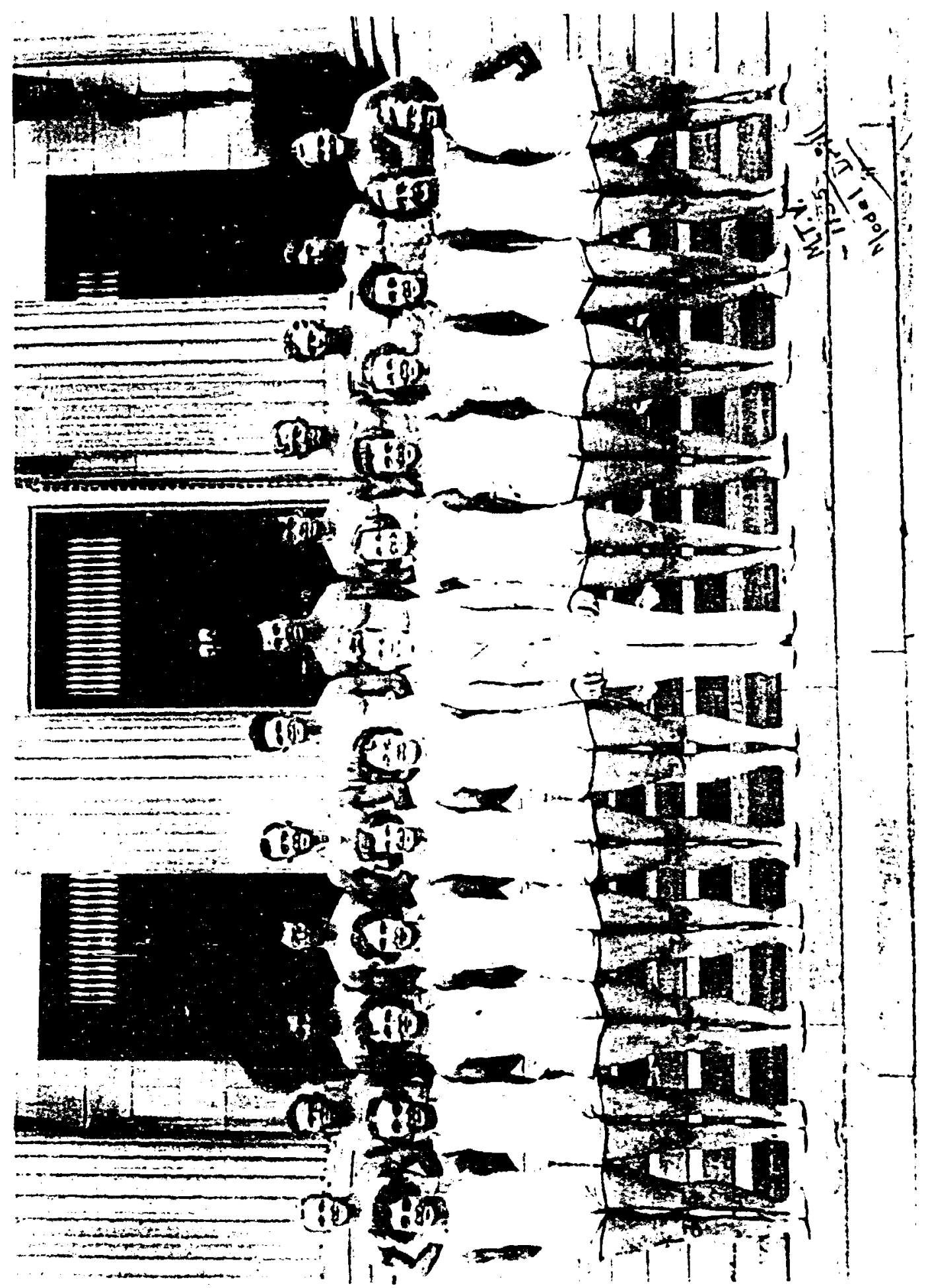

Menchester Tumers, 1935. Wimers of the Iurnfest in Springfield, Massachusetts.

In the front is instructor A. G. Robert Sandtam. Next to him to the right is Madge Poehlman,

loter Sandmam. Collection of the University of New Hanpshire. 
BIBLIOGRAPHY

ARCHIVAL COLLECTIONS

Assumption B.V.M. (Mariahimmelfahrt), Lawrence, MA. Baptismal Records, 1916-30

Marriage Records, 1917-1950

one Hundredth Anniversary Book

German (First) Presbyterian Church, Manchester, NH.

Minutes of the Session, 1882-1930, and Church Reqister, 1882-1930.

Minutes of the Session, 1935-47.

Trustees Minutes, 1939-1947.

Constitution and Protokol Buch des Jugend Vereins, 19171929 .

Protokol Buch des Jugend Vereins, 1917-1929.

Dues and Account Book, 1899-1932

one Hundredth Anniversary Booklet, 1972 .

Immigrant City Archives, Lawrence, MA. Files and collections. (ICA)

Manchester City Library. Files and Collections. (MCL)

Mancester Historic Association. Files and Collections. (MHA)

st. Anselm's College, Manchester, NH Archive Collections.

St. Raphael Parish, Manchester, NH.

Marriage Reqister, 1888-1920.

Register of Deaths, 1888-1926.

Centennial Souviner Edition, 1888-1988.

CENSUS DOCUMENTS

us Census office.

Eighth Census, 1860 , Population. Vol I, 1964.

Manuscript Schedules for Lawrence and Manchester.

Ninth Census, 1870 , Population. Vol I, 1872.

Manuscript Schedules for Lawrence and Manchester.

Tenth Census, 1880, Population. Vol XVIII, 1886. Manuscript Schedules for Lawrence and Manchester.

Eleventh Census, 1890, Population. Vols I \& II, 1895-7. Manuscript schedules for Lawrence and Manchester. 


\section{U.S. Bureau of the Census.}

Twelfth Census, 1900, Population. Vols I \& II, 1901-02.

Manuscript Schedules for Lawrence and Manchester.

Thirteenth Census, 1910, population. Vols I \& II, 1913. Manuscript Schedules for Lawrence and Manchester.

Fourteenth Census, 1920 , Population. Vol I, 1924. Manuscript schedules for Lawrence and Manchester.

Fifteenth Censis, 1930, population. Vol III, 1932.

Sixteenth Census, 1940, Population. Vols I \& II, 1942.

Seventeenth Census, 1950, Population. Vol II, 1953.

Eighteenth Census, 1960, Population. Vol I, 1963.

U. S. Bureau of the Census. Historical Statistics of the United States: Colonial Times to 1970. Vols I and II, 1975.

GOVERNMENT DOCUMENTS AND REPORTS

Lawrence, MA.

Annual Report, city of Lawrence.

Assesors' street Lists.

Records of Elections.

Manchester, NH.

Annual Report, City of Manchester. John B. Clark, Publisher.

Assessors' Lists.

ordinances, public statutes, and special Acts. Lew A. Cummings, Co.

Register of Marriages.

Commonwealth of Massachusetts.

Report of A Special Commission to Investigate Activities Within this Commonwealth of Communistic, Fascist, Nazi, and othex Subversive organizations. Boston: Commonwealth of Massachussets, 1938.

State of New Hampshire.

Journal of The Senate of New Hampshire, Concord, NH. 1915.

Manual for the General Court. Concord, NH. Numbers 3 to 38 , published every odd numbered year from 1893 to 1963.

The New Hampshire Manual for the General Court 1680- 
1891. Concord, NH 1891.

United States Department of state. Diplomatic Records of the United states: Dispatches from United States

Consuls.

Annaberg (T529)
Berlin (T163)
Bremen (T104)
Carlsbad (T540)
Chemnitz (T380)
Dresden (T383)
Glauchau (T572)
Hamburg (T261)
Leipzig (T215)
Munich (T261)
Plauen (T536)
Prague (T663)
Zittau (T709)

PRIVATE AGENCY REPORTS

Amoskeag Company Records. Manchester Historical Association and Baker Library, Harvard University Graduate School of Business Administration.

Amoskeag Manufacturing Company.

Employee Room Register. Showing boarding address and place of origin, 1854-1878. 1 Vol (MHA \# 84.)

Payroll Book, "New Mills, Number 5, 'g,' 1879-1880. (MHA)

R.G. Dun \& Company Collection. (Massachusetts \& New Hamshire). Baker Library. Harvard University Graduate School of Business Administration.

Essex Company Records, (ICA)

Julius B. Emmert \& Sons, Lawrence, MA, Private Records.

Schunland Company, Private Papers of Mrs. Van Loan.

GERMAN CLUB RECORDS, HISTORIES, AND PRINTED PROGRAMS

American Turners.

Annual Report, 1936-37.

Directory of National Council, District Councils, and Society Leaders. 1985. 
Bavarian Reading and Progressive Society, (B.L.U.F.V),

Lawrence.

Twenty-fifth Jubilium Program, 1915.

Fiftieth Anniversary Program, 1940 .

one Hundredth Anniversary Book, 1890-1990.

Protokol Buch, 1898-1910.

Brunhilda Lodge, O.d. H. S., (Hermann's Sons) Lawrence.

Minutes of Golden Anniversary, 1946 .

Minutes, 1931-49.

Miscellaneous Correspondence.

Concordia Schützenverein, Lawrence.

Sixtieth Anniversary Program, 1886-1946.

Protokol Bücher, Club records and secretary reports, 1892-1940.

kassierer Buch, 1892-1919.

Deutsche Woche, Fest Programm, 17-20 August 1916, Lawrence.

Deutsch-Amerikanisches National Bundes der Ver. S. v. A. Protokol, 2-6 oktober, 1909, Massachusetts Report.

Deutsche Presbyterian Kirche, Lawrence.

Funfzigiuhriges Jubil tum Buch, 1876-1926.

One Hundredth Anniversary Book, 1976. (As Christ Church).

Deutsches Freibett Kommitee, Lawrence.

Protokol Bücher and contribution lists 1892-1917.

Protokol Bücher, 1917-41.

Evangelical Lutheran Church of the Redeemer, Lawrence. Twenty-fifth Anniversary Booklet, 1930-1955.

German American Singers, Lawrence.

German Relief Program, May $4,1947$.

German Order of the Harugari, Barbarosa Lodge, 329, Manchester.

Acts of Incorporation, 1875.

German School Association of Lawrence (Allgemeinische Deutsche Schule), Lawrence.

Protokol Buch, 1889-1901.

Protokol Buch, 1900-1916.

protokol Buch, 1936-1949.

Protokol über das 50 Juhrige Jubilaum, 1925.

Fiftieth Anniversary Minutes, 1925.

Sixtieth Anniversary, 1875-1935, Souvenir Edition.

Seventieth Anniversary, 1945.

German School Society of Manchester.

Constitution, unpublished. (MHA) 
History, unpublished. (MHA)

Yearly programs. (MHA)

Gesangverein Lyra, Lawrence.

Statuten, 1980 .

Minutes, 1915-1931.

Harmonie Lodge \#5 O.d. H. S, (Hermann's Sons), Lawrence.

Protokol Buch, 1892-1898.

Golden Anniversary, 1892-1942.

Miscallenous Correspondence, (ICA).

Lawrence Turn Verein.

One Hundredth Anniversary Program, 1866-1966.

Diamond Jubilee Program, 1866-1941.

50 Jahriges Jubilaum, Program, 1916.

Manchester Turn Verein, Inc.

One Hundredth Anniversary 1870-1970, Souvenir Edition.

Private Papers of Madge Sandmann.

Neu England Staaten Sangerfest.

Proqramm Buch, 1936.

Gymnastic and singing Festival, 1924.

ordens der Harugari.

Grosslogen Massachusetts Buch, 1929-30.

Harugari Hall Dedication Book, 1912 Lawrence.

Workman's Relief Association, (Arbeiter Krankenunterstützungs

Verein, or A.K.U.V.), Manchester.

Contributions and Payment Record Books.

JEWISH SOCIETIES, PRINTED PROGRAMS, YEARBOOKS

Associated Clubs, YHMA, Lawrence.

Fourth Annual Black and White Review, 1935.

Hebrew Ladies Free Loan Association, Lawrence. "The Lacht Nacht, 1936, (sic), play program.

Senior Hadassah, Lawrence Chapter. 1940 and 1941 Yearbooks.

JEWISH HISTORIES AND MEMOIRS

Franklin, Dana, and Hymie Axelrod, R. Zidle and Shirly Hymanson. History of the Jews of Lawrence. Lawrence MA: private printing, 1978. (ICA) 
Goodwin, George M. "Sketches of the Lawrence Jewish Community." North Andover, MA: Temple Emanuel, 1990. (ICA)

Stern, Julius. "From Herzenbrock in Germany to Andover, Mass; Autobiography of Julius stern of Marum Knitting Mills, Lawrence, MA. (ICA)

\section{DIRECTORIES}

American Newspaper Annual and Directory. N.W. Ayer and Sons. Philadelphia. 1917, 1921, 1926, 1930, 1936, $1940,1943,1945$.

The Boston Directory. George Adams, Co. Boston. 1850 and 1851.

Lawrence City Directory. Sampson and Murdock, Co. Boston, MA. $1860,1870,1875,1880,1885,1890,1895,1900$, $1905,1910,1915,1917,1918,1920,1925,1930,1935$, $1940,1942,1943,1945,1950$.

Manchester City Directory. Sampson and Murdock, Co. Boston, MA. $1860,1866,1870,1875,1880,1885,1890,1895$, $1900,1905,1910,1915,1917,1918,1920,1925,1930$, $1935,1940,1943,1943,1950$.

Methuen city Directory. Union Publishing Company, Boston, MA. $1911,1916,1921,1926,1931$.

\section{NEWSPAPERS}

L'Avenir National, Manchester, NH, 1916-18.

Anzeiger und Post, Lawrence, MA.

Started in 1883 as Lawrencer Anzeiger, which is available 1887-1891 at the Manchester Public Library. In 1896 it merged with the Manchester Deutsche Post forming the

Anzeiger und post, which is available as follows:

1896-1899, New Hampshire Historical Association, Concord, NH, and Manchester Public Library.

1900-1933, Peabody Essex Museum, James Duncan Philips Library, Salem, MA.

1934-39, Institut für Auslandsbeziehungen Bibliothek, stuttgart;

1942, New England Repository, Cambridge, MA.

All years are not complete.

Crimmitschauer Anzeiger, Crimmitschau, Saxony. 
Lawrence Eaqle Tribune.

Lawrence Telegraph.

Manchester Leader.

Manchester Union Leader.

New Hampshire Sunday Times.

Der Deutsche Pionier, Cincinnatti, OH.

Dex Pionier. Boston, Ma.

Werdauer Heimatblutter. Werdau, Saxony.

PUBLISHED CONTEMPORARY WORKS

Adams, Henry Baxter. The Germanic origin of New Enqland Towns. Baltimore: Johns Hopkins University, 1882 . (New York: Johnson Reprint Co, 1973).

American Woolen Company 'Employee Booster'. American Woolen Company, Lawrence, MA. Published monthly, 1919-1922 (?).

American Woolen Company. Shawsheen: The World's Woolen and Worsted Centre; The Model Community and Home of the offices and Staff of American Woolen Company. Andover, MA, 1924 .

Amoskeag Bulletin. Amoskeag Textile Club, Manchester, NH. Published twice a month 1912-1921.

Amoskeag Manufacturing Company, History of the Amoskeag Strike During the Year 1922. Manchester: Amoskeag Mfg. Co., 1924 .

Amoskeag Manufacturing Company. Views and sketches of the Amoskeag Manufacturing co. Manchester: Amoskeag Mfg. Co., 1920 ?

"Die Auswanderer Registrierstation in Leipzig." Illustritre zeitung. No. 3281, (17 Mai 1906): 782

Bartoldt, Richard. Fxom steerage to Congress. Philadelphia: Dorrance and Company, 1930.

Beasley, Norman. Frank Knox: A Short Biography. Garden City, NY: Doubleday, 1936.

Bogen, F.W. The German in America: or Advice and Instruction for the German in the United states of America: also a 
Reader for Beqinners in the English and German Lanquages. Boston: B.H. Green, 1851, second ed.

"The Bolt in Cotton Textiles." Fortune. 36 (July 1947), 61-67 and 178-79.

Brown, George Waldo. The Amoskeag Manufacturing $\mathrm{Co}$. of Manchester, $\mathrm{NH}$ : A History. Manchester, NH: Amoskeag Manufacturing Co., 1915.

Bruncken, Ernst. "Germans in America." American Historical Association Annual Report for 1898 . Washington: Government Printing ofice, 1899, 345-55.

" How Germans Become Americans." Proceedings of the state Historical Society at its Forty-fifth Annual Meeting, 1897. Madison, Wisconsin: Democratic Printing, Co., 101-22.

Bushee, Frederick A. Ethnic Factors in the Population of Boston. New York: Arno Press, 1970. Originally published 1903.

Casson, Herbert N. "The Germans in America." Munsey's Magazine. 34 (March 1906), 694-707.

The Century. "The German American," 93 (April 1917): I. Walter Wolke, "Confessionas of a Hyphenate," 929-934. II. Kuno Francke, "The Present Duty of German-Americans," 734-5.

Chafee, Zehariah. Free speech in the United states. Cambridge: Harvard University Press, 1941.

Clark, John B. Manchester: A Brief Record of its Past and a Picture of its Present. Manchester, NH: Mirror, 1875 .

Creel, George. "Our 'Aliens'--Where they Loyal or Disloyal?" Everybody's Magazine. (March 1919): 36-38 and 70-73.

"The Communist Column." Fortune. 22 (November 1940), 89, 104-109.

Davis-Dubois and Rachel Emma Schweppe, eds. The Germans in American Life. New York: Thomas Nelson Sons, 1936 .

Daniels, John. Americanization via the Neighborhood, New York: Harper and Brothers, 1920. (Patterson Smith reprint, 1971). 
Drogan, Maurice B. History of Lawrence. Cambridge, MA: Murray Printing, 1924.

- Lawrence, Yesterday and Today, 1845-1918.

Lawrence, MA: Dick and Trumpold, 1918.

"Fascists in the U.S." Fortune. 22 (November 1940), 85-87, 108-114.

Faust, Albert Bernhardt, The German Element in the United states. Boston and New York: Houghton Mifflin Co, 1909. 2 vols. (Reprint, Arno Press of New York, 1969)

"The Foreign Language Press." Fortune. 22 (November 1940), $90-93,102,104$.

Francke, Kuno. A German-American's Confession of Faith. New York: B.W. Huebsch, 1915.

"German Character and the German American." The Atlantic. (April 1926), 494-502.

"A German-American's Gethsemane." Literary Digest.

55 (November 3 1917): 51-53.

Goebel, Julius. "The Place of the German Element in American History." American Historical Association Annual Report for 1909. Washington: American Historical Association, 1911, 181-190.

"A Growing Demand for the Suppression of the Gerinan American Press." Current opinion. 63 (September 1917): 151-152.

Hagedorn, Hermann. "The Menace of the German-Language Press." The outlook. 116 (August 15, 1917): 579-581.

"Hot-Shot from a German-Born American." Literary Digest. 58 (August 24, 1918): 23-24.

Hourwich, Isaac A. Immigration and Labor: The Economic Aspects of European Immigration to the United States. New York: G.P. Putnam's Sons, 1912, (Arno Press, 1969 Reprint).

Hurd, D. Hamilton. Comp. History of Essex Colinty. Vol I, Philadelphia: J.W. Lewis \& Co., 1888 .

Kapp, Friedrich. The Life of Frederick william von steuben, Najor General in the Revolutionary Army. New York: Mason Brothers, 1859 .

KOrner, Gustav Philip. Das Deutsche Element in den Vereinigten staaten von Nordamerika, 1818-1848. New 
York: Peter Lang, 1986. (originally published 1880).

Krueger, Max. Second Fatherland: The Life and Fortunes of $A$ German Immigrant. ed. Marilyn McAdams Silby. College Station: Texas A \& M University Press, 1976.

Kunhardt, George E. Lawrence: A Manufacturer's View. Boston: The Rockwell and Churchill Press, 1919.

"Lawrence Revives--Part Way." Business Weeek. (June 10, 1950), 61-62.

Lawrence up to Date, 1845-1895. Lawrence: Rushford \& Donoghue, 1895 .

Leading Citizens of Essex County Massachusetts: Biographical Review. Vol XxVIII. Boston: Biographical Review Co., 1898 .

Manchester, Yesterday and Today. Manchester, NH: Lew A. Cummings Co., 1946.

Mencken, H.L. "Die Deutsch-Amerikaner." Neue Rundschau. 39 (1928): 486-95.

1933), 506-510.

Metcalf, Henry Harrison. One Thousand New Hampshire Notables. Concord, NH: Rumford Press, 1929.

Maurer, Heinrich $\mathrm{H}$. "The Lutheran Community and American Society: A Study of Religion as a condition of Social Accomodation." American Journal of Sociology. 39 (September 1928): 282-295.

Munsterberg, Hugo. American Traits From the point of view of A German. Boston and New York: Hougton, Mifflin Co., 1901 .

"Nazi Agents in the U.S." Fortune. 21 (October 1946), $46-50,134-148$.

Nelles, Walter, comp. and ed. Espionage Act Cases. New York: National Civil Liberties Bureau, 1918.

"New England's New Look, Fortune. 48 (October 1933), 131-2.

New Hampshire Notables. Concord, NH: The Concord Press, 1932 .

Oberndorf, Ludwig. "The German Press in the Unites States." The American-German Review. 6 (December 1939): $14-16$. 
Olds, Frank Perry. "Disloyalty of the German-American Press." The Atlantic. 120 (July 1917), 136-140.

"Our Loyal German-Americans." Literary Digest. 58 (August 17, 1918): 20-24.

Park, Robert E. The Immigrant Press and its control. New York: Harper \& Brothers, 1922 .

Park, Robert E., Ernest Burgess and Roderick McKenzie. The City. Chicago: The University of Chicago Press, 1925.

Phil1sbury, Hobart. New Hampshire: A History.

(Biographies). V, 1-5, New York: The Lewis Historical Publishing Co., 1927-28.

Pictorial Manchester. Clarke, NH: The Mirror's Co., 1896.

Pohle, L. "Auswanderung und Auswanderungs Politik im konigreich Sachsen." in Auswanderungs Politik in Deutschland: Berichte. ed. E. von Phillopvich, 353-386. Leipzig: Verlag von Dunder und Humbolt, 1892.

Rosenthal, Hildegard. Die Auswanderung aus Sachsen im 19 Jahrhundert (1815-1871). Stuttgart: Ausland und Heimat Verlags, 1931.

Ross, Colin. Unser Amerika: Der Deutsche Anteil an den Vereinigten Staaten. Leipzig: F.A. Brockhaus, 1936.

Ross, Edward Alsworth. The old World in the New: The Significance of Past and Present Immiqration to the American People. New York: The Century Company, 1914.

Saunders, Dero "The Twilight of American Woolen." Fortune. 49 (March 1954), 92-96 and 198-204.

Schieber, Clara Eve. The Transformation of American Sentiment Toward Germany, 1870-1914. Boston and New York: Cornhill Publishing, Co., 1923.

Schlegel, Carl Wilhelm. Schlegel's German Families in the U.S.: Genealogical and Biographical. New York Edition. 3, vols. New York: The American Historical Society, 1916-18.

Schrader, Fredrick Franklin. The Germans in the Making of America. Boston: The Stratford, Co., 1924. 
Seabrook, William. "America über Alles." The American Magazine. (October 1937), 48, 49, 84-93.

"Try to Make Nazis out of Us." Current History. (June 1939), 22-23.

Spindler, George $w$. The Life of Karl Follen: A Study in German- American Cultural Relations. Chicago: The University of Chicago Press, 1917.

"Textile City Gets Along Despite Layoffs." Business Week. (May 7, 1949).

Thorp, L. Ashton. Manchester of Yesterday. Manchester, NH: Granite State Press, 1936.

Thwing, Charles Franklin. The American and the German University: One Hundred Years of History. New York: Macmillan, 1928.

Thomas, William A. old World Traits Transplanted. New York: Harper and Brothers, 1921. (Patterson Smith Reprint, 1971).

Thompson, Frank. Schooling of the Immigrant. New York: Harper and Brothers, 1920. (Patterson Smith Reprint, 1971).

"What the German-Americans are organizing For." Literary Digest. 50 (February 13, 1915): 299-301.

willey, George, Semi-Centennial Book of Manchester, 18461896. Manchester, NH: George F. Wiley Publishing, Co., 1896.

SECONDARY WORKS

Abramson, Harold. "Assimilation and Pluralism." in Harvard Encyclopedia of American Ethnic Groups. ed. Stephan Thernstrom, 150-160. Cambridge: Harvard University Press, 1980. Ethnic Groups. ed. Stephan Thernstrom, 869-875. Cambridge: Harvard University Press, 1980.

Achenbaum, W. Andrew. "Toward Pluralism and Assimilation: The Religious Crisis of Ann Arbor's württemberg Community." Michigan History. 58 (1975): 195-218. 
Adams, Willi Paul. "Die Assimilations-frage in der Amerikanischen Einwanderungs Diskussion, 1890-1930." in Auswanderer-Wanderarbeiter-Gastarbeiter: Bevolkerung, Arbeitsmarkt, und Wanderung in Deutschland seit der Mitte des 19 Jarhunderts. ed. Klaus J. Bade, 300-320. Ostfildern: Scripta Mercature, Verlag, 1984.

- "Ethnic Leadership and the German-Americans" in American and the Germans: An Assessment of a Three Hundred year History. eds. Frank Trommler and Joseph McVeigh, Vol I, 148-159. Philadelphia: University of Pennsylvania Press, 1985.

- The German Americans: an Ethnic Experience. Translated and adapted by LaVern $\mathrm{J}$. Rippley and Eberhard Reichman. Perdue, IN: Max Kade German-American Center, Indianapolis University, 1993.

Ahlstrom, Sydney E. A Religious History of the American People. New Haven: Yale University Press, 1973.

Ambrosius, Lloyd. "Ethnic Politics and German Amercian Relations After World War I: The Fight over the Versailles Treaty in the United states." in Germany and America: Essays on Problems of International Relations and Immiaration. ed. Hans L. Trefousse, 29-40. New York: Brooklyn College Press, 1980.

Anderson, Will. Beer New England. Portland, ME: private printing, 1988.

Applegate, Celia. A Nation of Provincials: The German Idea of Heimat. Berkeley: University of California Press, 1990 .

Arnold, Dexter P. "A Row of Bricks: Worker Activism in the Merrimack Valley Textile Industry, 1912-1922." PhD Diss. University of wisconsin--Madison, 1985.

Arndt, Karl. "Franklin's Lost Map of Germantown, Massachusetts." Pennsylvania Folklife. 31 (1981-82): 87-89.

Arndt, Karl, and Mary E. Olson German-American Newspapers and Periodicals, 1732-1955: History and Bibliography. Heidelberg: Quelle and Meyer, 1961.

Badal, James J. "The Strange Case of Dr. Karl Muck, Who was Torpedoed by the Star Spangled Banner during World War I." High Fidelity Magazine. 20 (October 1970): 55-60.

Bade, Klaus J. "Die deutsche überseeische Massenauswanderung im 19. und frühen 20 Jahrhundert: Bestimmungsfaktoren und 
Entwicklungsbedingungen." in Auswanderer-

Wanderarbeiter-Gastarbejter: Bevolkerung, Arbeitsmarkt, und Wanderung in Deutschland seit der Mitte des 19.

Jahrunderts. ed. Klaus J. Bade, 259-299. ostfildern: Scripta Mercature Verlag, 1984.

- "German Emigration to the United states and Continential Immigration to Germany in the Late

Nineteenth Century and Early Twentieth Centuries. " in Labor Migration in the Atlantic Economies: The European and North American Working Classes puring the period of Industrialization. ed. Dirk Hoerder, 117-142.

Westport, CT: Greenwood Press, 1985.

- "German Emigration to the United States and Continential Immigration to Germany in the Late Nineteenth Century and Early Twentieth Centuries." Central European History. 13 (December 1980): 348-377.

Bailey, Thomas $A$. and Paul B. Ryan. The Lusitania Disaster: An Episode in Modern Warfare and Diplomacy. New York: The Free Press, Division of Macmillan, 1975.

Bailyn, Bernard. The Peopling of British America: An Introduction. New York: Knopf, 1986.

Bailyn, Bernard, and Barbara DeWolfe. Voyages to the West: A Passage in the Peopling of America on the Eve of the Revolution. New York: Knopf, 1987.

Barkai, Abraham. "German Jewish Migration in the Nineteenth Century, 1830-1910," in Migration across Time and Nations: Population Mobility in Historical Contexts. eds. Ira Glazer and Luigi De Rosa, 202-219. New York: Holmes and Meier, 1986.

Barry, Colman J. The Catholic Church and German Americans. Milwaukee: The Bruce Publishing Co., 1953.

Bassett, John Spencer. "The Round Hill school." The Proceedings of the American Antiquarian Society. New Series, 27 (April 1917-October 1917): 18-62.

Baumgart, Claus and Falk Hoppner. "Sachsen in (Nord)Amerika, Biblio-Biographische Bemerkungen $2 u$ einen Fast Vergessenen Thema." Unpublished paper delivered to the Deutsche Gesellschaft für Amerikastudien, in Blaubeuren, 1989.

Bausenhardt, Werner. German Immigration and Assimilation in ontario, 1783-1918. Toronto: Legas, 1989. 
Bayor, Ronald $\mathrm{H}$. Neighbors in Conflict: The Irish, Germans, Jews, and Italians of New York Cjty, 1929-41.

Baltimore: Johns Hopkins University Press, 1978.

Bazillion, Richard J. Modernizing Germany: Karl

Biedermann's Career in the Kingdom of Saxony, 1835-1901. New York: Peter Lang, Inc., 1990.

Benscn, James K. Irish and German Families and the Economic Development of Mid-Western Cities, 1860-1895. New York: Garland Publishing, Inc., 1990.

Bedford New Hampsire, History of. Bedford, NH: Bedford Historical Association, 1972.

Bernard, Richard M. The Melting Pot at the Alter: Marital Assimilation in Early Twentieth-Century Wisconsin. Minneapolis: University of Minnesota Press, 1980.

Berquest, James M. "The Forty-eighters and the Politics of the 1850's." in Germany and America: Essays on Problems of International Relations and Immigration. ed. Hans $L$. Trefousse, 111-121. New York: Brooklyn College Press, 1980.

"German-America in the 1890's: Illusions and Realities." in Germans in America: Aspects of GermanAmerican Relations in the Nineteenth Century. ed. E. Allen McCormick, 1-14. New York: Columbia University Press, 1983.

- "German Communities in American Cities: An Interpretation of the Nineteenth-Century Experience." Tournal of American Ethnic History. 4 (Fall 1981): 9-30.

Bennett, David H. Demagoques in the Depression: American Radicals and the Union Party, 1932-1936. New Brunswick: Rutgers University Press, 1969.

Billigmeier, Robert Henry: Americans from Germany: A Study in Cultural Diversity. Belmont, CA: Wadsworth Publishing, 1974 .

Blood, Grace Holbrook. Manchester on the Merrimack: The

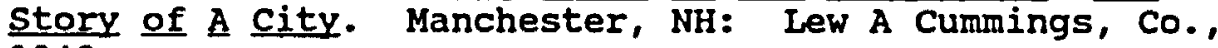
1948 .

Bodnar, John. Immigration and Industrialization: Ethnicity in an American Mill Town, 1870-1940. Pittsburgh: University of Pittsburgh Press, 1977. 
"Immigration, Kinship, and the Rise of Workingclass Realism in Industrial America." Journal of Social History. 14 (Fall 1980): 45-65.

- The Transplanted: A History of Immigrants in Urban America. Bloomington: Indiana University Press, 1985.

- Workers' World: Kinship, Community, and protest in an Industrial Society, 1900-1940. Baltimore: Johns Hopkins University Press, 1982.

Brantz, Rennie $W$. "German-American Friendship: The Carl Schurz Vereinigung, 1926-1942." The International History Review. Il (May 1989): 229-251.

Bretting, Agnes. "Little Germanies in the United States." in Germans to America: 300 Years of Immigration, 16831983. ed. Günter Moltman, 144-151. Stuttgart: Institute for Foreign Cultural Relations, 1982.

"Ihe OId fome and the ifew: The problem of Americanization." in Germans to America: 300 years of Immigration, 1683-1983. ed. Gunter Moltman, 152-159. Stuttgart: Institute for Foreign Cultural Relations, 1982 .

- Soziale Probleme deutscher Einwanderer in New York City, 1830-1860. Wiesbaden: Franz steiner verlag, 1981 .

Bretting Agnes, and Hartmut Bickelmann. "Auswanderungsagentum und Auswanderunsgvereine im 19. und 20. Jahrhundert." in Von Deutschland nach Amerika: zur Sozialgeschichte der Auswanderung im 19. und 20. Jahrhundert. ed. Günter Moltmann, Band 4. Stuttgart: Franz Steiner Verlag, 1991.

Bridges, Amy. "Becoming American: The Working classes in the United States Before the Civil War." in Workingclass Formation: Nineteenth-Century Patterns in Western Europe and the United States. eds. Ira Katznelson and Arstide R. Zolberg, 157-196. Princeton: Princeton University Press, 1986.

Brinkley, Alan. Voices of Protest: Huey Long, Father Coughlin, and the Great Denression. New York: Alfred Knopf, 1982 .

Buenker, John D, and Nicholas Bruckel. Immigration and Ethnicity: A Guide to Information and Sources. Detroit: Gale Research Co, 1977. 
Burnes, Kenneth c. "The Missouri Synod and Hitler's Germany." Yearbook of German-American Studies. 24 (1987): $131-148$.

Burstein, Alan N. "Immigrants and Residential Mobility: The Irish and Germans in Philadelphia, 1850-1880," in Philadelphia: Work, Space, and Group Experience in the Nineteenth Century. ed. Theodore Hershberg, 174-203. New York: Oxford University Press, 1981.

Cahn, William. Lawrence 1912: The Bread and Roses Strike. New York: Pilgrim Press, 1977.

- Mill Town. New York: Cameron \& Kahn, 1954.

Canedy, Susan. America's Nazis, A Democratic Dilemma: A History of the German American Bund. Menlo Park, CA; Markgraf Publication Group, 1990.

Cameron, Ardis. "Bread and Roses revisited: Women's culture and working-class activism in the Lawrence strike of 1912." in Women, Work, and Protest: A Century of U.S. Homen's Labor History. ed. Puth Milkman, 42-61. Boston: Routledge and Kegan, 1985.

Radicals of the Worst Sort: Laboring women in Lawrence, Massachusetts, 1860-1917. Urbana: University of Illinois Press, 1993

Canning, Kathleen "Gender and the Politics of class Formation: Rethinking German Labor History." The American Historical Review. 96 (June 1992): 736-768.

Cash, Kevin. Who the Hell is William Loeb? Manchester, NH: Amoskeag Press, 1975.

Cecil, Lamar. Wilhelm II: Prince and Emperor, 1859-1900. Chapel Hill, University of North Carolina Press, 1986.

Child, Clifton James. The German Americans in Politics, 1914-1917. New York: Arno Press, 1970. TOriginally published 1939).

Chmelar, Johan. Trans by Thomas c. Childers "The Austrian Emigration, 1900-1914." Perspectives in American History; Dislocation and Emiaration, The Social Background of Ammerican Immigration. III, 1973, 275-378.

Clark, Dennis. Erin's Heirs: Irish Bonds of Community. Lexington, KY: The University of Lexington Press, 1991. 
Hibernia America: The Irish and Regional

Cultures. New York: Greenwood Press, 1986.

Cohen, Naomi w. Encounter with Emancipation: The German Jews in the United States, 1830-1914. Philadelphia: The Jewish Publications of Americaa, 1984.

Cole, Arthur Harrison, The American Wool Manufacture. Cambridge: Harvard University Press, 1926, 2 vols.

Cole, Donald B. Immigrant City: Lawerence Massachusetts, 1845-1921. Chapel Hill: University of North Carolina Press, 1963.

Commager, Henry Steele, ed. Immigration and American History. Minneapolis: University of Minnesota Press, 1961.

Conzen, Kathleen Neils. "Die deutsche Amerikaeinwanderung im landlichen Kontext: Problemfelder und

Forschungsergebnisse." in Auswanderer-WanderarbeiterGastarbeiter: Bevblkerung, Arbeitsmarkt, und Wanderung in Deutschland seit der Mitte des 19 Jarhunderts. ed. Klaus J Bade, 350-377. Ostfildern: Scripta Mercature, Verlag, 1984 .

- "German-Americans and the Invention of Ethnicity" in American and the Germans: An Assessment of a Three Hundred Year History. eds. Frank Trommler and Joseph MCVEigi, Vol I, 131-147. Philadelphia: University of Pennsylvania Press, 1985.

- "Germans." in Harvard Encyclopedia of American

Ethnic Groups. ed. Stephan Thernstrom, 405-425.

Cambridge: Harvard University Press, 1980.

- "Immigrants, Immigrant Neighborhoods, and Ethnic Identity: Historic Issues." The Journal of American History. 66 (December 1979): 603-615.

- Immigrant Milwaukee, 1836-1860: Accomodation and Community in a Frontier City. Cambridge: Harvard University Press, 1976.

\footnotetext{
- "Making their Own America: Assimilation Theory and the German Peasant Pioneer." Annual Lecture, number 3 of the German Historical Institute, Washington, D.C. New York: Berg Publishers, 1990.

- "The Paradox of German-American Assimilation." Yearbook of German-American Studies. 16 (1981): 153-60.
} 
"The Writing of German-American History." The Immigration History Newsletter. 12 (November 1980): 1-14.

Copeland, Melvin Thomas. The Cotton Manufacturing Industry of the United States. New York: Augustus M. Kelly, 1977 .

Corry, Mary Jane. "The Role of German Singing Societies in Nineteenth-Century America." in Germans in America: Aspects of German-American Relations in the Nineteenth Century. ed. E. Allen McCormick, 155-168. New York: Columbia University Press, 1983.

Cuddy, Edward. "Pro-Germanism and American Catholicism, 1914-1917. The Catholic Historical Review. 54 (October 1968): $427-454$.

Cumbler, John T. "The city and community: The Impact of Urban Forces on Working Class Behavior." Iournal of Urban History. 3 (August 1977): 427-442.

Cunz, Dieter. A History of the Germania Club, 1840-1940. Baltimore, MD: The Society for the History of Germans in Maryland, 1940.

- The Maryland Germans: A History. Princeton, NJ: Princeton University Press, 1948 .

Curran, Alfred A. German Immigration to Pennsylvania: 16831933. Columbus, GA: Brentwood University Press, 1986.

Curti, Merle, The Roots of American Loyalty. New York: Antheneum, 1968 .

Daniels, Roger: Coming to America: A History of Immigration and Ethnicity in American Life. New York: Harper Colliers Pub, 1990.

Dasey, Robyn. "Women's Work and Family: Women Garment Workers in Berlin and Hamburg Before the First World War." in The German Family: Essays on the Social History of the Family in Nineteenth and Twentieth Century Germany. eds. Richard J. Evans and W. R. Lee, 221-255. London: Croom Helm, 1981.

Dashefsky, Arnold and Howard Shapiro. Ethnic Identification Among American Jews. Lexington, MA: Lexington Books, 1974.

Dawley, Alan. class and Community: The Industrial Revolution in Lynn. Cambridge: Harvard University Press, 1976 . 
Dawson, Andrew. "The Parameters of Craft Consciousness: Social outlook of the Skilled worker, 1890-1920." in American Labor and Immigration, 1877-1920: Recent European Research. ed. Dirk Hoerder, 135-155. Urbana: University of Illinois Press, 1983.

Detjen, David w. The Germans in Missouri, 1900-1918: Prohibition, Neutrality, and Assimilation. Colombia, MO: University of Missouri Press, 1985.

Diamond, Sander. "The Bund Movement in the United States: An Overview." in Germany and America: Essays on Problems of International Relations and Inmigration. ed. Hans L. Trefousse, 183-198. New York: Brooklyn College Press, 1980.

- The Nazi Movement in the United states, 1924-1941. Ithaca: Cornell University Press, 1974.

Dick, Harold G. with Douglas H. Robinson. The Golden Age of the Great Passenger Airship: Graf Zeppelin and Hindenberg. Washington: Smithsonian Institute Press, 1985.

Dinnerstein, Leonard, and Roger L. Nichols. Natives and Strangers: Blacks, Indians, and Immigrants in America. 2nd ed. New York: Oxford University Press, 1990.

, and David M. Reimers. Ethnic Americans: A History of Immigration and Assimilation. New York: Harper and Row, 1975.

Dippel, Horst. "German Emigrants to Genesee County in 1792: An Episode in German-American Migration." in Germany and America: Essays on Problems of International

Relations and Immigration. ed. Hans I. Trefousse, 161170. New York, Brooklyn College Press, 1980.

Dobbert, Guido A. "German-Americans between New and old Fatherland, 1870-1914." American Quarterly.

19 (Winter 1967): 663-680.

- The Disintegration of an Immigrant Community: The Cincinnati Germans, 1870-1920. New York: Arno Press, 1980 .

Dobkowski, Michael N. "The Politics of Restrictionism: Anti-German Refugees Face a Cold World." in Germany and America: Essays on problems of International Relations and Immigration. ed. Hans $L$. Trefousse, 199-214. New York: Brooklyn College Press, 1980. 
Doenecke, Justus D. "Germany in Isolationsit Ideology, 193941: The issue of a Negotated Peace." in Germany and America: Essays on problems of International Relations and Immigration. ed. Hans L. Trefousse, 215-226. New York: Brooklyn College Press, 1980.

Dolan, Jay P. The Immigrant Church: New York's Irish and German Catholics, 1815-1865. Baltimore: The Johns Hopkins University Press, 1975.

Dolmetsch, Christopher. "Location of German Language Newspapers and Periodical Printing in the United states, 1732-1976." Monatshefte. 67 (Summer 1976): 188-193.

Dorset, Lyle w. "The ordeal of Colorado's Germans during world War I." Colorado Magazine. 54 (1974): 277-293.

Drummond, Andrew Landale. German Protestantism since Luther. London: Epworth Press, 1951.

Dublin, Thomas. Women at Work: Transformation of Work and Community in Lowell, Massachusetts, 1826-1860. New York: Columbia University Press, 1979.

Dunwell, Steve. The Run of the Mill: A Pictorial Narrative of the Expansion, Domination, Decline, and Enduring Impact of the New Enqland Textile Industry. Boston: David R Godine, 1979.

Durden, William G. "Nineteenth-Century German-American Reading Societies: An Alternative Educative Institution." in Germans in America: Aspects of GermanAmerican Relations in the Nineteenth Century. ed. E. Allen McCormick, 47-58. New York: Columbia University Press, 1983.

Economides, Stephen. Der National-Sozialismus und die deutschsprachige Presse, 1933-41. Frankfurt a. M.: Peter Lang, 1982.

Eichoff, Jürgen. "The German Language in America." in American and the Germans: An Assessment of a Three Hundred Year History. eds. Frank Trommler and Joseph NcVeigh, Vol I, 223-240. Philadelphia: University of Pennsylvania Press, 1985.

Eldredge, H. Wentworth. "Enemy Aliens: New Haven Germans During the World War." in studies in the science of Society. ed. George Peter Murdock, 202-224. Freeport, NY: Books for Libraries Press, 1969, (c. 1937).

Ellerkamp, Marlene. Industriearbeit, Krankheit, und Geschlecht: zu den Sozialen Kosten der 
Industrialisierung Bremer Textilarbeiterinen, 18701914. G8ttingen: Vanderhoeck \& Ruprecht, 1991.

"Emigration: A Franco-American Experience." ovo Magazine. 12 (1982).

Ensslen, Klaus. "German-American Working class Saloons in Chicago: Their Social Function in an Ethnic and class specific cultural Context." in German Worker's Culture in the Unites States, 1850-1920. ed. Hartmut Keil, 157-188. Washington: Smithsonian Institution Press, 1988 .

Ensslen, Klaus, and Heinz Ickstadt. "German Working class Culture in Chicago: Continuity and Change in the Decade from 1900 to 1910." in German Workers in Industrial Chicago, 1850-1910: A comparative Perspective. eds Hartmut Keil and John B. Jentz, 236-252. DeKalb, Ill: Northern Illinois Unversity Press, 1983.

Erickson, Charlotte. American Industry and European Immigration, 1860-1885. New York: Russell and Russell, 1967.

Esslinger, Dean R. "American German and Irish Attitudes Toward Neutrality, 1914-1917: A Study in Catholic Minorities." The Catholic Historical Review. 53 (July 1967): $194-216$.

- "Immigration Through the Port of Baltimore," in Forqotten Doors: The other Ports of Entry to the United States. ed. M. Mark stolark, 61-74. Philadelphia: The Balch Institute Press, 1988.

Faires, Nora. "Ethnicity in Evolution: The German Community in Pittsburgh and Allegheny City, Pennsylvania, 18451885." PhD Diss., University of Pittsburgh, 198:.

- "Occupational Patterns of German-Americans in Nineteenth-Century American Cities." in German Workers in Industrial Chicago, 1850-1910: A Comparative Perspective. eds. Hartmut Keil and John B. Jentz, 37-51. DeKalb, Ill: Northern Illinois Unversity Press, 1983 .

Fenske, Hans. "International Migration: Germany in the Eighteenth Century. Central European History.

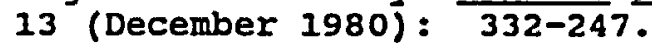

Fishman, Joshua A. "Ianguage Maintenance." in Harvard Encyclopedia of American Ethnic Groups. ed. Stephen Thernstrom, 629-638. Cambridge: Harvard University Press, 1980. 
Fleming, Donald, and Bernard Bailyn. The Intellectual Migration: Europe and America, 1930-1960. Cambridge: Harvard University Press, 1969.

Flynn, Elizabeth Curley. "The Lawrence Textile Strike," in America's Working Women: A Documentary History 1600 to Present, comp. and ed. Rosalyn Baxandall, Linda Gordon, and Susan Reversby, 194-200. New York: Vintage Books, 1976.

Forberger, Rudolf. Die Industrielle Revolution in Sachsen. 1800-1861. Berlin: Akademie verlag, 1982, 2 vols.

Foster, Walter 0 . zion on the Mississippi: The Settlement of the Saxon Lutherans in Missouri, 1839-1841. St. Louis: Concordia Publishing House, 1953.

Freidel, Frank. Francis Lieber: Nineteenth Century Liberal. Glouseter, MA: Peter Smith, 1968. (reprint of 1947 issue).

Friesen, Gerhard, and Walter schatzberg, eds. The German Contributions to Building of the Americas. Worcester, MA: Clark University Press, 1977.

Frye, Alton. Nazi Germany and the Amoxiran Hemisphere. Now Haven: Yale University press, 1967.

Fuchs, Lawrence. "Immigration Through the Port of Boston." in Forgotten Doors: The other Ports of Entry to the United States. ed. I. llark stolark, 26-35.

Philadelphia: The Balch Institute Press, 1988.

Furer, Howard B. ed. The Germans in America, 1607-1970: A Chronology and Fact Book. Dobbs Ferry, NY: Ocenea Publishing, Inc., 1973.

Gans, Herbert J. The Urban Villagers: Group and class in the Italian-Americans. New York: The Free Press, 1982.

Garbe, Otfried. "Fredrich List: His Impact on the Economic Indepencence of the United States." in Germany and America: Essays on Problems of International Relations and Immigration. ed. Hans L. Trefousse, 151-160. New York: Brooklyn College Press, 1980.

Gatzke, Hans $w$. Germany and the United States: A Special Relationship. Cambridge, MA: Harvard University Press, 1980. 
Geiss, Imanuel. German Foreign Policy, 1871-1914. London and Boston: Routledge and Kegen Paul, 1976.

Geitz, Henry, ed. The German-American Press. Madison: University of Wisconsin, Max Kade Institute for GermanAmerican Studies, 1992.

Gerber, David A. "Language Maintenance, Ethnic Group Formation and Public Schools: Changing Patterns of German Concern, Buffalo, 1837-1874," Journal of American Ethnic History. 4 (Fali 1984): 31-61.

Gitelman, Howard M. Workingmen of Waltham: Mobility in American Urban Industrial pevelopment, $1850-1890$. Baltimore, The Johns Hopkins University Press, 1974.

Glasco, Lawerence A. Ethnicity and Social Structure: Irish, Germans, and Native Born of Buffalo, New York, 18501860. New York: Arno Press, 1980 .

Glazer, Nathan. "Beyond the Melting Pot, Twenty Years After." Journal of American Ethnic History. 1 (Fall 1981), 43-55.

"The Process and Problems of Language-

Maintenance: An Integrative Review." in Lanquage

Loyalities in the United States: The Maintenance and Perpetuation of Non-English Mother Tongues by American Ethnic and Religious Groups. ed. Joshua A. Fishman, 358368. The Hague: Mouton and Co., 1966.

Glazer, Nathan, and Daniel Patrick Moynihan. Beyond the Melting pot. Cambridge, MA: M.I.T Press and Harvard University Press, 2nd. ed., 1964.

Gleason, Philip, "American Identity and Americanization." in Dimensions of Ethnicity. ed. Stephen Thernstrom, 57-143. Cambridge: Harvard University Press, 1982.

"The Central Verein, 1900-1917: A Chapter in the History of German-American Catholics." PhD Diss., University of Notre Dame, 1960.

- The Conservative Reformers: German-American Catholics and the Social order. South Bend, IN: University of Notre Dame Press, 1968.

Goethe Society of New England. Germans in Boston. Boston: 1981

Gordon, Milton M. "Assimilation in America: Theory and Reality." Daedalus. 90 (1961): 263-285. 
Assimilation in American life: The Roll of Race, Religion, and National origins. New york: oxford University Press, 1964 .

Green, Constance McLaughlin. Holyoke Massachusetts: A Case History of the Industrial Revolution in America. Boston: Archon Books, 1968.

Greenberg, Stephanie. "Industrial Location and Ethnic Residential Patterns in an Industralizing City:

Philadelphia." in Philadelphia: Work, Space, and Group Experience in the Nineteenth Century. eds. Theodore Herschberg, et. al. 204-232. New York: oxford University Press, 1981.

Greene Victor R. American Immigrant Leaders, 1800-1910: Marginality and Identity. Baltimore: Johns Hopkins University Press, 1987.

Griffen, Clyde, and Sally Griffin. Natives and Newcomers: The ordering of opportunity in Mid-Nineteenth Century Poughkeepsie. Cambridge: Harvard University Press, 1970 .

Hagedorn, Hermann. The Hyphenated Family: An American Saga. New York: Macmillan, 1960.

Hamerow, Theodore S. Restoration, Revolution, Reaction: Econcmics and politics in Germany, 1815-1871. Princeton: Princeton University Press, 1967.

Handlin, Oscar. Boston's Immigrants: A Study in Acculturation. Cambridge: Harvard University Press, 1959, (c. 1941).

- "Historical Perspectives on the American Ethnic Group." Daedalus 90 (1961): 220-232.

- Immigration as a Factor in American History. Englewood Cliffs, N. J.: Prentice-Hall, 1965. 195i).

Uprooted. Boston: Little, Brown, 1373, (c.

Hanlan, James P. The Working Population of Manchester, New Hampshire, 1840-1886. Ann Arbour: University of Michigan Press, 1990.

Hannemann, Max. "Das Deutschtum in Den Vereinigten staaten: Seine Verbreitung und Entwicklung site der Mitte des 19 Jahrhundrets." in A. Petermanns Mitteilungen aus Justus Perthes, Geographischer Anstalt. 49 (1936): $\frac{1-75}{5}$ 
Hansen, Marcus Lee. The Atlantic Migration, 1607-1860: A History of the continuing Settlement of the United

states. Cambridge: Harvard University Press, 1940.

- German Schemes of Colonization Before 1860 .

Northampton, MA: Smith College Press, 1924.

- The Immigrant in American History. Cambridge:

Harvard University Press, 1942.

- The Mingling of the Canadian and American Peoples. New York: Arno Press, 1970.

"The Third Generation in America." Comentary.

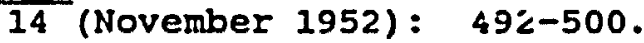

Harrington, Mona, "Loyalties: Dual and Divided." in Harvard Encyclopedia of American Ethnic Groups. ed. Stephen Thernstrom, 676-686. Cambridge: Harvard University Press, 1980.

Hartford, William $F$. Working Peonle of Holyoke: Class and Ethnicity in a Massachusets Mill Town 1850-1960. New Brunswick: Rutgers University Press, 1990.

Hareven, Tamara K. Family Time and Industrial Time: The Relationship between the Family and Work in a New England Industrial community. Interdisciplinary Perspectives on Modern History. Cambridge: Cambridge University Press, 1982.

"The Laborers of Manchester, New Hampshire: The Role of Family and Ethnicity in Adjustment to Industrial Life." Labor History. 16 (Spring 1978): 249-265.

Hareven, Tamara K. and Lagenbach Randolph. Amoskeag: Life and Work in an American Factory-City. New York: Pathenon Books, 1978.

Harzig, Christine. "Chicago's German North Side, 1880-1900: The Structure of a Gilded Age Ethnic Neighborhood." in German Workers in Industrial Chicago, 1850-1910: A Comparative Perspective. eds. Hartmut Keil and John B. Jentz, 127-141. DeKalb, III: Northern Illinois Unversity Press, 1983.

- "The Role of German Women in the German-American Working class Movement in Late Nineteenth-Centur $F_{Y}$ New York.: Journal of American Ethnic History. 8 (Spring 1987): 87-107.

Hauptmann, Gerhart. The Weavers: A Drama of the Forties. Trans. Mary Morrison. New York: B.W. Huebsch, 1911. 
Hawgood, John A. The Tragedy of German America. New York: Arno Press, 1970, (c. 1940).

Hayden, Robert G. "Some Community Dynamics of LanguageMaintenance." in Language Loyalities in the United States: The Maintenance and Perpetuation of Non-English Mother Tonques by American Ethnic and Religious Groups. ed. Joshua A. Fishman, i90-205. The Hague: Mouton and Co. , 1966.

Heiss, Christine. "Popular and Working-class German Theater in Chicago, 1870-1910." in German Workers' Culture in the United States, 1850-1920. ed. Hartmut Keil, 181202. Washington: Smithsonian Institution Press, 1988.

Helbich, Wolfgang. "The Letters They Sent Home: Subjective Perspectives of German-American Immigrants in the Nineteenth-Century." Yearbook of German-American studies. 22 (1987): 1-20.

Helbich, Wolfgang, Walter D. Kamphoefner, and Ulrike Sommer, eds. Briefe aus Amerika: Deutsche Auswanderer Schreiben aus der neuen Welt, 1830-1930. München: Verlag C.H. Beck, 1988.

Herbst, Jurgen. The German Historical School in America: A Study in the Transfer of Culture. Ithaca: Cornell Univeristy Press, 1965.

Herberg, Will. Protestant--Catholic--Jew: An Essay in Religious sociology. Garden City, NY: Doubleday \& Co., Inc., 1955.

Hershberg, Theodore, Alan N. Burstein, Eugene P. Erickson, Stephanie W. Greenberg, and William Yancy. "A Tale of Three Cities: Black, Immigrants, and opportunity in Philadelphia, 1850-1880, 1930, 1970. in Philadelphia: Work, Space, and Group Experience in the Nineteenth Century. eds. Theodore Hershberg, et. al. 461-491. New York: oxford University Press, 1981.

Higham, John. "Current Trends in the Study of Ethnicity in the United States." Journal of American Ethnic History. 2 (Fall 1982): 5-15.

- Integrating America: The Frobiem of issimilation in the Nineteenth Century." Journal of American Ethnic History. 1 (Fall 1981): 7-25.

- Send These to Me: Immigrant in Urban America. Baltimore: Johns Hopkins Press, 1984. 
Strangers in the Land: Patterns of American Nativism, 1860-1925. New Brunswick: Rutgers University Press, 2nd ed. 1988.

Hoerder, Dirk. "Akkulturationsprobleme in den USA: 'Neue Immigration' zwischen Einwanderung und Arbeitsmigration." in Auswanderer-WanderarbeiterGastarbeiter: Bevilkerung, Arbeitsmarkt, und Wanderung in Deutschland seit der Mitte des 19 Jarhunderts. ed. Klaus J. Bade, 406-428. Ostfildern: Scripta Mercature, Verlag, 1984. on the "American Labor and Immigration History: Report European Countries." Labor History. Part I, 21 (Spring 1980): 261-276; Part II, 21 (Summer 1980): 392-419.

- ed. American Labor and Immigration, 1877-1920: Recent European Research. Urbana: University of Illinois Press, 1983.

- "The Traffic of Emigration via Bremen/Bremerhaven: Merchants' Interests, Protective Legislation, and Migrants' Experiences." Journal of American Ethnic History. 13 (Fall 1993): 68-101.

- "Why Did You Come?" The proletarian Mass Migration Project, 1980-1985. Bremen: Universitat Bremen, 1986.

Hofmann, John E. "Mother Tongue Retentativeness in Ethnic Parishes." in Lanquage Loyalities in the United States: The Maintenance and Perpetuation of Non-English Mother Tonques by American Ethnic and Reliqious Groups. ed. Joshua A. Fishman, 127-155. The Hague: Mouton and Co., 1966.

Holli, Melvin G. "Teuton vs Slav: The Great war Sinks Chicago's German Kultur." Ethnicity. 8 (December 1981): 406-451.

Holly, H. Hobart. "Some Germans of Germantown in Massachusetts." New England Historical and Genealogical Register. 138 (JulY 1984): 227-230.

Ilolmes, Douglas R. and Jean H. Quatāert. "àn approach to Modern Labor: Worker Peasantries in Historic Saxony and the Fruili Region over Three Centuries. Comparitive studies in society and History. 28 (Apri1 1986): 191-216.

Howe, Irving. Norld ef our Eathers. Hew York: Harcourt, 1976. 
Huffines, Marion L. "Language Maintenance Efforts among German Immigrants and their Descendents in the United states." in America and the Germans: An Assessment of a Three Hundred Year History. eds. Frank Trommler and Joseph McVeigh, Vol I, 241-250. Philadelphia: University of Pennsylvania Press, 1985.

Hutchinson, E.P. Immiarants and their Children, 1850-1950. New York: John Wiley \& Sons, 1956.

Jackson, Kenneth T. Crabgrass Frontier: The Suburbanization of the United States. New York: Oxford University Press, 1985.

Jantz, Harold S. "German Thought and Literature in New England, 1620-1820." The Journal of English and Germanic Philology. 31 (January 1940): 1-45.

Jarausch, Konrad H. "Perceptions." The Wilson Quarterly. 5 (Summer 1981): 56-65.

Jentz, John B. "Artisan Culture and the organization of Chicago's German Workers in the Guilded Age, 1.860-1890." in German Worker's Culture in the United States, 18501920. ed. Hartmut Keil, 59-80. Washington: Smithsonian Institution Press, 1988.

Johnston, Paul I. "Freedom of Speech means Freedom to Teach: The Constitutional Battle in Nebraska, 1919-1923." Concordia Historical Institute Quarterly. 52 (1979): 118-124.

Jones, Maldwyn Allen. American Immigration. Chicago: University of Chicago, 1960.

Kamphoefner, Walter D. "At the Crossroads of Economic Development: Background Factors Affecting Emmigration from Nineteenth Century Germany." in Migrations Across Time and Nations: Population Mobility in Historical Contexts. eds. Ira Glazer and Luigi De Rosa, 174-201. New York: Holmes and Meier, 1986.

"'Entwurzelt oder Verpflanzt?' zur Bedeutung der Kellenwanderung für die Einwander-akulturation in Amerika." in Auswanierer-Wanderarbeiter-Gastarbeiter: Bevolkerung, Arbeitsmarkt, und Wanderung in Deutschland seit der Mitte des 19 Jarhunderts. ed. Klaus J. Bade, 221-271. Ostfildern: Scripta Mercature Verlag, 1984.

"preissiger and Forty-eighter: The Political Influence of Two Generations of German Political Exiles." in Germany and America; Essays on problems of International Relations and Immiaration. ed. Hans L. 
Trefousse, 89-102. New York: Brooklyn College Press, 1980 .

The Westfalians from Germany to Missouri.

Princeton: Princeton University Press, 1987.

Kamphoefner, Walter D., Wolfgang Helbich, and Ulrike Sommer eds. News from the Land of Freedom: German Immiarants write Home. Ithaca, NY: Cornell University Press, 1991.

Katz, Michael B. The Irony of Early School Reform: Educational Innovation in Mid-Nineteenth Century Massachusetts. Cambridge: Harvard University Press, 1968 .

Katznelson, Ira and Arstide R. Zolberg, eds. Working-class Formation: Nineteenth Century patterns in Western Europe and the United states. Princeton: Princeton University Press, 1986.

Keller, Phyllis. States of Belonging: German American Intellectuals and the First World war. Cambridge: Harvard University Press, 1977.

Keil, Hartmut. "Chicago's German Working Class in 1900." in German Workers in Industrial Chicago, 1850-1910: A Comparative Perspective. eds. Hartmut Keil and John B. Jentz, 19-36. DeKalb, Ill: Northern Illinois Unversity Press, 1983.

- "Die deutsche Amerikaeinwanderung in StHdtischindustrielien Kontext: das Biespiel Chicago, 18801910 in Auswanderer-Wanderarbeiter-Gastarbeiter: Bevolkerung, Arbeitsmarkt, und Wanderung in Deutschland seit der Mitte des 19 Jarhunderts. ed. Klaus J. Bade, 378-405. Ostfildern: Scripta Mercature, Verlag, 1984.

"German Imnigrant Workers in Nineteenth-Century America: Working-class culture and Everyday life in an Urban Industrial Setting." in American and the Germans: An Assessment of a Three Hundred Year History. eds. Frank Trommler and Joseph McVeigh, Vol I, 189-206. Philadelphia: University of Pennsylvania Press, 1985.

"The German Immigrant Working Class of Chicago, in American Labor and Immigration: Recent European Research. ed. Dirk Hoerder, 156-176. Urbana: University of Illinois Press, 1983.

- "Immigrant Neighborhoods and American Society: German Immigrants on Chicago's Northwest side in the 
Late Nineteenth Century." in German Workers' Culture in the Unites States, 1850-1920. ed. Hartmut Keil, 25-58. Washington: Smithsonian Institution Press, 1988.

Keil, Hartmut, and Heinz Ickstadt. "Elements of German Working-class Culture in Chicago, 1880-1890." in German Worker's Culture in the United States, 1850-1920. ed. Hartmut Keil, 81-108. Washington: Smithsonian Institution Press, 1988.

Keil, Hartmut, and John B. Jentz, eds. German Workers in Chicago: A Documentary History of Working-Class Culture from 1850 to World War I. Chicago: University of Illinois Press, 1988.

Keil, Hartmut, and John B. Jentz, eds. German Workers in Industrial Chicago, 1850-1910: A comparative Perspective. Dekalb, IIIinois, Northern Illinois University Press, 1983.

Kellenbenz, Hermann. Deutsche Wirtschaftsgeschite: Von Ausgang 18. Jahrhunderts bis zum Ende des zweiten Weltkriegs. Band II. München: verlag C. H. Beck, 1981.

Kennedy, David M. Over Here: The First World War and American Society. New York: Oxford University Press, 1980 .

Kennedy, Ruby Jo Reves. "Single or Triple Melting Pot: Intermarriage in New Haven, 1870-1950." American Journal of Sociology. 58 (July 1952): 56-59.

Kereztesi, Michael, and Garr R Cocozzuli. German-American History and Life: A Guide to Information Sources. Detroit: Gale Research, 1980.

Kiesewetter, Hubert. Industrialisierung und Landwirtschaft: Sachsens stellung im regionalen Industrialisierungsprozess Deutschlands im 19. Jahrhundert. KUIn: Bblau Verlag, 1988 .

Kirschbaum, Erik. The Eradication of German culture in the United States, 1917-1918. Stuttgart: Akademischer Verlag stuttgart, 1986.

Kiusto, Peter, and Dag Blancek, eds. American Immigrants and their Generations: Studies and consequences on the Hansen Thesis After Fifty Years. Chicago: University of Illinois Press, 1990.

Kloss, Heinz. "German-American Language Maintenance Efforts." ir Ianguage Loyalities in the United States: 
Maintenance and Perpetuation of Non-English Mother Tonques by American Ethnic and Religious Groups. ed. Joshua A. Fishman, 206-252. The Hague: Mouton and Co., 1966.

- The American Bilingual Tradition. Rowley, MA.: Newbury House Publishers, Inc., 1977.

- "Sander A Diamond's Surrealistic Portrayal of Research Done in the Third Reich on German Americans." Journal of German American Studies. 12 (Fall 1977): 47-72.

Kocka, Jürgen. "Problems of Working-class Formation in Germany: The Early Years, 1800-1875." in Working class Formation: Nineteenth-Century Patterns in Europe and the Unites states. eds. Ira Katznelson and Arstide R. zolberg, 279-351. Princeton: Princeton University Press, 2986.

K\&llmann, Wolfgang, and Peter Marschalck. "German Emigration to the United States." in Perspectives in American History: Dislocation and Emigration, the social Background of American Immigration. VII (1973): 499-534.

Kondert, Reinhardt. From Gleilenkirchen to Acadia Parish: A History of the Germans of Roberts Cove, 1880-1987.

Lafayette, Lousianna: University of Southwestern Louisianna Press, 1988.

Korman Gerd. Industrialization, Immigrants, and Americanizers: The View from Milwaukee, 1866-1921. Madison: The state Historical Society of Wisconsin, 1967.

Lamphere, Louise. From Working Daughters to Working Mothers: Immigrant woman in a New England Industrial Community. Ithaca: Cornell University Press, 1987.

Landes, David 5 . The Unbound Prometheus: Industrial Developmert in western Europe from 1750 to the present. London: Cambridge University Press, 1969.

Lang, Barbara. The Process of Immigration in German-American Literature from 1850 to 1900: A Change in Ethnic SelfDefinition. München": Wilhelm Fink Verlag, 1988.

Laurie, Bruce, Theodore Hershberg, and George Altar. "Immigrants and Industry: The Philadelphia Experience, 1850-1880." Philadelphia: Work, Space, and Group Experience in the Nineteerith Century. New York: Oxford University Press, 1981, 93-120. 
Layer, Robert G. Earnings of Cotton Mill operatives, 18251914. Cambridge, MA: Harvard University Press, 1955.

LeBlanc, Robert G. "The French-American Elite and the Conscription Crisis in Canada, 1916-1818." Unpublished paper, 1992. To appear as "The Franco-American Response to the Conscription Crisis in Canada, 1916-1918." American Review of Canadian studies. (Autumn 1993): 343-372.

Lemaire, Herve-B. "Franco-American Efforts on Behalf of the French Language in New England." in Lanquage Loyalities in the United States: Maintenance and Perpetuation of Non-English Mother Tonques by American Ethnic and Religious Groups. ed. Joshua A. Fishman, 252-279. The Hague: Mouton and Co., 1966.

Leonard, Stephen J. "The Irish, English, and Germans in Denver, 1860-1890." Colorado Magazine. 54 (1977): 126-153.

Levine, Bruce. The Spirit of 1848: German Immigrants, Labor Conflict, and the coming of the civil war. Chicago: University of Illinois Press, 1992 .

Levy, Alan Howard. "The American Symphony at War: GermanAmerican Musicians During World War I." Mid America. 71 (January 1989): 5-13.

Lieberson, stalney. Ethnic patterns in American cities. New York: Free Press of Glencoe, 1963.

Lieberson Stanley, and Mary c. Waters. From Many strands: Ethnic and Racial Groups in Conemporary America. New York: Russell Sage Foundation, 1988.

Link, Arthur S. Woodrow Wilson and the Progressive Era, 1910-1917. New York: Harper Torchbooks, 1963.

Logsdon, Jospeph. "Immigration Through The Port of New orleans." in Forgotten Doors: The other Ports of Entry to the United States. ed. M. Mark Stolark, 125-142. Philadelphia: The Balch Institute Press, 1988.

Luebke, David. "German Exodus: Historical Perspectives on the Nineteenth Century Emigration." Yearbook of GermanAmerican studies. 20 (1985): $1-10$.

Luebke, Frederick. "Alsatians." in Harvard Encyclopedia of American Ethnic Groups. ed. Stephan Thersntrom, 29-31. Cambridge: Harvard University Press, 1980. 
"Austrians." in Harvard Encyclopedia of American Ethnic Groups. ed. Stephan Thernstrom, 164-171. Cambridge: Harvard University Press, 1980.

- Bonds of Loyalty: German-Americans and World War I. DeKalb, II: North Illinois University Press, 1974 .

- Germans in Brazil: A Comparative History of Cultural Conflict During World War I. Baton Rouge: Louisiana State University Press, 1978.

- Germans in the New World: Essays in the History of Immiqration. Urbana: University of IIlinois Press, 1990 .

"Images of German Immigrants in the United States and Brazil, 1890-1918: Some Comparisons. in American and the Germans: An Assessment of a Three Hundred Year History. eds. Frank Trommler and Joseph McVeigh, Vol I, 207-220. Philadelphia: University of Pennsylvania press, 1985. "Immigrant Churches in Nebraska, 1889-1915."
Mid-America. 50 (1968): 116-130.

McCormick, E. Allen, ed. Germans in America: Aspects of German-American Relations in the Nineteenth Century. New York: Colubia University Press, 1983

McKeon, Valerie. "The Founding of St. Anselm: New Hampshire's First Catholic College." Historical New Hampshire. 41, (Spring and Summer 1986): 21-44.

Marschalck, Peter. Deutsche uberseewanderung im 19 Jarhundret: Ein Beitrad zur soziologischer Theorie der Bev81kerung. Stuttgart: Ernst klett Verlag, 1973.

Merrill, Peter c. "The Serial Novel in the German-American Press of the Nineteenth Century." Journal of German American Studies. 15 (1978): 16-22.

Metzner, Henry. History of the American Turners. National Council of the American Turners, Rochester, NY: 3rd. rev. ed. 1974 .

Miller, Frederick. "Immigration Through the Port of Philadelphia." in Forgotten Doors: The other Ports of Entry to the United States. ed. M. Mark Stolark, 55-60. Philadelphia: The Balch Institute Press, 1988.

Miller, Kerby. Immigrants and Exiles: Ireland and the Irish Exodus to North America. New York: Oxford University 
Press, 1985.

Miller, Marc Scott. The Irony of Victory: World War II and Lowell, Massachusetts. Urbana: University of IIlinois Press, 1988.

Mitchell, Brian C. The Paddy Camps: The Irish of Lowell, 1821-1861. Urbana: University of Chicago Press, 1988.

Molloy, Peter M. ed. The Lower Merrimack River Vallev: An Inventory of Historic Engineering and Industrial sites. North Andover, MA: Merrimack Valley Textile Museum, 1978.

Moltmann, Günter. "American-German Return Migration in the Nineteentin and Early Twentieth Centuries." Central European History. 13 (December 1980): 378-392.

- "German Emigration Overseas: History and Research Problems." Trans. George Weisenberg. German-Canadian Yearbook. 6 (1981): 5-15.

- "German Emigration to the United States during the First Half of the Nineteenth-Century as a Social Protest Movement." in Germany and America: Essays on problems of International Relations and Immigration. ed. Hans I. Trefousse, 103-110. New York: Brooklyn College Press, 1980 .

Morrison, Joan, and Zabusky, Charlotte Fox. imerican fiosaic: The Immigrant Experience in the Words of Those who Lived It. New York: E.P. Dutton, 1980 .

Nadel, stanley. Little Germany: Ethnicity, Religion, and Class in New York, 1845-80. Urbana: University of Illinois Press, 1990.

Nabriny, Vladimir C. and Joshua A. Fishman. "American Immigrant Groups: Ethnic Identification and the Problem of Generations." The Sociological Review (New Series). 13, (November 1965): 311-326.

Niebuhr, H. Richard. The Social Sources of Denominationalism. Cleveland and New York: Meridian Books, 1962.

Nolan, Mary. "Economic Crisis, State Policy and WorkingClass Formation in Germany, 1870-1900." in Working Class Formation: Nineteenth-Century Patterns in Western Europe and the United states. eds. Ira Katznelson and Arstide R. Zolberg, 352-396. Princeton: Princeton University Press, 1986. 
Novak, Michael. Further Reflections on Ethnicity. Middleton, PA: Jednota Press, 1977.

- "Pluralism in Humanistic Perspective." in Dimensions of Ethnicity. ed. Stephan Thernstrom, 27-56. Cambridge: Harvard University Press, 1982.

Nugent, Walter. Crossinas: The Great Transatlantic Migrations, 1870-1914. Bloomington, Indiana University Press, 1992.

O'Connor Richard. The German-Americans: An Informal History. Boston: Little, Brown and Company, 1968.

Oestreicher, Richard J. "Industrialization, Class and Compeiing Cuitural Systens: Detroit workers, 18751900." in Geman Workers in Industrial Chicago, 18501910: A Comparative Perspective. eds. Hartmut Keil and John B. Jent2, 52-72. DeKalb, Ill: Northern Illinois Unversity Press, 1983.

Olson, Audrey L. St. Louis Germans, 1850-1920: The Nature of an Immigrant Community and its Relation to the Assimilation Process. New York: Arno Press, 1980.

Parsons, William T. "The Pennsylfanisch Deitsch Community for Independence, 1758-1783." in Germany and America: Essays on Problems of International Relations and Immiaration. ed. Hans L. Trefousse, 72-88. New York: Brooklyn College 'rress, 1980.

Pedulla, Marianne. "Labor in a city of Immigrants: Holyoke, 1882-1888." Historical Journal of Massachusets. 13, (1985): 147-61.

Peterson, David. "From Bone Depth: German-American Communities in Rural Minnesota Before the Great War." Journal of American Ethnic History. 11 (Winter 1992): 27-55.

Peterson, Brent o. Popular Narratives and Ethnic Identity: Literature and Community in "Die Abendschule". Ithaca: Cornell University Press, 1991.

Peterson, William. "Concepts in Ethnicity." in Dimensions of Ethnicity. ed. Stephan Thersnstrom, 1-26. Cambridge: Harvard University Press, 1982.

Pierenkemper, Toni. "Die Vermarktung von Arbeitskraft in Deutschland: Begriff, Tendenzen, und Forschungsprobleme." in Auswanderer-Wanderarbeiter-Gastarbeiter:

Bevolkerung, Arbeitsmarkt, und wanderung in Deutschland 
seit der Mitte des 29 Jarhunderts. ed. Klaus J. Bade, 139-178. Ostfildern: Scripta Mercature, Verlag, 1984.

Piotrowski, Thaddeus M. A Bibliographical Index to

Manchester's (N.H) Ethnic Groups. Manchester, NH., 1977 .

- The German-American Heritage in Manchester, NH. Manchester, NH., 1978.

Pochman, Henry A. Bibliography of German Culture in America 1940. Madison: University of Wisconsin Press, 1953.

- German culture in America: Philosophical and Literary Influences. Madison: University of Wisconsin Press, 1957.

Poore, Carol. "Whose Celebration? The Centennial of 1876 and German-American Socialist Culture." in America and the Germans: An Assessment of a Three Hundred Year History. eds. Frank Trommler and Joseph McVeigh, Vol I, 176-188. Philadelphia: University of Pennsylvania Press, 1985.

Quataert, Jean H. "Combining Agragrian and Industrial Livelihood: Rural Households in the Saxon Oberlausitz in the Nineteenth Century." Journal of Family History. 10 (Summer 1985): 145-162.

- "The Politics of Rural Industrialization: Class, Gender, and collective Protest in the Saxon Oberlausitz of the iate Nineteenth Century." Central European History. 20 (June 1987): 91-124.

Rapone, Anita. The Gaurdian Life Insurance Company, 18601920: A History of a German-American Enterprise. New Yorik: New York University Press, 1987.

Ribuffo, Leo. "Fascists, Nazis and the Anerican Mind: Perceptions and Preconditions." American ouarterly. 76 (October 1974): 417-432.

Richter, Anton. "'Gibt ihr den Vorzug?' The German Language Press of North and South Dakota." South Dakota History. 10 (1980): 189-209.

Risch, Erna, "Joseph Crellius: Immigrant Broker." The New England Quarterterly, 12, (June 1939): 241-267.

Rischin, Moses, ed. Immiaration and the American Tradition. Indianapolis: Bobbs-Merrill Co., 1976. 
Rippley, LaVern. The German Americans. Boston: Twayne Publishing, 1976.

"German Assimilation: The Effect of the 1871 Victory on Americana-Germanica." in Germany and America: Essays on problems of International Relations and Immiaration. ed Hans L. Trefousse, 122-136. New York: Brooklyn College Press, 1980.

- "Germans from Russia." in Harvard Encyclopedia of American Ethnic Groups. ed. Stephan Thernstrom, 425430. Cambridge: Harvard University Press, 1980.

Rogers, Daniel T. The Work Ethic in Industrial America, 1850-1970. Chicago: University of Chicago Press, 1978.

Roggenbauer, Josef. "Uber die Schweren Anfunge einer deutschen Siedlung in New England aus der Mitte des 18 Jahrhunderts." Zeitschrift fur Kulturaustausch. 19 (Oktober-Dezember 1969): 297-330.

Rosenzweis, Roy. Eight Hours for What We Will: Workers and Leisure in an Industrial city, 1870-1920. Cambridge and New York: Cambridge University Press, 1985.

Rury, John. "Urban Structure and School Participation: Immigrant Women in 1900." Social Science History. 8 (1984): 212-241.

Schade, Gerhard R. The Germans and their Descendants in the Manchester New Hampshire Area. Manchester, NH: Private Printing, (no date given) approximately 1972.

Schelbert, Leo. "On Becoming an Emigrant: A Structural View of Eighteenth- and Nineteenth-Century Swiss Data." in Perspectives in American History: pislocation and Emigration, the Social Background of American Immigration. 7 (1973): 441-495.

"Swiss." in Harvard Encyclopedia of American Ethnic Groups. ed. Stephan Thernstrom, 981-987. Cambridge: Harvard University Press, 1980.

Schelbert, Leo. and Hedwig Rappolt. Alles ist ganz anders hier: Auswanderschicksale in Briefen aus zwei Jahrhunderten. Olten: Walter Verlag, 1977.

Schied, Fred M. Learning in Social context: Workers and Adult Education in Nineteenth century Chicago. De Kalb, IL: LEPS Press of Northern Illinois University, 1993.

Schlesinger, Jr. Arthur M. The Politics of Upheaval. Boston: Houghton Mifflin Co., 1960. 
Schlossmann, Steven L. "Is there an American Tradition of Bilingual Education? German in the Public Elementary Schools, 1840-1919." American Journal of Education. 91 (February 1983): 139-186.

Schbberl, Ingrid. Amexikanische Einwandererwerbung in Deutschland, 1845-1914. Stuttgart: Franz steiner Verlag, 1990.

- "Emigration Policy in Germany and Inumigration Policy in the United States." in Germans in America: 300 Years of Immigration, 1683-1983. ed. Günter Moltmann, 36-45. Stuttgart: Institute for Foreign Cultural Relations, 1982 .

Schroeder, Adolf E. and Carla Schultz-Geisberg, eds. Hold Dear as Always: Jette, a German Immigrant in Life and Letters. Columbia: University of Missouri Press, 1988.

Schneider, Dorothee. "'For Whom Are All the Good Things in Life?' German-American Housewives Discuss Their Budget." in German Workers in Industrial Chicago, 18501910: A Comparative Perspective. eds. Hartmut Keil and John B. Jentz, 145-162. DeKalb, Ill: Northern Illinois Unversity Press, 1983.

Scott, Clifford. "Assimilation in A German-American Community: The Impact of World War I." Northwest Ohio Quarterly. 52 (1980): 153-67.

Seller, Maxine. To Seek America: A History of Ethnic Life in the United States. New York: Jerome $S$. Ozer, Publsher, 1977.

Sheeton, James "Ethnicity and Immigration." in The New American History. ed. Eric Foner, 251-270. Philadelphia: Temple University Press, 1990.

Shore, Elliott, Ken Fones Wolf, and James $P$ Danky, eds. The German American Radical Press: The Shaping of a Left Political culture, 1850-1940. Urbana: University of Illinois Press, 1992.

Sickinger, Raymond and John Primeau. The Germans in Rhode Island: Pride and Perservance, 1850-1985. Providence: The Rhode Island Heritage Commission, 1985.

Sidon, Hans. I Chose America: The Story of an Immigrant Pastnr. New York: Vantage Press, 1978.

Silvia, Jr. Philip T. "The Position of Workers in a Textile Community: Fall River in the Early 1880's." Labor History. 16 (1975): 230-248. 
Smith, Jr. Arthur L. The Deutschtum of Nazi Germany and the Unites states. The Hague: Martinus Nijhoff, 1965.

"The Foreign Organization of the Nazi Party in the United States, 1931-1939." in Germany and America: Essays on problems of International Relations and Immigration. ed. Hans $L$. Trefousse, 173-182. New York: Brooklyn College Press, 1980.

Smith, Geoffrey s. To Save a Nation: The New Deal and the Coming of World War II. New York: Basic Books, Inc., 1973.

Smith, Timothy L. "Religion and Ethnicity in America." American Historical Review. 83 (December 1978), 1115-1185.

Solomon, Barbara Miller. Ancesters and Immigrants: A Changing New England Tradition. Cambridge: Harvard University Press, 1956.

Sowell, Thomas. Ethnic America: A History. New York: Basic Books, 1981.

Spuler, Richard. "American Germanistik and German Classicism: A Nineteenth-Century Exchange." in Germans in America: Aspects of German-American Relations in the Nineteenth century. ed. E. Allen McCormick, 59-78. New York: Columbia Univorsity Press, 1983.

Stack, John F, Jr. International Conflict in an American City: Boston's Irish, Italians and Jews, 1935-1944. Westport, CT: Greenwood Press, 1979.

Stolper, Gustav. The German Economy, 1870-Present. Trans Toni stolper. New York: Harcourt Brace \& World, 1967.

Swierenga, :obert P. "Dutch International Migration and Occupational Change: A Structural Analysis of Multinational Linked Files." in Migration Across Time and Nations: Population Mobility in Historical context. eds. Ira A. Glazer and Luigi De Rosa, 95-124. New York: Holmes and Meier: 1986.

"Exodus Netherlands, Promised Land America: Dutch Immigration and settlement in the United states." in $\underline{A}$ Bilateral Bicentennial: A History of Dutch-American Relations, 1782-1982. eds. J. W. Schulte Nordholt and Robert Swierenga. Amsterdam: Muelenhoff, 1932.

Taylor, Philip. The Distant Magnet: European Emigration to the USA. New York: Harper and Row, 1971. 
Thernstrom, stephan. The other Bostonians: Poverty and Progress in the American Metropolis, 1880-1970.

Cambridge: Harvard University Press, 1978.

- Poverty and progress: Social Mobility in a Nineteenth century City. Cambridge: Harvard University Press, 1964 .

- "lirbanization, Migration, and Social Mobility in Late Nineteenth-Century America." in Towards a New Past: Dissenting Essays in American History. ed. Barton J. Bernstein, 158-175. New York: Random House, 1968 .

Thernstrom, Stephan, and Richard Senrett, eds. Nineteenth Century cities: Essays in the New Urban History. New Haven: Yale University Press, 1969 .

Tipton, Frank B. Regional Variations in the Ecomomic Development of Germany During the Nineteenth Century. Middletown, CT. Wesleyn University Press, 1976.

Tischauser, Leslie V. The Burden of Etnnicity: The German Question in Chicago, 1914-1941. New York: Garland Publishing, 1990 .

Tolzmann, Don Heinrich. Cincinnati Germans After the Great War. New York: Peter Lang, 1987.

- "Frederick Jackson Turner's Frontier Thesis and the German-Americans." Heritage Review. 10, (1980): 15-21.

- German-Americana: A Bibliography. Metuchen, NJ: Scarecrow Press, Inc., 1975.

- comp. German American Literature. Metuchen, NJ: Scarecrow Press, Inc., 1977.

- ed. Germany and America, 1450-1700. editing of Julius Friedrich Sachse's History of the German Role in the Discovery, Exploration and Settlement of the New World. Bowie MD: Heritage Books, 1991, (originally published 1897).
- "Survival of an Ethnic Community: Cincinnati Germans, 1920-1932." PhD Diss., University of Cincinnati, 1982 .

Trefousse, Hans. "The German-American Immigrants and the Newly Founded Reich." in American and the Germans: An Assessment of a Three Hundred Year History. eds. Frank 
Trommler and Joseph McVeigh, Vol I, 160-175. Philadelphia: University of Pennsylvania Press, 1985.

Trommler, Frank, and Joseph McVeigh, eds. America and the Germans: An Assesement of a Three-Hundred Year History. 2 vols. Philadelphia: University of Pennsylvania Press, 1985.

Vecoli, Rudolph J. "European American: from Immigrants to Ethnics." in The Reinterpretation of American History and Culture. eds. William H. Cartwright and Richard L. Watson, Jr., 81-112. Washington, D.C.: National Council for the Social studies, 1973.

Walker, Mack. German Home Towns: Community, state, and the General Estate, 1648-1871. Ithaca: Cornell University Press, 1971.

- Germany and the Emigration, 1816-1885. Cambridge: Harvard University Press, 1964.

Ward, David. Cities and Immigrants: A Geography of change in Nineteenth-Century America. New York: Oxford University Press, 1971.

"Immigration: Settlement Patterns." in Harvard Encyclopedia of American Ethnic Groups. ed. Stephen Thernstrom, 496-508. Cambridge: Harvard University Prass, 1980.

Warner, $w$ Lloyd and Lew Srole. The Social Systems of American Ethnic Groups. New Haven: Yale University Press, 1947.

Warner, Jr., Sam Bass. Streetcar Suburbs: The Process of Growth in Boston. Cambridge, MA: Harvard University Press, 1978, 2nd. ed.

Weaver, Alice 0. "A German-American Household in Early Toledo, 105 oliver Street." Northern Ohio Quarterly. 54 (1982): 103-116.

Wheeler, Thomas. The Immigrant Experience: The Anquish of Becoming an American. New York: Dial Press, 1971.

Wiesinger, Gerhard. "Die Deutsche Einwandererkolonie von Holyoke, Massachusetts, 1865-1920." PhD Diss.. Universitat Munchen, 1990. To appear under the same title, stuttgart: Franz steiner Verlag in 1994.

Wilk, Gerard H. "Yorkville, Twenty Years After: The Brown Shirts are Gone." Commentary. 17 (January 1954): 41-48. 
Williams, David. "Without Understanding: The FBI and Political Survelliance, 1908-1941." PhD Diss., University of New Hampshire, 1981.

Winkel, Peter. "Skepticism turns to Enthusiasm: Seventeen Letters Written by a German Immigrant in New Jersey to His Father in Hesse-Darmstadt between 2852 and $1859 . "$ Yearbook for German-American studies. 24 (1989): 41-58.

wirsing, Dale. Builders, Brewers, and Burghers: Germans of Washington State. Washington State American Revolution Bicentennial Commission, 1977.

Wittke, Carl. Against the Current: The Life of Karl Heinzen (1809-80). Chicago: University of Chicago Press, 1945.

- German-Americans and the World War. Columbus, Ohio: The Ohio state Archaeological and Historical Society, 1936.

- The German Lanquage Press in America. Lexington: University of Kentucky Press, 1957.

- The Irish in America. Baton Rouge: Louisiana State University Press, 1956.

- "Ohio's Germans, 1840-1875." The Ohio Historical Quarterly. 66 (October 1959): 339-354.

- Refugees of Revolution: The Germen Forty-Eighters in America. Philadelphia: University of Pennsylvania Press, 1952.

- We Who Built America: The Saga of the Immigrant. New York: Prentice-Hall, 1940.

Wood, Virginia. Immigrant Arrivals: A Guide to Published Sources. Washington, DC: Library of Congress, 1988.

Yox, Andrew P. "The Decline of the German-American Community in Buffalo, New York, 1855-1925." Phd Diss., University of Chicago, 1985

zeydel, Edwin H. The Teaching of German in the United States from Colonial Times through World War I." in Teaching German in America: prolegomena to a History. eds. David $P$ Benseler, WaIter F.W. Lohnes, and Valters Nollendorf, 15-64. Madison: University of Wisconsin Press, 1988.

zieren, Gregory R. "Late Nineteenth-Century Forces of Assimilation on Eerman Immigrants: The Views of 
Economist August Sartorius von Waltershausen." Yearbook of German-American studies. 21 (1986): 127-36.

zucker, A.E., ed. The Forty-Eighters: Political Refugees of the Revolution of 1848. New York: Columbia University Press, 1950.

Zunz, Oliver. "American History and the Changing Meaning of Assimilation." Journal of American Ethnic History.

4 (Spring 1985): 53-72.

- The Changing Face of Inequality: Urbanization, Industrial Development, and Immiarants in Detroit, $1880-$ 1920. Chicago: University of Chicago Press, 1982.

- "The organization of the American City in the Late Nineteenth Century: Ethnic structure and spatial Arrangement in Detroit." Journal of Urban History. 3 (August 1977): 443-466.

ORAL HISTORIES AND INTERVIEWS

Immigrant City Archives, Lawrence, MA. Oral History Project. Hilda Miller Keogh, Number 54, May 3, 1979 Dorothy Seubert, Number 77, April 3, 1984 Helen Meinhardt, Number 179, September 9, 1980 George Bayreuther, Number 316, November 22, 1993

Interviews conducted by author.

Erwin Boetcher, Manchester, April 18, 1986 Dorothy C. Emmert, Lawrence, November, 16, 1993

Julius R. Emmert, Lawrence, November 16, 1993

Julius W. Emmert, Lawrence, November 16, 1993 March 17, 1994

Agnes Hecker, Manchester, April 18, 1986

Helen L. Paul, Manchester, December 18, 1991

Herbert W. Paul, Sr., Manchester, December 18, 1991

Margaurite Sandmann, Manchester, March 12, 1986

June 10, 1991

Anna (Sch Unland) Van Loan, Manchester, January 21, 1992 Elsie Zindt, Manchester, March 17, 1986

And several others who wished to remain anonymous. 